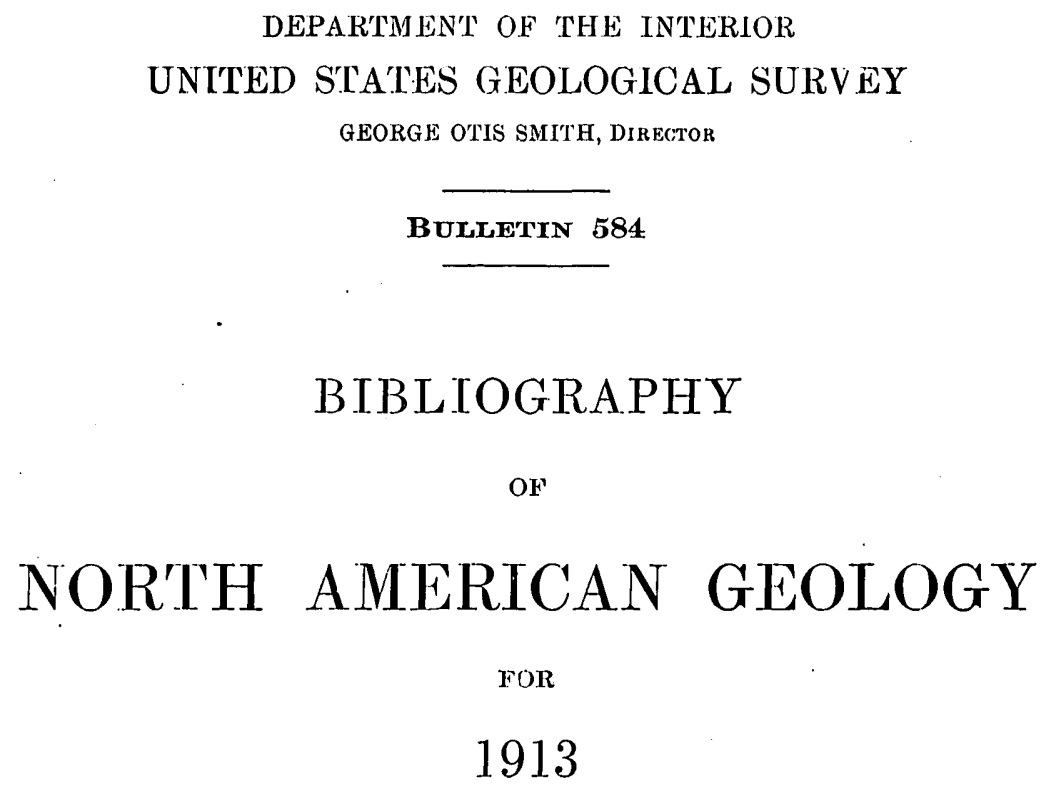

WITH SUBJEC'T INDEX

BY

JOHN M. NICKLES

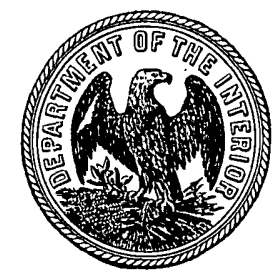

WASH I NGTON

GOVERNMENT PRINTING OFFICE

- 1914 



\section{CONTENTS.}

Introduction _....... 5

Serials examined

Bibliography _............ 13

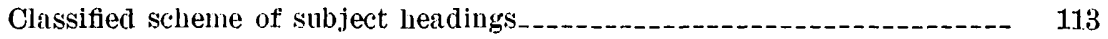

Index _... 11 j

Lists _._.

Chemical analyses_._-_._- 162

Minerals described _......._. 163

Rocks described_._- 164

Geologic formations described__-_._- 165 



\title{
BIBLIOGRAPHY OF NORTH AMERICAN GEOLOGY FOR 1913, WITH SUBJECT INDEX.
}

\author{
By John M. NickLes.
}

\section{INTRODUCTION:}

The bibliography of North American geology, including paleontology, petrology, and mineralogy, for the year 1913 follows the plan and arrangement of its immediate predecessors, the bibliographies for 1906-7, 1908, 1909, 1910, 1911, and 1912 (Bulletins 372, 409, $444,495,524$, and 545 of the U. S. Geological Survey). It includes publications bearing on the geology of the Continent of North America and adjoining islands, also Panama and the Hawaiian Islands. Papers by American writers on the geology of other parts of the world are not included. Textbooks and papers general in character by American authors are included; those by foreign authors are excluded unless they appear in American publications.

As heretofore, the papers, with full title and medium of publication and explanatory note when the title is not fully self-explanatory, are listed under the authors, arranged in alphabetic order. The author list is followed by an index to the literature listed. In this index the entries in one alphabet are of three kinds-first, subject, with various subdivisions, to enable the specialist to ascertain readily all the papers bearing on a particular subject or area; second, titles of papers, many of them abbreviated or inverted, under their leading words; and third, cross references, which have been freely used to avoid too much repetition. The subjects have been printed in black-faced type, the titles of papers and cross references in ordinary type. As it may not be always obvious which subject headings have been adopted, a classified scheme of those used immediately precedes the index.

Miss Isabel P. Evans has given efficient assistance in the work.

The bibliography of North American geology is comprised in the following bulletins of the United States Geological Survey: No. 127 (1732-1892) ; Nos. 188 and 189 (1892-1900) ; No. 301 (1901-1905); No. 372 (1906-7) ; No. 409 (1908) ; No. 444 (1909) ; No. 495 (1910); No. 524 (1911); No. 545 (1912); and No. 584 (1913). 



\section{SERIALS EXAMINED.}

Academy of Natural Sciences of Philadelphia: Proceedings, vol, 64, pt. 3, vol. 65 , pts. 1., 2 ; Journal, 2 d ser., vol. 16, pt. 1. Philadelphia, Pir.

Academy of Science of St. Louis: Transactions, vol, 21, no. 4 ; vol. 22, nos. 1-4. St. Louis, Mo.

Alabama Geological Survey: Bulletin, no. 13; Monograph, no. 8. Montgomery, Alı.

American Academy of Arts and Sciences: Proceedings, vol, 48, nos. 14-20, rol. 49, nos. 1-10. Boston, Mass.

American Geographical Society: Bulletin, vol. 45. New York.

American Institute of Mining Engineers: Bulletin, nos. 73-84; Transactions, vols. 43, 44. New York.

American Journal of Science, 4th ser., vols. 35, 36. New Haven, Conn.

American Mining Congress: Papers and Addresses, 15th Ann. Session; Bulletin, vol. 16 , nos. $1-3$.

American Museum of Natural History : Bulletin, vol. 32 ; Journal, vol. 13 . New York.

American Naturalist, vol. 47. New York.

American Philosophical Society: Proceedings, vol. 52. Philadelphia, Pi.

American Year Book for 1912. New York.

Annales de Paléontologie, t. 8. Paris, France.

Annales des Mines, $11^{\text {e }}$ sér., t. 3, 4. Paris, France.

Annals ind Magizine of Natural History, Sth ser., vols. 11, 12. Iondon.

Appalachia, vol. 13, no. 1. Boston, Mass.

Association of American Geographers: Aunals, vol. 2. Albany, N. Y.

Association of Engineering Societies: Journal, vols. 50, 51. Boston, Mass.

Beitrüige zur Geophysik, Bd. 12, H. 2-4, Bd. 13, H. 1, 2. Leipzig.

Bernice Pauahi Bishop Museum: Occasional Papers, vol. 5, nos. 3, 4. Honolulu, Hawaiian Islands.

Botanical Gazette, vols. 55, 56. Chicago, Ill.

British Columbia, Bureau of Mines: Annual Report of the Minister of Mines for 1912. Victoria, B. C.

California Academy of Sciences: Proceedings, 4th ser., vol. 2, pp. 1-202, vol. 3, pp. 265-454. San Francisco, Cal.

California State Mining Bureau: Bulletin, no. 63. San Francisco, Cal.

Californịa, University of, Department of Geology: Bulletin, vol. 7, nos. 9-23. Seismographic Stations: Bulletin, no. 4. Publications in Geography, vol. 1, nos. 1, 2. Berkeley, Cal.

Canada, Geological Survey: Memoirs, nos. 20, 23, 26, 29, 30, 33, 37. Victoria Memorial Museum: Bulletin, no. 1. Ottawa, Ont.

Canada, Department of Mines, Mines Branch : Summary Report for 1912; and miscellaneous publications. Ottawa, Ont.

Canadian Institute: Transactions, vol. 10, pt. 1. Toronto, Ont.

Canadian Mining Institute: Quarterly Bulletin, no. 22; Journal, General Index, vols. 1-10. Ottawa, Ont.

Canadian Mining Journal, vol, 34. Toronto and Montreal, Canada. 
Canadian Peat Society: Journal, vol. 2, nos. 1-4. Ottawa, Ont.

Carnegie Institution of Washington: Yearbook no. 11, for 1912. Washington, D. C.

Carnegie Museum: Annals, vol. S, nos. 3-4;-Memoirs, vol. 6, nos. 1-3. Pittsburgh, Pal.

Cassier's Magazine, vol. 43, no. 6, vol. 44, nos. 1-3. New York.

Centralblatt für Mineralogie, Geologie, und Paleontologie, Jahrgang 1913. Stuttgart, Germany.

Coal Age, vols. 3, 4. New York.

Colliery Engineer (continuation of Mines and Minerals), vol. 34, nos. 1-5. Scranton, Pa.

Colorado College Publications: Science series, vol. 12, no. 12. Colorado Springs, Colo.

Colorado Geological Survey : Bulletins 4-5, 6. Denver, Colo.

Colorado School of Mines Magazine, vol. 3; Quarterly, vol. 8, nos. 1-3. Golden, Colo.

Colorado Scientific Society : Proceedings, vol. 10, pp. 211-414. Denver, Colorado.

Colorado, University of: Studies, vol. 10, nos. 1-3. Boulder, Colo.

Connecticut Academy of Arts and Sciences: Transactions, vol. 18, pp. 1-137. New Haven, Conn.

Connecticut State Geological and Natural History Survey: Bulletin, no. 20. Hartford, Conn.

Denison University, Scientific Laboratories: Bulletin, vol. 17, pp. 203-246. Granville, Ohio.

Deutsche geologische Gesellschaft: Zeitschrift, Bd. 64, H. 4, Bd. 65, H. 1-7; Monatsberichte, nos. 1-6. Berlin, Germany.

Economic Geology, vol. 8. Lancaster, Pa.

Elisha Mitchell Scientific Society: Journal, vol. 28, no. 4, vol. 29, nos. 1-2. Chapel Hill, N. C.

Engineering and Mining Journal, vols. 95, 96. New York.

Engineering Association of the South: Proceedings, vol. 24, nos. 1-4. Nashville, Tenn.

Engineering Magazine, vol. 44, nos. 4-6, vol. 45, vol. 46, nos. 1-3. New York.

Engineer's' Club of Philadelphia: Proceedings, vol. 30. Philadelphia, Pa.

Engineer's' Society of Western Pennsylvania: Proceedings, vol. 28, no. 10, vol. 29, nos. 1-9. Pittsburgh, Pa.

Field Museum of Natural History: Geological series, vol. 4, no. 3. Chicago, Ill. Florida State Geological Survey: Fifth Annual Report. Tallahassee, Fla.

Franklin Institute: Journal, vols. 175, 176. Philadelphia, Pa.

Geographical Journal, vols. 41, 42. London.

Geographical Society of Philadelphia : Bulletin, vol. 11. Philadelphia, Pa.

Geological Magazine, new ser., decade 5, vol. 10. London.

Geological Society of America: Bulletin, vol. 24. New York.

Geological Society of London: Quarterly Journal, vol. 69, pts. 1-3. IJondon.

Geologische Rundschau, Bd. 4. Leipzig, Germany.

Geologists' Association, London: Proceedings, vol. 24, pts. 1-5. London.

Georgia Geological Survey: Bulletin, no. 20. Atlanta, Ga.

Harvard College, Museum of Comparative Zoology : Bulletin, vol. 53, no. 10, vol. 54, nos. 16-21, vol. 55, no. 2, vol. 57, no. 2 , vol. 58, no. 1 ; Memoirs, vol. 36, vol. 40 , nos. 6, 7 . Cambridge, Mass.

Illinois State Geological Survey: Bulletin, no. 25. Urbana, Ill.

Illinois State Laboratory of Natural History: Bulletin, vol. 9, arts. 6, 7-\$, 9-12. Urbana, Ill. 
Imperial Darthquake Investigation Committee: Rulletin, vol. 5, nos. 2, 3. Tokyo, Japan.

Indiana Acaldemy of Science: Proceedings for 1912. Indianapolis, Ind.

Institution of Mining and Metallurgy: Bulletin, nos. 104-111. London.

Institution of Mining Lngineers: Transactions, vol. 44, pts. 2-5, vol. 45, pts. 1-7, vol. 46 , pt. 1. Newcastle upon 'Tyne, England.

International Geological Congress, Twelfth Session, Canada: Guide Books, $1-4,5-10$.

Iowa Geological Survey, vol. 22; Bulletin no. 4. Des Moines, Iowa.

Journal of Geography, vol. 11, nos. 5-10, vol. 12, nos. 1-4. Madison, Wis.

.Tournal of Geology, vol. 21. Chicago, Ill.

Kansas, University of: Science Bulletin, vol. 16, nos. 2-7. Lawrence, Kans.

Lake Superior Mining Institute: Proceedings, vol. 18. Ishpeming, Mich.

Maryland Gological Survey: Devonian (2 vols. and atlas). Baltimore, Md.

Mexican Mining Journal, vols. 16, 17. Mexico City, D. F.

Mexico, Instituto Geológico: Boletín, no. 30. Mexico City, D. F.

Michigan Academy of Science: Fourteenth report. Lansing, Mich.

Michigan Geological and Biological Survey: Publication 11 (Geological series 8). Lansing, Mich.

Mineralogical Magazine and Journal of the Mineralogical Society, vol. 16 (nos. 7(6-77), vol. 17 (no. 78). London.

Mines and Methods, vol. 4, nos. 5-10. Salt Take City, Utah.

Mines and Minerals, vol. 33, nos. 6-7 (continued from no. 8 as Colliery Iingineer, vol. 34, nos. 1-5). Scranton, Pa.

Mining and Engineering World, vols. 38, 39. Chicago, Ill.

Mining and Metallurgical Society of America : Bulletin, vol. 6, nos. 2-12. New York.

Mining and Scientific Press, vols. 106, 107. San Frimcisco, Cal

Mining Magazine, vols. 8, 9. London.

Mining Science, vols. 67,68 . Denver, Colo.

Minnesota Academy of Sciences: Bulletin, vol. 5, no. 1. Minneapolis, Minn.

Missouri Bureau of Geology and Mines: Biennial Report for 1911-1912. Jefferson City, Mo.

National Geographic Magazine, vol. 24. Washington, D. C.

Nature, vol. 90 (no. 2253)-vol: 92 (no. 2303). London.

Nautilus, vol. 26, nos. 9-12, vol. 27, nos. 1-8. Philadelphia, Pa.

Nenes Jahrbuch für Mineralogie, etc., 1913; Beilage Band, 35, 36. Stuttgart, Germany.

New Brunswick Natural History Society: Bulletin, no. 30 (vol. 6, pt. 5). St. John, N. B.

New Jersey Geological Survey: Bulletin, nos. \&-11. Trenton, N. J.

New York Academy of Sciences: Annals, vol. 22, pp. 339-423, vol. 23, pp. 1-143. New York.

New York Botanical Garden: Bulletin, vol. 8, no. 29. New York.

New York State Museum: Bulletin, nos. 163, 164, 166, 167; 65th Annual Report, vols. 1-4, and Suppl. I. Albany, N. Y.

North Carolina Geological and Economic Survey: Biennial Report for 1911-1912; Economic Paper, nos. 32, 33. Raleigh, N. C.

Nova Scotia Institute of Science: Proceedings and Transactions, vol. 12, pt. 4. Halifix, N. S.

Ohio Geological Survey: Fourth series, Bulletin 17. Columbus, Ohio.

Ohio Nitturialist, vol. 13, nos. 3-8, vol. 14, nos. 1-2. Columbus, Ohio.

Ohio State Academy of Science: Proceedings, vol. 6, pt. 2. Columbus, Ohio. 
Oklahoma Geological Survey: Bulletin, nos. 10, 11; Circular, nos. 4, 5. Norman, Okla.

Ontario Bureau of Mines: Report, vol. 19, pt. 2, vol. 22, pt. 1 . Toronto. Ont.

Ottawa Naturalist, vol. 26, nos. 10-12, vol. 27, nos. 1-9. Ottawa, Ont.

Oregon State Bureau of Mines: Director's Report for 1911-1912. Corvallis, Oreg.

Palaeontologische Zeitschrift, Bd. 1, H. 1. Berlin, Germany. Stuttgart, Germany.

Paleontographica, Bd. 60 ; Supplement VI, Lief. 1-4.

P'ennsylvania, Topographic and Geologic Survey Commission : Report, 1910-1912. Harrisburg, Pa.

Popular Science Monthly, vols. 82, 83. New York.

Royal Society of Canada: Proceedings and Transactions, 3d ser., vol. 6. Ottawa, Ont.

School of Mines Quarterly, vol. 34, nos. 2-4, vol. 35, no. 1. New York.

Science, new ser., vols. 37, 38. New York.

Science Conspectus, vol. 3, nos. 2-3. Boston, Mass.

Seismological Society of America: Bulletin, vol. 3. Stanford University, Cal.

Sierra Club Bulletin, vol. 9, nos. 1, 2. San Francisco, Cal.

Smitbsonian Institution: Annual Report for 1912, and for 1913; Miscellaneous Collections, vol. 57, nos. 11, 12 , vol. 59, no. 19 , vol. 60 , nos. 18-30, vol. 61 , nos. 1-17, 19-21, vol. 62 , no. 1. Washington, D. C.

Sociedad científica "Antonio Alzate": Memorias y Revista, t. 31., nos. 7-12, t. 32 , nos. 1-8, t. 33, nos. 1-8. Mexico, D. F.

Sociedad Geológica Mexicana: Boletin, t. 8 , pt. 1. Mexico City, D. F.

Società Geologica Italiana: Bolletino, vol. 31, fasc. 3-4, vol. 32, fasc. 3. Rome, Italy.

Sociêté de géographie de Québec: Bulletin, vol. 7. Quebec, Canada.

Société géologique de Belgique: Annales, t. 39, 1. 4, t. 40, 1. 1. 2. L.iége, Belgium.

Southern California Academy of Sciences: Bulletin, vol. 12, nos. 1, 2. Ios Angeles, Cal.

Staten Island Association of Arts and Sciences: Proceedings, vol. 4, pts. 1, 2. Staten Island, N. Y.

'Tennessee State Geological Survey : Bulletin, 1-2; 16; Resources of Tennessee, vol. 3 , nos. 1-4. Nashville, Tenn.

Toronto, University of : Studies, Geological series, no. 8. Toronto, Ont.

Torrey Botanical Club: Bulletin, vol. 40. Lancaster, Pa.

Torreya, vol. 13. Lancaster, Pa.

'Tschermaks mineralogische und petrographische Mitteilungen, N. F., Bd. 31, H. 4-6, Bd. 32, H. 1-3. Vienna, Austria-Hungary.

U. S. Bureau of Mines: Second Annual Report; Bulletin, nos. 14, 22, 45, 48, 51-56, 59, 61-63, 65, 69-71; Technical Papers, nos. 31, 33, 36-38, 40, 41, $43,44,46,48,50-53,55,60$. Washington, D. C.

U. S. Dept. of Agriculture: Field Operations of the Bureau of Soils, Twelfth Report. Washington, D. C.

U. S. Geological Survey : 34th Annual Report; Bulletins 522, 525-539, 542, 545, 555; Water-Supply Papers 292, 297, 300, 302, 303, 305, 307, 308, 310, 313-320, 333, 334, 337; Professional Papers 76, 78-80, 85 A, B; Geologic Atlas of the United States, folios 187-190; Mineral Resources of the United States for 1912. Washington, D. C.

U. S. National Museum : Bulletin, nos. 71, 81; Proceedings, vol. 43, pp. 599-669, vol. 44 , vol. 45 , vol. 46 , pp. $1-443,451-472$. Washington, D. C. 
Virginia Geological Survey: Bulletin, nos. III-A, V, VII, VIII. Charlottesville, Va.

Virginia, University of, Publications: Bulletin of the Philosophical Society, Scientific series, vol. 1, nos. 14-17. Charlottesville, Va.

Wagner Free Institute of Science: Transactions, vol. 7, pt. 2 (pp. 35-45). Philadelphia, Pa.

Washington Academy of Sciences: Journal, vol. 3, nos. 1-20. Washington, D. C. Washington Geological Survey: Bulletin, nos. 8, 12, 16. Olymiaia, Wash.

West Virginia Geological Survey, vol. 5 (A) ; Map (coal, etc.) ; County reportsMarion-Monongalia-Taylor counties; Cabell-Wayne-I.incoln counties. Morgantown, W. Va.

Western Engineering, vols. 2, 3. San Francisco, Cal.

Western Society of Engineers: Journal, vol. 18. Chicago, Ill.

Wisconsin Geological and Natural History Survey: Bulletin, no. 26. Madison, Wis.

Wisconsin Natural History Society: Bulletin, new ser., vol. 11, nos. 1-2. Milwaukee, Wis.

Wyoming [Geological Survey]: Series B, Bulletin, no. 5. Cheyenne, Wyo. Zeitschrift für Gletscherkunde, Bd. 7, H. 2-5, Bd. 8, H. 1. Berlin, Germany. Zeitschrift für Krystallographie, Bd. 52, Bd. 53, H. 1-3. Leipzig, Germany. Zeitschrift fïr praktische Geologie, Jahrgang 21. Berlin, Germany. 



\section{BIBLIOGRAPHY.}

Abbot, C. G.

1. Do volcanic explosions affect our climate?: Nat. Geog. Mag., vol. 24, no. 2, pp. 181-198, 10 figs., February, 1913.

Abbot, C. G., and Fowle, F. E.

2. Volcanoes and climate: Smithsonian Misc. Coll., vol. (60, no. 29, 24 pp., 3 figs., March 2S, 1913.

Includes notes on the eruption of Mount Katmai in Alaska.

Abele, Charles Arthur.

3. Statistics of the mineral production of Alabama for 1911: Alabana Geol. Survey, Bull. no. 13, 64 pp., 1913.

Adams, Frank D.

4. The origin of the deep-seated metamorphism of the pre-Cambrian crystalline schists: Intern. Geol. Cong., XI, Stockholm, 1910, Compt. rend., pp. $563-572,1912$.

5. An experimental investigation into the flow of rocks (with discussion) : Intern. Geol. Cong., XI, Stockholm, 1910, Compt. rend., pp. 911-945, 1 fig., 8 pls., 1912.

6. The Morin anorthosite area [Quebec] : Intern. Geol. Cong., 'Twelfth, Guide Book no. 3 (issued by the Canala Geol. Survey), pp. 5-28, maps, pls., figs., 1913.

7. The Monteregian Hills: Intern. Geol. Cong., 'Twelfth, Guide Book no. 3 (issued by the Cantda Geol. Survey), pp. 29-80, maps, pls., figs., 1913.

Adams, F. D., and Barlow, A. E.

8. Haliburton-Bancroft area of central Ontario: Intern. Geol. Cong., Twelfth, Guide Book no. 2 (issued by the Canada Geol. Survey), pp. 5-98, maps (one in pocket), pls., figs., 1913.

Adams, Geo. I.

9. The terms segment and segmentation in geology: Science, new ser., vol. 37, pp. 177-178, January 31, 1913.

Adams, L. H.

Effect of high pressures on the physical and chemical behavior of solid substances. See Johnston and Adams, no. 565.

Ahlburg, Joh.

10. Die geologische Karte der Welt: Der Geologe, no. 11, pp. 195-202, 5 figs., November, 1913.

Alden, Wm. C., and Stebinger, Eugene.

11. Pre-Wisconsin glacial drift in the region of Glacier National Park, Montana: Geol. Soc. America, Bull., vol. 24, no. 4, pp. 529-572, 4 pls. (incl. map), 8 figs., November 10, 1913. 
Alfaro, Anastasio.

12. Rocas volcánicas de Costa Rica: Boletin de Fomento, Costa Rica, año 3, no. 8, pp. 549-555, 4 figs., August, 1913.

Describes the occurrence of volcanic rocks at several localities in Costa Rica.

Allan, John A.

13. Rocky Mountains, Bankhead to Golden: Intern. Geol. Cong., Twelfth, Guide Book no. 8 (issued by the Canada Geol. Survey), pp. 167201, maps, pls., figs., 1913.

Allen, E. T., and Crenshaw, J. L.

14. The sulphides of zinc, cadmium, and mercury; their crystalline forms and genetic conditions; microscopic study by H. E. Merwin (abstract) : Washington Acad. Sci., Jour., vol. 3, no. 4, pp. 114-115, February 19, 1913.

Allen, Glover M.

15. A new Mylodon: Harvard Coll., Mus. Comp. Zool., Mem., vol. 40, no. 7, pp. 319-346, 4 pls., September, 1913.

Describes Mylodon garmani n. sp. from the Pleistocene of the Niobrara River, Nebraska.

Allen, R. C; and Ruthven, A. G.

16. Progress of the geological and biological survey of Michigan: Michigan Acad. Sci., 14th Rept., pp. 33-36, 1912.

Anderson, F. M. See Martin, no. 749, and Taff, no. 1144.

Anderson, Robert.

17. Some suggestions for genèral field work: Econ. Geology, vol. 8, no. 3, pp. 289-291, 1913.

Anspach, E. V.

A preliminary study of the waters of the Jemez Platean, New Mexico. See Kelly and Anspach, no. 586.

Arnold, Ralph, and Hannibal, Harold.

18. The marine Tertiary stratigraphy of the north Pacific const of America : Am. Philos. Soc., Proc., vol. 52, pp. 559-605, 12 pls., NovemberDecember, 1913.

Ashley, George H., and Campbell, M. R.

19. Geologic structure of the Punxsutawney, Curwensville, Houtzdale, Barnesboro, and Patton quadrangles, central Pennsylvania: U. S. Geol. Survey, Bull. 531, pp. 69-89, 2 pls. (map and sections), 1 fig., 1913.

Atlin District [British Columbia] Board of Trade.

20. The gold fields of Atlin, B. C., Canada. $36 \mathrm{pp}$., 1 map. London, Alexander Moring, 1913.

Babb, Cyrus C.

21. Bibliography of Maine geology: Maine, State Water Storage Comm., 3d Ann. Rept., pp. 10, 185-242, 1913.

Bagg, Rufus Mather.

22. The discovery of pyrrhotite in Wisconsin, with a discussion of its probable origin by magmatic differentiation: Econ. Geology, vol. S. no. 4, pp. 369-372, 1 fig., 1913. 
Baker, Charles Laurence.

23. The nature of the later deformations in certain ranges of the Great Basin : Jour. Geology, vol. 21, no. 3, pp. 273-278, 1913.

Baker, Frank Collins.

24. Interglacial records in New York: Science, new ser., vol. 37, pp. 523-524, Apr. 4, 1913.

25. Notes on postglacial Mollusca; I, Emmet County, Michigan; II, Waukesha County, Wisconsin: Nautilus, vol. 27, pp. 7-8, 68, May and October, 1913.

26. Interglacial mollusks from South Dakota: Science, new ser., vol. 38, pp. 858-859, December 12, 1913.

Baker, Howard $\mathrm{B}$.

27. The origin of continental forms; II: Michigan Acad. Sci., 14th Rept., pp. 116-141, 1912.

Baker, M. B.

28. Mineral deposits near' Kingston, Ontario: Intern. Geol. Cong., Twelfth, Guide Book no. 2 (issued by the Canada Geol. Survey), 111. 11.9139, 1 map, 1 figr., 2 pls., 1913.

29. Clay deposits and works near Toronto: Intern. Geol. Cong., Twelfth, Guide Book no. 6 (issued by the Ontario Bur. Mines), pp. 49-53, 1913.

Ball, Lionel C.

30. Field and office methods in the preparation of geological reports; some notes on equipment: Econ. Geology, vol. 8, no. 4, pp. 382-383, 1913.

Ball, Sydney H.

31. Sandstone copper deposits at Bent, New Mexico: Min. and Sci. Press, vol. 107, pp. 132-136, 1 map, 2 figs., July 26, 1913.

Bancroft, George J.

32. The formation and enrichment of ore-bearing veins [reprinted from Am. Inst. Min. Eng., 'Trans., vol. 38, pp. 245-26s, 1908, and vol. 40, pp. 809-817, 1910]. In Emmons, S. F.,. Ore deposits, pp. 696-728, published by the American Institute of Mining Engineers, New York, 1913.

33. 'The exodus of ore deposits: Min. Sci., vol. 67, pp. 181-183, April, 1913.

34. The geology of the Moffat tunnel, Colorado: Min. Sci., vol. 68, pp 23-26, 2 figs., July, 1913.

Bancroft, J. Austen.

35. Geology of the coast and islands between the Strait of Georgia and Queen Charlotte Sound, British Columbia: Canada, Geol. Survey, Meur. no. 23, 146 pp., 17 pls., 5 figs., 1 diagr., 1 map, 1913.

36. A report on the geology and natural resources of certain portions of the drainage basins of the Harricanaw and Nottaway rivers, to the north of the National Transcontinental Railway in northwestern Quebec: Quebec (Province), Dept. Colonization, Mines, and Fisheries, Mines Branch, Report on Mining Operations, 1912, pp. 131191, 5 pls., geol. map, 1913.

37. Report on the geology and natural resources of an area embracing the headwaters of the Harricanaw River, northwestern Quebec: Quebec (Province), Dept. Colonization, Mines, and Fisheries, Mines Branch, Rept. on Mining Operations, 1912, pp. 199-236, 1 1)., 1 fig., geol. map, 1913. 
Barck, C.

38. 'Caves: Mazama, vol. 4, no. 2, pp. 61-69, December, 1913.

Discusses the occurrence and mode of formation of different classes of caves.

Bard, D. C., and Gidel, M. H.

39. Mineral associations at Butte, Mont. : Am. Inst. Min. Eng., Bull. no. 80, pp. 1627-1631, August, 1913.

Barker, E. Eugene.

40. Glacial potholes at Crown Point, New York: Jour. Geology, vol. 21, no. 5, pp. 459-464, 4 figs., 1913.

Barlow, A. E.

41. The nepheline and alkali syenites of the Port Coldwell area: Intern. Geol. Cong., Twelfth, Guide Book no. 8 (issued by the Canada Geol. Survey), pp. 16-24, 1913.

Haliburton-Bancroft area of central Ontario. See Adams and Barlow, no. 8 .

Barnes, Corbin, and Byler, E. A.

42. Relation of faulting and mineralization in Goldfield [Nevada] : Min. and Sci. Press, vol. 107, pp. 59-60, 2 figs., July 12, 1913.

Barnett, V. H.

43. Field methods of geologic mapping in public land states of the west: Econ. Geology, vol. 8, no. 3, pp. 272-279, text fig. 23, 1913.

Barrell, Joseph.

44. Field and office methods in the preparation of geologic reports; measurements by compass, pace, and aneroid: Econ. Geology, vol. 8, no. 7, pp. 691-700, October, 1913.

45. The Upper Devonian delta of the Appalachian geosyncline; Part I, the delta and its relations to the interior sea: Am. Jour. Sci., 4th ser., rol. 36, pp. 429-472, 4 figs., November, 1913.

46. Piedmont terraces of the northern Appalachians and their mode of origin (abstract) : Geol. Soc. America, Bull., vol. 24, no. 4, pp. 6SS-690, December 23, 1913.

47. Post-Jurassic history of the northern Appalachians (abstract, with discussion by D. W. Johnson, W. M. Davis, N. H. Darton, and J. Barrell) : Geol. Soc. America, Bull., vol. 24, no. 4, pp. 690-696, December 23, 1913.

See also Grabau, no. 431.

Barrow, Albert L.

48. Preliminary inquiry into the geological significance of rock-boring shells (abstract) : Geol. Soc. America, Bull., vol. 24, no. 1, pp. 130-131, March 24, 1913.

Barrows, w. A., jr.

The iron ores of the South Range of the Cuyuna district, Minnesota. See Zaipffe and Barrows, no. 1351.

Barton, Donald C.

49. A new genus of the Cheiruridie, with descriptions of some new species: Harvard Coll., Mus. Comp. Zoül., Bull., vol. 54, no. 21. 11. 547-5506, 1 pl., November, 1913.

$A$ revision of the American species of Ceraurus. See Raymond and Barton, no. 959. 
Bassler, R. S.

50. Proceedings of the fourth annuil meeting of the Paleontological Society, held at New Haven, Connecticut, December 30 and 31, 1912: Geol. Soc. America, Bull., vol. 24, no. 1, pp. 99-126, March 24, 1913.

51: Notes on an unusually fine slab of fossil crinoids: U. S. Nat. Mus., Proc., vol. 46, pp. 57-59, 2 pls., November 29, 1913.

Systematic paleontology of the Lower Devonian deposits of Maryland: Bryozoa, Ostracodi. See Ulrich and Bassler, no. 1190.

Systematic paleontology of the Middle Devonian deposits of Maryland; Bryozoal. See Ulrich and Bassler, no. 1191.

Bastin, Edson $\mathbf{S}$.

52. Metasomatism in downward sulphide enrichment: Econ. Geology, vol. 8, no. 1, pp. 51-63, 5 figs., January, 1913.

53. Secondary enrichment in silver (abstract) : Washington Acad. Sci., Jour., vol. 3, no. 2, p. 52, Jauuiry 19, 1913.

54. Chemical composition as a criterion in identifying metamorphosed sediments: Jour. Geology, vol. 21, no. 3, pp. 193-201, 1913.

55. Graphite: U. S. Geol. Survey, Mineral Resources, 1912, pt. 2, pp. 1061$1069,1913$.

The rồle of certain metallic minerals in precipitating silver and gold. See Palmer and Bastin, no. 877.

Metallic minerals as precipitants of silver and gold. See Palmer and Bastin, no. 878.

Bastin, Edson S., and Williams, Henry S.

56. Geology of the Eastport quadrangle: Maine, State Water Storage Comm., 3d Ann. Rept., pp. 166-169, 1913.

Bather, F. A.

57. I, The Trenton crinoid Ottawacrinus W. R. Billings; II, Note on Merocrinus Walcott: Canada Geol. Survey, Victoria Meinorial Mus., Bull.'no. 1, pp. 1-14, 1 pl., October 23, 1913.

Beal, Carl Hugh.

Supplementary notes on fossil sharks. See Jordan and Beal, no. 574.

Bean, E. F.

A minual of physical geography excursions. See Martin, Williams, and Bean, no. 762 .

Beck, $\dot{R}$.

58. Microscopy in economic geology: Eng. and Min. Jour., vol. 95, no. 22, pp. 1087-1089, May 31, 1913.

Becker, George F.

59. Biographical notice of Samuel Franklin Emmons [reprinted from Am. Inst. Min. Eng., Trans., vol. 42, pp. 643-661, 1 pl. (port.), 1912]. In Emmons, S. F., Ore deposits, pp. xxix-xlvii, published by the American Institute of Mining Engineers, New York, 1913.

60. The torsional theory of joints (with discussion by H. M. Howe, R. W. Raymond, G. F. Becker, and C. R. Boyd) [reprinted from Am. Inst. Min. Eng., Trans., vol. 24, pp. 130-138, 863-867, 1895\%. In Emmons, S. F., Ore deposits, pp. 92-104, 1 fig., published by the American Institute of Mining Engineers, New York, 1913.

$38416^{\circ}-$ Bull. $584-14-2$ 
Beede, J. W.

61. Fossil fauna, Conemaugh series [West Virginia]: West Virginia Geol. Survey, Marion, Monongalia, and Taylor. counties, pp. 322-324, 1913.

A list of species occurring in the Ames, Pine Creek, and Brush Creek limestones in the Carboniferous of West Virginia.

Bell, J. M.

62. The occurrence of gold in Ontario (discussion): Inst. Min. and Met., Bull. no. 111, pp. 45-46, December 11, 1913.

Bell, Robert N.

63. Fourteenth annual report of the mining industry of Idaho for the year

1912: Idaho, State Inspector of Mines, 190 pp., illus. [1913].

Includes notes on the occurrence of ore deposits and of the rare metals.

Bell, W. A.

64. Excursion in eastern Quebec and the maritime provinces; HortonWindsor (pp. 136-144, 146-151); the Joggins Carboniferous section (pp. 326-346) : Intern. Geol. Cong., Twelfth, Guide Book no. 1 (issued by the Canada Geol. Survey) 1913.

Bement, A.

65. The Illinois coal fields: Coal Age, vol. 3, 11. 15, pp. 558-562, 2 maps, April 12, 1913.

Bensley, B. A.

66. A Cervalces antler from the Toronto interglacial: Toronto, Univ., Studies, Geol. ser., no. 8, 3 pp., 1 fig., 1913.

Describes Cervalces borealis n. sp.

Berkey, Charles P.

67. Field and office methods in the preparation of geologic reports; objects and methods of petrographic description: Econ: Geology, vol. S, no. 7, pp. 700-711, October, 1913.

68. Petrographic range of road building material: School of Mines Quarterly, vol. 35, no. 1, pp. 22-27, November, 1913.

69. Is there fault control of the Hudson River course? (abstract) : New York Acad. Sci., Annals, vol. 22, p. 351, April 20, 1913.

70. Geological light from the Catskill aqueduct (with discussion by J. W. Spencer) : Geol. Soc. America, Bull., vol. 24, no. 4, p. 711, December $23,1913$.

71. Objects and methods of petrographic description (abstract) : Geol. Soc. America, Bull., vol. 24, no. 4, p. 719, December 23, 1913.

Berry, Edward W.

72. A fossil flower from the Eocene: U. S. Nat. Mus., Proc., vol. 45, pp. 261263, 1 pl., 1 fig.; June 13, 1913.

Describes Combretanthites eocenica $\mathbf{n}$. gen. and $\mathbf{n}$. sp. from the Wilcox group in Fayette County, Tennessee.

73. Contributions to the Mesozoic flora of the Atlantic Coastal Plain: IX, Alabama: Torrey Bot. Club, Bull., vol. 40, no. 10, pp. 56i-574, October, 1913.

74. Status of the study of the fossil floras of the Atlantic Coastal Plain (abstract) : Geol. Soc. America, Bull., vol. 24, no. 1, p. 114, March 24, 1913. 
Billingsley, Paul.

75. The Southern Cross mine, Georgetown, Montana: Am. Inst. Min. Wng., Bull. no. 81, pp. 22\$9-2297, 3 figs., September, 1913; Min. and Eng. World, vol. 39, pp. 781-784, 3 figs., November 1, 1913.

Describes the general geology of the district and the character. occurrence, structural relations, and origin of the ore bodies mined for their gold content.

Blackwelder, Eliot.

76. New or little known Paleozoic faunas from Wyoming and Idaho: Am. Jour. Sci., 4th ser., vol. 36, pp. 174-179, August, 1913.

77. Field and office methods in the preparation of geologic reports; a modification of the Walcott method of measuring stratigraphic sections: Econ. Geology, yol. 8, no. 5, pp. 489-492, 2 figs., 1913.

78. Origin of the Bighorn dolomite of Wyoming: Geol. Soc. America, Bull., vol. 24 , no. 4, pp. 607-624, 8 pls., 1 fig., Dec. 22, 1913.

79. Coralline algæe in an Ordovician dolomite (abstract): Geol. Soc. America, Bull., vol. 24, no. 1, p. 115, March 24, 1913.

See also Richards and Mansfield, no. 974.

Blair, A. W., and Jenning, Henry.

80. The mechanical and chemical composition of the soils of the Sussex area, New Jersey: New Jersey Geol. Survey, Bull. 10, 110 pp., 2 pls., 1913.

Bliss, Ele:tnora F.

81. Glaucophane from eastern Penusylvanial: Am. Mus. Nat. Hist., Bull., vol. 32 , pp. 517-526, 5 figs., 1913.

Bond, Josiah.

82. Influence of joints on the.location of ore shoots: Mexican Min. Jour.. vol. 16, no. 1, pp. 19-21, \& figs., January, 1913.

Includes notes on the geology of First Watchung Mountain, New Jersey, and the genesis of the copper ores there.

Bonillas, Y. S.

83. Algunas aplicaciones prúcticas de lit geologia (abstract): Soc. Geol. Mexicana, Bol., t. 8, pt. 1, pp. iv-v, 1912.

Bonillas, Y. S., and Urbina, I'.

84. Informe acerca de los recursos naturales de la parte norte de la Baja California, especialmente del Delta del Río Colorado: Mexico, Inst. Geol., Parerg., t. 4, nos. 2-10, pp. 161-235, 24 pls., 1913.

Includes notes on the geology and mineral resources on the northern part of the peninsula of Lower California.

Böse, Emilio.

85. Algunas faunas del Cretacico superior de Coahuila y regiones limitrofes: Mexico, Inst. Geol., Boletín núm. 30, 56 pp., 8 pls., 1913.

Describes Cretaceous Mollusca from various localities, chiefly from the State of Coahuila, Mexico.

Böse, E., and Wittich, E.

86. Informe relativo á la exploración de la región norte de la costa occidental de la Baja California: Mexico, Inst. Geol., Parerg., t. 4, nos. 2-10, pp. 307-529, 25 pls., 1913.

Includes notes on the geology and mineral resources of the north. western part of Lower California. 
Bosworth, T. O.

87. Notes on the semiarid conditions in a part of southern Texas: Geol. Mag., new ser., dec. 5, vol. 10, no. 11, pp. 481-485, 2 pls., November, 1913.

Botsford, C. A.

88. A possible Arizona oil field : Western Eng., vol. 3, no. 3, pp. 187-189, 2 figs., September, 1913.

Describes the geologic structure of the Tonto Basin oil district.

89. Disseminated replacement copper deposits: Eng. and Min. Jour., vol. 95, no. 12 , pp. $620-622$, March 22, 1913.

\section{Boutwell, John Mason.}

90. Geology and ore deposits of the Park City district, Utah (abstract) : Washington Acad. Sci., Jour., vol. 3, no. 16, pp. 445-447. October $4,1913$.

Bowen, C. F.

91. Coal at Horseshoe Bend and Jerusalem Valley, Boise County, Idaho: U. S. Geol. Survey, Bull. 531, pp. 245-251, 1 pl. (map), 1 fig., 1913.

Describes the stratigraphy and structure of the area, the occurrence and extent of the coal beds, and the character of the coal.

92. Lignite in the Goose Creek district, Cassia County, Idaho; U. S. Geol.

Survey, Bull. 531, pp. 252-262, 1 pl. (map and sections), 1913.

Describes the stratigraphy of the area and the occurrence and character of the coal beds.

Bowen, N. L.

93. Columnar sections, Coast Range, eastern part, Lytton to Hope, western part, Hope to Vancouver [British Columbia]: Intern. Geol. Cong., Twelfth, Guide Book no. 8 (issued by the Canada Geol. Survey), pp. 257-258, 1913.

94. The melting phenomena of the plagioclase feldspars: Am. Jour. Sci., 4th ser., vol. 35, pp. 577-599, 3 figs., June, 1913.

95. The order of crystallization in igneous rocks: Jour. Geology, vol. 21, no. 5, pp. 399-401, 1913.

Bradley, H. W.

On solid solution in minerals; III, The constant composition of albite. See Foote and Bradley, no. 380.

On solid solution in minerals; IV, The composition of amorphous minerals as illustrated by chryscolla. See Foote and Bradley, no. 381.

Bradley, P. R.

96. Pyrites deposit in Plumas County, California: Min. and Metal. Soc. America, Bull. no. 65, vol. 6, pp. 276-278, October 31, 1913.

Bradley, W. M.

Pyroxmangite, a new member of the pyroxene group and its alteration. product, skemmatite. See Ford and Bradley, no. 383.

On hetærolite from Leadville, Colorado. See Ford and Bradley, no. 384.

Branner, J. C.

97. Warthquakes and structural engineering: Seism. Soc. America, Bull., vol. 3, no. 1, pp. 1-5, March, 1913.

98. Influence of wind on the accumulation of oil-bearing rocks (abstract) : Geol. Soc. America, Bull., vol. 24, no. 1, pp. 94-95, March 24, 1913. 
Branson, E. B.

99. Devonian fishes of Missouri (abstract) : Geol. Soc. America, Bull., vol. 24, no. 1, p. 119, March 24, 1913.

100. A four mile section along the Missouri River south of Colnmbia, Missouri (abstract) : Science, new ser., vol. 37, p. 459, Murch 21, 1913.

Bretz; J. Harlen.

101. Glaciation of the Puget Sound region: Washington Geol. Survey, Bull. no. 8,244 pp., 24 pls., 27 figs., 1913.

\section{Brinker, Arthur C.}

102. Geology at Santa Eulalia, Chihuahua: Min. and Sci. Press, vol. 106, pp. 895-896, 1 fig., June 14, 1913.

Describes the character and structural relations of the ore bodies.

\section{Brinsmade, R. B.}

103. The copper mines of the Sierra Magistral [Puebla, Mexico]: Mexican Min. Jour., vol. 17, no. 2, pp. 394-397, 5 fgs.., August, 1913.

\section{British Columbia.}

Annual report of the minister of mines for the year ending 31st December, 1912, being an account of mining operations for gold, coal, etc., in the Province of British Columbia. Victoria, B. C., 1913. See Robertson, no. 986.

Broili, F.

104. Über zwei Stegocephalenreste aus dem texanischen Perm: Neues Jinhrb., Bd. 1, H. 2, pp. 96-100, 1 pl., 1913.

Describes two new Stegocephala from the Permian of Texas.

\section{Brokaw, Albert D.}

105. The secondary precipitation of gold in ore bodies: Jour. Geology, vol. 21, no. 3, pp. 251-267, 3 figs., 1913.

\section{Brooks, Alfred H.}

106. A description of methods of placer mining: U. S. Geol. Survey, WaterSupply Paper 314, pp. 269-303, 9 pls., 3 figs., 1913.

107. Mineral resources of Alaska, 1912; preface and administrative report: U. S. Geol. Survey, Bull. 542, pp. 5-17, 1913.

108. Mineral resources of Alaska; the mining industry in 1912: U. S. Geol. Survey, Bull. 542, pp. 18-51, 1 map, 1913.

Applied geology: Smithsonian Inst., Ann. Rept. for 1912, pp. 329-352, 3 figs., 1913. Reprinted from Washington Acad. Sci., Jour., vol. 2, pp. 19-48, 1912.

Brooks, Alfred H., and others.

109. Mineral resources of Alaska; report on progress of investigations in 1912: U. S. Geol. Survey, Bull. 542, 308 pp., 7 figs., 10 pls., 1913.

Brooks, Alfred H., and Martin, George C.

110. The coal resources of Alaska: The Coal Resources of the World, XII Intern. Geol. Cong., Canada, 1913, vol. 1, pp. lxiv-1xv, vol. 2, pp. 541-552, 1. nig. (map), 1913. 
Broom, Robert.

111. On the squamosal and related bones in the mosasaurs and lizards: Am. Mus. Nat. Hist., Bull., vol. 32, pp. 507-508, 2 figs., 1913.

112. On the structure and affinities of Bolosaurus: Am. Mus. Nat. Hist., Bull., vol. 32, pp. 509-516, 5 figs., 1913.

113. On the cotylosaurian genus Pantylus Cope: Am. Mus. Nat. Hist., Bull., vol. 32, pp. 527-532, 4 figs., 1.913.

114. Studies on the Permian temnospondylous stegocephalians of North America : Am.. Mus. Nat. Hist., Bull., vol. 32, pp. 563-595, 21. figs., 1913.

Brown, Amos P., and Pilsbry, Henry A.

115. Fauna of the Gatun formation, Isthmus of Panama, II : Acad. Nat. Sci. Philadelphia, Proc., vol. 64, pt. 3, pp. 509-519, 5 pls., 2 figs., 1913.

116. Two collections of Pleistocene fossils from the Isthmus of Panama: Acad. Nat. Sci. Philadelphia, Proc., vol. 65, pt. 2, pp. 493-500, 3 figs., 1913.

Brown, Barnum.

117. A new crested dinosaur: Am. Mus. Jour., vol. 13, no. 3, pp. 139-144, 7 figs., March, 1913.

Describes the occurrence of fossil dinosaurs in Alberta.

118. Some Cuban fossils; a hot spring yields up the bones of animals that lived before the advent of man: Am. Mus. Jour., vol. 13, no. 5, pp. 221-228, 12 figs., May, 1913.

119. The skeleton of Saurolophus, a crested duck-billed dinosaur from the Edmonton Cretaceous: Am. Mus. Nat. Hist., Bull., vol. 32, pp. 387393, 2 pls., 1 fig., 1913.

120. A new trachodont dinosaur, Hypacrosaurus, from the Edmonton Cretaceous of Alberta: Am. Mus. Nat. Hist., Bull., vol. 32, pp. 395406, 8 figs., 1913.

121. A new plesiosaur, Leurospondylus, from the Edmonton Cretaceous of Alberta: Am. Mus. Nat. Hist., Bull., vol. 32, pp. 605-615, 7 figs., 1913.

122. The manus of trachodont dinosiurs: Science, new ser., vol. 38, pp. 926927, December 26, 1913.

Brown, Calvin $\mathrm{S}$.

123. The petrified forest of Mississippi : Pop. Sci. Monthly, vol. 83, pp. 466470, 5 figs., November, 1913.

Describes more particularly the occurrence of silicified $\operatorname{logs}$ near Flora, Miss.

Brown, C. W. 'See Huntington, no. 541.

- Brown, E. Percy.

124. Some characteristics of the gold bearing veins of Nova Scotia : Canadian Min. Jour., vol. 34, pp. 345-347, 1 fig., June 1, 1913.

Brown, Geo. M.

125. The McAlester coal field in Oklahoma: Coal Age, vol. 4, no. 5, pp. 153155, 9 figs., August 2, 1913.

Brown, Lucius P.

126. The phosphate deposits of continental North America: Intern. Cong. Applied Chemistry, Eighth, 1912, vol. 26. pp. si-11i. [1913?]. 
Brown, Thomas C.

127. Notes on the Silurian limestone of Milesburg Gap, near Bellefonte, Pennsylvania: Am. Jour. Sci., 4th ser., vol. 35, pp. 83-89, 3 figs, January, 1913.

128. Notes on the origin of certain Paleozoic sediments, illustrated by the Cambrian and Ordovician rocks of Center County, Pennsylvania: Jour. Geology, vol, 21, no. 3, pp. 232-250, 7 figs., 1913 ; (abstract), Geol. Soc. America, Bull., vol. 24, no. 1, p. 112, March 24, 1913.

Discusses the origin of conglomerates, oolites, and sandstones of Ordovician and Cambrian age.

Brun, Albert.

129. Note on the lava taken from the Halemaumau pit by Mr. Frank A. Perret in July, 1911, with gas analyses and remarks: Am. Jour. Sci., 4th ser., vol. 36, pp. 484-48T, November, 1913.

Brunton, Stopford.

130. Some notes on titaniferous magnetite: Econ. Geology, vol. $S$, no. 7 , pp. 670-680, 3 pls., October, 1913.

Bryce, George.

131. Everyman's geology of the three prairie provinces of the Canadian West. 68 pp., 2 figs., 2 maps. Winnipeg, 1907.

Gives a general account of the geology of Manitoba, Saskatchewan, and Alberta.

Buehler, H. A.

132. Biennial report of the state geologist [1911 and 1912] : Missouri Bur. Geol. and Mines, 54 pp. 3 pls. (maps), 1913.

133. Memoir of Ernest Robertson Buckley : Geol. Soc. America, Bull., rol. 24, no. 1., pp. 44-48, 1 pl. (port.), March 24, 1913.

Includes a list of his writings.

Burchard, Ernest F.

134. Marble resources of Ketchikan and Wrangell districts [Alaska]: U. S. Geol. Survey, Bull. 542, pp. 52-77, map, 1913.

135. The red iron ores of east Tennessee: Tennessee State Geol. Survey, Bull. 16, 173 pp., 17 pls. (including maps), 30 figs., 1913.

136. Iron ore, pig iron, and steel : U. S. Geol. Survey, Mineral Resources, 1912, pt. 1, pp. 147-202, 2 figs., 1913.

137. Cement; stone; fluorspar and cryolite: U. S. Geol. Survey, Mineral Resources, 1912, pt. 2, pp. 503-524, 702-81.8, 847-853, 3 figs., 6 maps, 1913.

Burckhardt, Carlos.

138. Les mollusques de type boréal dans le Mésozoique mexicain et andin:

Soc. Cient. "Antonio Alzate," Mem. y Rev., t. 32, nos. 1-3, pp. 79-S4, February, 1912.

Denies the distribution of Jurassic Mollusca by climatic zones, in view of the occurrence of boreal types in Mexico.

Burling, Lancaster $\mathrm{D}$.

139. The habitat of the Cambrian Brachiopoda (abstract): Washington Acad. Sci., Jour., vol. 3, no. 7, p. 199, April 4, 1913.

Burroughs, Wilbur Greeley.

140. Economic geology of the Berea sandstone formation of northern Ohio: Econ. Geology, vol. 8, no. 5, pp. 469-481, 1 fig., 1913. 
Burroughs, Wilbur Greeley-Continued.

141. 'The Pittsfield oil field: Min. Mag., vol. 9, no. 5, pp. 354-361, 6 figs., November; 1913.

Includes an account of the geology of the field located in Iorain County, Ohio.

142. The coal fields of Ohio: Colliery Engineer, vol. 33, no. 10, pp. 544-547, 2 figs., May, 1913.

143. The origin of coal : Colliery Engineer, vol. 34, no. 5, pp. 271-274, 5 figs., December, 1913.

Burrows, A. G.

144. The Porcupine area [Ontario] : Intern. Geol. Cong., Twelfth, Guide Book no. 7 (issued by the Ontario Bur. Mines), pp. 109-138, 9 pls., 4 figs., 1913.

145. Annotated guide, Nipigon to Iroquois Falls: Intern. Geol. Cong., Twelfth, Guide Book no. 9 (issued by the Canada Geol. Survey), pp. 159-162, 4 maps, 1913.

146. 'The outlying cobalt-silver areas [Ontario]; South Lorrain silver area; the Gowganda silver area; township of Langmuir, Porcupine area ; Otter township: Ontario, Bureau of Mines, Rept., vol. 19, pt. 2, pp. 134-144, 165-186, 195-196, 27 figs. (including maps), 1913.

Butler, B. S.

147. Geology and ore deposits of the San Francisco and adjacent districts, Utah: U. S. Geol. Survey, Prof. Paper -80, 212 pp., 41 pls., 16 figs., 1913.

148. [Notes on the] San Francisco region, Utah: U. S. Geol. Survey, Bull. 529, pp. 197-199, 1913.

Gives notes on the character and occurrence of the ores.

149. Occurrence of complex and little known sulphates and sulpharsenates as ore minerals in Utah: Econ. Geology, vol. 8, no. 4, pp. 311-322, 1 fig., 1913.

150. Copper: U. S. Geol. Survey, Mineral Resources, 1912, pt. 1, pp. 275-334, 1913.

Butler, B. S., and Dunlop, J. P.

151. Precious and semiprecious metals in the Central States in $1912:$ U. S. Geol. Survey, Mineral Resources, 1912, pt. 1, pp. 437-521, 1913.

Butler, G. Montague.

152. Some recent developments at Leadville; Second paper, The oxidized zinc ores: Econ. Geology, vol. 8, ho. 1, pp. 1-18, 1 pl., 4 figs., January, 1913; Colorado Sçhool of Mines, Quart., vol. 8, no. 1, pp. 9-21, 4 figs., April, 1913.

Butters, R. M.

153. Permian or "Permo-Carboniferous" of the eastern foothills of the Rocky Mountains in Colorado: Colorado Geol. Survey, Bull. 5, pt. 2, pp. 61-94, 1 fig., 1913.

Buttram, Frank.

154. The glass sands of Oklahoma: Oklahoma Geol. Survey, Bull. no. 10, 91 pp., 8 pls., 3 figs., Jinuary, 1913.

Butts, Charles.

155. Contributions to the black shale problem (abstract) : Geol. Soc. America, Bull., vol. 24, no. 1, p. 113, March 24, 1913.

Description of the Barnesboro and Patton quadrangles, Pennsylvania. See Campbell, Clapp, and Butts, no. 169.

[Geologic sections in southeastern Tennessee]. See Ulrich and Butts, no. 1192. 
Buwalda, John P.

156. Faunal zones of the San Pablo formation eist of Walnut Creek, nealr Mount Diablo, California (abstract); Geol. Soc. America, Bull., vol. 24, no. 1, p. 130, March 24, 1913.

Byler, E. A.

Relation of faulting and mineralization in Goldfield [Nevada]. See Barnes and Byler, no. 42.

Byler, E. A., and Davis, Lee W.

157. Topographic model of Cripple Creek district: Min. and Sci. Press, vol. 107, p. 144, 1 fig., July 26, 1913.

Cairnes, D. D.

158. Portions of Atlin district, British Columbia; with special reference to lode mining: Canada Geol. Survey., Mem. no. 37, 129 pl., 32 pls., 9 figs., 1 map (in pocket), 1913.

159. Yukon and Malaspina, general introduction (pp. 39-40) ; the SkagwayWhitehor'se-Dawson section (pp. 51-121) : Intern. Geol. Cong., Twelfth, Guide Book no. 10 (issued by the Canada Geol. Survey), maps, pls., 191.3.

160. Yukon coal fields: The Coal Resources of the World, XII Intern. Geol. Cong., Canada, 1913, vol. 2, pp. 516-520, 1 fig. (map), 1.913.

161. Geological section along the Yukon-Alaska boundary between Yukon and Porcupine rivers (abstract): Geol. Soc. America, Bull., vol. 24, no. \&, pp. 678-679, December 23, 1913.

162. The Chisana placer-gold strike in Alaska: Min. and Eng. World, vol. 39, pp. 935-936, November 22, 1913.

Calkins, Frank Cathcart.

163. Field and office methods in the preparation of geological reports; the Penfield protractor: Econ. Geology, vol. 8, no. 4, pp. 373-376, text fig. 31, 1913.

Geology and ore deposits of the Philipsburg quadrangle, Montana.' See Emmons and Calkins, no. 360 .

Calkins, F. C., and Jones, E. L., jr.

164. Geology of the St. Joe-Clearwater region, Idaho: U. S. Geol. Survey, Bull. 530, pp. 75-86, 1 pl. (map), 1913.

Calvert, Philip P.

165. The fossil odonate Phenacolestes, with a discussion of the venation of the legion Podagrion Selys: Acad. Nat. Sci. Philadelphia, Proc., vol. 65, pt. 2, pp. 225-272, 1 pl., 191.3.

Describes the wing structure of Odonata (dragon fles) from the Miocene shales of Florissant, Colo.

Cameron, R. Clyde.

166. Graphical determination of dip and strike: Min. and Sci. Press, vol. 106, pp. 814-815, 2 figs., May 31, 1913.

Campbell, Marius $\mathrm{R}$.

167. Contributions to economic geology (short papers and preliminary reports), 1911; Part II, Mineral fuels: TJ. S. Geol. Survey, Bull. 531, 361 pp., 24 pls., 10 figs., 1913.

168. The coal reserves of the United States: The Coal Resources of the World, XII Intern. Geol. Cong., Canada, 1913, vol. 1., pp. lxiii-lxiv, vol. 2, pp. 525-339, 1 map in atlas, 1913.

Geologic structure of the Punxsutawney, Curwensville, Houtzdale, Barnesboro, and Patton quadrangles, central Penusylvania. See Ashley and Campbell, no. 19. 
Campbell, Marius R., Clapp, Frederick G., and Butts, Charles.

169. Description of the Barnesboro and Patton quadrangles, Pennsylvania: U. S. Geol. Survey, Geol. Atlas U. S., Barnesboro-Patton folio (no. 189), 13 pp., 6 pls. (maps), 11 figs., 1913.

Camsell, Charles.

170. Geology and mineral deposits of the Tulameen district, British Columbia: Canada Geol. Survey, Mem. no. 26, viii, 188 pp., 23 pls., 2 figs., 4 maps, 1913.

171. Coast Range, Lytton to Vancouver (pp. 256-274) ; fire clay deposits at Clayburn, B. C. (pp. 343-349) : Intern. Geol. Cong., Twelfth, Guide Book no. 8 (issued by the Canada Geol. Survey), maps, pls., figs., 1913.

172. The Similkameen district: Intern. Geol. Cong., Twelfth, Guide Book no. 9 (issued by the Canada. Geol. Survey), pp. 102-131, maps, pls., 1913.

Sudbury, Ontario, to Dunmore, Alberta. See Collins and Camsell, no. 248.

Canada, Department of Mines, Mines Branch.

173. Economic minerals and mining industries of Canada. 77 pp., 19 pls., $1 \mathrm{map}$ (in pocket), Ottawa, 1913.

174. Summary report of the Mines Branch of the Department of Mines for the calendar year ending December 31, 1912. 174 pp., 16 pls., 1 fig., 3 maps. Ottawa, 1913.

\section{Canada Geological Survey.}

175. Guide book, nos. 1-10. [Issued for the Twelfth International Geological Congress.] Ottawa, 1913.

The papers, descriptive of the regions to be visited in the excursions, have been listed under the individual authors.

176. Geological map of the Dominion of Canada and Newfoundland. Scale, 1: 6,336,000. Geology compiled by G. A. Young. 1913.

Capps, Stephen $\mathbf{R}$.

177. The Yentna district, Alaska: U. S. Geol. Survey, Bull. 534, 75 pp., 9 pls. (incl. maps), 7 figs., 1913; (abstract), Washington Acad. Sci., Jour., vol. 3, no. 18, p. 466, November 4, 1913.

Describes the geography, the general geology, the occurrence, character, relations, and distribution of bedded rocks of Paleozolc or Mesozoic and Tertiary age, and of Quaternary deposits, and the gold placers.

Capps, S. R., and Johnson, B. L.

178. Mineral deposits of the Ellamar district [Alaska]: U. S Geol. Survey, Bull. 542, pp. 86-124, map, 1913.

Describes physiographic features, the stratigraphy and geologic structure, and the distribution and geologic relations of the ore deposits, chiefly copper.

Carman, J. Ernest.

179. The Wisconsin drift-plain in the region about Sioux Falls, South Dakota (abstract) : Science, new ser., vol. 37, p. 456, March 21, 1913.

Carney, Frank.

180. Some proglacial lake shorelines of the Bellevue quadrangle, Ohio: Denison Univ., Sci. Lab., Bull., vol. 17, pp. 231-246, 4 figs., March, 1913. 
Carpenter, Everett.

181. Ground water in Boxelder and Tooele counties, Utah: U. S. Geol. Survey, Water-Supply Paper 333, 90 pp., 2 pls. (maps), 9 figs., 1913.

Carter, T. Lane.

182. Gold placers of Arizona: Min. and Sci. Press, vol. 105, pp. 166-168, 3 figs., August 10, 1912.

Case, E. C.

183. Notes on the geology of the Gallina, New Mexico, quadrangle: Michigan Acad. Sci., 14th Rept., pp. 114-115, 1912.

184. Red beds between Wichita Falls, Texas, and Las Vegas, New Mexico, in relation to their vertebrate fauna (abstract): Geol. Soc. America, Bull., vol. 24, no. 4, p. 679, December 23, 1913.

Case, E. C., Williston, S. W., and Mehl, M. C.

185. Permo-Carboniferous vertebrates from New Mexico: Carnegie Inst. Washington, Pub. no. 181, 81 pp., 1 pl., 51 figs., 1913.

Catherall, A. P.

186. The coal fields of Trinidad: The Coal Resources of the World, XII Intern. Geol. Cong., Canadi, 1913, vol, 1, p. lxix, vol. 2, pp. 569573, sketch map in text, 1913.

Cayeux, L.

187. Existence de restes organiques dans les roches ferrugineuses associées aux minerais de fer huroniens des tetats-Unis: Acad. Sci., Paris, Compt. rend., t. 153, pp. 910-912, November 6, 1911.

Describes the occurrence of organic remains in Furontan fronbearing rocks of the rake Superfor region.

Chadwick, George H.

138. Angular unconformity at Catskill (abstract) : Geol. Soc. America, Bull., vol: 24, no. 4, p. 676, December 23, 1913.

Chamberlin, Thomas C.

189. Map of North America during the great ice age. Scale, 104 miles= 1. inch. Chicago, Rand, McNally \& Co., 1913.

190. Contributions from allied sciences to geologic fundamentals (editorial) : Jour. Geology, vol. 21, pp. 279-283, 1913.

191. Diastrophism and the formative processes; I, Introduction : Jour. Geology, vol. 21, no. 6, pp. 517-522, September-October, 1913.

192. Diastrophism and the formative processes; II, Shelf-seas and certain limitations of diastrophisn : Jour. Geology, vol. 21, no. 6, pp. 523533, September-October, 1913.

193. Diastrophism and the formative processes; III, The lateral stresses within the continental protuberances and their relations tó continental creep and sea-transgression: Jour. Geology, vol. 21, no. 7, pp. 577-587, October-November, 1913.

194. Diastrophism and the formative processes; IV, Rejuvenation of the continents: Jour. Geology, vol. 21, no. 8, pp. 673-682, NovemberDecember, 1.913.

195. Report on the study of fundamental problems of geology (abstract) : Carnegie Inst. Washington, Yearbook no. 12, pp. 292-293, 1913.

Chañin, Theodore.

196. The McKinley Lake, district [Alaska]: U. S. Geol. Survey, Bull. 542, pp. 78-80, map, 1913.

Includes notes on the geology and the occurrence and character of gold ores. 
Church, J. A. See Emmons, no. 355, and Jenney, no. 555.

Clapp, Charles $\mathrm{H}$.

197. Field and office methods in the preparation of geological reports (discussion); a modification of the ordinary field method: Econ. Geology, vol. 8, no. 2, pp. 177-1.81, 2 figs., March 1913.

198. Contraposed shorelines: Jour. Geology, vol. 21, no. 6, pp. 537-540, 3 figs., September-October, 1913; (abstract), Geol. Soc. America, Bull., vol. 24 , no. 4, p. 700 , December $23,1913$.

199. Vaucouver Island: Intern. Geol. Cong., Twelfth, Guide Book no. 8 (issued by the Canada Geol. Survey), pp.' 280-342, maps, pls., figs., 1913.

200. Coal fields of Vancouver Island: The Coal Resources of the World, XII Intern. Geol. Cong., Canada, 1913, vol. 2, pp. 509-513, 1 map in atlas, 1913.

201. The coal fields of Queen Charlotte Islands: The Coal Resources of the World, XII Intern. Geol. Cong., Canada, 1913, vol. 2, pp. 513-515, 1913.

Clapp, Frederick G.

202. Outline of the geology of natural gas in the United States: Econ. Geology, vol. S, no. 6, pp. 517-542, 7 figs., 1 pl., September, 1913.

Description of the Barnesboro and Patton quadrangles, Pennsylvania. See Campbell, Clapp, and Butts, no. 169.

Clapp, Frederick G., and Huntley, L. G.

203. Petroleum and natural gas resources of Canada: Canada, Dept. Mines, Mines Branch, Summ. Rept. 1912, pp. 4\&-57, 3 pls., 1913.

Clark, Austin Hobart.

204. Restoration of the genus Eldonia, a genus of free-swimming holothurians from the Middle Cambrian: Zoologischer Anzeiger, Bd. 39, pp. 723-725, August 2, 1912; (abstract) Washington Acad. Sci., Jour., vol. 3, no. 6, p. 167, March 19, 1913.

205. Cambrian holothurians: Am. Naturalist, vol. 47, pp. 488-507, August, 1913.

206. The systematic position of the crinoid family Plicatocrinidæ: Washington Acad. Sci., Jour., vol. 3, no. 20, pp. 494-499, December 4, 1913.

Clark, Bruce I.

207. San Pablo formation on the north side of Mount Diablo, California (abstract) : Geol. Soc. America, Bull., vol. 24, no. 1, p. 130, March 24, 1913.

See also Martin, no. 749 .

Clark, William Bullock, and others.

208. Devonian; Lower, Middle and Upper, and plates: Maryland Geol. Survey, 3 vols., Lower (text), 560 pp., 16 pls., 17 figs.; Middle and Upper (text), 720 pp., 6 pls., 2 figs.; plates (atlas), 156 pp., pls. 17-98, 6-73. Baltimore, The Johns Hopkins Press, 1913.

Clarke, John. Mason.

209. Ninth report of the director of the science division, including the 66th report of the State museum, the $32 d$ report of the State geologist, and the report of the State paleontologist for 1912: New York State Mus., Bull. 164, pp. 5-33, 1913. 
Clarke, John Mason-Continued.

210. The origin of the Gulf of St. Lawrence: New Yolk State Mus., Bull. 164, pp. 132-137, 1 fig., 1913; Soc. Géog. Québec, Bull., vol. 7, no. 1, pp. 29-36, 1 fig. (map), 1913.

211. A notable trilobite from the Perce rock: New York State Mus., Bull. 164, pp. 138-139, 1 pl., 1913.

212. Dana, the zoologist: Geol. Soc. America, Bull., vol. 24, no. 1., pp. 68-69, March 24, 1913.

213. Excursion in eastern Quebec and the maritime provinces; Dalhousie and the Gaspe Peninsula (pp. 85-108, 110-118): Intern. Geol. Cong., Twelfth, Guide Book no. 1 (issued by the Canada Geol. Survey), 1913.

Clarke, John M., and Swartz, Charles K.

214. Systematic paleontology of the Upper Devonian deposits of Maryland: Maryland Geol. Survey, Middle and Upper Devonian, pp. 539-699, 28 pls. (in plates volume), 1913.

Clifford, James 0.

215. Formation and growth of disseminated copper deposits: Mines and Methods, vol. 4, nos. 8 and 10, pp. 189-191, 221-223, April and June, 1913.

Cline, Justus H.

Petrology of a series of igneous dikes in central western Virginial. See Watson and Cline, no. 1243.

Normal faulting in the Cambrian of northern Piedmont, Virginia. See Watson and Cline, no. 1244.

Drainage changes in the Shenandoah Valley region of Virginia. See Watson and Cline, no. 1245.

Cockerell, T. D. A.

216. The genera Parotermes and Hodotermes (Isoptera): Entomological News, vol. 24, no. 1, pp. 6-8, January, 1913.

Describes Parotermes scudderi n. sp. from the Mlocene shales of Florissant, Colo.

217. The first fossil anthomyid fly from Florissant (Dipt.) : Entomological News, vol. 24, no. 7, pp. 295-296, July, 1913.

218. Fossil flowers and fruits, III : 'Torreya, vol. 13 , no. 4, pp. 75-77, 2 figs., April, 1913.

Describes Sambucus ellisia n. sp. and Phalaris? geometrorum n. sp. from the Miocene shales of Florissant, Colo.

219. Ordovician (?) fish remains in Colorado: Am. Naturalist, vol. 47, pp. 246-247, April, 1913.

220. Some fossil insects from Florissant, Colorado: U. S. Nat. Mus., Proc., vol. 44, pp. 341-346, 1 pl., 3 figs., April 30, 1913.

221. Two fossil insects from Florissant, Colorado, with a discussion of the venation of the Aeshnine dragon flies: U. S...Nat,.:Mus., Proc., vol. 45, pp. 577-583, 3 figs., 1913.

$\therefore$ :

222. The genus Phryganea (Trichoptera) in the Florissant shales: Psyche, vol. 20, no. 2, pp. 95-96, April, 1913.

223. Remarks on fossil insects (abstract, with discussion): Entomological Soc. Washington, Proc., vol. 15, no. 3, pp. 123-128, 1913.

224. The first fossil mydaid fly: Entomologist, vol. 46, pp. 207-208, July, 1913. 
Cockerell, T. D. A.-Continued.

225. A fossil asilid fly from Colorado: Entomologist, vol. 46, pp. 213-214, July, 1913.

226. Some fossil insects from Florissant, Colorado: Canadian Entomologist, vol. 45, no. 7, pp. 229-233, 1 fig., July, 1913.

227. Observations on fish scales: U. S. Bur. Fisheries, Bull., vol. 32, Doc. no. 779 , pp. 117-174, 9 pls., 52 figs., October 25, 1913.

Includes notes on fossil forms.

228. 'The fauna of the Florissant (Colorado) shales: Am. Jour. Sci., 4th ser., vol. 36, pp. 498-500, November, 1913.

Gives a list of fossils identified from the Miocene shales of Florissant, Colorado.

Colburn, E. A., jr.

229. Replacement deposits in the Ajax mine [Victor, Colo.] : Eng. and Min. Jour., vol. 95, no. 15, pp. 739-741, 3 figs., April 12, 1913.

230. Influence of flat dike on ore formation: Eng. and Min. Jour., vol. 96, pp. 599-600, 1 fig., September 27, 1913.

Describes the occurrence and probable mode of formation of ore bodies at Cripple Creek, Colorado.

Coleman, A. P.

231. The nickel industry, with special reference to the Sudbury region, Ontario: Canada, Dept. Mines, Mines Branch, 206 pp., 63 pls., 14 figs., 9 maps, 1913.

232. The Whiskey Lake area : Ontario, Bureau of Mines, Twenty-second Ann. Rept., vol. 22, pt. 1, pp. 146-154, 5 figs. (including map), Toronto, 1913.

Describes the geologic and physiographic features of the area, and deposits of copper and gold.

233. The Massey copper mine area: Ontario, Bureau of Mines, Twentysecond Ann. Rept., vol. 22, pt. 1, pp. 155-160, 1 map, Toronto, 1913.

Describes the general geology and the occurrence and character of copper deposits.

234. Glacial phenomena of Toronto and vicinity: Ontario, Bureau of Mines, Twenty-second Ann. Rept., vol. 22, pt. 1, pp. 238-2555, 7 figs. '(including section), Toronto, 1913.

235. Iroquois beach: Intern. Geol. Cong., Twelfth, Guide Book no. 4 (issued by the Canada Geol. Survey), pp. 71-74, maps, 1913.

236. Toronto and vicinity: Intern. Geol. Cong., Twelfth, Guide Book no. 6, (issued by the Ontario Bur. Mines), pp. 7-34, 1 map, 5 pls., 1 fig., 1913.

237. The Sudbury area [Ontario]: Intern. Geol. Cong., Twelfth, Guide Book no. 7 (issued by the Ontario Bur. Mines), pp. 11-48, maps, $12 \mathrm{pls.}$ 6 figs., 1913.

238. Sudbury to Cartier, annotated guide: Intern. Geol. Cong., Twelfth, Guide Book no. 8 (issued by the Canada Geol. Survey), pp. 13-14, 1913.

239. Metamorphism in the pre-Cambrian of northern Ontario: Intern. Geol. Cong., XI, Stockholm, 1910, Compt. rend., pp. 607-616, 1912.

240. Methods of classification of the Archean of Ontario: Intern. Geol. Cong., XI, Stockholm, 1910, Compt. rend., pp. 721-728, 1912.

241. The Lower Huronian ice age (with discussion): Intern. Geol. Cong., XI, Stockholm, 1910, Compt. rend., pp. 1069-1072, 1 pl., 1912.

See also Leverett, no. 687 . 
Collier, A. J.

242. Coal resources of Cowlitz River valley, Cowlitz and Lewis counties, Washington: U. S. Geol. Survey, Bull. 531, pp. 323-330, 1 pl. (map), 1913.

Collins, George E.

243. The application of genetic theories to the search for local enrichments in veins: Colorado Sci. Soc., Proc., vol. 10, pp. 211-232, April, 1913.

Collins, W. H.

244. The geology of Gowganda mining division [Ontario]: Canada Geol. Survey, Mem. no. 33, 121 pp., 4 pls., 5 figs., geol. map, 1913.

245. The outlying cobalt-silver areas [Ontario]; Florence Lake, Shining

- Tree and Rose Creek areas: Ontario, Burea of Mines, Rept., vol. 19, pt. 2, p. 194, 1913.

246. Annotated guide, Winnipeg to Nipigon: Intern. Geol. Cong., Twelfth, Guide Book no. 9 (issued by the Canada Geol. Survey), pp. 153-159, 4 maps, 1913.

247. A classification of the pre-Cambrian formations in the region east of Lake Superior: Inter'n. Geol. Cong., 'Twelfth, Canada, 9 pp., 1 map, 1913 (advance copy).

Collins, W. H., and Camsell, Charles.

248. Sudbury, Ontario, to Dunmore, Alberta : Intern. Geol. Cong., Iwelfth, Guide Book no. 9 (issued by the Canada Geol. Survey), pp. 11-15, 1913.

Collins, W. H., and Wilson, M. E.

249. Winnipeg to Cochrane via National Transcontinental Railway: Intern. Geol. Cong., Twelfth, Guide Book no. 9 (issued by the Canada Geol. Survey), pp. 149-153, pl., 1913.

Colvocoresses, G. M.

250. Cobalt conglomerate [Ontario] : Min. Mag., vol. 8, no. 1., pp. 43-44, 2 figs., January, 1913.

Condit, D. Dale.

251. Conemaugh formation in Ohio: Ohio Geol. Survey, Fourth Series, Bull. 17, 363 pp., 16 pls., 17 figs., 10 maps, 1912.

252. Deep wells at Findlay, Ohio: Am. Jour. Sci., 4th ser., vol. 36, pl. 1231.30, August, 1913.

Connor, M. F.

253. Some notes on rock analysis: Intern. Geol. Cong., 'Twelfth, Canada, 6 pp., 1913 (advance copy).

Cook, C. W.

Die Kristallformen des Jodyrits von Tonopah, Nevada. See Kraus and Cook, no. 638.

Cooke, H. C.

254. The secondary enrichment of silver ores :' Jour. Geology, vol. 21, no. 1, pp. 1-28, 1 fig., January-February, '1913:

Coons, A. T.

255. Slate: U. S. Geol. Survey, Mineral Resources, 1912, pt. 2, pp. 675-692, 1913. 
Cornish, Vaughan.

256. Waves of the sea and other water waves. 374 pp., 49 pls., 6 figs. Chicago, Open Court Publishing Co., 1910.

257. On the Panama Canal, and the formation of gravitation waves in the Culebra cut: Geog. Jour., vol. 41, pp. 239-243, 1 fig., March, 1913.

Corral, José Isaac del.

258. Excursión geológica al placer de Batabanó : Soc. Cubana Ingenieros, Rev., vol. 5, no. 1, pp. 32-42, January, 1913.

Gives notes on the phosphate deposits and other geologic features of coral islands south of Batabano, Cuba.

Cossmann, M.

259. Étude comparative de fossiles miocéniques recueillis a la Martinique et

à l'Isthme de Panama: Jour. de Conchyliologie, vol. 61, no. 1, pp.

1-64, 5 pls., September 5, 1913.

Crane, W. R.

Describes Miocene mollusks collected in Martinique.

260. The Bering River coal field, Alaska : Coal Age, vol. 3, no. 6, pp. 212-214, 2 figs., February 8, 1913.

261. The soft coals of the Bering field: Coal Age, vol. 3, no. 8, pp. 298-300, 2 figs., February 22, 1913.

262. Original impurities of Bering coals: Coal Age, vol. 3, no. 12, pp. 444445, 4 figs., March 22, 1913.

263. Folding troubles in the Bering [coal] field: Coal Age, vol. 3, no. 15, pp. 568-570, 8 figs., April 1.2, 1913.

264. A brief account of the Matanuska [coal] field [Alaska]: Coal Age, vol. 3, no. 17, pp. 630-632, 4 figs., April 26, 1913.

265. The Matanuska River coal field by districts [Alaska]: Coal Age, vol. 4, no. 5, pp. 148-152, 12 figs., August 2, 1913.

Crawford, R. D.

266. Geology and ore deposits of the Monarch and Tomichi districts, Colorado: Colorado State Geol. Survey, Bull. 4, 317 pp., 25 pls. (incl. maps and sections), 15 figs., 1913.

267. Field and office methods in the preparation of geological reports; some methods of geologic field work: Econ. Geology, vol. 8, no. 4, pp. 386-389, 1913.

Crenshaw, J. L.

The sulphides of zinc, cadmium, and mercury; their crystalline forms and genetic conditions (abstract). See Allen and Crenshaw, no. 14.

Crider, A. F.

Portland cement materials and industry; local occurrences of Vicksburg limestone. See Eckel, no. 342.

Cross, Whitman.

268. Certain criticisms of the quantitative classification of igneous rocks (with discussion) : Intern. Geol. Cong., XI, Stockholm, 1910, Compt. rend., pp. 971-976, 1912.

269. Lavas of Hawaii and their relations (abstract) : Geol. Soc. America, Bull., vol. 24, no. 4, p. 684, December 23, 1913.

Cunningham-Craig, E. H.

270. Report on the oilfields of Barbados. 14 pp., 8 figs. (maps). Barbados, T. E. King \& Co., Printers to the Government of Barbados, 1913. 
Curran, Thomas is. V.

271. Carnotite: Eng. and Min. Jour., vol. 96, pp. 1165-1167, 1223-1225, December $20^{\circ}$ and $27,1913$.

Curtis, Geo. Carroll.

272. Work going on at Kilauea volcano: Science, new ser., vol. 38, pp. 355358, September 12, 1913.

Cushing, H. F.

273. Northumberland volcanic plug: Geol. Soc. America, Bull., vol. 24, no. 2, pp. 335-350, 2 pls., 4 figs., June 1.6, 1.913 (discussion by L. V. Pirsson, J. Volney Lewis, and I. C. White) : vol. 24, no. 4, pp. 683-684, December 23, 1913.

Describes relations to surrounding strata, structural features, and the character and composition of the component rock and discusses

Dale, T. Nelson. the origin of the igneous mass and its age.

274. The commercial qualities of the slates of the United States and their localities: U. S. Geol. Survey, Mineral Resources, 1912, pt. 2, pp. 693-707, 1 pl. (map), 1913.

275. The commercial marbles of western Vermont (abstract) : Washington Acad. Sci., Jour., vol. 3, no. 5, p. 152, March 4, 1913.

276. The Ordovician outlier at Hyde Manor in Sudbury, Vermont (second paper) : Am. Jour. Sci., 4th ser., vol. 36, pp. 395-39S, 1 fig., October, 1913.

Dall, William Healey.

277. On a brackish-water Pliocene fauna of the southern Coastal Plain: U. S. Nat. Mus., Proc., vol. 46, pp. 225-227, 3 pls., December 6, 1913.

Daly, Reginald Aldworth.

278. Geology of the North American Cordillera at the forty-ninth parallel: Canada, Dept. Interior, Report of the Chief Astronomer for 1910, vols. 2 and 3, pp. 1-799, 73 pls., 42 figs., 55 tables, 1913.

279. Introduction to the geology of the Cordiller:a (pp. 111-167) ; annotated guide, Golden to Savona (pp. 202-234): Intern. Geol. Cong., 'Twelfth, Guide Book no. 8 (issued by the Canada Geol. Survey), maps, pls., figs., 1913.

280. Some chemical conditions in the pre-Cambrian ocean: Intern. Geol. Cong., XI, Stockholm, 1910, Compt. rend., pp. 503-509, 1912.

281. Sills and laccoliths illustrating petrogenesis: Intern. Geol. Cong., 'Twelfth, 16 pp., 1913 (advance copy).

See also Day and Shepherd, no. 300.

Darton, N. H.

282. Sand available for filling mine workings in the northern anthracite basin of Pennsylvania: U. S. Bur. Mines, Bull. 45, 33 pp., 8 pls. (incl. maps), 5 figs., 1913.

Describes the distribution, character, and amount of various sand and gravel deposits in Luzerne and Lackawanna counties, $\mathrm{Pa}$.

283. Buried valley of Susquehanna River in Luzerne County, Pennsylvania : Jour. Geology, vol. 21, no. 6, pp. 557-563, 1. fig., September-October, 1913 ; (abstract) Assoc. Am. Geog., Annals, vol. 2, p. 111. [1913].

284. Construction of a structure map of the northern anthracite field (abstract): Washington Acad. Sci., Jour., vol. 3; no. 7, pp. 199-200, April 4, 1913.

$38416^{\circ}-$ Bull. $584-14-3$ 
Darton, N. H.-Continued.

285. Some structural features in the northern anthracite coal field (abstract) : Geol. Soc. America, Bull., vol. 24, no. 4, pp. 676-677, December 23, 1913.

286. Geothermal data of the United States (abstract): Geol. Soc. America, Bull., vol. 24, no. 4, p. 677, December 23, 1913.

See also Gregory, no. 440.

Davenport, R. W.

Placer mining in the Yukon-Tanana region [Alaska]. See Ellsworth and Davenport, no. 347.

Davis, Charles A.

287. Peat: U. S. Geol. Survey, Mineral Resources, 1912, pt. 2, pp. 497-501, 1913.

288. Peat deposit of geological interest near New Haven, Connecticut (abstract) : Geol. Soc. America, Bull., vol. 24, no. 4, p. 700, December 23, 1913.

Davis, Charles $\mathrm{H}$.

289. New species from the Santa Lucia Mountains, California, with a discussion of the Jurassic age of the slates at Slates Springs: Jour. Geology, vol. 21, no. 5, pp. 453-458, 7 figs., 1913.

Discussion of the Jurassic age of the slates at Slate Springs, Monterey County, California (abstract): Geol. Soc. America, Bull., vol. 24, no. 1, p. 131, March 24, 1913.

Davis, E. F.

290. The registration of earthquakes at the Berkeley station and at the Lick Observatory station from April 1 to September 30, 1912: California, Univ., Bull. Seism. Stations, no. 4, pp. 69-95, May 20, 1913.

291. The Marvin strong-motion seismograph: Seismol. Soc. America, Bull., vol. 3, no. 4, pp. 195-202, 6 figs., December, 1913.

Davis, Lee $\mathrm{W}$.

Topographic model of Cripple Creek district. See Byler and Davis, no. 157.

Davis, William Morris.

292. American studies on glacial erosion: Intern. Geol. Cong., XI, Stockholm, 1910, Compt. rend., pp. 419-427, 1912.

293. Dana's confirmation of Darwin's theory of coral reefs: Am. Jour. Sci., 4th ser., vol. 35, pp. 173-188, 1 fig., February, 1913; Nature, vol. 90, pp. 632-634, 1 fig., 1913; (abstract) Science, new ser., vol. 37, p. 724, May 9, 1913.

294. Physical geography of land areas: Am. Year Book, 1912, pp. 617-620, New York, 1913.

295. Nomenclature of surface forms on faulted structures: Geol. Soc. America, Bull., vol. 24, no. 2, pp. 187-216, 5 figs., June 6, 1913.

296. The Grand Canyon of the Colorado: Jour. Geography, vol. 11, pp. 310 314, 1 fig., June, 1913.

297. Submerged valleys and barrier reefs: Nature, vol. 91, pp. 423-424, 1913.

298. Speculative nature of geology (abstract): Geol. Soc. America, Bull., vol. 24, no. 4, pp. 686-687, December 23, 1913.

Report of the committee on the nomenclature of faults. See Reid and others, no. 967 .

See also Day and Shepherd, no. 300. 
Day, Arthur L.

299. Are quantitative physico-chemical studies of rocks practicable? (with discussion): Intern. Geol. Cong., XI, Stockholm 1910, Comp. rend., pp. 965-967, 1912 ; (abstract) Washington Acad. Sci., Jour., vol. 3 , no. 20 , p. 502 , December $4,1913$.

Geophysical research: Smithsonian Inst., Ann. Rept. for 1912, pp. 359-369, 1913. Reprinted from Washington Acad. Sci., Jour., vol. 1, pp. 247-260, 1911.

See also Huntington, no. 541, and Johnston and Adams, no. 565.

Day, Arthur L., and Shepherd, E. S.

300. Water and volcanic activity: Geol. Soc. America, Bull., vol. 24 , no. 4, pp. 573-606, 11 pls., December 16, 1913; (discussion by W. M. Davis, R. A. Daly, J. F. Kemp, and E. Howe) : p. 707, December 23, 1913.

301. Water and the magmatic gases: Washington Acad. Sci., Jour., vol. 3, no. 18, pp. 457-463, November 4, 1913.

Day, David T.

302. Platinum and allied metals: U. S. Geol. Survey, Mineral Resources, 1912, pt. 1, pp. 1055-1059, 1913.

303. Petroleum; Asphalt: U. S. Geol. Survey, Mineral Resources, 1912, pt. 2, pp. 361-495, 997-1006, 1913.

Deeley, R. M.

304. North American and European drift deposits: Geol. Mag., dec. 5, vol. 10, pp. 14-17, 1 table, 1 fig., January, 1913.

Dégoutin, N.

305. Les grottes à cristaux de gypse de Naica (Mexique): Soc. Cient. "Antonio Alzate," Mem. y Rev., t. 32, nos. 4-6, Rev. pp. 35-38, (see also pp. 32-34), 3 figs., August, 1912.

Describes very large crystals of gypsum and the caves of Naica, Mexico, from which they were obtained.

DeLury, J. S.

306. The outlying cobalt-silver areas [Ontario]; the area west of Bay Lake on the Montreal River: Ontario, Bureau of Mines, Rept., vol. 19, pt. 2, pp. 152-154, 1913.

Demming, Henry C.

307. The geology, petrography, and mineralogy of York County-past, present, and future: Eng. Soc. York, Pennsylvania, Proc., vol. 2, pp. 65-70, 1913.

Denis, Theo. C.

308. Report on mining operations in the Province of Quebec during the year 1912: Quebec (Province), Dept. Colonization, Mines, and Fisheries, Mines Branch, 236 pp., pls., and figs., 1913.

309. Extracts from reports on the District of Ungava recently added to the Province of Quebec under the name of the Territory of New Quebec: Dept. Colonization, Mines and Fisheries, Mines Branch, 160 pp. (French edition, 231 pp.), 10 pls., 1 map, 1913.

Includes an account of the geology and the economic minerals.

Denison, F. Napier.

310. The horizontal pendulum in relation to certain phenomena: Seismol. Soc. America, vol. 3, no. 3, pp. 103-112, 5 figs., September, 1913. 
Depéret, Charles.

311. The Oligocene of the Roanne Basin and its vertebrate fauna; with a postscriptum by C. R. Eastman: Am. Jour. Sci., 4th ser., vol. 35, pp. 350-352, April, 1913.

Discusses the correlation of American Tertiary horizons with those of France.

Deussen, Alexander.

312. The survey of the artesian water resources of southwest Texas: Irrigationist, San Antonio, Texas, vol. 1, no. 1, pp. 9-11, 1 fig., May, 1913.

DeWolf, F. W.

313. Cooperative investigation of the Mississippian formations: Science, new ser., vol. 38, pp. 706-707, November 14, 1913.

Dickerson, Roy E.

314. Fauna of the Eocene at Marysville Buttes, California: California, Univ., Dept. Geology, Bull., vol. 7, no. 12, pp. 257-298, 4 pls., 2 figs., April 29, 1913.

315. Minutes of the Pacific Coast section of the Paleontological Society [third annual meeting, April 6, 1912] : Geol. Soc. America, Bull., vol. 24, no. 1, pp. 126-132, March 24, 1913.

316. Eocene of San Pedro Point, San Mateo County, California (abstract, with discussion by A. C. Lawson and J. C. Merriam) : Geol. Soc. America, Bull., vol. 24, no. 1, pp. 126-127, March 24, 1913.

317. Stratigraphic and faunal relations of the Martinez and Tejon south of Mount Diablo, California (abstract, with discussion by G. D. Louderback and F. M. Anderson) : Geol. Soc. America, Bull., vol. 24, no. 1, p. 127, March 24, 1913.

Dickson, Charles W.'

318. The ore deposits of Sudbury, Ontario [reprinted from Am. Inst. Min. Eng., Trans., vol. 34, pp. 3-65, 1904]. In Emmons, S. F., Ore deposits, pp. 455-516, 26 figs., published by the American Institute of Mining Engineers, New York, 1913.

Diller, J. S.

319. Memoir of Clarence Edward Dutton : Geol. Soc. America, Bull., vol, 24, no. 1, pp. 10-18, 1 pl. (port.), March 24, 1913. Includes a list of his writings.

320. Chromic iron ore: U. S. Geol. Survey, Mineral Resources, 1912, pt. 1, pp. 1047-1054, 1913.

321. Asbestos; talc and soapstone: U. S. Geol. Survey, Mineral Resources, 1912, pt. 2, pp. 985-995, 1133-1160, 1913.

Dolbear, C. E.

322. The Searles Lake potash deposit [California]: Eng. and Min. Jour., vol. 95, no. 5, pp. 259-261, 3 figs., February 1, 1913.

Dole, R. B.

323. Exploration of salines in Silver Peak Marsh, Nevada: U. S. Geol. Survey, Bull. 530, pp. 330-345, 3 figs. (including map), 1913.

Don, John $\mathbf{R}$.

324. The genesis of certain auriferous lodes (with discussion by J. LeConte, S. F. Emmons, G. F. Becker, A. Winslow, and W. P. Blake) [reprinted in part only from Am. Inst. Min. Eng., Trans., vol. 27, pp. 564-668, 993-1003, 1898, and vol. 28, pp. 799-803, 1899]. In Emmons, S. F., Ore deposits, pp. 162-215, 2 figs., published by the American Institute of Mining Engineers, New York, 1913. 
Dopp, Mary.

325. Geological and geographical conditions affecting the development of Wisconsin: Am. Geog. Soc., Bull., vol. 45, pp. 401-412, 5 figs., June, 1913.

Dowling, D: B.

326. Winnipeg to Bankhead: Intern. Geol. Cong., Twelfth, Guide Book no. 8 (issued by the Canada Geol. Survey), pp. 77-101, maps, pls., 1.913.

327. Dunmore to Burmis (pp. 15-18) ; Calgary, Alberta, to Winnipeg, Manitoba, via Grand Trunk Pacific Railway (pp. 131-149) : Intern. Geol. Cong., Twelfth, Guide Book no. 9 (issued by the Canada Geol. Survey), maps, pls., figs., 1913.

328. Introduction: The Coal Resources of the World, XII Intern. Geol. Cong., Canada, 1913, vol. 1, pp. xvii-xxxix, 1913.

329. The coal fields and coal resources of Canada: The Coal Resources of the World, XII Intern. Geol. Cong., Canada, 1913, vol. 1, pp. lxiilxiii, vol. 2, pp. 439-523, 8 figs. in text, 8 maps in atlas, 1913.

The cosl resources of the world ... XII International Geological Congress, Canada, 1913. See McInnes, Dowling, and Leach, no. 733.

Dryer, Charles $R$.

330. Wabash studies: Indiana Acad. Sci., Proc., 1912, pp. 199-213, 12 figs., 3 sketch maps, 1913.

Describes terraces and other physiographic features in the Wabash Valley, Indiana.

Drysdale, Charles W:

331. Western part of the belt of interior plateaus, Savona to Lytton [British Columbia] : Intern. Geol. Cong., 'Twelfth, Guide Book no. 8 (issued by the Canada Geol. Survey), pp. 234-256, 1 map, 4 pls., 1913.

\section{Dulieux, E.}

332. Preliminary report on some iron-ore deposits in the Province of Quebec: Quebec (Province), Dept. Colonization, Mines, and Fisheries, Mines Branch, Rept. on Mining Operations, 1912, pp. 65-130, 4 pls., 10 figs., 1913.

333. Le district aurifère de Porcupine, Province d'Ontario (Canada): Soc. de l'Industr. Min., Saint Ettienne, Bull., $5^{\circ}$ sér., t. 4, 1. S, p1. 122154, 5 figs., August, 1913.

Describes the geology and the ore deposits of the Porcupine goldbearing district of Ontario, Canada.

Dumble, E. T.

The occurrence of gold in the Eocene deposits of Texas: Am. Inst. Min. Eng., Trans., vol. 44, pp. 588-591, 1913. See no. 295 of the bibliography for 1912, U. S. Geol. Survey, Bull. 545.

Dunlop, J. P.

334. Metals and metallic ores in 1911 and 1912 : U. S. Geol. Survey, Mineral Resources, 1912, pt. 1, pp. 139-145, 1913.

Precious and semiprecious metals in the Central States in 1.912. See

Butler and Dunlop, no. 151. 
Eakin, Henry M.

335. A geologic reconnaissance of a part of the Rampart quadrangle, Alaska :

U. S. Geol. Survey, Bull. 535, 38 pp., 8 pls., 1913; (abstract), Washington Acad. Sci., Jour., vol. 3, no. 18, pp. 467-468, November 4, 1913.

336. Gold placers of the Ruby district [Alaska] : U. S. Geol. Survey, Bull. 542, pp. 279-292, map, 1913.

Includes an account of the geology and mineralization.

337. Gold placers of the Innoko-Iditarod region [Alaska]: U. S. Geol. Survey, Bull. 542, pp. 293-303, 1913.

Includes notes on the geology and mineralization.

338. Quaternary problems of central Alaska (abstract) : Washington Acad. Sci., Jour., vol. 3, no. 10, pp. 301-302, May 19, 1913.

Earle, R. B.

339. The genesis of certain Paleozoic interbedded iron ores (abstract, with discussion by J. F. Kemp, G. F. Kunz, J. J. Stevenson, J. E. Woodman, A. W. Grabau, A. B. Picini) : Science, new ser., vol. 38, pp. 281-282, August 22, 1913.

Eastman, Charles R.

340. Textbook of paleontology, adapted from the German of Karl A. von Zittel. Second edition, vol. 1, 839 pp., 1594 figs. London, Macmillan and Co., 1913.

341. Brain structures of fossil fishes from the Caney shales (abstract) : Geol. Soc. America, Bull., vol. 24, no. 1, pp. 119-120, March 24, 1913.

Eckel, Edwin C.

342. Portland cement materials and industry in the United States; with contributions by Ernest F. Burchard, A. F. Crider, G. B. Richardson, Eugene A. Smith, J. A. Taff, E. O. Ulrich, and W. H. Weed: U. S. Geol. Survey, Bull. 522, 401 pp., 19 pls. (maps), 2 figs., 1913.

343. Brown iron ores as cavity fillings: Eng. and Min. Jour., vol. 96, pp. 1-2, 1 fig., July 5, 1913.

Describes a small ore deposit in progress of formation near Low. moor, Virginia.

344. Engineering applications of geology : Eng. Record, vol. 67, pp. 667-668, 711-712, June 14 and 28, 1913.

Eddingfield, F. T.

345. Manganese in superficial alteration: Econ. Geology, vol. 8, no. 5, pp. 499-501, 1913.

Eddy, Lewis $\mathrm{H}$.

346. The Mother Lode region, California : Eng. and Min. Jour., vol. 95, no. 8, pp. 405-410, 6 figs. (incl. map and sections), February 22, 1913.

Ellsworth, C. E., and Davenport, R. W.

347. Placer mining in the Yukon-Tanana region [Alaska]: U. S. Geol. Survey, Bull. 542, pp. 203-222, 1913.

Ellsworth, H. V.

348. The crystal habit of topaz from New Brunswick, Canada: Mineral. Mag., vol. 17, pp. 39-44, 2 figs., 1913.

Elsing, Morris $\mathrm{J}$.

349. Relation of outcrops to ore at Cananea [Mexico] : Eng. and Min. Jour., vol. 95, no. 7, pp. 357-362, 6 figs., February 15, 1913. 
Emerson, B. K.

350. The question of the older and newer Appalachians: Science, new ser., vol. 37, pp. 20-21, January 3, 1913.

Emmens, Newton W.

351. Mining in Lynn Creek district, British Columbia : Min. and Eng. World, vol. 38, pp. 345-347, 7 figs., February 15, 1913.

Emmons, Samuel Franklin.

352. Ore deposits; a sequel to the second edition of "The genesis of ore deposits," by Franz Posepny and others; being a compilation of contributions to this science from the Transactions of the American Institute of Mining Engineers, with a critical introduction and synopsis. 954 pp. New York, published by the Institute, 1913.

353. The genesis of certain ore deposits [reprinted from Am. Inst. Min. Eng., Trans., vol. 15, pp. 125-147, 1887]. In Emmons, S. F., Ore deposits, pp. 1-25, published by the American Institute of Mining Engineers, New York, 1913.

354. Structural relations of ore deposits [reprinted from Am. Inst. Min. Eng., Trans., vol. 16, pp. S04-\$39, 2 figs., 1888]. In Emmons, S. F., Ore deposits, pp. 26-64, 2 figs., published by the American Institute of: Mining Engineers, New York, 1913.

355. Geological distribution of the useful metals in the United States (with discussion by J. A. Church, A. Winslow, S. F. Emmons, and W. H. Merritt) [reprinted in extract from Am. Inst. Min. Eng., Trans., vol. 22 , pp. 53-95, 732-738, 1894, and vol. 24 , pp. $755-756,1895$ ]. In Emmons, S. F., Ore deposits, pp. 65-91, published by the American Institute of Mining Engineers, New York, 1913.

356. Some mines of Rosita and Silver Cliff, Colorado [reprinted in part only from Am. Inst. Min. Eng., Trans., vol. 26, pp. 773-823, 1897]. In Emmons, S. F., Ore deposits, pp. 139-161, 1 fig., published by the American Institute of Mining Engineer's, New York, 1913.

\section{Emmons, William Harvey.}

357. The agency of manganese in the superficial alteration and secondary enrichment of gold deposits in the United States [reprinted from Am. Inst. Min. Eng., Trans., vol, 42, pp. 3-73, 1912]. In Emmons, S. F., Ore deposits, pp. 759-828, 4 figs., published by the American Institute of Mining Engineers, New York, 1913.

358. The enrichment of sulphide ores: U. S. Geol. Survey, Bull. 529, 260 pp., 1913; (abstract by Sidney Paige), Washington Acad. Sci., Jour., vol. 3, no. 17, pp. 454-455, October 19, 1913.

359. The mineral composition of primary ore as a factor determining the vertical range of metals deposited by secondary processes: Intern. Geol. Cong., Twelfth, Canada, 9 pp., 1913 (advance copy).

Emmons, William Harvey, and Calkins, Frank Cathcart.

360. Geology and ore deposits of the Philipsburg quadrangle, Montana: U. S. Geol. Survey, Prof. Paper 78, 271 pp., 17 pls. (incl. maps), 55 tigs., 1913.

Emmons, W. H., and Harrington, G. L.

361. A comparison of waters of mines and of hot springs: Econ. Geology, vol. 8 , no. 7, pp. 653-669, 2 figs., October, 1913. 
Emmons, W. H., and Larsen, E. S.

362. A preliminary report on the geology and ore deposits of Creede, Colorado: U. S. Geol. Survey, Bull. 530, pp. 42-65, 3 figs., 1913.

363. The hot springs and the mineral deposits of Wagon Wheel Gap, Colorado : Econ. Geology, vol. 8, no. 3, pp. 235-246, 3 figs., 1913.

Engelbach, $\mathrm{H}$.

364. Les minerais de fer du lac Supérieur (États-Unis): Soc. Ind. Min., Bull., 5 sér. t. 4, livr. 10, pp. 329-370, 8 figs., October, 1913.

Gives an account of the iron deposits of the Lake Superior region.

Engerrand, J., and Paredes, T.

365. Informe relativo á la parte occidental de la región norte de la Baja

California: Mexico, Inst. Geol., Parerg., t. 4, nos. 2-10, pp. 277306, 22 pls., 1913.

Includes notes on the geology and mineral resources of the western part of the peninsula of Lower California.

Fairchild, Herman I.

366. Pleistocene geology of New York State: Geol. Soc. America, Bull., vol. 24, no. 1, pp. 133-162, March 25, 1913; Science, new ser., vol. 37, pp. 237-249, 290-299, February 14 and $21,1913$.

Faribault, E. R.

367. Excursion in eastern Quebec and the maritime provinces; the goldbearing series of Nova Scotia (pp. 15s-192) ; Oldham gold district pp. 192-196) ; annotated guide, Enfield, Oldham gold district (pp. 196-205) : Intern. Geol. Cong., Twelfth, Guide Book no. 1. (issued by the Canada Geol. Survey), 1913.

Fenneman, N. M.

368. The Yellowstone National Park: Jour. Geography, vol. 11, pp. 314-320, 2 figs., June, 1913.

Fenner, Clarence N.

369. The stability relations of the silica minerals: Am. Jour. Sci,, 4th ser., vol. 36, pp. 331-3s4, 9 figs., October, 1913.

370. Various forms of silica and their mutual relations (abstract): Geol. Soc. America, Bull., vol. 24, no. 4, p. 681, December 23, 1913.

Study of a contact metamorphic ore deposit, the Dolores mine, at Matehuala, S. L. P., Mexico (abstract). See Spurr, Garrey, and Fenner, no. 1099.

Ferguson, H. C.

A selected list of the more important contributions to the investigation of the origin of metalliferous ore deposits. See Irving, Smith, and Ferguson, no. 549.

Finlay, George Irving.

371. Introduction to the study of igneous rocks. vii, 228 pp., 2 pls., 59 figs., 2 tables. New York; McGraw-Hill Book Company, 1913.

Flagg, Arthur L.

372. The Elk City mining district, Idaho County, Idaho: Am. Inst. Min. Eng., Bull. no. 76, pp. 571-580, 1 fig. (map), April, 1913.

Includes notes on the local geology and the character and occur rence of the gold ores.

373. Buffalo Hump mining district, Idaho: Min. and Eng. World, vol. 38, pp. 813-814, 1 fig., April 26, 1913

374. Preparation of rock sections: Eng. and Min. Jour., vol. 95, no. 23, pp. 1135-1136, Jane 7, 1913. 
Flores, Teodoro.

375. Algunos datos relativos a la mina de "La Delfina," Distrito de Bravos, Estado de Guèrrero: Soc. Geol. Mexicana, Bol., t. S, pt. 1, pp. v-vii, 9-20, 2 pls., 1912.

Describes the local geology and the occurrence, character, geologic relations, and origin of silver-bearing deposits.

Flores, T., and González, P., jr.

376. Exploración de la parte central elevada de la porción norte de la Península de la Baja California: Mexico, Inst. Geol., Parerg., t. 4, nos. 2-1.0, pp. 237-275, 21. pls., 1913.

Includes notes on the geology and mineral resources of the northern part of the peninsula of Lower Californin.

Foerste, August F.

377. The geology of the Clay Cliffs, Cape Smyth, Manitoulin Island: Intern. Geol. Cong., Twelfth, Guide Book no. 5 (issued by the Canada Geol. Survey), pp. 76-84, 2 figs., 1913.

378. The Mohawkian (middle Ordovician) strata northenst of Manitoulin Island: Intern. Geol. Cong., Twelfth, Guide Book no. 5 (issued by the Canada Geol. Survey), pp. 84-89, 1. map, 1913.

379. Richmond formations of the provinces of Ontario and Quebec in Canada (abstract) : Geol. Soc. America, Bull., vol. 24, no. 1, p. 110, March 24, 1913.

Foote, H. W., and Bradley, H. W.

380. On solid solution in minerals; III, The constant composition of albite: Am. Jour. Sci., 4th ser., vol. 36, pp. 47-50, July, 1913.

381. On solid solution in minerals; IV, The composition of amorphous minerals as illustrated by chryscolla: Am. Jour. Sci., 4th ser., vol. 36, pp. 180-184, August, 1913.

Foote, Warren M.

382. Factors in the exchange value of meteorites: Am. Philos. Soc., Proc., vol. 52, pp. 516-542, September-October, 1913.

Ford, W. E., and Bradley, W. M:

383. Pyroxmangite, a new member of the pyroxene group and its alteration product, skemmatite: Am. Jour. Sci., 4th ser., vol. 36, pp. 169-174, 2 figs., August, 1913; Zeitschr. Kryst. Min., Bd. 53, H. 3, pp. 225-235, 2 figs., 1913.

Describes pyroxmangite, a new member of the pyroxene group, and its decomposition product, skemmatite, from near Iva, Anderson County, South Carolina.

384. On hetærolite from Leadville, Colorado: Am. Jour. Sci., 4th ser., vol. .35, pp. 600-604, June, 1913; Zeitschr. Kryst. Min., Bd. 53, H. 3, pp. 219-224, 1913.

Describes the characters and composition of hetroltte from Iseadville, Colo.

Foster, William.

385. A remarkable carbonaceous deposit near Putnam, New Mexico: Econ. Geology, vol. 8, no. 4, pp. 360-368, 1913.

Fowle, F. E.

Volcanoes and climate. See Abbot and Fowle, no. 2. 
Frech, Fritz.

386. Über die paläozoische Geographie des arktischen Amerikas: Intern.

Geol. Cong., XI; Stockholm 1910, Compt. rend., pp. 757-75s, 1912.

Discusses the Paleozoic geography of arctic North America.

387. Fossilium catalogus; I, Animalia, Pars 1, Ammoneæ Devonicæ (Clymeniidæ, Aphyllitidæ, Gephyroceratidæ, Cheiloceratidæ). 42 pp. Berlin, W. Junk, 1913.

Free, E. E.

388. Progress in potash prospecting in Railroad Valley, Nevada: Min. and Sci. Press, vol. 107, pp. 176-178, 1 fig., August 2, 1913.

389. The geology of the Cahuilla Basin [California] (abstract): Carnegie Inst. Washington, Yearbook no. 12, pp. 59-60, 1913.

Fry, William H.

390. Sections of two Michigan salt wells: Jour. Geology, vol. 21, no. 4, pp. 320-322, 1913.

391. Log of well of Pennsylvania Salt Company, Detroit, Mich.: Jour. Geology, vol. 21, no. 7, p. 671, October-November, 1913.

The microscopic determination of soil-forming minerals. See McCaughey and Fry, no. 718.

Gale, Hoyt $\mathrm{S}$.

392. The origin of colemanite deposits: U. S. Geol. Survey, Prof. Paper 85-A, pp. 3-9, August 11, 1913.

393. The search for potash in the desert basin region: U. S. Geol. Survey, Bull. 530, pp. 295-312, 7 figs. (incl. map and sections), 1913.

Borax; magnesite. See Yale and Gale, no. 1346.

Galloway, C. F. J.

394. Report on the coal mensures of the Peace River canyon: British Columbia, Minister of Mines, Ann. Rept. 1912, pp. 118-136, 4 pls. and 4 figs. (incl. maps), 1913.

Ganong, W. F.

395. Notes on the natural history and physiography of New Brunswick: Nat. Hist. Soc. New Brunswick, Bull., no. 30, (vol. 6, pt. 5), pp. 419451, 3 pls. (maps), 2 figs., 1913.

Gardner, James $\mathrm{H}$.

396. Field and office methods in the preparation of geologic reports; a special plane table for work on a large scale base map: Econ. Geology, vol. 8, no. 5, pp. 495-499, 1 fig., 1913.

Garrey, G. H.

Study of a contact-metamorphic ore deposit, the Dolores mine, at Matahuala, S. L. P., Mexico (abstract). See Spurr, Garrey, and Fenner, no. 1099.

Geijsbeek, Samuel.

397. The clay deposits of Oregon: Am. Ceramic Soc., Trans., vol. 15, pp. 644-658, 1 map, 1913.

George, R. D.

398. Common minerals and rocks, their occurrence and uses: Colorado State Geol. Survey, Bull. 6, 406 pp., 5 pls., 55 figs., 1913.

The minerals described in this book have not been included in the list of minerals described on p. 163.

399. Geological relations in the Brush Creek region [Colorado]; Min. Sci., vol. 67, pp. 148-149, I fig. (map), March 6, 1913. 
Gibson, 'Thomas W.

400. Report of the Bureau of Mines, 1913: Ontario, Bureau of Mines, Twentysecond Ann. Rept., vol. 22, pt. 1, 284 pp., illus., Toronto, 1913.

A statistical review with accompanying papers. These have been listed under their respective authors.

Gidel, M. H.

Mineral associations at Butte, Montana. See Bard and Gidel, no. 39.

Gidley, James William.

401. Notice of the occurrence of a Pleistocene camel north of the Arctic Circle: Smithsonian Misc. Coll., vol. 60, no. 26, 2 pp., March 21, 1913.

402. An extinct American eland: Smithsonian Misc. Coll., vol. 60, no. 27, 3 pp., 1 pl., March 22, 1913.

Describes Taurotragus americanus $n$. sp. from Pletstocene cave deposits near Cumberland, Md.

403. A recently mounted Zeuglodon skeleton in the United States National Museum: U. S. Nat. Mus., Proc., vol. 44, pp. 649-654, 2 pls., 3 figs., April 30, 1913.

404. Preliminary report on a recently discovered Pleistocene cave deposit near Cumberland, Maryland: U. S. Nat. Mus., Proc., vol. 46, pp. 93-102, 16 figs., August 23, 1913.

Gilbert, Chester G., and Pogue, Joseph E.

405. The Mount Lyell copper district of Tasmania: U. S. Nat. Mus., Proc., vol. 45, pp. 609-625, 4 pls., July 22, 1913.

Includes a brief account of the copper deposits of Shasta County, California, and Ducktown, Tennessee.

Gill, A. C.

406. Conventional position of monoclinic crystals; a question in crystallographic usage: Science, new ser., vol. 37, pp. 628-629, April 25, 1913.

Gillette, Halbert Powers.

407. Osmosis as a factor in ore formation [reprinted from Am. Inst. Min. Eng., Trans., vol. 34, pp. 710-714, 1904]. In Emmons, S. F., Ore deposits, pp. 450-454, published by the American Institute of Mining Engineers, New York, 1913.

Gilmore, Charles W.

408. A new dinosaur from the Lance formation of Wyoming: Smithsonian Misc. Coll., vol. 61, no. 5, 5 pp., 5 figs., May 24, 1913.

Describes Thescelosaurus neglectus n. gen. and n. sp.

Glenn, L. C.

409. The general features of the Tennessee coal field north of the Tennessee.

Central Railroad: 'Tennessee State Geol. Survey, Resources of Tennessee, vol. 3, no. 1, pp. 4-25, 3 figs. (incl. map and sections), January, 1913. [Also published in Bulletin 2-B.]

Goldthwait, James Walter.

410. Glacial cirques near Mount Washington: Am. Jour. Sci., 4th ser., vol. 35,

pp. 1-19, 5 figs., January, 1913.

Discusses the evidences of the former existence of local glaciers in the Presidential Range of the White Mountains, New Hampshire. 
Goldthwait, James Walter-Continued.

- 411. Following the trail of ice sheet and valley glacier on the Presidential Range: Appalachia, vol. 13, no. 1, pp. 1-23, 8 pls., May, 1913.

Describes physiographic features in the White Mountains, New Hampshire.

412. Excursion in eastern Quebec and the maritime provinces; physiography (pp. 16-24); Quebẹc and vicinity, physiographical notes (pp. 48-51) ; Rivière du Loup, the postglacial marine submergence ( $\mathrm{pp}$. 66-67); Bic, the postglacial marine submergence (pp. 77-79) ; Chàleur Bay, physiographic note (pp. 119-120): Intern. Geol. Cong., Twelfth, Guide Book no. 1 (issued by the Canada Geol. Survey), 1913.

413. The upper marine limit at Montreal : Intern. Geol. Cong., Twelfth, Guide Book no. 3 (issued by the Canada Geol. Survey), pp. 119-122, map, 1913.

414. The upper marine limit at Covey Hill and vicinity : Intern. Geol. Cong., Twelfth, Guide Book no. 3 (issued by the Canada Geol. Survey), pp. 122-126, 1913. '

415. Glacial cirques near Mount Washington (abstract and discussion by Frank Leverett, H. F. Reid, and J. B. Woodworth): Geol. Soc. America, Bull., vol. 24, no. 4, pp. 677-678, December 23, 1913.

See also Leverett, no. 686.

González, P., jr.

Exploración de la parte central elevada de la porción norte de la Península de la Baja California. S See Flores and González, no. 376.

Gordon, C. H.

416. Geology and underground waters of the Wichita region, north central Texas: U. S. Geol. Survey, Water-Supply Paper 317, 88 pp., 2 pls. (incl. map), 1913.

417. Types of iron-ore deposits in Tennessee: Tennessee State Geol. Survey, 'The Resources of Tennessee, vol. 3, no. 2, pp. 84-95, 4 figs., April, 1913.

418. Earthquakes in east Tennessee: Seismol. Soc. America, Bull., vol. 3, no. 4, pp. 191-194, 1 fig. (map), December, 1913.

Gordon, J. M.

419. Classification of coals: Canadian Min. Jour., vol. 34, pp. 524-527, August 15, 1913.

Gould, Charles N.

420. Petroleum in the red beds [Oklahoma] : Econ. Geology, vol. 8, no. 8, pp. 768-780, December, 1913.

Includes discussion of the character, occurrence, age, origin, and economic possibilities of the red beds of Kansas-Oklahoma-'Texas and consideration of the oil of northeastern Oklahoma.

421. The occurrence of petroleum and natural gas in the mid-continent field: Intern. Geol. Cong., Twelfth, Canada, 8 pp., 1913 (advance copy).

Gow, James Ellis.

422. Preliminary note on the so-called loess of southwestern Iowa (abstract) : Science, new ser., vol. 38, p. 241, August 15, 1913. 
Grabau, Amadeus W.

423. Über die Einteilung des nordamerikanischen Silurs: Intern. Geol. Cong., XI, Stockholm, 1910, Compt. rend., pp. 979-995, 6 figs., 1912.

Discusses the classification of Silurian and Ordovician of North Ameriça.

424. Continental formations in the North American Paleozoic: Intern. Geol. Cong., XI, Stockholm, 1910, Compt. rend., pp. 997-1.003, 1912.

425. Principles of stratigraphy. 1185 pp., 263 figs. New York, A. G. Seiler: and Company, 1913.

426. The origin of salt deposits with special reference to the Siluric salt deposits of North America (with discussion): Min. and Metal: Soc. America, Bull. no. 57 (vol. 6, no. 2), pp. 33-44, February 28, 1913.

427. Early Paleozoic delta deposits of North America: Geol. Soc. America, Bull., vol. 24, no. 3, pp. 399-528, 12 figs., 1 pl., September, 1913.

428. Paleontological notes; 1 , polyphyletic genera; 2 , an illustration of Waagen's theory of mutations (abstract): Geol. Soc. America, Bull., vol. 24, no. 1, p. 109, March 24, 1913.

429. Was there a former Goat Island at Niagara Falls? (abstract) : New York Acad. Sci., Annals, vol. 22, p. 37S, April 20, 1913.

430. Irrational stratigraphy; the right and wrong way of reconstructing ancient continents and seas (abstract) : Science, new ser., vol. 38, p. 282, August 22, 1913.

431. A classification of marine deposits (abstract, and discussion by J. Barrell) : Geol. Soc. America, Bull., vol. 24, no. 4, pp. 711-714, December 23, 1913.

432. Glacial erosion in the Genesee Valley system and its bearing on the 'Tertiary drainage problem of eastern North America (abstract, and discussion by J. W. Spencer) : Geol. Soc. America, Bull., vol. 24, no. 4, pp. 718-719, December 23, 1913.

See also Gregory, no. 440, and Wright, no 1342.

Graham, R. P. D.

On the crystallization of willemite. See Palache and Graham, no. 875.

Grammer, F. L.

433. The laws of jointing (discussion) : Am. Inst. Min. Lng., Bull. no. 83, p. 2692, November, 1913.

Grant, U. S., and Higgins, D. F.

434. Coastal glaciers of Prince William Sound and Kenai Peninsula, Alaska:

U. S. Geol. Survey, Bull. 526, 75 pp., 40 pls., 18 figs., 1913.

Graton, L. C.

435. Investigation of copper enrichment: Eng. and Min. Jour., vol. 96, pp. S85-SS7, November \&, 1913.

436. Ore deposits at Butte, Montana (discussion) : Am. Inst. Min. Eng., Bull. no. 83, pp. 2735-2736, November, 1913.

Graton, L. C., and Murdoch, Joseph.

437. The sulphide ores of copper; some results of microscopic study (with discussion by James F. Kemp, Horace V. Winchell, and L. C. Graton ) : Am. Inst. Min. Eng., Bull. no. 77, pp. 741-811, 36 figs., May, 1913.

Gray, Francis William.

438. The coal-fields and the coal-industry of eastern Canada : Inst. Min. Eng.

(England), Trans., vol. 46, pt. 1, pp. 23-60, 7 figs., 1913. 
Green, Wyman R.

439. A description of the specimens of the teleostean genus Enchodus in the University of Kansas Museum: Kansas, Univ., Sci. Bull., vol. 7, no. 2, pp. 71-107, 17 pls., 1913.

Gregory, Herbert E.

440. The Shinarump congiomerate: Am. Jour. Sci., 4th ser., vol. 35, pp. 424438, 1 fig., April, 1913 (abstract, with discussion by A. W. Grabau and N. H. Darton), Geol. Soc. America, Bull., vol. 24, no. 4, pp. 679-680, December 23, 1913.

441. Preliminary geological map of the Navajo-Moki reservation (abstract) : Geol. Soc. America, Bull., vol. 24, no. 4, p. 680, December 23, 1913.

Gregory, W. M.

442. Geological report on Arenac county: Michigan Geol. and Biol. Survey, Pub. 11, Geol: series S, 146 pp., 6 pls., 18 figs., 1912.

\section{Gregory, William K.}

443. Relations of the Tupaiidæe and of Eocene lemurs, especially Notharctus (abstract) : Geol. Soc. America, Bull., vol. 24, no. 1, p. 117, March 24, 1913.

444. Homology of the "alisphenoid" and "lachrymal" in recent and fossil vertebrates (abstract) : Geol. Soc. America, Bull., vol. 24, no. 1, p. 118, March 24, 1913.

445. Crossopterygian ancestry of the Amphibia: Science, new ser., vol. 37, pp. 806-808, May 23, 1913.

446. Homology of the "lacrimal" and of the "alisphenoid" in recent and fossil reptiles: Geol. Soc. America, Bull., vol. 24, no. 2, pp. 241-246, June 9, 1913.

447. Relationship of the Tupaiidæ and of Eocene lemurs, especially Notharctus: Geol. Soc. America, Bull., vol. 24, no. 2, pp. 247-252, June 9, 1913.

Griffith, Wm.

448. Approximate columnar sections showing the co-relation of anthracite coal beds of Pennsylvania: Colliery Engineer, vol. 34, no. 3, supplement, October, 1913.

Grout, Frank F.

449. On the behavior of cold acid sulphate solutions of copper, silver, and gold with alkaline extracts of metallic sulphides: Icon. Geology, vol. .8, no. 5, pp. 407-433, 1913.

Grout, F. F., Worcester, P. G., and Henderson, Junius.

450. Reconnaissance of the geology of the Rabbit Ears region, Routt, Grand, and Jackson counties: Colorado State Geol. Survey, Bull. 5, pt. 1, pp. 1-57, 2 pls. (geol. map and section), 1913.

Gunter, Herman.

Artesian water supply of eastern and southern Florida. See Sellards and Gunter, no. 1038.

Guppy, R. J. Lechmere.

451. Observations on the geology of Martinique with notes on fossils from Trinidad and Venezuela: Agr. Soc. Trinidad and Tobago, Proc., vol. 13, pt. 4, pp. 159-163, April, 1913.

Gutiérrez Lanza, R. P. Mariano.

452. Conferencias de seismología [lectures on seismology]: Acad. Cienc. Méd., Fís., Nat., Habana, Anales, Rev. cient., t. 50, pp. 164-230, Julio, 1913. 
Haanal, Eugene.

Summary report of the Mines branch of the Department of Mines for the calendar year ending December 31, 1.912. See no. 174.

Haarmann, Erich.

453. Geologische Streifzüge in Coahuila: Deutsche Geol. Gesell., Zeitschr., Bd. 65, Monatsber., no. 1, pp. 18-47, 16 figs., 1913.

Gives various geologic data on the State of Coahuila, Mexico.

Hadley, Arthur T.

454. James Dwight Dana centenary; introductory remarks: Geol. Soc. America, Bull., vol. 24, no. 1, pp. 55-56, March 24, 1913.

Hafer, Claud.

455. Pyrophyllite in North Carolina: Eng. and Min. Jour., vol. 96, pp. 623625, 3 figs., October 4, 1913.

Hager, Dorsey.

456. Anticlinal dome structure in California oil fields: Western Eng, vol. 3, no. 3, pp. 196-199, 4 figs., September, 1913.

Hahn, F. Felix.

457. Untermeerische Gleitung bei Trenton Falls (Nordamerika) und ihr Verb:iltnis zu :ihnlichen Störungsbildern: Neues Jahrb., Beilage Bd. 36, H. 1, pp. 1-41, 3 pls., 15 figs., 1913.

Describes submarine slide at Trenton Falls, New York, and similar deformation phenomena.

Hall, Archibald A.

458. Analysis of a Floridil clay: Durham, Univ., Philos. Soc., vol. 4, pp. 228-229, 1912.

Haltenberger, Michael.

459. On a genetic system of sand dunes, including two new types: Am. Geog. Soc., Bull., vol. 45, pp. 513-515, 2 pls., July, 1913.

Hance, J. H.

460. The Coaldale coal field, Esmeralda County, Nevada: U. S. Geol. Survey, Bull. 531, pp. 313-322, 1. pl. (map), 1 fig., 1913.

461. Notes on the occurrence of different varieties of clay: U. S. Geol. Survey, Mineral Resources, 1912, pt. 2, pp. 608-620, 1913.

Hanna, G. Dallas, and Johnston, Edward C.

462. A Pleistocene molluscan fauna from Phillips County, Kansas: Kansas, Univ., Sci. Bull., vol. 7, no. 3, pp. 111-121, 1 pl., 1913.

Hannibal, Harold.

The marine Tertiary stratigraphy of the north Pacific coast of

America. See Arnold and Hannibal, no. 18.

Harrington, G. L.

A comparison of waters of mines and of hot springs. See Emmons and Harrington, no. 361.

Harris, G. D.

463. Immense salt concretions: Pop. Sci. Monthly, vol. \$2, pp. 187-191, 1913.

Hartley, Burton.

464. Field and office methods in the preparation of geologic reports; fleld methods in the "Tierra Caliente": Econ. Geology, vol. 8, no. 6, pp. 578-581, 1 fig., September, 1913. 
Hartzell, J. Culver.

465. The value of geochemistry to geology and geography (abstract) : Science, new ser., vol. 37, p. 458, March 21, 1913.

Harvie, Robert.

466. Asbestos deposits of the Province of Quebec: Intern. Geol. Cong., Twelfth, Guide Book no. 2 (issued by the Canada Geol. Survey), pp. 99-117, maps, figs., 1913.

Haskell, Daniel C.

467. A partial bibliography of Niagara Falls: New York (State), Commissioners of the State Reservation at Niagara, 29th Ann. Rept., pp. 49-98, 1913.

Hastings, John B.

468. Are the quartz veins of Silver Peak, Nevada, the result of magmatic segregation? [reprinted from Am. Inst. Min. Eng., Trans., vol. 36, pp. 647-654, 1906]. In Emmons, S. F., Ore deposits, pp. 621628, 1 fig., published by the American Institute of Mining Engineers, New York, 1913.

Haultain, H. E. T.

469. The geologist: Canadian Min. Jour., vol. 34, pp. 182-185, March 15, 1913.

Hawkins, Alfred C.

470. Some interesting mineral occurrences at Princeton, N. J.: Am. Jour. Sci., 4th ser., vol. 35, pp. 446-450, 3 figs., April, 1913.

Hay, Oliver $\mathbf{P}$.

471. Notes on some fossil horses, with descriptions of four new species: U. S. Nat. Mus., Proc., vol. 44, pp. 569-594, 5 pls., 28 figs., April $30,1913$.

472. Description of the skull of an extinct horse, found in central Alaska: Smithsonian Misc. Coll., vol. 61, no. 2, 18 pp., 2 pls., 8 figs., June 4, 1913.

473. The extinct bisons of North America; with description of one new species, Bison regius: U. S. Nat. Mus., Proc., vol. 46, pp. 161-200, 10 figs., 12 pls., December 6, 1913.

474. Camels of the fossil genus Camelops: U. S. Nat. Mus., Proc., vol. 46, pp. 267-277, 1 fig., 2 pls., December $6,1913$.

Haynes, Winthrop P.

475. Discovery of bivalve Crustacea in the coal measures near Pawtucket, Rhode Island: Science, new ser., vol. 37, pp. 191-192, 2 figs., January 31, 1913.

Heap, R. R.

476. A geological drainage problem: Eng. and Min. Jour., vol. 96, pp. 12051211, 5 figs., December 27, 1913.

Includes a brief account of the geology of the Miami lead and zinc district in southwestern Missouri.

Heim, Arnold.

477. Lava-fields of the Kilauea, Hawaii: Geologische Charakterbilder (H. Stille), Heft 16, 8 pls. and explanatory text, 1913. 
Henderson, Junius.

478. Geology and topography of the Rio Grande region in New Mexico: Smithsonian Inst., Bur. Am. Ethnology, Bull. 54, pp. 23-39, 8 pls., 1913.

Reconnaissance of the geology of the Rabbit Ears region, Routt, Grand, and Jackson counties [Colorado]. See Grout, Worcester and Henderson, no. 450.

Hennen, Ray V., and Reger, David B.

479. [Report on the history and physiography, geology; and mineral resources of] Marion, Monongalia, and Taylor counties: West Virginia Geol. Survey, 844 pp., 33 pls., 11 figs., 3 maps (under separate cover), 1913.

Henning, Karl L.

480. Die Red Beds; ein Beitrag zur Geschichte der bunten Sandsteine: Geol. Rundschau, Bd. 4, pp. 228-244, 1 fig., June, 1913.

Herald, Frank A.

481. The Williston lignite field, Williams County, North Dakota: U. S. Geol. Survey, Bull. 531, pp. 91-157, 2 pls. (map and sections), 1913.

Heroy, W. B.

482. Land classification; its basis and methods: Econ. Geology, vol. 8 , no. 4, pp. 337-359, 1913.

Hershey, Oscar H.

483. Origin of lend, zinc, and silver in the Cœu d'Alene [Idaho]: Min. and Sci. Press, vol. 107, pp. 489-493, 529-533, September 27 and Octo. ber 4, 1913.

Hess, Frank L.

484. Vanadium in the Sierra de los Caballos, New Mexico: U. S. Geol. Survey, Bull. 530, pp. 157-160, 1913.

485. Carnotite near Green River, Utah: U. S. Geol. Survey; Bull. 530, pp. 161-164, 1913.

486. Notes on the vanadium deposits near Placerville, Colorado: U. S. Geol. Survey, Bull. 530, pp. 142-156, 4 figs., 1913.

487. A sulphur deposit in the San Rafael Canyon, Utah: U. S. Geol. Survey, Bull. 530, pp. 347-349, 1913 .

488. Cobalt; molybdenum; nickel; tantalum; tin; titanium; tungsten; uranium and vanadium; antimony; bismuth; selenium: U. S. Geol. Survey, Mineral Resources, 1912, pt. 1, pp. 963-1045, 4 figs., 3 pls., 1913.

489. Arsenic: U. S. Geol. Survey, Mineral Resources, 1912, pt. 2, pp. 833-837, 1913.

Zirconiferous sandstone near Ashland, Virginia. See Watson and Hess, no. 1246.

Hess, Frank L., and Hunt, W. F.

490. Triplite from eastern Nevada: Am. Jour. Sci., 4th ser., vol. 36, pp. 51-54, July, 1913; Washington Acad. Sci., Jour., vol. 3, no. 10, p. 286, May 19, 1913.

$38416^{\circ}-$ Bull. $584-14-4$ 
Hewett, D. I'.

491. Sulphur deposits of Sunlight Basin, Wyoming: U. S. Geol. Survey, Bull. 530, pp. 350-362, 1 pl. (sketch map), 1 fig. (index map), 1913.

492. Manganese and manganiferous ores: U. S. Geol. Survey, Mineral Resources, 1912, pt. 1, pp. 203-221, 1913.

493. An occurrence of petroleum near Cody, Wyoming (abstract) : Washington Acad. Sci., Jour., vol. 3, no. 2, pp. 51-52, January 19, 1913.

Hice, Richard R.

494. The geological origin of the freshwater fauna of Pennsylvania; introductory note: Pennsylvania 'Topog. and Geol. Survey, Rept. 1910-1912, pp. 130-134, 1 fig., 1912.

Discusses drainage changes.

495. The mineral production of Pennsylvania : Pennsylvania Topog. and Geol. Survey, Rept. 1910-1912, pp. 156-177, 20 figs., 1912.

Higgins, D. F.

496. The plane table in geologic mapping with especial reference to graphic horizontal control by intersection methods: Econ. Geology, vol. 8, no. 8, pp. 729-751, 10 figs., December, 1913.

Coastal glaciers of Prince William Sound and Kenai Peninsula, Alaska. See Grant and Higgins, no. 434.

Higgins, Will C.

497. The American Ozokerite Company: Utah, State Inspector of Mines, Sth Bienn. Rept., 1911-1912, pp. 130-141, 5 pls., 1913.

Includes notes on the occurrence of ozokerite near Colton, Utah.

Hill, Belle.

498. Natural gas: U. S. Geol. Survey, Mineral Resources, 1912, pt. 2, pp. 301-359, 1913.

Hill, James M.

499. Notes on the northern La Sal Mountains, Grand County, Utah: U. S. Geol. Survey, Bull. 530, pp. 99-118, 1 fig., 1913.

Describes the geologic features and the occurrence of gold deposits.

500. The zinc-lead deposits of the Yellow Pine district, Nevada (abstract) : Washington Acad. Sci., Jour., vol. 3, no. 8, pp. 238-239, April 19, 1913.

501. Rarytes; mineral paints: U. S. Geol. Survey, Mineral Resources, 1912, pt. 2, pp. 955-984, 1913.

Hill, Robert T.

502. The coal fields of Mexico: The Coal Resources of the World, XII Intern. Geol. Cong., Canada, 1913, vol. 1, pp. lxv-lxvii, vol. 2, pp. 553-559, 1913.

Hillebrand, W. F.

503. A danger to be guarded against in making mineral separations by means of heavy solutions: Am. Jour. Sci., 4th ser., vol. 35, pp. 439-440, April, 1913; Washington Acad. Sci., Jour., vol. 3, no. 5, pp. 137-138, March 4, 1913; Zeitschr. Kryst. Min., Bd. 53, H. 1, pp. 1-3, 1913.

Hillebrand, W. F., and Merwin, H. E.

504. Two varieties of calciovolborthite (?) from eastern Utah: Am. Jour. Sci., 4th ser., vol. 35, pp. 441-445, April, 1913; Washington Acad. Sci., Jour., vol. 3, no. 5, p. 138, March 4, 1913; (abstract), vol. 3, no. 20, p. 503, December 4, 1913 ; Zeitschr. Kyrst. Min., Bd. 53, H. 1, pp. 4-9, 1913. 
Hillebrand, W. F., Wright, Fred. T., and Merwin, H. E.

505. Calcium vanadates from Peru, Colorado, and Utah: Washington Acad. Sci., Jour., vol. 3, no. 6, pp. 157-158, March 19, 1913.

Hills, V. G.

506. A tungsten mine in Nova Scotia: Min. and Sci. Press, vol. 106, pp. 448-450, 2 figs., March 22, 1913.

Hintze; Ferdinand Friis, jr.

507. A contribution to the geology of the Wasatch Mountains, Utah: New York Acad. Sci., Annals, vol. 23, pp. $85-143,6$ pls., 5 figs., December 12, 1913.

Hobbs, William Herbert.

508. Some considerations concerning the place and origin of lava maculæ: Beiträge zur Geophysik (Gerland), Bd. 12, H. 2, pp. 329-361, 8 figs., 1913 ; (abstract), Michigan Acad. Sci., 14th Rept., p. 1.07, 191.2.

509. Soil flow: Am. Geog. Soc., Bull,, vol. 45, pp. 281-284, April, 1913.

510. Variations in composition of pelitic sediments in relation to magmatic differentiation: Intern. Geol. Cong., 'Twelfth, Canada, 5 pp., 1913 (advance copy).

Hobson, $\mathrm{B}$.

511. The Twelfth International Geological Congress in Canada: Geol. Mag., new ser., dec. 5 , vol. 10 , no. 11 , pp. $486-490$, November, 1913.

Holden, Edwin C.

512. The mineral industry of Wisconsin: Wisconsin Engineer, vol. 17, no. 4, pp. 158-173, January, 1913.

Holden, Ruth.

513. Cretaceous Pityoxyla from Cliffwood, New Jersey: Am. Acad. Arts and Sci., Proc., vol, 48, no. 16, pp. 609-624, 4 pls., March, 1913.

514. Some fossil plants from eastern Canada: Annals Botany, London, vol, 27, pp. 243-255, 2 pls., April, 1913.

Hollick, Arthur.

515. Lester Frank Ward [1841-191.3] : Science, new ser., vol. 38, pp. 75-77, July 18, 1913.

516. Preliminary correlation of the Cretaceous and Tertiary floras of Alaska (abstract) : Geol. Soc. America, Bull., vol. 24, no. 1, p. 116, March 24, 1913.

Holt, William P.

517. The study of minerals and rocks in high school physical geography: Jour. Geography, vol. 11, pp. 188-190, February, 1913.

Holtedahl, Olaf.

518. The Cambro-Ordovician beds of Bache Peninsula and the neighboring regions of Ellesmere Land: Second Norwegian Arctic Expedition in the "Fram" 1898-1902, Rept. (published by Videnskabs-Selskabet i Kristiania), no. 28, 14 pp., 1 map, 4 pls., 1913.

\section{Holway, Ruliff S.}

519. The Russian River, a characteristic stream of the California coast ranges: California, Univ., Publications in Geog., vol, 1, no. 1, pp. 1-60, 11 pls., 1 fig., April 8, 1913.

A physiographic study of the river. 
Hore, Reginald E.

520. The outlying cobalt-silver areas [Ontario]; townships of Casey and Harris; area south of Lake Wendigo: Ontario, Bureau of Mines, Rept., vol. 19, pt. 2, pp. 145-148, 149-151, 2 figs. (including map), 1913.

521. Gold deposits of Porcupine district, Ontario: Econ. Geology, vol. 8, no. 5 , pp. $482-488,1913$.

522. Cobalt conglomerate [Ontario] : Min. Mag., vol. 8, no. 1, p. 43, January, 1913.

523. Silver deposits of the Cobalt district, Ontario, Canada: Mexican Min. Jour., vol. 16, no. 4, pp. 178-181, 5 figs., April, 1913.

524. The Coniagas mine, Cobalt, Ontario: Eng. and Min. Jour., vol. 95, no. 19, pp. 981-982, 3 figs., May 17, 1913.

525. Kirkland Lake gold deposits [Ontario]: Canadian Min. Jour., vol. 34, pp. 424-431, 18 figs. (incl. map), July 15, 1913.

526. On the origin of the Porcupine gold deposits: Canadian Min. Jour., vol. 34, pp. 54S-551, September 1, 1913.

Hornaday, W. D.

527. The Juan Casiano oil field, State of Vera Cruz, Mexico: Min. and Eng. World, vol. 3S, p. 100, January 1S, 1913.

Hovey, Edmund Otis.

528. Proceedings of the twenty-fifth annual meeting of the Geological Society of America, held at New Haven, Connecticut, December 28, 29, 30, and 31, 1912: Geol. Soc. America, Bull., vol. 24, no. 1, pp. 1-90, 4 pls., March 24, 1913 .

529. Abstracts of papers presented at the twenty-fifth annual meeting of the society, but not published in full in the preceding pages of this volume, together with discussions of papers as far as preseived: Geol. Soc. America, Bull., vol. 24, no. 4, pp. 669-719, December 23, 1913.

530. Dana, the teacher: Geol. Soc. America, Bull., vol. 24 , no. 1, pp. 60-64, March 24, 1913.

Howe, Ernest.

531. Landslides and the sinking of ground above mines: Intern. Geol. Cong., Twelfth, Canada, 3 pp., 1913 (advance copy).

See also Day and Shepherd, no. 300.

Howley, James P.

532. The coal deposits of Newfoundland: The Coal Resources of the World, XII Intern. Geol. Cong., Canada, 1913, vol. 1, p. lxi, vol. 2, pp. 431-438, 1 map in text, 1913.

Hubbard, George D.

sal

533. Gas and oil wells near Oberlin, Ohio: Econ. Geology, vol. 8 , no. 7, pp. 681-690, 1 fig., October, 1913; (abstract), Science, new ser., vol. 37, pp. 458-459, March 21, 1913.

534. Evidence of very early glaciation in Ohio (abstract): Geol. Soc. America, Bull., vol. 24, no. 4, pp. 696-697, December 23, 1913.

Hudson, George H.

535. The use of the stereogram in paleobiology: New York State Mus., Bull. 164 , pp. 103-130, 13 pls., 1913.

536. Does the type of Protopalcaster narrawayi present an oral or aboral aspect?: Ottawa Naturalist, vol. 27 , pp. $77-84,2$ pls., 1 fig., October, 1913. 
Hudson, Joseph G. S.

537. Sections of the Sydney coal fields, Cape Breton, Nova Scotia: Canada, Dept. Mines, Mines Branch, 6 pp., 4 tables, 1.5 pls., 1 map, 1913.

Huene, Freidrich von.

538. A new phytosaur from the Palisades near New York: Am. Mus. Nat. Hist., Bull., vol. 32, pp. 275-2\$2, 2 pls., 14 figs., 1913.

539. The skull elements of the Permian Tetrapoda in the American Museum of Natural History, New York: Am. Mus. Nat. Hist., Bull., vol. 32, pp. 31.5-386, 57 figs., 1913.

Humphreys, W. J.

540. Volcanic dust and other factors in the production of climatic changes, and their possible relation to ice ages: U. S. Dept. Agr., Mount Weather Observatory, Bull., vol. 6, pt. 1. (W. B. no. 51.1), 34 pp., 5 figs., August 20, 1913; Franklin Inst., Jour., vol. 176, no. 2, pp. 131-172, 5 figs., August, 1913; Washington Acad. Sci., Jour., vol. 3, no. 13, pp. 365-371, July 1.9, 1913.

Volcanic dust in the upper regions of the atmosphere is presented as a cause of ice ages.

Hunt, W. F.

Two vanadiferous agirites from Tibby, Montana. See Larsen and Hunt, no. 659 .

Triplite from enstern Nevada. See Hess and Hunt, no. 490.

Hunter, J. Fred.

Two sulphur deposits in Mineral County, Colorado. See Larsen and Hunter, no. 660 .

Huntingtun, Ellsworth.

541. Bearing of recent climatic investigations on geological theories (abstract, with discussion by W. N. Rice, C. W. Brown, and A. L. Day ) : Geol. Soc. America, Bull., vol. 24, no. 4, pp. 687-68s, Decem- . ber $23,1913$.

Huntley, L. C.

Petroleum and natural gas resources of Canada. See Clapp and Huntley, no. 203.

Hussakof, L.

542. Descriptions of four new Paleozoic fishes from North America: Am. Mus. Nat. Hist., Bull., vol. 32, pp. 245-250, 1 pl., 2 figs., 191.3.

Hyde, J. I.

543. Excursion in eastern Quebec and the maritime provinces; character and fauna of the Riversdale and Union formations (p. 221) ; annotated guide, Truro to Campbell's siding (pp. 222-225) ; the Carboniferous sections on Sydney Harbour (pp. 251-262) : Intern. Geol. Cong., Twelfth, Guide Book no. 1. (issued by the Canada Geol. Survey), 1913.

Iddings, Joseph $\mathbf{P}$.

544. Igneous rocks; composition, texture and classification, description and occurrence. In two volumes. Vol. II, $\mathrm{xi}, 685 \mathrm{pp}$., 20 figs., 8 maps. New York, John Wiley \& Sons, 1913.

The rocks described and the chemical analyses have not been included in the lists on pages 162 and 164 of this bibliography. 
Ingalsbe, F. R.

545. The Cœur d'Alene mining district [Idaho] : Eng. and Min. Jour., vol. 96, pp. 156-159, July 26, 1913.

\section{International Geological Congress.}

546. Guide book, nos. 1-10. Issued by the Geological Survey of Canada and the Ontario Bureau of Mines [for the Twelfth International Geological Congress]. Ottawa, 1913.

The papers, descriptive of the regions to be visited in the excursions, have been listed under the individual authors.

Irving, J. D.

547. [Geologic field methods] (editorial): Lcon. Geology, vol. 8, no. 1, pp. 64-65, January, 1.913.

548. The substructure of geological reports: Econ. Geology, vol. S, no. 1, pp. 66-96, January, 1913.

Irving, J. D., Smith, H. D., and Ferguson, H. G.

549. A selected list of the more important contributions to the investigation of the origin of metalliferous ore deposits: In Emmons, S. F., Ore deposits, pp. 837-846, published by the American Institute of Mining Engineers, New York, 1913.

Jackson, Robert Tracy.

550. Alpheus Hyatt and his principles of research: Am. Naturalist, vol. 47, pp. 195-205, portrait, April, 1913; (abstract) Geol. Soc. America, Bull., vol. 24, no. 1, p. 1.05, March 24, 1913.

Jandorf, Morton Lehmayer.

551. Preliminary report on the York Valley limestone belt in York County: Pennsylvania 'Topog. and Geol. Survey, Rept. 1910-1912, pp. 50129, 14 pls. (incl. maps), 1912.

552. Copper in York County, Pennsylvania: Min. and Sci. Press, vol. 106, pp. 346-347, March 1, 1913.

Jeffrey, Edward C.

553. Inadequacy of the sapropelic hypothesis of the origin of coal (abstract) : Geol. Soc. America, Bull., vol. 24, no. 4, p. 706, December 23, 1913.

554. Nature of the substance known as mother of coal and its relation to the process of coal formation (abstract): Geol. Soc. America, Bull., vol. 24, no. 4, pp. 715-716, December 23, 1913.

Jenney, Walter $P$.

555. The chemistry of ore deposition (with discussion by J. A. Church) [reprinted from Am. Inst. Min. Eng., Trans., vol. 33, pp. 445-498, 1065-1070, 1903]. In Emmons, S. F., Ore deposits, pp. 305-363, published by the American Institute of Mining Engineers, New . York, 1913.

Jenning, Henry.

The mechanical and chemical composition of the soils of the Sussex area, New Jersey. See Blair and Jenning, no. So.

Jennings, E. P.

A titaniferous iron ore deposit in Boulder County, Colo.: Am. Inst. Min. Eng., Trans., vol. 44, pp. 14-25, 8 figs., 1913. 'See no. 544 of the bibliography for 1912, U. S. Geol. Survey, Bull. 545. 
Jennings, $\mathrm{O}$. $\mathrm{E}$.

556. Note on the geology of the Isle of Pines, Cuba: Jour. Geology, vol. 21, no. 4 , pp. $367-369,1.913$.

Jessup, D. W.

557. Ore deposits of the Prince Consolidated mines: Min. and Sci. Press, vol. 106, pp. 773-775, 3 figs., May 24, 1913.

Describes the geology of the Ely mining district, Nevada, and the character and structural relations of the ore deposits.

Joerg, Wolfgang L. G.

558. On the proper map for determining the location of earthquakes: Assoc. Am. Geog., Annals, vol. 2, pp. 49-54, 1 pl. [1913].

Johannsen, Albert.

559. An accessory lens for observing interference figures of small mineral grains: Jour. Geology, vol. 21, no. 1, pp. 96-98, January-February, 1913.

Johnson, B. L.

Mineral deposits of the Ellamar district [Alaska]. See Capps and Johnson, no. 178.

Johnson, Douglas W.

560. Submarine Chamæcyparis bog at Woods Hole, Massachusetts, and its relation to the problem of coastal subsidence (abstract): Geol. Soc. America, Bull., vol. 24, no. 4, pp. 699-700, December: 23, 1913.

561. Botanical phenomena and the problem of recent coastal subsidence: Bot. Gazette, vol. 56, no. 6, pp. 449-468, 9 figs., December, 1913.

562. The shore line of Cascumpeque Harbor, Prince Edward Island (abstract) : Science, new ser., vol. 37, p. 958, June 20, 1913.

See also Spencer, no. 1092.

Johnson, Henry R.

563. Geologic notes on Santa Susanna district [Ventura Co., California]: Western Eng., vol. 2, no. 5, pp. 383-386, 2 figs., May, 1.913.

Johnston, Edward C.

A Pleistocene molluscan fauna from Phillips County, Kansas. See Hanni and Johnston, no. 462.

Johnston, John.

564. Note on the temperature in the deep boring at Findlay, Ohio: Am. Jour. Sci., 4th ser., vol. 36, pp. 131-134, 1 fig., August, 1913; (abstract), Washington Acad. Sci., Jour., vol. 3, no. 20, p. 500, December 4, 1913 .

Johnston, John, and Adams, L. H.

565. Iffect of high pressures on the physical and chemical behavior of solid substances (abstract and discussion by H. F. Reid and A. L. Day) : Geol. Soc. America, Bull., vol. 24, no. 4, pp. 674-675, December 23, 1913.

Johnston, John, and Niggli, Paul.

566. The general principles underlying metamorphic processes: Jour. Geology, vol. 21, no. 6, pp. 481-516, no. 7, pp. 588-624, 4 figs., 1913.

Johnston, Robert A. A.

567. Prehnite from Adams Sound, Admiralty Inlet, Baffin Island, Franklin: Canada Geol. Survey, Victoria Memorial Mus., Bull. no. 1, pp. 95-98, October 23, 1913. 
Johnston, W. A.

568. Algonquin Beach, glacial phenomena and Lowville (Ordovician) limestone in Lake Simcoe diștrict, Ontario: Intern. Geol. Cong., Twelfth, Guide Book no. 5 (issued by the Canada Geol. Survey), pp. 23-35, 2 pls., 1913.

The superficial deposits near Ottawa. See Keele and Johnston, no. 582.

Jones, Charles Colcock.

569. The discovery and opening of a new phosphate field in the United States: Am. Inst. Min. Eng., Bull. no. 82, pp. 2411-2435, 13 figs., October, 1913.

Describes phosphate deposits in northeastern Utah, southeastern Idaho, and western Wyoming.

Jones, E. L., jr.

Geology of the St. Joe-Clearwater region, Idaho. See Calkins and Jones, no. 164.

Jones, J. Claude.

570. The Barth iron ore deposit: Econ. Geology, vol. 8, no. 3, pp. 247-263, 5 figs., 1913; (abstract), Geol. Soc. America, Bull., vol. 24, no. 1, pp. 96-97, March 24, 1913.

Describes the local geology and the occurrence, character, and origin of the iron deposits near Barth, Nev.

571. Geology of Rochester, Nevada: Min. and Sci. Press, vol. 106, pp. 737738, 1. fig. (map), May 17, 1913.

Describes the geology and the character and occurrence of ore deposits.

572. Origin of travertine or tufa deposits of Salton Sink [California] (abstract) : Carnegie Inst. Washington, Yearbook no. 12, pp. 60-61. 1913.

Jongmans, W.

573. Fossilium catalogus; II, Plantæ, Pars 1, Lycopodiales I. 52 pp. Berlin, W. Junk, 1913.

Gives synonymy, horizon, and locality. Includes American forms.

Jordan, David Starr, and Beal, Carl Hugh.

574. Supplementary notes on fossil sharks: California, Univ., Dept. Geology, Bull., vol. 7, no. 11, pp. 243-256, 1 fig., April 25, 1913.

Julien, Alexis A.

575. Alteration processes and products within the Grenville limestone (abstract) : Geol. Soc. America, Bull., vol. 24, no. 4, pp. 717-718, December 23, 1913.

Kaemmerer, Paul.

576. Versuch zu einer neuen Deutung der Struktur des Meteoreisens von Carthage ('Tennessee) : Centralbl. Mineralogie, no. 1, pp. 17-25, 6 figs., January 1., 1913.

Describes the structure of a meteorite from Carthage, Tenn.

577. Weitere Studien über die Struktur des Meteoreisens von Carthage (Tennessee) : Centralbl. Mineralogie, no. 9, pp. 261-269, 6 figs., May 1., 1913.

Describes the structure of a meteorite from Carthage, Tenn. 
Katz, Frank J.

578. Preliminary report on the geology of the Portland and Casco Bay quadrangles: Maine, State Water Storage Comm., 3d Ann. Rept., pp. 170-184, 1913.

579. Clay in the Portland region, Maine: U. S. Geol. Survey, Bull. 530, pp. 202-206, 1 fig. (map), 1913.

580. Abrasive materials; feldspar and quartz: U. S. Geol. Survey, Mineral Resources, 1.912, pt. 2, pp. 819-831, 1007-1015, 1913.

Detailed description of the Fairbanks district. See Prindle and Katz, no. 931 .

Kay, George F.

581. The American Association for the Advancement of Science; Section EGeology and Geography: Science, new ser., vol.' 37, pp. 456-460, March 21, 1913.

Keele, Joseph, and Johnston, W. A.

582. The superficial deposits near Ottawa: Intern. Geol. Cong., Twelfth, Guide Book no. 3 (issued by the Canada Geol. Survey), pp. 126-135, 1913.

Keith, Arthur.

583. Further discoveries in the Taconic Mountains (abstract): Geol. Soc. America, Bull., vol. 24, no. 4, p. 680 , December 23, 1913.

584. Producţion of apparent diorite by metamorphism (abstract) : Geol. Soc. America, Bull., vol. 24, no. 4, pp. 684-685, December 23, 1913.

Kellogg, L. O.

585. Notes on the Cuyuna Range, I: Eng. and Min. Jour., vol. 96, pp. 111991203, 6 figs., December 27, 1913.

Includes notes on the geology of the iron ores of the Cuyuna Range, Minnesota.

Kelly, Clyde, and Anspach, E. V.

586. A preliminary study of the waters of the Jemez Plateau, New Mexico:

New Mexico, Univ., Bull., Chem. Ser., vol. 1, no. '1, pp. 1-73, September, 1913.

Includes notes on the geology and the springs.'

Kelton, F. C.

Geology and water resources of Sulphur Spring Valley, Arizona. See Meinzer and Kelton, no. 785.

Kemp, James Furman.

587. The future of the iron industry, especially in North America: Intern. Geol. Cong., XI, Stockholm 1910, Compt. rend., pp. 321-328, 1912.

588. Pre-Cambrian formations in the State of New York: Intern. Geol. Cong., XI, Stockholm 1910, Compt. rend., pp. 699-719, 1. fig. (map), 1912.

589. Igneous rocks and circulating waters as factors in ore deposition [reprinted from Am. Inst. Min. Eng., Trans., vol. 33, pp. 699-714, 1903]. In Emmons, S. F., Ore deposits, pp. 235-250, published by the American Institute of Mining Engineers, New York, 191.3.

590. The copper deposits at San Jose, Tamaulipas, Mexico [reprinted from Am. Inst. Min. Eng., Trans., vol. 36, pp. 178-203, 1906]. In Emmons, S. F., Ore deposits, pp. 557-581, 3 figs., published by the American Institute of Mining Engineers, New York, 1913. 
Kemp, James Furman-Continued.

591. Field and office methods in the preparation of geological reports (discussion); geological field methods: Econ. Geology, vol. 8, no. 2, pp. 171-176, 1 fig., March, 1913.

592. The ground-waters: Am. Inst. Min. Eng., Bull. no. 76, pp. 603-624, April, 1913.

593. Artificial vein formation in the Tomboy mill, Telluride, Colorado: Econ. Geology, vol. 8, no. 6, pp. 543-550, 4 figs., September, 1913.

594. Contact zones (discussion) : Econ. Geology, vol. 8, no. 6, pp. 597-610, September, 1913.

595. Water in veins : Min. and Sci. Press, vol. 107, pp. 938-939, December 13, 1913.

596. The influence of depth on the character of metalliferous deposits: Intern. Geol. Cong., Twelfth, Canada, 8 pp., 1913 (advance copy); Canadian Min. Jour., vol. 34, pp. 543-546, September 1, 1913; (abstract), Min. and Eng; World, vol. 39, pp. 591-593, October 4, 1913.

See also Day and Shepherd, no. 300; Graton and Murdoch, no. 437 ; and Woodman, no. 1323.

Kew, W. S. W., and Stoner, R. C.

597. Monterey series on the south side of Mount Diablo, California (abstract) : Geol. Soc. America, Bull., vol. 24, no. 1, p. 129, March 24, 1913.

Keyes, Charles $\mathbf{R}$.

598. Wind-graved mesas and their message: Pop. Sci. Monthly, vol. 81, no. 3 , pp. 227-237, 8 figs., September, 1912.

599. Critical criteria on basin-range structure: Science, new ser., vol. 37, p. 226, February 7, 1913.

600. Great erosional work of winds: Pop. Sci. Monthly, vol. 82, no. 5, pp. 468-477, 9 figs., May, 1913.

601. Annotated bibliography of Iowa geology and mining: Iowa Geol. Survey, vol. 22, 908 pp., 1913.

602. Original streams; and their rôle in general desert-leveling: Jour. Geology, vol. 21, pp. 268-272, 1913.

603. Antigravitátional gradation: Science, new ser., vol. 38, p. 206, August 8, 1913.

604. Marked unconformity between Carboniferous and Devonian strata in upper Mississippi Valley: Am. Jour. Sci., 4th ser., vol. 36, pp. 160164, 1 fig., August, 1913.

605. W J McGee, geologist, anthropologist, hydrologist: Annals of Iowa, $3 d$ ser., vol. 11 , no. $2-3$, pp. $180-187,1$ pl. (port.), July-October, 1913.

606. Certain features of eolic gradation: Intern. Geol. Cong., Twelfth, Canada, 5 pp., 1913 (advance copy).

607. Angular amphitheaters of the Grand Canyon (abstract) : Science, new ser., vol. 37, pp. 457-458, March 21, 1913.

608. Geologic significance of enisled relief (abstract): Science, new ser., vol. 37, p. 458, March 21, 1913.

609. Iowan Cretacic sequence (abstract) : Science, new ser., vol. 38, p. 241, August 15, 1913.

610. Terranal differentiation of Devonic succession in Iowa (abstract): Science, new ser., vol. 38, p. 241, August 15, 1913.

611. Possible occurrence of Tertiary deposits east of the Missouri River (abstract) : Science, new ser., vol. 38, p. 241, August 15, 1913. 
Keyes, Charles R.-Continued.

612. Magnitude of continental deposits (abstract): Geol. Soc. America, Bull., vol. 24, no. 4, p. 677 , December 23, 1913.

613. Certain so-called meteoric irons of Canyon Diablo (abstract): Geol. Soc. America, Bull., vol. 24, no. 4, pp. 685-686, December 23, 1913.

Kindle, Edward M.

614. Systematic paleontology of the Middle Devonian deposits of Maryland; Vermes, Ostracoda: Maryland Geol. Survey, Middle and Upper Devonian, pp. 122, 335-33s, 2 pls., 1913.

615. Note on a process of fossilization in the Paleozoic lycopods: Geol. Mag., dec. 5, vol. 10, pp. 337-340, 1 pl., 1 fig., August, 1913; (abstract), Geol. Soc. America, Bull., vol. 24, no. 1, pp. 115-116, March 24, 1913.

616. The unconformity at the base of the Onondaga limestone in New York and its equivalent west of Buffalo: Jour. Geology, vol. 21, no. 4, pp. 301-319, 8 figs., 1913.

617. The Onondaga fauna of the Allegheny region (abstract) : Washington Acad. Sci., Jour., vol. 3, no. 14, pp. 403-404, August 19, 1913.

618. The age of the eurypterids of Kokomo, Indiana: Am. Jour. Sci., 4ti ser., vol. 36, pp. 2S2-2s8, September, 1.913.

Systematic paleontology of the Middle Devonian deposits of Maryland; Brachiopoda, Pelecypoda, Gastropoda, Cephalopoda, Trilobita. See Prosser and Kindle, no. 935.

The Middle Devonian deposits of Maryland. See Prosser, Kindle, and Swartz, no. 937.

Kindle, E. M., and Taylor, Frank B.

619. Description of the Niagara quadrangle [New York]: U. S. Geol. Survey, Geol. Atlas U. S., Niagara folio (no. 1.90), 25 pp., 25 pls., 4 maps, 16 figs., 1913.

Kithil, Karl $L$.

620. On the occurrence of a probable new mineral: Science, new ser., vol. 38, pp. 624-625, October 31, 1913.

A preliminary report on uranium, radium, and vanadium. See Moore and Kithil, no. 835 .

Klopstock, Paul.

621. The Kennedy mining district, Nevada: Am. Inst. Min. Eng., Bull. no. 78, pp. 1041-1.046, June, 1913; Min. and Eng. :World, vol. 39, pp. 63-65, July 12, 1913.

Includes notes on the local geology and the character and occur-

Klotz, Otto. rence of the ores yielding chiefly gold.

622. Earthquake of April 28, 1913: Canada, Dept. Interior, Dominion Observatory, Ottawa, Pub., vol. 1, no. 5, pp. 131-152, 1 chart, 1 map, 1913.

623. The undagraph: Seism. Soc. America, Bull., vol. 3, no. 1, pp. 20-23, 1, pl., March, 1913.

Knight, Cyril w.

624. The outlying cobalt-silver areas [Ontario]; Montreal River and Temagami forest reserve: Ontario, Bureau of Mines, Rept., vol. 19, pt. 2, pp. 155-164, 6 figs. (including map), 1913.

625. The Madoc area [Ontario]: Intern. Geol. Cong., Twelfth, Guide Book no. 6 (issued by the Ontario Bur. Mines), pp. 55-62, 2 maps, 9 pls., 1913.

Sudbury, Cobalt, and Porcupine geology [Ontario]. See Miller and Knight, no. 819 . 
Knopf, Adolph.

626. Ore deposits of the Helena mining region, Montana: U. S. Geol. Survey, Bull. 527, 143 pp., 7 pls. (incl. maps), 4 figs., 1913.

Describes the stratigraphy and the occurrence and character of gold, silver, lead, and copper deposits.

627. The tourmalinic silver-lead type of ore deposit: Econ. Geology, vol. 8, no. 2, pp. 105-119, March, 1913.

628. A magmatic sulphide ore body at Elkhorn, Montana: Econ. Geology, vol. 8, no. 4, pp. 323-336, 3 figs., 1913.

629. The fineness of gold in the Fairbanks district, Alaska (discussion): Econ. Geology, vol. 8, no. 8, pp. 800-802, December, 1913.

630. The Eagle River region, southeastern Alaska (abstract): Washington Acad. Sci., Jour., vol. 3, no. 9, pp. 258-259, May 4, 1913.

Knopf, Adolph, and Umpleby, J. B.

631. Recent literature on economic geology: Econ. Geology, vol. 8, no. 2, pp. 193-203, March, 1913.

Knowlton, F. H.

632. Results of a paleobotanical study of the coal-bearing rocks of the Raton Mesa region of Colorado and New Mexico: Am. Jour. Sci., 4th ser., vol. 35, pp. 526-530, May, 1913; (abstract), Geol. Soc. America, Bull., vol. 24, no. 1, p. 114, March 24, 1913; (abstract), Washington Acad. Sci., Jour., vol. 3, no. 6, pp. 173-174, March $19,1913$.

633. Description of a new fossil fern of the genus Gleichenia from the upper Cretaceous of Wyoming: U. S. Nat. Mus., Proc., vol. 45, pp. 555-558, 1 pl., 1913.

634. The fossil forests of Arizona : Am. Forestry, vol. 19, no. 4, pp. 207-218, 8 pls., April, 1913.

635. Memoir of W J McGee: Geol. Soc. America, Bull., vol. 24, no. 1, pp. 18-29, 1 pl. (port.), March 24, 1913.

Includes a list of his writings.

The relations of paleobotany to geology : Smithsonian Inst., Ann. Rept. for 1912, pp. 353-358, 1913. Reprinted from the American Naturalist, vol. 46 , pp. 207-215, 1912.

Kramm, H. E.

636. Excursion in eastern Quebec and the maritime provinces; the Hillsborough gypsum deposit (pp. 363-367): Intern. Geol. Cong., Twelfth, Guide Book no. 1 (issued by the Canada Geol. Survey), 1913.

Kraus, Edward H.

637. Die Aenderungen des optischen Axenwinkels im Glauberit mit der Temperatur: Zeitschr. Kryst. Min., Bd. 52, H. 4, pp. 321-371, 1 fig., 1913.

Discusses variations of the optic angle of axis in glauberite with temperature.

Kraus, E. H., and Cook, C. W.

638. Die Kristallformen des Jodyrits von Tonopah, Nevada: Centralbl. Minérálogie, no. 13, pp. 385-386, July 1, 1913.

Kraus, E. H., and Youngs, L. J.

639. Some interesting changes in the optical properties of crystals with temperature (abstract) : Michigan Acad. Sci., 14th Rept., p. 108, 1912. 
Krebs, C. E., and Teets, D. D., jr.

640. Cabell, Wayne, and Lincoln counties [West Virginit]: West Virginia Geol. Survey, County Repts., 483 pp., 3 maps (in atlas), 26 pls., 6 figs., 1913.

Krusch, P.

641. Primary and-secondary ores considered with especial reference to the gel and the rich heavy metal ores: Min. and Sci. Press, vol. 107, pp. 41S-423, September 13, 1913.

Kümmel, Henry B.

642. Annual administrative report of the State geologist for the year 1.912 : New Jersey Geol. Survey, Bull. 8, pp. 7-35, 1913.

La Forge, Laurence, and Phalen, W. C.

643. Description of the Ellijay quadrangle [Georgia-North Carolina-Tennessee] : U. S. Geol. Survey, Geol. Atlas U. S., Ellijay folio (no. 187), 18 pp. 4 pls. (maps), 7 figs., 1913.

Describes physiographic features, the distribution, character, and relations of pre-Cambrian and Cambrian rocks, and post-Cambrian igneous rocks, the geologic history, and the mineral resources, including gold, copper, iron, manganese, marble, and others.

Lahee, Frederic H.

644. Geology of the new fossiliferous horizon and the underlying rocks, in Littleton, New Hampshire: Am. Jour. Sci., 4th ser., vol. 36, pp. 231-250, 9 figs. (incl. map), September, 1913.

Lakes, Arthur.

645. The coal fields of western Canada: Colliery, Engineer, vol. 34, no. 1, pp. 11-14, 1 fig. (map), August, 1913.

Lamb, H. Mortimer.

646. General index together with summaries of papers contained in vols. I to X, inclusive (1898-1907) of the Journal of the Ganadian Min. Inst., 488 pp., Montreal, January, 1913.

647. Willet G. Miller: Canadian Min. Jour., vol. 34, p. 695, 1 fig. (port.); November 15, 1913.

Lambe, Lawrence $M$.

648. The occurrence of helodont teeth at Roche Miette and vicinity, Alberta: Canada Geol. Survey, Victoria Memorial Mus., Bull. no. 1, pp. 17-20, 1 pl., 1 fig., October 23, 1913.

649. The manus in a specimen of Trachodon from the Edmonton formation of Alberta: Ottawa Naturalist, vol. 27, pp. 21-25, 3 pls., May, 1913.

650. Description of a new species of 'Testudo, and of a remarkable specimen of Stylemys nebrascensis, from the Oligocene of Wyoming: Ottawa Naturalist, vol. 27, pp. 57-63, 4 pls., 1 fig., August-September, 1913.

651. A new genus and species of Ceratopsia from the Belly River formation of Albertal: Ottawa Naturalist, vol. 27, no. 9, pp. 109-116, 3 pls., December, 1913.

Lane, Alfred C.

652. The stratigraphic value of the "Laurentian": Intern. Geol. Cong., XI, Stockholm, 191.0, Compt. rend., pp. 633-637, 1 fig., 1912.

653. Meteor dust as a measure of geologic time: Science, new ser., vol. 37, pp. 673-674, May 2, 1913.

654. Michigan, its physiography: The Gateway, vol. 19, no. 6, pp. 23-28, vol. 20, no. 3, pp. 16-22, 11 figs., January and April, 1913. 
Lane, Alfred C.-Continued.

655. The age of the Keweenawan series (abstract): Michigan Acad. Sci., 14th Rept., pp. 107-108, 1912.

656. Origin of granites as well as metacrystals by selective solution-a recantation (abstract, with discussion by G. P. Merrill) : Geol. Soc. America, Bull., vol. 24, no. 4, p. 704, December 23, 1913.

657. New light on the Keweenawan fault (abstract): Geol. Soc. America, Bull., vol. 24, no. 4, p. 718, December 23,:1913.

Larsen, Esper S.

658. Alunite in the San Cristobal quadrangle, Colorado: U. S. Geol. Survey, Bull. 530, pp. 179-183, 1913.

A preliminary report on the geology and ore deposits of Creede, Colorado. See Emmons and Larsen, no. 362.

The hot springs and the mineral deposits of Wagon Wheel Gip, Colorado. See Emmons and Larsen, no. 363.

Custerite; a new contact metamorphic mineral. See Umpleby, Schaller, and Larsen, no. 1197.

Larsen, Esper S., and Hunt, W. F.

659. Two vanadiferous ægirites from Libby, Montana: Am. Jour. Sci., 4th ser., vol. 36, pp. 289-296, 2 figs., September, 1913; Zeitschr. Kryst. Min., Bd. 53, H. 3, pp. 209-218, 2 figs., 1913.

Describes the occurrence, associations, characters, and composition of vanadiferous ægirite and ægirite-augite from the Rainy Creek mining district, near Libby, Lincoln County, Mont.

Larsen, Esper S., and Hunter, J. Fred.

660. Two sulphur deposits in Mineral County, Colorado: U. S. Geol. Survey, Bull. 530, pp. 363-369, 1913.

Larsh, Paul A.

661. Lucky Bill lead-vanadium mine [Grant County, New Mexico] : Eng. and Min. Jour., vol. 96, pp. 1103-1105, 2 figs., December 13, 1913.

Lawson, Andrew C.

662. The petrographic designation of alluvial fan formations: California, Univ., Dept. Geology, Bull., vol. 7, no. 15, pp. 325-334, June 12, 1913.

663. The gold of the Shinarump at Paria [Utah]: Econ. Geology, vol. 8, no. 5, pp. 434-448, 5 figs., 1913.

Describes stratigraphic and physiographic features in the vicinity of Paria and discusses the gold content of the Shinarump clay.

664. Gold and coal mines of Nova Scotia: Min. and Metal. Soc. America, Bull. no. 65, vol. 6, pp. 281-283, October 31, 1913.

665. A standard scale for the pre-Cambrian rocks of North America: Intern. Geol. Cong., Twelfth, Canada, 23 pp., 1913 (advance copy).

Report of the committee on the nomenclature of faults. See Reid and others, no. 967 .

See also Martin, no. 749, and Taff, no. 1144.

Leach, W. W.

666. Burmis, Alberta, to Elko, British Columbia:: Intern.' Geol. 'Cong., Twelfth, Guide Book no. 9 (issued by the Canada Geol. Survey), pp. 22-46, maps, pls., 1913.

The coal resources of the world. See McInnes, Dowling, and Leach, no. 733 . 
Lee, Charles H.

667. Use and conservation of the underground reservoirs of California: Western Eng., vol. 3, no. 3, pp. 189-194, September, 1913.

Lee, Willis Thomas.

668. Stratigraphy of the coal lands of northern central New Mexico. Thesis, Johns Hopkins University (reprinted from Bulletin of the Geological Society of Americi, vol. 23). Baltimore, 1913.

669. Graphite near Raton, New Mexico: U. S. Geol. Survey, Bull. 530, pp. 371-374, 1913.

670. The Cerrillos coal field, Santa Fe County, New Mexico: U. S. Geol. Survey, Bull. 531, pp. 285-312, 3 pls. (maps and sections), 2 figs., 1913.

Describes the general geology, the conl-bearing rocks, the quality of the coal, and the distribution, relations, and correlation of the coal beds.

671. Recent discovery of dinosaurs in the Tertiary : Am. Jour. Sci., 4th ser., vol. 35, pp. 531-534, May, 1913; (abstract), Washington Acad. Sci., Jour., vol. 3, no. 6, p. 173, March 19, 1913.

672. Coal fields of Grand Mesa and the West Elk Mountains (abstract) : Washington Acad. Sci., Jour., vol. 3, no. 12, pp. 362-363, June 19, 1.913.

Leffingwell, $\mathrm{E}$. de $\mathrm{K}$.

673. A reconnaissance of the Arctic slope of Alaska (abstract) : Washington Acad. Sci., Jour., vol. 3, no. 11, pp. 343-344, June 4, 1913.

Leighton, Morris M.

674. An exposure showing post-Kansan glaciation near Iowa City, Iowa: Jour. Geology, vol. 21, no. 5, pp. 431-435, 2 figs., 1913.

Leith, C. K.

675. A summary of Lake Superior geology with special reference to recent studies of the iron-bearing series [reprinted in part from Am. Inst. Min. Eng., Trans., vol. 36, pp. 101-153, 1906]. In Emmons, S. F., Ore deposits, pp. 633-656, 1 sketch map, 4 figs., published by the American Institute of Mining Engineers, New York, 1913.

676. Structural geology. 169 pp., 68 figs. New York, Henry Holt and Company, 1913.

677. "Algonkian" vs. "pre-Cambrian": Econ. Geology, vol. 8, no. 5, pp. 507-508, 1913.

Leonard, Arthur Gray.

678. The geological map of North Dakota: North Dakota, Univ., Quart. Jour., vol. 4, no. 1, pp. 3-13, 1 mıр, 5 pls., October, 1.91 .3$.

679. Bismarck, N. Dak., folio (abstract by Wm. C. Alden) : Washington Acad. Sci., Jour., vol. 3, no. 18, pp. 466-467, November 4, 1913.

LeRoy, O. E.

680. West Kootenay and Boundary districts: Intern. Geol. Cong., Twelfth, Guide Book no. 9 (issued by the Canada Geol. Survey), pp. 61-102, maps, pls., 1913.

Lett, Stephen J.

681. The occurrence of gold in Ontario (discussion) : Inst. Min. and Met., Bull. no. 111, pp. 46-47, December 11, 1913. 
Leverett, Frank.

682. Field and office methods in the preparation of geologic reports; field methods of glacial geology : Econ. Geology, vol. 8, no. 6, pp. 581588, September, 1913.

683. Correlation of Lake Agassiz with glacial lakes in Great Lakes basins (abstract) : Michigan Acad. Sci., 14th Rept., p. 115, 1912.

684. Time relations of glacial lakes in the Great Lakes region (abstract) : Washington Acad. Sci., Jour., vol. 3, no. 8 pp. 237-238, April 19, 1913.

685. Beginnings of Lake Agassiz (abstract): Geol. Soc. America, Bull., vol. 24, no. 4, p. 697, December, 1913.

686. Remarkable deformation of the Algonquin Beach (abstract, with discussion by J. W. Goldthwait) : Geol. Soc. America, Bull., vol. 24, no. 4, p. 697, December 23, 1913.

687. Iowan drift (abstract, with discussion by A. P. Coleman) : Geol. Soc. America, Bull., vol. 24, no. 4, pp. 698-699, December 23, 1913.

See also Goldthwait, no. 415 .

Levison, Wallace Goold.

688: Illustrations of mineral associations by means of color plate and other photographs of opaque specimens (abstract) : New York Acald. Sci., Annals, vol. 22, pp. 356-357, April 20, 1913.

Lewis, J. Volney.

689. Determinative mineralogy, with tables for the determination of minerals by means of their chemical and physical characters. $151 \mathrm{pp}$., 68 figs. New York, John Wiley \& Sons, 1913.

See also Cushing, no. 273.

Lincoln, Francis Church.

690. The quantitative mineralogical classification of gradational rocks: Econ. Geology, vol. 8, no. 6, pp. 551-564, September, 1913.

Lincoln, Francis Church, and Rietz, Henry Lewis.

691. The determination of the relative volumes of the components of rocks by mensuration methods: Econ. Geology, vol. 8, no. 2, pp. 120-139, March, 1913.

Lindeman, Einar.

692. Austin Brook iron-bearing district, New Brunswick: Canada, Dept. Mines, Mine Branch, 15 pp., 3 pls., 5 figs., 3 maps (in pocket), 1913.

693. Magnetite occurrences along the Central Ontario-Railway: Canada, Dept. Mines, Mines Branch, 23 pp., 9 pls., 19 maps (under separate cover), 1913.

694. Moose Mountain iron-bearing district, Ontario: Canada, Dept. Mines, Mines Branch, Summ. Rept. 1912, pp. 83-85, 1913.

Lindgren, Waldemar.

695. The geological features of the gold production of North America (with discussion by W. G. Miller and W. L. Austin) [reprinted from Am. Inst. Min. Eng., Trans., vol. 33, pp. 790-811. (Part III omitted), 1077-1083, 1903]. In Emmons, S F., Ore deposits, pp: 424-449, published by the American Institute of Mining Engineers, New York, 1913.

696. The genesis of the copper deposits of Clifton-Morenci, Arizona [reprinted from Am. Inst. Min. Eng., Trans., vol. 35, pp. 511-550, 1905]. In Emmons, S. F., Ore deposits, pp. 517-556, published by the American Institute of Mining Engineers, New York, 1913. 
Lindgren, Waldemar-Continued.

697. The occurrence 'of stibnite at Steamboat Springs, Nevada [reprinted from Am. Inst. Min. Eng., Trans., vol. 36, pp. 27-31, 1906]. In Emmons, S. F., Ore deposits, pp 629-632, published by the American Institute of Mining Engineers, New York, 1913.

698. Mineral deposits. xv, 883 pp., illus. New York, McGraw-Hill Book Company, 1913.

Contributions to economic geology (short papers and preliminary reports), 1911. Part I. Metals and nonmetals, except fuels. See U. S. Geological Survey, no. 1199.

See also Stevens, no. 1109.

Lindsey, G. G. S.

699. Muskoka lakes [Ontario]: Intern. Geol. Cong., Twelfth, Guide Book no. 6 (issued by the Ontario Bur. Mines), pl. 43-48, 2 figs. (maps), 1913.

Linforth, Frank A.

700: Applied geology in the Butte mines: Am. Inst. Min. Fng., Bull. no. 83, pp. 2611-2623, 6 figs., November, 1913.

Linton, Robert.

701. Texas iron ore deposits: Eng. and Min. Jour., vol. 96, pp. 1153-1156, 6 figs. (including map), December 20, 1913.

Iloyd, E. Russell.

Recent literature on economic geology. See Paige and Lloyd, no. S73.

Lord, N. W., and others.

702. Analyses of coals in the United States with descriptions of mine and field samples collected between July 1, 1904, and June 30, 1.910: U. S. Bur. Mines, Bull. 22, 1200 pp., 1913.

Louderback, George Divis.

703. The Monterey series in California: California, Univ., Dept. Geology, Bull., vol. 7, no. 10, pp. 177-241, February 26, 1913.

704. Proceedings of the thirteenth annual meeting of the Cordilleran section. of the Geological Society of America, held at Stanford University, California, April 5, 1912: Geol. Soc. America, Bull., vol. 24, no. 1, pp. 91-98, March 24, 1913.

705. General features of the structure of the bedrock complex of the Sierra Nevada (abstract) : Geol. Soc. America, Bull., vol. 24, no. 1, p. 98, March 24, 1913.

Loughlin, Gerald Francis.

706. Reconnaissance in the southern Wasatch Mountains, Utah: Jour. Geology, vol. 21, no. 5, pp. 436-452, 4 figs., 1913 ; (abstract), Washington Acad. Sci., Jour., vol. 3, no. 2, pp. 50-51, January 19, 1913.

Louis, Henry.

707. The allotropism of gold [reprinted from Am. Inst. Min. Eng., Trans., vol. 24, pp. 182-186, 1895]. In Emmons, S. F., Ore deposits, pp. 105-109, published by the American Institute of Mining Engineers, New York, 1913.

$38416^{\circ}-$ Bull. $584-14-5$ 
Lull, Richard Swann.

708. Glacial man: Yale Review, vol. 1, no. 3, pp. 376-389, April, 1912.

709. The Yale collection of fossil horses: Yale Univ., Coll., no. 1, 12 pp., 12 figs., February 21, 1913.

710. The Yale expedition of 1912 (abstract): Geol. Soc. America, Bull., vol. 24 , no. 1, p. 117, March 24, 1913.

Notes the vertebrate fossils obtained from the Panhandle region of Texas.

L̇upton, Charles T.

711. Gypsum along the west flank of the San Rafael Sivell, Utah: U. S. Geol. Survey, Bull. 530, pp. 221-231, 1 pl. (map), 1913.

INcCallie, s. W.

712. A preliminary report on the mineral springs of Georgia: Georgia Geol. Survey, Bull. no. 20, 190 pp., 24 pls. and map, 1913.

713. Outlook for the gold-mining industry of Georgia: Min. and Eng. World, vol. 38, pp. 22-23, 2 figs., January 4, 1913,

714. The ocher deposits of Georgia : Colliery Engineer, vol. 33, no. 1, pp. 4647, 2 figs., August, 1912.

MacCallum, A. P.

715. Origin of chalcocite : Eng. and Min. Jour., vol. 96, pp. 893-\$94, November $8,1913$.

IMcCaskey, H. D.

716. Precious and semiprecious metals in 1912 : U. S. Geol. Survey, Mineral Resources, 1912, pt. 1, pp. 225-273, 417-436, 1913.

717. Quicksilver: U. S. Geol. Survey, Mineral Resources, 1912, pt. 1, pp. 931948, 1913.

McCaughey, W: J., and Fry, William $\mathrm{H}$.

718. The microscopic determination of soil-forming minerals: U. S. Dept. Agr., Bur. Soils, Bull. no. 91, 100 pp., 12 figs., 1913.

McConnell, R. G.

719. Prince Rupert and Skeena River (pp. 5-35) ; Granby Bay, Observatory Inlet (pp. 162-168) : Intern. Geol. Cong., Twelfth, Guide Book no. 10 (issued by the Canada Geol. Survey), maps, pls., 1913.

MacDonald, Donald Francis.

720. Slides in the Culebra cut at Panama : Eng. Record, vol. 66, pp. 22S-233, 6 figs., August 31, 1912.

Includes notes on the geological conditions.

721. Geology of Culebra cut; nature and conduct of slides: Canal Record, vol. 6, p. 88, November 6, 1912.

722. Notes on the gold lodes of the Carrville district, Trinity County, California: U. S. Geol. Survey, Bull. 530, pp. 9-41, 1 pl. (map), 9 figs., 1913.

723. Geology of the Isthmus [of Panama] : Canal Record, vol. 6, pp. 213-215, February 26, 1913.

724. Geology of western Panama; Chiriqui Volcano: Canal Record, vol. 6, p. 4.24, August 6, 1913.

725. Earthquakes and the Panama Canal; a study of the geological conditions on the Isthmus and what it reveals: Sci. Am., vol. 109, pp. 303-305, 5 figs., October 18, 1913.

726. Geologic section of the Pinama Canal Zone (abstract): Geol. Soc. America, Bull., vol. 24, no. 4, pp. 707-711, December 23, 1913.

727. Excavation deformations: Intern. Geol. Cong., Twelfth, Canada, 13 pp., 3 figs., 1913 (advance copy). 
McDonald, P. B.

728. Mining in northern New York: Eng. and Min. Jour., vol. 95, no. 14, pp. 689-692, 4 figs. (incl, geol. map), April 5, 1913.

Includes notes on the geology and economic minerals.

729. Applied geology, Michigan iron ranges: Eng. and Min. Jour., vol. 96, pp. 208-210, 8 figs., August 2, 1913.

MacFarlane, Graham.

730. Clinton iron-ore deposits in Kentucky and Tennessee (discussion) : Am. Inst. Min. Eng., Trans., vol. 44, p. S89, 1913.

IMcGee, W J.

731. Wells and subsoil water: U. S. Dept. Agr., Bur. Soils, Bull. no. 92, 185 pp., 1913.

Machatschek, Fritz.

732. Jungvulkanische Erscheinungen in den westlichen Gebirgen der amerikanischen Union: Deutsch. Rundschau für Geogr., Jg. 35, H. 7, pl. 289-300, 6 figs., 1913.

Discusses various volcanic phenomena of recent geologic ages in mountainous regions of the Western States.

MIcInnes, William, Dowling, D. B., and Leach, W. W., elitors.

733. The coal resources of the world, ... XII International Geological Congress, Canadi, 1913. 3 vols., 1266 pp., maps and figs., in text, and atlas of 48 maps. Toronto, Canada, Morang \& Co., 1913.

McIntosh, D. S.

734. Note on recent earthquake in Cape Breton: Nova Scotian Inst. Sci., Proc. and Trans., vol. 12, pt. 4, pp. 311-312, August 30, 191.3:

Maclaren, Malcolm.

735. The persistence of ore in depth: Intern. Geol. Cong., Twelfth, Canada, 9 pp., 1913 (advance copy).

MacLean, A.

736. Ordovician and Silurian of Stony Mountain and Stonewall, Manitobil (pp. 69-77) ; Calgary to Winnipeg via Cauadian Northern Railway (pp. 349-370) : Intern. Geol. Cong., 'Jwelfth, Guide Book no. S (issued by the Canada Geol. Survey), maps, 1913.

IMacLean, 'I. A.

737. Lode mining in Yukon; an investigation of quartz deposits in the Klondike division: Canada, Dept. Mines, Mines Branch, Summ. Rept. 1912, pp. 121-139, 5 pls., 2 folded maps, 1913.

McLeish, John.

738. Annual report on the mineral production of Canada during the calendar year 1911: Canada, Dept. Mines, Mines Branch, 216 pp., 191.8.

Maddren, A. G.

-739. The Koyukuk-Chandalar region, Alaska: U. S. Geol. Survey, Bull. 582, 119 pp., 9 pls., 2 figs., 1913.

Describes the physiographic features, the stratigraphy, including Paleozoic, Mesozoic, and Cenozoic formations, and the economic

Malcolm, Wyatt. geology, particularly the gold placers.

740. Gold fields of Nova Scotia: Canadai Geol. Survey, Mem. no. 20, 331. p1)., 42 pls., 24 figs., 2 maps, 1912.

741. Oil and gas prospects of the northwest provinces of Canada : Canada Geol. Survey, Mem. no. 29, 99 pp., 9 pls., 2 figs., 1913. 
Mansfield, G. R.

Structural features of a portion of southeast Idaho (abstract). See Richards and Mansfield, no. 973.

Bannock thrust-a major fault in southeast. Idaho. See Richards and Mansfield, no. 974 .

Manson, Marsden.

742. The significance of early and of Pleistocene glaciations: Intern. Geol. Cong., XI, Stockholm 1910, Compt. r'end., pp. 10S9-1106, 1912.

743. The evidences of interglacial periods on the Sierra Nevada Mountains, California: Intern. Geol. Cong., 'Twelfth, Canada, 3 pp., 1913 (adrance copy).

Marbut, Curtis Fletcher.

744. Geology : Missouri, Univ., Bull., Science ser., vol. 1, no. 6, pp. 125-146, April, 1913.

Marbut, Curtis F., and others.

745. Soils of the United States (edition, 1913) : U. S. Dept. Agr., Bur. Soils; Bull. no. 96, 791 pp., 2 pls., 13 figs., 1913.

Margerie, İmm. de.

746. Deux accidents cratêriformes; Crater Lake (Oregon) and Meteor Crater (Arizona): Annales de Géographie, Ann. 22, pp. 172-184, 3 figs., March 15, 1913.

Describes Crater Lake, Oregon, and Meteor Crater, Arizona.

Mark, Clara Gould.

747. The fossils of the Conemaugh formation in Ohio: Ohio Geol. Survey, $\therefore$ Fourth Series, Bull. 17, pp. 261-31s, 4. pls., 7 tables, 1912.

Martin, Bruce.

748. Geological section of a portion of the coast ranges in the eastern part of San Luis Obispo County, California (abstract): Geol. Soc. America, Bull., vol. 24, no. 1, p. 93, March 24, 1913.

749. Faunal relatións of the upper Neocene in the Sargent oil fields, California (äbstract, with discussion by A. C. Lawson, B. L. Clark, F. M. Anderson, and J. C. Merriam) : Geol. Soc. America, Bull., vol. 24, no. 1, p. 129, March 24, 1913.

Martin; George C.

750. Mineral deposits of Kodiak and the neighboring islands [Alaska]: U. S. Geol. Survey, Bull. 542, pp. 125-136, map, 1913.

751. The recent eruption of Katmai Volcano in Alaska; an account of one of the most tremendous volcanic explosions known in history: Nat. Geọg: Mag., vol. 24, no. 2, pp. 131-181, 57 figs. (including map), February, 1913.

The coal resources of Alaska. See Brooks and Martin, no. 110.

Martin, H. T.

752. On a comparison of three skulls; Castoroides olioensis, Castoroides: kansensis, and Castor: Kansas, Univ., Sci. Bull., vol. 6, no. 6, pp. 389-396, 3 pls., January, 191-2 [1913].

753. Notice of a new fish from the Permian of Kansas, with description : Kansas, Univ., Sci. Bull., vol. 7, no. 7, pp. 185-186, 1912. 
Martin; Lawrence.

754. Juneau-Yakutat section: Intern. Geol. Cong., 'Twelfth, Guide Book no. 10 (issued by the Canada Geol. Survey), pp. 121-162, maps, pls., figs., 1913.

755. Memoir of Christopher Webber Hall [1845-1911]: Assoc. Anl. Geog., Annals, vol. 2, pp. 101-104, [1913].

756. Mount Mazama and Crater Lake: Jour: Geography, vol. 11., p1. 322-324, 1 fig., June, 1913.

757. Glacier National Park: Jour. Geography, vol. 11, pp 324-326, 2 figs,, June, 1913.

758. Un chemin de fer sur glacier dans l'Alaska: La Nature, Paris, Ann. 41, pp. 404-407, 4 figs., May 23, 1013.

Includes notes on physical features of the Allen glacier across which a railroad has been built.

759. Some features of glaciers and glaciation in the College Fiord, Prince William Sound, Alaskal : Zeitschr. Gletscherkunde, Bd. 7, H. 5, pl). 289-333, 21 figs. (including maps), October, 1913.

760. Alaskan glaciers in relation to life: Am. Geog. Soc., Bull., rol. 45, 110. 11. pp. 801-\$18, 11 figs., 1 map, November, 1913.

761. Canyon and delta of the Copper River in Alaska (abstract) : Geol. Soc. America, Bull., vol. 24, no. 4, p. 699, December 23, 1913.

Glacial deposits of the continental type in Alaska. See Tarr and Nartin, no. 1146.

An effort to control a glacial stream. See Tarr and Martin, 110. 1144T.

Martin, Lawrence; Williams, F. E., and Bean, E. F.

762. A manual of physical geography excursions. $201 \mathrm{pl} ., 29$ figs. Matdison, published by the University of Wisconsin, 1913.

IVartonne, Emm. de.

763. Le Parc National du Yellowstone; étude morphologique: Annales de Gêographie, Ann. 22, pp. 134-148, 2 pls., 5 figs., March 15, 1913.

Describes physiographic features of Yellowstone National Park.

\section{Maryland Geological Survey.}

764. Devonian; Lower, Middle and Upper, and plates. 3 vols., Lower (text), 560 pp., 16 pls., 17 figs.; Middle and Upper (text), 720 pp., 6 pls., 2 figs.; plates (atlas), 156 pp., pls. 1.7-9S, 6-73. Baltimore, The Johns Hopkins Press, 1913.

Mathews, E. B. See Wright, no. 1335.

Mathews, Edward B., and Reed, G. E.

765. Bibliography of the department of geology of the Johns Hopkins University, 1.S83-1913: Johns Hopkins Univ., Circ. no. 10, 143 pp., December, 1913.

Matson, George Charlton.

766. .Notes on the clays of Delaware: U. S. Geol. Survey, Bull. 530, pi). 185$201,1913$.

767. Mineral waters: U. S. Geol. Survey, Mineral Resources, 1912, plt. 2, pp. 1093-1131, 1913.

Matson, George Charlton, and Sanford, Samuel.

768. Geology and ground waters of Florida: U. S. Geol. Survey, WaterSupply Paper 319, 445 pp., 17 pls. (incl. map, in pocket), 7 figs., 1913. 
Matthes, François E.

769. Little studies in the Yosemite Valley; IV, El Capitan moraine and ancient Lake Yosemite: Sierra Club Bull., vol. 9, no. 1, pp. 7-15, 2 figs. (incl. map), January, 1913.

770. The glaciers of Mount Rainier: Appalachia, vol. 13, no. 1, pp. 24-27, May, 1913.

771. Level of maximum precipitation as a factor in the glaciation of Mount Rainier (abstract): Geol.. Soc. America, Bull., vol. 24, no. 4, pp. 701-702, December 23, 1913.

Matthew, G. F.

772. A new flora in the older Paleozoic rocks of southern New Brunswick: Roy. Soc. Canada, Proc. and Trans., 3d ser., vol. 6, sec. 4, pp. 83-99, 2 pls., 1 fig., 1912.

773. The sudden appearance of the Cambrian fauna: Intern. Geol. Cong., XI, Stockholm, 1910, Compt. rend., pp. .547-559, 1912.

Matthew, W. D.

774. Certain theoretical considerations affecting phylogeny and correlation: Geol. Soc. America, Bull., vol. 24, no. 2, pp. 283-292, 1 fig., June 11, 1913 ; (abstract), Geol. Soc. America, Bull., vol. 24, no. 1, p. 118, March 24, 1913.

775. The laws of nomenclature in paleontology: Science, new ser., vol. 37 , pp. 788-792, May 23, 1913.

776. A zalambdodont insectivore from the basal Eocene: Am. Mus. Nat. Hist., Bull., vol. 32, pp. 307-314, 2 pls., 6 figs., 1913.

777. Nomenclature in paleontology: Science, new ser., vol. 38, pp. 87-SS, July 18, 1913.

778. American Museum expeditions for fossil vertebrates: Am. Mus. Jour., vol. 13, pp. 286-2S7, October, 1913.

779. The asphalt group of fossil skeletons: Am. Mus. Jour., vol. 13, no. 7, pp. 291-297, 6 figs., November, 1913.

Describes the Rancho La Brea deposits in southern California.

780. Cuban fossil mammals; preliminary note (abstract) : Geol. Soc. America, Bull., vol. 24, no. 1, pp. 11.8-119, March 24, 1913.

Maynard, 'T. Poole.

781. Pigeon slates of Tennessee: Stone, vol. 34, no. 2, pp. 82-83, February, 1913.

782. The green slates of Georgia: Stone, vol. 34 , no. 4, pp. 198-200, 4 figs., April, 1913.

783. White rock phosphates of Decatur County, Tenn.: Tennessee State Geol. Survey, Resources of Tennessee, vol. 3, no. 3, pp. 161-169, 2 figs., July, 1.913.

.Systematic paleontology of the Lower Deronian deposits of Maryland; Pelecypoda, Gastropoda, Cephalopoda, Trilobita. See Ohern and Maynard, no. 858.

Systematic paleontology of the Lower Devonian deposits of Maryland; Brachiopoda. See schuchert and Maynard, no. 1028.

The Lower Devonian deposits of Maryland. See Schuchert and others, no. 1029.

Local sections of the Lower Devonian [Maryland]. See Swartz and others, no. 1139. 
Mehl, Maurice G.

784. Angistorhinus, a new genus of Phytosauria from the Trias of Wyoming: Jour. Geology, vol. 21, no. 2, pp. 186-191, 1. fig., February-March, 1913.

Permo-Carboniferous vertebrates from New Mexico. See Case, Williston, and Mehl, no. 185.

Meinzer, O. E., and Kelton, F. C.

785. Geology and water resources of Sulphur Spring Valley, Arizona: U. S. Geol. Survey, Water-Supply Paper 320, pp. 9-213, 15 pls., 163 figs., 191.3.

Mercanton, P. L.

786. Les variations périodiques des glaciers, XVIII $^{\mathrm{mo}}$ rappcrt, 1912 ; terres polaires, Grönland: Zeitschr. Gletscherkunde, Bd. 8, H. 1., pp. 60-62, November, 1.913.

Merriam, C. Hart.

787. The remarkable extinct fauna of Southern California revealed in the asphailt deposits near Los Angeles (abstract) : Science, new ser., vol. 38, p. 314, Angust 29, 1913.

Merriam, John C.

788. Tapir remains from late Cenozoic beds of the Pacific coast region: California, Univ., Dept. Geology, Bull., vol. 7, no. 9, pp. 169-175, 2 figs., January 8, 1913.

789. The skull and dentition of a camel from the Pleistocene of Rancho La Brea: California, Univ., Dept. Geology, Bull., vol. 7, no. 14, pp. 305-323, 13 figs., May 24, 1913.

790. A peculiar horn or antler from the Mohave Miocene of California: California, Univ., Dept. Geology, Bull., vol. 7, no. 16, pp. 335-339, 4 figs., September 19, 1913.

791. Notes on the canid genus Tephrocyon: California, Univ., Dept. Geology, Bull., vol. 7, no. 18, pp. 359-372, 16 figs., September 23, 1913.

792. Vertebrate fauna of the Orindan and Siestan beds in middle California : California, Univ., Dept: Geology, Bull., vol. 7, no. 19, pp. 373-385, 9 figs., September 24, 1913.

793. Preliminary report on the horses of Rancho La Brea: California, Univ.; Dept. Geology, Bull., vol. 7, no. 21, pp. 397-41.8, 14 figs., December 16, 1913.

794. New anchitheriine horses from the Tertiary of the Great Basin area : California, Univ., Dept. Geology, Bull., vol. 7 , no. 22, pp. 419-4.34, 5 figs., December 16, 1913.

795. New protohippine horses from Tertiary beds on the western border of the Mohave Desert: California, Lniv., Dept. Geology, Bull., vol. 7, no. 23, pp. 435-441, 4 figs., December 22, 1913.

See also Martin, no. 749 .

Merriam, John C., and Pack, Robert W.

796. Suggested paleontologic correlation between continental Miocene deposits of the Mohave region and marine Tertiary beds of San Joaquin Valley, California (abstract): Geol. Soc. America, Bull., vol. 24, no. 1, p. 128, March 24, 1913. 
Merrill, George P.

797. Dana, the geologist: Geol. Soc. America, Bull., vol. 24, no. 1, pp. 64-68, March 24, 1913.

798. A newly found meteorite from near Cullison, Pratt County, Kansas: U. S. Nat. Mus., Proc., vol. 44, pp. 325-330, 2 pls., April 12, 1913.

799. On the minor constituents of meteorites: Am. Jour. Sci., 4th ser., rol. 35, pp. 509-525, May, 1913.

800. The "fossil forest" of Arizona : Am. Mus. Jour., rol. 13, no. 7 , pp. 311316, 8 figs., Norember, 1913.

Merritt, John Wesley.

801. Structural geology of the Hanover district, New Hampshire (abstract) : Geol. Soc. America, Bull., vol. 24, no. 4, pp. 672-674, 1 pl., 2 figs., December 23, 1913.

Merritt, W. H. See Emmons, no. 355.

Mertie, J. B., jr.

802. Igneous rocks [of the Circle quadrangle, Alaska]: U. S. Geol. Survey, Bull. 538, pp. 36-4S, 2 pls., 1013.

803. Igneous rocks of the Raton Mesa region [New Mexico] (abstract) : Washiugton Acad. Sci., Jour., vol..3, no. 10, p. 302, May 19, 1913.

Merwin, H. E.

804. The simultaneous crystallization of calcite and certain sulphides of iron, copper, and zinc (abstract) : Washington Acad. Sci., Jour., vol. 3, no. 20; p. 504, December 4, 1913.

805. Media of high refraction and some standard media of lower refraction for the determination of refractive indices with the microscope (abstract) :- Geol. Soc. America, Bull., vol. 24 , no: 4 , p. 685 , December 23, 1913.

The sulphides of zinc, cadmium, and mercury; their crystalline forms and genetic conditions; microscopic study (abstract). See Allen and Crenshaw, no. 14.

Two varieties of calciovolborthite (?) from eastern Utah. See Hillebrand and Merwin, no. 504.

Calcium vanadates from Peru, Colorado, and Utah. See Hillebrand, Wright, and Merwin, no. 505.

\section{Mexico, Instituto Geologico.}

806. Memoria de la Comisión del Instituto Geológico de México que exploró la región norte de la Baja California: Mexico, Inst. Geol., Parerg., t. 4, nos. 2-10, pp. $87-534,112$ pls. (incl. maps), 1913.

An account of a survey of the northern part of the peninsula of Lower California, Mexico.

Meyer, Oskar Erich.

807. Die Devonischen Brachiopoden von Ellesmereland: Second Norwegian Arctic Expedition in the "Fram" 1898-1902, Rept., (published by Videnskabs-Selskabet i Kristiania), no. 29, 43 pp., 8 pls., 1913.

Middleton, Jefferson.

808. Clay-working industries; fuller's earth: U. S. Geol. Survey, Mineral Resources, 1912, pt. 2, pp. 525-607, 1017-1022, 1913.

Miller, Arthur M.

809. Ice caves: Science, new ser., vol. 37, pp. 980-981, June 27, 1913. 
Miller, Benjamin I.

810. The graphite industry of Pennsylvania: Min. and Wng. World, rol. 38, . pp. 625-628, 4 figs., March 29, 1913.

811. Tertiary coal fields of the Rio Grande: Coal Age, vol. 4. no. 8 , pp. $260-$ 263, 9 figs., August 23, 1913.

Miller, Loye Holmes.

812. Contributions to avian paleontology from the liacific const of North America (abstract) : Geol. Soc. America, Bull. vol. 24, no. 1, p. 132, March 24, 1913.

Miller, Willet $G$.

813. The principles of classification of the pre-Cambrian rocks, and the extent to which it is possible to establish a chronological classificition: Intern. Geol. Cong., XI, Stockholm 1910, Compt. rend., pp. 673-682, 2 figs. (maps), 1912.

814. The Sudbury-Cobalt-Porcupine region; prefice: Iutern. Geol. Cong., Twelfth, Guide Book no. 7 (issued by the Ontario Bur. Mines), pp. 5-7, 1 geol. map; 1 fig. (map), 1913.

815. The Cobalt area [Ontario]: Intern. Geol. Cong., Twelfth, Guide Book no. 7 (issued by the Ontario Bur. Mines); pp. 51-108, 10 pls., 9 figs., 1913.

816. Temagami [Ontario]: Intern. Geol. Cong., Twelfth, Guide Book no. 7 (issued by the Ontario Bur. Mines), pp. 139-148, 1. pl., 2 figs., 1913.

817. The cobalt-nickel arsenides and silver deposits of Temiskaming (Cobalt and adjacent areas) : Ontario, Bureau of Mines, Rept., vol. 19, pt. 2, 279 pp., 116 figs. in text (including maps and sections), 4 maps (in separate envelope), 1913.

818. Cobalt and adjacent areas [Ontario] : Canadian Min. Jour., vol. 34, pp. 87-90, 3 figs, February 1, 1913.

Gives notes on the geology and structural features of the Cobalt area, Ontario.

See also Lindgren, no. 695.

Miller, Willet G., and Knight, Cyril W.

819. Sudbury, Cobalt, and Porcupine geology [Ontario] : Wng. and Min. Jour., vol. 95, no. 23, pp. 1129-1133, 4 figs. (incl. map). June $7,1913$.

Miller, William J.

820. Early Paleozoic physiography of the southern Adirondacks: New York State Mus., Bull. 164, pp. 80-94, 1913; (abstract) Geol. Soc. America, Bull., vol. 24, no. 4, p. 701., December $23,1913$.

821. The garnet deposits of Warren County, New: York: New York State Mus., Bull. 164, pp. 95-102, 1 fig., 1913.

822. Variations of certain Adirondack basic intrusives: Jour. Geology, vol. 21, no. 2, pp. 160-180, 3 figs., February-Narch, 1913.

Milton, Maxwell C.

823. The Oro Blanco district of Arizona : Eng. and Min. Jour., vol. 96, pp. 1005-1007, 4 figs., November 29, 1913.

Minot, Charles S.

824. A tribute to Joseph Leidy: Science, new ser., vol. 37, pp. 809-814, May $30,1913$. 
Miranda y Marron, Manuel.

825. El temblor del 7 de Junio de 1911: Soc. Cient. "Antonio Alzate," Mem. y Rev., t. 32, nos. 1-3, pp. 27-66, 5 pls., February, 1912.

- Describes the earthquake in Mexico of June 7 , i.911, and discusses its cause and other phenomena.

Miser, Hugh D.

826. Developed deposits of fuller's earth in Arkansas: U. S. Geol. Survey, Bull. 530, pp. 207-220, 1 pl. (map), 3 figs., 1913.

Moffit, Fred $\mathrm{H}$.

827. Geology of the Nome and Grand Central quadrangles, Alaska: U. S. Geol. Survey, Bull. 533, 140 pp., 12 pls., 13 figs., 1913.

828. Mining in .Chitina Valley [Alaska]: U. S. Geol. Survey, Bull. 542, pp. 81-85, 1913.

Gives notes on the geology and the occurrence. and character of copper and gold ores.

Monckton, Geoffrey F.

829. Geological notes on a human skeleton found in silt at Savona, British Columbia: Geol. Mag., dec. 5, vol. 10, pp. 364-370, 1 fig., August, 1913.

Moodie, Roy L.

830. Vertebrate footprints in the lower Permian of Kansas: Am. Jour. Sci., 4th ser., vol. 35, pp. 31-33, 1. fig., January, 1913.

831. The Pennsylvanic Amphibia of the Mazon Creek, Illinois, shales: Kans., Univ., Sci. Bull., vol. 6, no. 2, pp. 323-359, 14 pls., January, 1913.

832. Some recent advances in vertebrate paleontology: Am. Naturalist, vol. 47, pp. 183-192, 248-256, March and April, 1913.

Moon, F. W.

833. Field and office methods in the preparation of geologic reports (discussion ) : Econ. Geology, vol. 8, no. 8, pp 795-797, 2 figs, December, 191.3 .

Moore, Charles J.

834. The London mine, Mosquito mining district, Park County, Colo.: Am. Inst. Min. Eng., Bull. no. 75, pp. 415-427, 4 figs., March, 1913; Min. and Eng. World, vol. 38, pp. 817-818, 2 figs., April 26, 1913.

Gives an account of the local geologic structure and the character, occurrence, and relations of the ore deposits producing chiefly gold and lead.

Moore, Richard. B., and Kithil, Karl L.

835. A preliminary report on uranium, radium, and vanadium: U. S. Bur.

Mines, Bull. 70, 101 pp., 4 pls., 2 figs., 1913.

Moses, A. J.

836. A scheme for utilizing the polarizing microscope in the determination of minerals of nonmetallic luster: School of Mines Quart., vol. 34, no. 4, pp. 305-334, July, 1913.

Mosier, Henry.

837. Field and office methods in the preparation of geologic reports; tables showing apparent dip of structure planes, in any rertical section: Econ. Geology, vol. 8, no. 5, pp. 492-495, 1 fig., 1913. 
Munn, M. J.

838. The Menifee gas field and the Ragland oil field; Kentucky: U. S. Geol. Survey, Bull. 531, pp. 9-26, 4 pls. (maps and sections), 1913.

Murdoch, Joseph.

The sulphide ores of copper; some results of microscopic study. See Graton and Murdoch, no. 437.

Nathorst, A. G.

839. Sur la valeur des flores fossiles des régions arctiques comme preuve des climats géologiques: Intern. Geol. Cong., XXY, Stockholm, 1910, Compt. rend., pp. 743-756, 4 figs. (maps), 1912.

Discusses the value of fossil plants of the Arctic regions in ustab. lishing geologic cllmates.

Nattress, Thomas.

840. Additional notes on the geology of the Detroit River area: Michigan Acad. Sci., 14th Rept., pp. 109-113, 3 pls., 1912.

Neiswender, C. B.

841. Frost crystals formed underground: Eng. and Min. Jour., vol. 96, pp, 492-493, 1 fig., September 13, 1913.

Nelson, Wilbur A.

842. The Tennessee coal field south of the 'Tennessee Central Railrond: Tennessee State Geol. Survey, Resources of Tennessee, vol. 3, no. 1, pp. 26-49, January, 1913. [Also published in Bulletin 2-B.]

843. Mineral products along the Tennessee Central Railroad: 'lemnessee State Geol. Survey, Resources of Tennessee, vol. 3, no. 3, pp. 137-160, 3 figs., July, 1913.

Newland, D. H.

844. The mining and quarry industry of New York state; report of operations and production during 1912: New York State Mus., Bull, 166, 114 pp., 1913.

845. The microstructure of titaniferous magnetites (discussion): Icon. Geology, vol. 8, no. 6, pp. 610-61.3, September, 1913.

Nichols, Ralph.

846. Lead-silver mines of Gilmore, Lemhi County, Idaho: Am. Inst. Min. Eng., Bull. no. 83, pp. 2625-2627, 1 fig., November, 1913.

Nicholson, H. H.

847. Gold deposits and their associated minerals: Min. Sci., vol. 68, pp. 9699. August, 1913.

Nickles, John M.

848. Bibliography of North American geology for 1912, with subject index: U. S. Geol. Survey, Bull. 545, 192 pp., 1913.

Niermeyer, J. F.

849. Kraters in sedimentair gesteente in Arizona en Nieuw-Nexico: Nerlerlandsch Natuur- en Geneeskundig Congres, XIV, Delft, 1913, Handelingen, 6 pp., 1913.

Describes craterlike depressions in Arizona and New Mexico, par* ticularly Meteor Crater, Canyon Diablo, Arizona.

Niggli, Paul.

The general principles underlying metamorphic processes. See John. ston and Niggli, no. 566. 
Nixon, Harmon A., and Tight, Dexter J.

850. Drainage changes in the Moot's Run area, Licking County, Ohio: Denison Univ., Sci. Lab., Bull., yol. 17, pp.219-230, 1 fig., March, 1913 .

North, H. B.

851. Pseudomorphs of limonite after marcasite: Am. Jour. Sci., 4th ser., vol. 35, pp. 270-272, 4 figs., March, 1913.

Norton, Henry $\mathrm{B}$.

852. The drifts and other problems. 163 pp., 8 figs. Minneapolis, Swinburne \& Company, 1913.

Notman, Arthur.

853. Geology of the Bisbee, Arizona, ore deposits: Min. and Eng. World, vol. 38, pp. 567-570, 3 figs., March 22, 1913; Eng. and Min. Jour., vol. 95, no. 11, pp. 557-559, 2 figs., March 15, 1913 .

O'Connell, M.

854. Distribution and occurrence of the eurypterids: Geol. Soc. America, Bull., vol. 24, no. 3, pp. 499-515, September, 1913.

O'Donnell, Gretehen.

855. Bibliography of Washington geology and geography: Washington Geol. Survey, Bull. no. 12, 63 pp., 1913.

Oherm, D. W.

856. Field and office methods in the preparation of geological reports; some suggestions as to field methods: Econ. Geology, vol. S, no. 4, pp. 376-381, 1913.

857. Systematic paleontology of the Lower Devonian deposits of Maryland: Crinoidea, Vermes: Maryland Geol. Survey, Lower Devonian, pp. 249-259, 5 pls. (in plates volume), 1913.

Ohern, D. W., and Maynard, T. P.

858. Systematic paleontology of the Lower Devonian deposits of Maryland; Pelecypoda, Gastropoda, Cephalopoda, Trilobita: Maryland Geol. Survey, Lower Devonian, pp. 450-512, 20 pls. (in plates volume), 1913.

Ontario, Bureau of IMines.

Twenty-second annual report of the Bureau of Mines, 1913. See Gibson, no. 400 .

Ordóñez, Ezequịel.

- 859. Los temblores recientes de Guadalajara : Soc. Cient. "Antonio Alzate," Mem. y Rev., 't. 32, nos. 4-6, pp. 267-272, August, 1912. Describes recent earthquakes in Guadalajara, Mexico.

860. The Magistral district, Jalisco, Mexico: Eng. and Min. Jour., vol. 96, pp. 491-49.2, September 13, 1913.

Includes notes on the geology and occurrence of copper ores.

Ortmann, A. E.

861. The geological origin of the fresh-water fauna of Pennsylvania: Pennsylvania Topog. and Geol. Survey, Rept. 1910-1912, pp. 135-149, 1912.

Includes an account of drainage changes. 
Osborn, Henry Fairfield.

862. Tyrannosaurus, restoration and model of the skeleton: Am. Mus. Nat, Hist., Bull., vol. 32, pp. 91-92, 3 pls., 1913.

863. Eomoropus, an American Eocene chalicothere: Am. Mus. Nat. Hist., Bull., vol. 32, pp. 261-274, 11 figs., 1913.

864. Lower Eocene titanotheres, genera Lambdotherium, Eotitanops: Am, Mus. Nat. Hist., Bull., vol. 32, pp. 407-415, 9 figs., 1913.

865. The skull of Bathyopsis, Wind River uintathere: Am. Mus. Nat. Hist., Bull., vol. 32, pp. 417-420, 3 pls., 4 figs., 191.3 .

866. Phylogeny and ontogeny of the horns of mammals (abstract): New. York Acad. Sci., Annals; vol. 22, p. 341, April 20, 1913.

867. Skull measurements in man and the hoofed mammals (abstract) : New York Acad. Sci., Annals, vol. 22, pp. 341-342, April 20, 1913.

Owen, Luella Agnes.

868. The relation of geological activity to conservation of soil and the waters of flowing streams (abstract): Science, new ser., vol. 37. p. 459, March 21, 1913.

Pack, Robert $W$.

869. Notes on Scutella norrisi and Scutaster andersoni: California, Univ., Dept. Geology, Bull., vol. 7, no. 13, pp. 299-304, 1 pl., June 12, 1913.

Gives original descriptions and additional information bascd on new material from several Miocene localities in southern California,

Suggested paleontologic correlation between continental Miocene deposits of the Mohave region and marine Tertiary beds of San Joaquin Valley, California (abstract). See Merriam and Packr no. 796 .

Paige, Sidney.

870. Pre-Cambrian structure of the northern Black Hills, South Dakota, and its bearing on the origin of the Homestake ore body: Geol. Soc. America, Bull., vol. 24, no. 2, pp. 293-300, 2 figs., June 10, 1913; (discussion by J. D. Irving), vol. 24, no. 4, pp. 704-705, December 23, 1913 ; (abstract), Washington Acad. Sci., Jour., vol. 3, ․o. 6r p. 173, March 19, 1913.

871. Critical criteria on Basin range structure: Science, new ser., vol. 37, pp. 710-711, May 9, 1913.

872. The bearing of progressive increalse of viscosity during intrusion on the form of laccoliths: Jour. Geology, vol. 21, no. 6, pp. 541-549, 9 figs., September-October, 1913.

See also Emmons, no. 358.

Paige, Sidney, and Lloyd, E. Russell.

873. Recent literature on economic geology : Econ. Geology, vol. 8, no. 3, pp. 300-307, 1913; vol. 8, no. S, pp. S07-816, December, 1913.

Palache, Charles.

874. Mineralogy and petrography: Am. Year Book, 1912, pp. 610-611, New York, 1913.

Palache, Charles, and Graham,-R. P. D.

875. On the crystallization of willemite: Am. Jour. Sci., 4th ser., vol. 36, pp. 639-644, 4 figs., December, 1913.

Palache, Charles, and Schaller, Waldemar $\mathrm{T}$.

876. Hodglsinsonite, a new mineral from Franklin Furnace, N. J.: Washington Acad. Sci., Jour., vol. 8, no. 19, pp. 474-478, 2 figs., November 19, 1913. 
Palmer, Chase, and Bastin, Edson S.

877. The rôle of certain metallic minerals in precipitating silver and gold: Am. Inst. Min. Eng., Bull. no. 77, pp. 843-\$57, May, 1913.

878. Metallic minerals as precipitants of silver and gold: Econ. Geology, vol. 8, no. 2, pp. 140-170, 1 pl., 1 fig., March, 1913.

Palmer, Leroy A.

879. Tungsten in Boulder County, Colorado: Eng. and Min. Jour., vol. 96, pp. 99-105, 9 figs., July 19, 1913.

Pardee, J. T.

880. Some further discoveries of rock phosphate in Montana: U. S. Geol. Survey, Bull. 530, pp. 285-291, 2 figs. (including map), 1913.

881. Coal in the Tertiary lake beds of southwestern Montana: U. S. Geol. Survey, Bull. 531, pp. 229-244, 1 pl. (map), 1 fig., 1913.

Describes the stratigraphy and the character, composition, and quality of Tertiary coal.

Paredes, Trinidad.

882. Apuntes sobre algunos minerales del Estado de Chihuahua: Soc. Geol. Mexicana, Bol., t. 8, pt. 1, pp. vii, 21-40, 1912.

Gives notes on the geology, occurrence, and origin of the ore deposits of several mineral districts of Chihuahua, Mexico.

Informe relativo á la parte occidental de la región norte de la Baja California. See Engerrand and Paredes, no. 365.

Parker, Edward w.

883. Coal; coke; fuel briquetting: U. S. Geol. Survey, Mineral Resources, 1912, pt. 2, pp. 5-300, 3 figs., 1913.

Parks, William Arthur.

884. [Ordovician fossils from Shamattawa River (Manitoba) and Silurian fossils from Fawn and Severn rivers (Patricia district, Ontario) ] : Ontario, Bureau of Mines, Twenty-second Ann. Rept., vol. 22, pt. 1, pp. 190-196, Toronto, 1913.

885. The building and ornamental stones of the Province of Quebec: Canada, Dept. Mines, Mines Branch, Summ. Rept., 1912, pp. 76-79, 1913.

886. The paleontology of the Guelph, Onondaga, and Hamilton formations in western Ontario: Intern. Geol. Cong., Twelfth, Guide Book no. 4 (issued by the Canada Geol. Survey), pp. 77-123, maps, pls., 1913.

887. The Paleozoic section at Hamilton, Ontario: Intern. Geol. Cong., Twelftb; Guide Book no. 4 (issued by the Canada Geol. Survey), pp. 125-140, 1 map, 1 fig., pls., 1913.

888. Silurian section at the forks of Credit River: Intern. Geol. Cong., Twelfth, Guide Book no. 5 (issued by the Canada Geol. Survey), pp. 5-13, 1 map, 2 pls., 1 fig., 1913.

889. Ordovician section on Credit River neär Streetsville, Ontario: Intern. Geol. Cong., Twelfth, Guide Book no. 5 (issued by the Canada Geol. Survey), pp. 15-21, 3 figs., 1913.

890. Geology of selected areas on Lakes Erie and Huron in the Province of Ontario: Intern. Geol. Cong., Twelfth, Guide Book no. 5 (issued by the Canada Geol. Survey), pp. 37-107, 1 map, pls., figs., 1913. 
Parsons, Arthur L.

891. The Lake of the Woods and other areas: Ontario, Bureau of Mines, Twenty-second Ann. Rept., rol. 22, pt. 1, pp. 210-232, 1.8 figs., 2 sketch maps, Toronto, 1913.

Describes the geology of the region.

892. Cartier to Coldwell (pp. 14-16); Coldwell to Port Arthur (pp. 24-36); Winnipeg to Port Arthur (pp. 370-386): Intern. Geol. Cong., Twelfth, Guide Book no. 8 (issued by the Canada Geol. Survey), maps, figs., 1913.

Parsons, Charles L.

893. Fuller's earth: U. S. Bur. Mines, Bull. 71, 38 pp., 1913.

Peach, B. N.

The relation between the Cambrian faunas of Scotland and North America: British Assoc. Adv. Sci., Rept. 82d meeting, pp. 44S-450, 1913. See no. 836 of the bibliography for 1912, U. S. Geol. Surrey, Bull. 545, p. 77.

Peale, A. C.

894. The laws of nomenclature in paleontology: Science, new ser., vol. 37 , pp. 979-980, June 27, 1913.

Peck, W. R., and Sampson, R. J.

895. The Harlan coal field in Kentucky: Coal Age, vol. 3, no. 21., pp. 796- $\$ 00$, 3 figs., 1 map, May 24, 1913.

Peele, Robert.

896. Definition of "ore": Min. and Met. Soc. America, Bull. no. 64 (vol. 6, no. 9), pp. 256-263, September, 1913.

Peile, A. J.

897. Notes on the geology of the Bermudia Islands: Geol. Mag., dec. 5, vol. 10, pp. 413-414, September, 1913.

Penhallow, D. F.

898. A report on fossil plants from the International Boundary survey for 1902-05, collected by Dr. R. A. Daly: Canada, Dept. Interior, Report of the Chief Astronomer for 1910, vol. 3, pp. $800-\$ 40$, 9 pls., 5 figs., 1913.

Pennsylvania Topographic and Geologic Survey Commission.

899. Report, 1910-1912. 182 pp., 21 pls., 23 figs. Harrisburg, 1912.

Penrose, R. A. F.

900. The superficial alteration of ore deposits [reprinted from Jour. Geoiogy, vol. 2, no. 3, pp. 2SS-317, April-May, 1894]. In Emmons, S. F., Ore deposits, pp. 110-138, published by the American Institute of Mining Engineers, New York, 1913.

901. The Twelfth International Geological Congress: Franklin Inst., Jour., vol. 176, no. 5, pp. 583-586, November, 1913.

Perret, Frank A.

902. The lava fountains of Kilauea: Am. Jour. Sci., 4th ser., vol. 35, pp. 139-148, 7 figs., February, 1913.

903. The floating islands of Halemaumau: Am. Jour. Sci., 4th ser., vol. 35, pp. 273-2\$2, 6 figs., March, 1913.

904. The circulatory system in the Halemaumau lava lake during the summer of 1911: Am. Jour. Sci., 4th ser., vol. 35, pp. 337-349, 6 figs., April, 1913. 
Penrose, R. A. F.-Continued.

905. Subsidence phenomena at Kilauea in the summer of 1911: Am. Jour. Sci., 4th ser., vol. 35, pp. 469-476, 6 figs., May, 1913.

906. Some Kilauein ejectamenta: Am. Jour. Sci., 4th ser., vol. 35, pp. 611618, 7 figs., June, 1913.

907. Some Kilauean formations: Am. Jour. Sci., 4th ser., vol. 36, pp. 151-159, 7 figs, August, 1913.

908. A method of increasing and controlling the period in vertical motion seismographs: Am. Jour. Sci., 4th ser., vol. 36, pp. 297-300, 1 fig., September, 1913.

909. Volcanic research at Kilauea in the summer of 1911 ; with a report by Dr. Albert Brun on the material taken directly from "Old Faithful ": Am. Jour. Sci., 4th ser., vol. 36, pp. 475-488, 5 figs., November, 1913.

910. The ascent of lava: Am. Jour. Sci., 4 th ser., vol. 36 , pp 605-608, 2 figs., December, 1913.

Petrunkevitch, Alexander.

911. A monograph of the terrestrial Paleozoic Arachnida of North America: Connecticut Acad. Arts and Sci., Trans., vol. 18, pp. 1-137, SS figs., 13 pls., 1913.

912. Paleozoic Arachnida-scorpions and spiders (abstract): Geol. Soc. America, Bull., vol. 24, no. 1, p. 106, March 24, 1913.

Phalen, W. C.

913. Kenova, Kentucky, West Virginia, and Ohio, folio (abstract) : Washington Acad. Sci., Jour., vol. 3, no. 17, p. 455, October 19, 1913.

914. The occurrence of potash salts in the bitterns of the eastern United States: U. S. Geol. Survey, Bull. 580, pp. 313-329, 1913.

915. Phosphate rock; potash salts, summary for 1912; salt and bromine; sulphur, pyrite, and sulphuric acid: U. S. Geol. Survey, Mineral Resources, 1912, pt. 2, pp. S55-953, 1913.

916. Bauxite and aluminum: U. S. Geol. Survey, Mineral Resources, 1912, pt. 1, pp. 949-962, 1 fig., 1913.

917. Prospecting for bauxite-aluminum ore: Min. and Sci. Press, vol. 105, pp. 305-307, 4 figs., September 7, 1912.

918. Prospecting for chromium ore: Min. and Sci. Press, vol. 105, pp. 400401, September 28, 1912.

Description of the Ellijay quadrangle, Georgia-North Carolina, Tennessee. See La Forge and Phalen, no. 643.

Phillips, Alexander $\mathrm{H}$.

919. A simple model for illustrating the symmetry of crystals: Am. Jour. Sci., 4th ser., vol. 36, pp. 30-32, 1 fig., July, 1913.

Piers, Harry.

920. The occurrence of opal in granite near New Ross, Lunenburg County, N. S.: Nova Scotian Inst. Sci., Proc. and Trans., vol. 12, pt. '4, pp. 446-449, August 30, 1913.

Pilsbry, Henry A.

Fauna of the Gatun formation, Isthmus of Panama, II. See Brown and Pilsbry, no. 115.

Two collections of Pleistocene fossils from the Isthmus of Panama. See Brown and Pilsbry, no. 116.

Pirsson, L. V. See Cushing, no. 273. 
Pirsson, L. V., and Vaughan, T. Wayland.

921. A deep boring in Bermuda Island: Am. Jour. Sci., 4th ser., vol. 36, pp. 70-71, July, 1913.

Pogue, Joseph E.

922. On a cerusite twin from the Mammoth mine, Pinal County, Arizona: Am. Jour. Sci., 4th ser., vol. 35, pp. 90-92, January, 1913.

The Mount Lyell copper district of Tasmania. See Gilbert and Pogue, no. 405 .

Porter, J.

923. Geological features of the Coast Range [in British Columbia]: The Northern Cordilleran (published by the British Columbia Mountaineering Club), pp. 46-50, 1913.

Postma, G. E.

924. Trachytic perlite from Lone Hill, near San José, California (abstract) : Geol. Soc. America, Bull., vol. 24, no. 1, p. 94, March 24, 1913.

Powers, Sidney.

A new sponge from the New Jersey Cretaceous. See Shimer and Powers, no. 1046.

Pratt, Joseph Hyde.

925. Biennial report of the State geologist, 1911-1912: North Carolina Geol. and Econ. Survey, 118 pp., 1913.

926. New occurrences of monazite in North Carolina: Elisha Mitchell Sci. Soc., Jour., vol. 28, no. 4, pp. 153-156, February, 1913 ; (abstract), Geol. Soc. America, Bull., vol. 24, no. 4, p. 686, December 23, 1913.

927. Geological history of western North Carolina : Elisha Mitchell Sci. Soc., Jour, vol. 29, no. 2, pp. 35-44, October, 1913.

Price, George McCready.

928. The fundamentals of geology and their bearings on the doctrine of a literal creation. 267 pp., 35 figs., 1 map. Mountain View, California, Pacific Press Publishing Association, 1913.

Prindle, L. M.

929. A geologic reconnaissance of the Fairbanks quadrangle, Alaska; with a detailed description of the Fairbanks district by L. M. Prindle and F. J. Katz and an account of lode mining near Fairbanks by Philip S. Smith: U. S. Geol. Survey, Bull. 525, 220 pp., 22 pls., 20 figs., 1913.

930. A geologic reconnaissance of the Circle quadrangle, Alaska: U. S. Geol. Survey, Bull. 538, 82 pp., 13 pls. (incl. maps in pocket), 2 figs. (maps), 1913.

Prindle, L. M., and Katz, F. J.

931. Detailed description of the Fairbanks district: U. S. Geol. Survey, Bull. 525, pp. 59-152, pls. 1, 2, 8, 11 (in pocket), pls. 12-21., text figs. 6-14, 1913.

Prosser, Charles S.

932. The Huron and Oleveland shales of northern Ohio: Jour. Geology, vol. 21 , no. 4, pp. 323-362, 8 figs., 1.913.

933. Lower Devonian; introduction, historical review and bibliography: Maryland Geol. Survey, Lower Devonian, pp. 42-66, 1913.

934. Systematic paleontology of the Middle Devonian deposits of Maryland;

Cœlenterata : Maryland Geol. Survey, Middle and Upper Devonian, pp. 119-122, 1 pl. (in plates volume), 1913.

$38416^{\circ}-$ Bull. $584-14-6$ 
Prosser, Charles S., and Kindle, E. M.

935. Systematic paleontology of the Middle Devonian deposits of Maryland; Brachionoda, Pelecypoda, Gastropoda, Cephalopoda, Trilobita: Maryland Geol. Survey, Middle and Upper Devonian, pp. 124-335, $36 \mathrm{pls}$. (in plates volume), 1913.

Prosser, Charles S., and Swartz, Charles K.

936. The Upper Devonian deposits of Maryland: Maryland Geol. Survey, Middle and Upper Devonian, pp. 339-409, 2 pls., 1913.

Prosser, Charles S., Kindle, Edward M., and Swartz, Charles K.

937. The Middle Devonian deposits of Maryland: Maryland Geol. Survey, Middle and Upper Devonian, pp. 23-114, 1 fig., 2 pls., 1913.

Prutzman, Paul W.

938. Petroleum in southern California: California State Min. Bureau, Bull. 63, 430 pp., pls., figs., and maps, 1913.

Pulsifer, H. B.

939. Development of the Wisconsin zinc field: Min. and Eng. World, vol. 38, pp. 1231-1233, 5 figs., June 14, 1913.

Purdue, A. H.

840. Water supply for cities and towns: Tennessee State Geol. Survey, The Resources of Tennessee, vol. 3, no. 2, pp. 80-83, 1 fig., April, 1913. Includes notes on the geology of Etowah, McMinn County, Tenn.

941. Geology and engineering: Tennessee State Geol. Survey, The Resources of Tennessee, vol. 3, no. 2, pp. 105-109, 3 figs., April, 1913.

942. The gullied lands of west Tennessee: Tennessee State Geol. Survey, Resources of Tennessee, vol. 3, no. 3, pp. 119-136, 8 figs., July, 1913.

943. The minerals of Tennessee, their nature, uses, occurrence, and literature (literature by Elizabeth Cockrill): Tenn. State Geol. Survey, Resources of Tennessee, vol. 3, no. 4, pp. 183-230, October, 1913.

944. Field and office methods in the preparation of geologic reports; note taking: Econ. Geology, vol. 8, no. 7, p. 712, October, 1913.

\section{Ransome, F. L.}

945. Notes on the Bisbee district, the Globe and Miami districts, Ray, and Jerome, Arizona: U. S. Geol. Survey, Bull. 529, pp. 179-187, 192193, 1913.

Discusses the geology and the occurrence and character of the copper ores.

946. The Turquoise copper-mining district, Arizona: U. S. Geol. Survey, Bull. 530, pp. 125-134, 2 figs., 1913.

Describes the general geology and the character, occurrence, and relations of copper deposits.

947. [Protore, term for unenriched pyritic material] : Econ. 'Geology, vol. 8, no. 7, p. 721, October, 1913.

948. Economic geology : Am. Year Book, 1912, pp. 607-610, New York, 1913. Report of the committee on the nomenclature of faults. See Reid and others no. 967 . 
Raymond, Percy E.

949. Some changes in the names of genera of trilobites: Ottawa Naturalist, vol. 26 , no. 11, pp. 137-142, February, 1913.

950. A further note on Cryptolithus versus Trinucleus: Ottawa Naturalist, vol. 27, pp. 26-30, May, 1913.

951. Excursion in eastern Quebec and the maritime provinces; Quebec and vicinity (pp. 25-48) : Intern. Geol. Cong., Twelfth, Guide Book no. 1 (issued by the Canada Geol. Survey), 1913.

952. Ordovician of Montreal and Ottawa: Intern. Geol. Cong., Twelfth, Guide Book no. 3 (issued by the Canada Geol. Survey), pp. 137160, 1913.

953. Notes on Cyclocystoides: Canada Geol. Survey, Victoria Memorial Mus., Bull. no. 1, pp. 23-32, 1 pl., 2 figs., October 23, 1913.

954. Notes on some new and old trilobites in the Victoria Memorial Museum : Canada Geol. Survey, Victoria Memorial Mus., Bull. no. 1, pp. 33-39, 2 pls., October 23, 1913.

955. Description of some new Asaphidæ: Canada Geol. Survey, Victoria Memorial Mus., Bull. no. 1, pp. 41-48, 3 pls., October 23, 1913.

956. 'Two new species of Tetradium: Canada Geol. Survey, Victoria Memorial Mus., Bull. no. 1, pp. 49-50, 2 pls., October 23, 1913.

957. A revision of the species which have been referred to the genus Bathyurus: Canada Geol. Survey, Victoria Memorial Mus., Bull. no. 1, pp. 51-69, 1 pl., October 23, 1913.

958. Correlation of the middle Ordovician formations of Ontario and Quebec (abstract) : Geol. Soc. America, Bull., vol. 24, no. 1, p. 111, March. 24, 1913.

Raymond, Percy E., and Barton, Donald C.

959. A revision of the American species of Ceraurus: Harvard Coll., Mus. Comp. Zoöl., Bull., vol. 54, no. 20, pp. 525-543, 2 pls., 3 figs., November, 1913.

Read, Thomas T.

950. The sulphide ores of copper; some results of microscopic study (discussion ) : Am. Inst. Min. Eng., Bull. no. 82, pp. 2609-2610, October, 1913.

Reed, G. E.

Bibliography of the department of geology of the Johns Hopkins University, 1S83-1913. See Mathews and Reed no. 765.

Reger, David B.

[Report on the history and physiography, geology, and mineral resources of] Marion, Monongalia, and 'Taylor counties [West Virginia]. See Hennen and Reger, no. 479.

Reid, Harry Fielding:

961. Determination of the constants of a seismograph: Seism. Soc. America Bull,, vol. 3, no. 1, pp. 24-33, 1 fig., March, 1913.

962. Varlations of glaciers, XVII : Jour. Geology, vol. 21 , no. 5, pp. 422-426, 1913.

963. Supplément au $X V I I^{m}$ rapport sur les variations périodiques des glaciers; Amérique du Nord, Etats-Unis: Zeitschr. Gletscherkunde, Bd. 7, H. 3, pp. 201-202, July, 1913.

964. Variations of glaciers, XVIII : Jour. Geology, vol. 21, no. 8, pp. 748-753, November-December, 1913. 
Reid, Harry Fielding-Continued.

965. Les variations périodiques des glaciers, XVIII $^{\text {me }}$ rapport, 1912; Amérique du Nord, Etats-Unis: Zeitschr. Gletscherkunde, Bd. 8, H. 1, pp. 57-60, November, 1913.

966. Earthquakes and volcanoes: Am. Year Book; 1912, pp. 611-613, New York, 1913.

See also Johnston and Adams, no. 565, and Goldthwait, no. 415.

Reid, Harry Fielding, and others.

967. Report of the committee [of the Geological Society of America] on the nomenclature of faults: Geol. Soc. America, Bull., vol. 24, no. 2, pp. 163-186, 18 figs., June 6, 1913. [Preliminary edition with the title, Proposed nomenclature of faults, subject to revision, was printed May 1, 1912.]

Reinecke, L.

968. Bibliography of Canadian geology for the years 1908 to 1911 (inclusive) : Roy. Soc. Canada, Proc. and Trans., $3 d$ ser., vol. 6 , sect. 4 , pp. 139-226, 1912.

Rice, E. R.

969. Graphics applied to fault problems: Eng. and Min. Jour., vol. 95, no. 12, pp. 609-612, 5 . figs., March 22, 1913.

Rice, William North.

970. Dana, the man: Geol. Soc. America, Bull., vol. 24, no. 1, pp. 56-60, March 24, 1913.

See also Huntington, no. 541.

Richards, Ralph W.

971. Methods of field work in the phosphate districts of Idaho, Montana, Wyoming, and Utah (discussion) : Econ. Geology, vol. 8, no. 2, pp. 181-188, March, 1.913.

972. Niter near Melrose, Montana (abstract) : Washington Acad. Sci., Jour., vol. 3 , no. 10 , p. 301 , May $19,1913$.

A geologic reconnaissance in southeastern Idaho. See Schultz and Richards, no. 1030.

Richards, R. W., and Mansfield, G. R.

973. Structural features of a portion of southeast Idaho (abstract) : Geol. Soc. America, Bull., vol. 24, no. 4, p. 675, December 23, 1913.

974. Bannock thrust-a major fault in southeast Idaho (abstract and discussion by Eliot Blackwelder) : Geol. Soc. America, Bull., vol, 24, no. 4, pp. 675-676, December 23, 1913.

Richards, W. B.

975. Geology of the Panther Creek Valley, Pennsylvania: Coal Age, vol. 3, no. 19, pp. 722-727, 5 figs. (incl. maps and sections), May 10, 1913.

Richardson, Charles H.

976. Economic geology. 320 pp., 133 figs. New York, McGraw-Hill Book Company, 1913.

Richarāson, G. B.

977. The Paleozoic section in northern Utah: Am. Jour. Sci., 4th ser., vol. 36, pp. 406-416, October, 1913.

Portland cement materials and industry; El Paso, Texas. See Eckel, no. 342.

The Harmony, Colob, and Kanab coal fields, southern Utah: Utah, State Mine Inspector, 8th Bienn. Rept., 1911-1912, pp. 141-170, 1 pl. (map), 1913.

A reprint of the paper in U. S. Geol. Survey, Bull. 341, pp. 379-400, 1909. 
Rickard, Forbes.

978. Pitchblende from Quartz Hill, Gilpin County, Colorado: Min. and Sci. Press, vol. 106, pp. 851-856, \& figs., June 7, 1913.

Includes notes on the geology and ore deposits of the district.

Rickard, T. A.

979. Water in veins: Min. and Sci. Press, vol. 107, pp. 693-694, November 1, 1913.

Ridgway, John L.

980. Field and office methods in the preparation of geological reports (discussion); illustrations: Econ. Geology, vol. 8, no. 3, pp. 279-289, 1913.

Ries, Heinrich.

981. Fire-clay deposits of Canada: Am. Inst. Min. Eng., Bull. no. 75, pp. 429-442, 3 figs., March, 1913.

982. Recent changes in the Asulkan Glacier [British Columbia] (abstract) : Geol. Soc. America, Bull., vol. 24, no. 4, p. 696, December 23, 1913.

Rietz, Henry Lewis.

The determination of the relative volumes of the components of rocks by mensuration methods. See Lincoln and Rietz, no. 691.

Riter, George W.

982. Asphalt and rare hydrocarbons: Utah, State Mine Inspector, 8th Bienn. Rept., 1911-1912, pp. 126-1.29, 191.3.

Gives notes on the occurrence of hydrocarbons in Utah.

Ritter, Etienne A.

984. The Rico mining district, Colorado: Min. and Eng. World, vol. 38, pp. 895-898, 2 figs., May 10, 1.913.

Rivers, J. J.

985. A new species of Bathytoma from the upper Pleistocene of San Pedro, Cal.: Southern California Acad. Sci., Bull., vol. 12, no. 2, p. 29, 1. pl., July, 1913.

Robertson, William Fleet.

986. Report of the [British Columbia] Bureau of Mines. British Columbia, Minister of Mines, Annual Report, for 1912. 349 pp., pls. and maps. Victoria, B. C., 191.3.

Robinson, Henry Hollister.

987. The San Franciscan volcanic field, Arizona: U. S. Geol. Survey, Prof. Paper 76, 213 pp., 14 pls., 36 figs., 1913.

Describes the physlographic features, the stratigraphy, the geology of the volcanoes (extinct) and lava fields, the geologic history of the region, and the petrography of the rocks of the San Francisco area in north cential Arizona.

Rogers, A. P.

988. The Byron oil field of Wyoming: Eng. and Min. Jour., vol. 96, p. 869, November 8, 1913.

Rogers, Austin F.

989. Delafossite, a cuprous metaferrite from Bisbee, Arizona : Am. Jour. Sci., 4th ser., vol. 35, pp. 290-294, 2 figs., March, 1913.

990. Observations on the feldspars: Jour. Geology, vol. 21, no. 3, pp. 202-207, 7 figs., 1913. 
Rogers, Austin F.-Continued.

991. The nomenclature of minerals: Am. Philos. Soc., Proc., vol. 52, pp. 606615, November-December, 1913.

992. Upward secondary sulphide enrichment and chalcocite formation at

Butte, Montana: Econ. Geology, vol. S, no. 8, pp. 781-794, 6 figs., December, 1913.

993. Validity of the law of rational indices of crystal faces (abstract) : Geol. Soc. America, Bull., vol. 24, no. 1, p. 93, March 24, 1.913.

994. Gypsum and anhydrite from the Ludwig mine, Lyon Courity, Nevada (abstract) : Geol. Soc. America, Bull., vol. 24, no. 1., p. 94, March 24, 1913.

Dahllit (Podolit) von Tonopah, Nevada; Voelckerit, ein neues basische Calciumphosphat; Bemerkungen iiber die chemische Zusammensetzung von Apatit und Phosphorit: Zeitschr. Kryst, Min. Bd. 52, H. 2, pp. 209-21.7, 1 fig., 1913.

Translated from paper in the American Journal of Science, 4th ser., vol. 33, pp. $475-482$. See no. 925 of the Bibliography for 1912 , U. S. Geol. Survey, Bull. 545 , p. 84.

Rogers, G. Sherburne.

995. The Little Sheep Mountain coal field, Dawson, Custer, and Rosebud counties, Montana: U. S. Geol. Survey, Bull. 531, pp. 159-227, 3 pls. (maps and sections), 3 figs., 1913.

996. A study in the petrology of sedimentary rocks: Jour. Geology, vol. 21, no. 8, pp. 714-727, 4 figs., November-December, 1913.

Discusses the petrology of sedimentary rocks and its use in stratigraphic determinations and describes particularly the petrologic character of the Lebo shale member of the Fort Union formation, its mode of formation and the character and source of the material.

997. Overthrust fault in nearly flat strata: Jour. Geology, vol. 21, no. 6, pp. 534-536, 2 figs., September-October, 1913.

Roorbach, G. B.

998. The fault-block topography of the Mohawk Valley: Geog. Soc. Philadelphia, Bull., vol. 11, no. 3, pp. 51-66, 9 figs., July, 1913.

Rose, L.

999. Zur Frage der Entstehung der Erzlagerstätten von Leadville (Kolorado) : Glückauf, Jg. 49, Nr. 23, pp. 885-888, 1913.

Discusses the genesis of the ore deposits at Leadville, Colo.

Rowe, R. B.

The Lower Devonian deposits of Maryland. See Schuchert and others, no. 1029.

Local sections of the Lower Devonian [Maryland]. See Swartz and others, no. 1139.

Ruckman, John $\mathrm{H}$.

1000. Evidence indicating an unconformity at the base of the Tamiosoma zone in the Coalinga oil field, California (abstract, with discussion by J. A. Taff) : Geol. Soc. America, Bull., vol. 24, no. 1, p. 132, March 24, 1913.

Ruthven, A. G.

Progress of the geological and biological survey. of Michigan. See Allen and Ruthven, no. 16. 
Sales, Reno H.

1001. Ore deposits at Butte, Mont.: Am. Inst. Min. Eng., Bull. no. 80, pp. 1523-1616, 6 pls., 7 figs., August, 1913; (in part), Eng. and Min. Jour., vol. 96, pp. 439-440, September 6, 1913; Eng. and Min. Jour., vol. 96, pp. 587-589, September 27, 1913 ; Min. and Sci. Press, vol. 107, pp. 453-459, September 20, 1913.

Describes the geologic structure of the district and the vein systems and discusses the genesis of the copper ores.

Salisbury, Rollin D., and Trowbridge, Arthur C.

1002. Laboratory exercises in structural and historical geology; a laboratory manual based on folios of the United States Geological Survey, for use with classes in strućtural and historical geology. 76 pp. New York, Henry Holt and Company, 1913.

Sampson, F. A.

1003. The New Madrid and other enrthquakes of Missouri: Seism. Soc. America, Bull., vol. 3, no. 2, pp. 57-71, June 13, 1913.

Sampson, R. J.

The Harlan coal field in Kentucky. See Peck and Sampson, no. 895.

Sanford, Samuel.

1004. The underground-water resources of the Constal Plain province of Virginia: Virginia Geol. Survey, Bull. no. 5, 361 pp., 1 pl. (map), $S$ figs., 11 tables, 1913.

Geology and ground waters of Florida. See Matson and Sanford, no. 768 .

Sapper, Karl.

1005. Das Erdbeben von Sarchi. (Kostarika) am 6. Juni 1912: Petermanns Mitt., Jg. 58, pp. 340-341, 1. pl., December, 1912.

Describes the earthquake of Sarchi, Costa Rica.

1006. Die mittelamerikanischen Vulkane: Petermanns Mitt., Ergiinzungshef't

Nr. 178, 173 pp., 5 figs., 1 pl. (maps), 1913.

Describes the distribution, condition of activity, and other features of the volcanoes of Central America.

Savage, T. D.

1007. Alexandrian series in Missouri and Illinois: Geol. Soc. America, Bull., vol. 24, no. 2, pp. 351-376, June 27, 1913; (abstract), vol. 24, no. 1, pp. 111-112, March 24, 1913.

1008. Stratigraphy and paleontology of the Alexandrian series in Illinois and Missouri: Illinois State Geol. Survey, Extract from Bull. 23, 124 pp., 7 pls., 1913.

1009. Some interesting new species of arthropods from Devonian strata of Illinois: Am. Jour. Sci., 4th ser., vol. 35, pp. 149-152, 5 figs., February, 1913.

Description of the Tallula and Springfield quadrangles, Illinois. See Shaw and Savage, no. 1042.

Sayles, Robert W.

1010. The history of Lost River [New Hampshire] : Science, new ser., vol. 37, pp. 611-613, April 18, 1913.

1.011. Earthquakes and rainfall: Seism. Soc. America, Bull., vol. 3, no. 2, pp. 51-56, 1 pl., June, 1913. 
Schaller, Waldemar $\mathrm{T}$.

1012. Immense bloedite crystals: Washington Acad. Sci., Jour., vol. 3, no. 3, pp. 75-76, February 4, 1913.

1013. The calculation of mineral formulas: Washington Acad. Sci., Jour., vol. 3, no. 4, pp. 97-98, February 19, 1913.

1014. A study of the tourmaline group (abstract): Washington Acad. Sci., Jour., vol. 3, no. 5, p. 151, March 4, 1913.

1015. Die Krystallform des Natronamblygonits: Zeitschr. Krystallographie, Bd. 51, H. 3, pp. 246-247, 1912. The crystallography of natramblygonite (abstract): Washington Acad. Sci., Jour., vol. 3, no. 5, p. 152, March 4, 1913.

1016. Über "feste Lösungen" in Turmalin: Zeitschr. Kryst. Min., Bd. 53, H. 2, p. 181, 1913.

A note in regard to solld solution in tourmaline.

1017. The refractive indices of strengite: Washington Acad. Sci., Jour., vol. 3, no. 9, pp. 249-250, May 4, 1913.

Hodgkinsonite, a new mineral from Franklin Furnace, New Jersey. See Palache and Schaller, no. 876.

Custerite; a new contact metamorphic mineral. See Umpleby, Schaller, and Larsen, no. 1197.

Schmid, Hugh S. de.

1018. Continued examination of the phosphate and feldspar deposits of Ontario and Quebec: Canada, Dept. Mines, Mines Branch, Summ. Rept. 1912, pp. 86-88, 1913.

Schneider, Hyrum.

1019. Physiography of Golden [Colorado] and vicinity and its relation to the geologic structure: Colorado School of Mines, Quart., vol. 8, no. 3, pp. 1-12, 5 figs., 1 topog. map, October, 1913.

Schofield, S. J.

1020. The Cordillera (pp. 18-21) ; Elko to Kootenay Lake, British Columbia (pp. 46-61): Intern. Geol. Cong., Twelfth, Guide Book no. 9 (issued by the Canada Geol. Survey), maps, pls., 1913.

Schrader, Frank C.

1021. Notes on the Antelope district, Nevada: U. S. Geol. Survey, Bul1. 530, pp. 87-98, 1 pl. (map), 2 figs., 1913.

Describes the geologic features and the occurrence and character of gold and silver deposits.

1022. Alunite in Patagonia, Arizona, and Bovard, Nevada: Econ. Geology, vol. 8, no. 8, pp. 752-767, December, 1913.

Schuchert, Charles.

1023. Lower Devonian; introduction, paleogeography of the Devonian: Maryland Geol. Survey, Lower Devonian, pp. 33-41, 9 pls., 1913.

1024. Systematic paleontology of the Lower Devonian deposits of Maryland; Cystoidea: Maryland Geol. Survey, Lower Devonian, pp. 227-248, 12 figs., 6 pls. (in plates volume), 1913.

1025. The Cataract; a new formation at the base of the Siluric in Ontario and New York (abstract): Geol. Soc. America, Bull., vol. 24, no. 1, p. 107, March 24, 1913.

1026. Field and office methods in the preparation of geologic reports; fossils for stratigraphic purposes: Econ. Geology, vol. 8, no. 6, pp. 588597, September, 1913. 
Schuchert, Charles-Continued.

1027. The delimitation of the geologic periods illustrated by the paleogeography of North America: Intern. Geol. Cong., Twelfth, Canada, 34 pp., 1 pl., 1913 (advance copy).

Local sections of the Lower Devonian [Maryland]. See Swartz and others, - no. 1139.

Schuchert, Charles, and Maynard, T. P.

1028. Systematic paleontology of the Lower Devonian deposits of Maryland; Brachiopoda: Maryland Geol. Survey, Lower Devonian, pp. 290449, $22 \mathrm{pls}$ (in plates volume), 1913.

Schuchert, Charles, and others.

1029. The Lower Devonian deposits of Maryland: Maryland Geol. Survey, Lower-Devonian, pp. 67-96, 3 pls., 1913.

Schultz, A. R., and Richards, R. W.

1030. A geologic reconnaissance in southeastern Idaho: U. S. Geol. Survey, Bull. 530, pp. 267-2\$4, 1 pl. (map), 4 figs., 191.3.

Gives a general account of the geology and of the occurrence of phosphates and other mineral resources.

Schwarz, -

1031. Le charbon au Mexique: Soc. Cient. "Antonio Alzate," Mem. y Rev., t 32 , nos. 1-2, Rev. pp. 1.23, 3 figs. (including map), February, 1912.

Describes the coal fields of Mexico, including notes on the geology.

Scott, William Berryman.

1032. A history of land mammals in the western hemisphere. xiv, $693 \mathrm{pp}$., pls., figs. New York, The Macmillan Company, 1913.

1033. Restoration of Tertiary mammals (abstract): Geol. Soc. America, Bull., vol. 24, no. 1, pp. 105-1.06, March 24, 1913.

Sellards, E. H.

1034. Classification of the soils of Florida: Florida, Dept. Agr., 1.2th Bienn. Rept., pp. 249-300, 1913.

1035. Administrative report: Florida State Geol. Survey, Fifth Ann. Rept., pp. 7-22, 1913.

1036. Origin of the hard rock phosphates of Florida: Florida State Geol. Survey, Fifth Ann. Rept., pp. 23-80, 9 pls., 1 map, 1.913.

1037. Origin of the hard rock phosphate deposits of Florida (abstract): Geol. Soc. America, Bull., vol. 24, no. 4, pp. 716-71.7, December 23, 1913.

Sellards, E. H., and Gunter, Herman.

1038. Artesian water supply of eastern and southern Florida: Florida State Geol. Survey, Fifth Ann. Rept., pp. 103-290, 17 figs., 5 pls., 1. map (in pocket), 1.913.

Shannon, Earl V.

1039. Secondary enrichment in the Caledonia mine, Cour d'Alene district, Idaho: Econ. Geology, vol. 8, no. 6, pp. 565-570, September, 1913.

1040. On a supposed new occurrence of plattnerite in the Cœur d'Alene: Am. Jour. Sci., 4th. ser., vol. 36, pp. 427-428, October, 1913.

Shaw, Eugene Wesley.

1041. The mud lumps at the mouths of the Mississippi: U. S. Geol. Survey, Prof. Paper S5-B, 27 pp., 3 pls., 6 figs., December 20, 1.913; (abstract), Washington Acad. Sci., Jour., vol. 3, no. 11, p. 343, June 4, 1913. 
Shaw, E. W., and Savage, T. E.

1042. Description of the Tallula and Springfield quadrangles, Illinois: U. S.

Geol. Survey, Geol. Atlas U. S., Tallula-Springfield folio (no. 188), 12 pp., 4 pls. (maps), 14 figs., 1913.

Shedd, John C.

1043. Radioactivity of the mineral springs of Manitou, Colorado: Colorado

Sci. Soc., Proc., vol. 10, pp. 233-263, \& text figs., June, 1913. Includes an account of the geology of the Manitou region.

Shepherd, E. S.

Water and volcanic activity. See Day and Shepherd, no. 300 .

Water and the magmatic gases. See Day and Shepherd, no. 301.

Shimek, Bohumil.

1044. The significance of Pleistocene mollusks: Science, new ser., vol. 37, pp. 501-509, April 4, 1913.

Shimer, Hervey W.

1045. Spiriferoids of the Lake Minnewanka section, Alberta: Geol. Soc. America, Bull., vol. 24, no. 2, pp. 233-240, June 9, 1913; (abstract), Geol. Soc. America, Bull., vol. 24, no. 1, pp. 112-113, March 24, 1913.

Shimer, Hervey W., and Powers, Sidney.

1046. A new sponge from the New Jersey Cretaceous: U. S. Nat. Mus., Proc., vol. 46, pp. 155-156, 1 pl., December 6, 1913.

Shufeldt, Robert Wilson.

1047. Contributions to avian paleontology; I, The status of extinct Meleagridæ; II, Studies of the fossil birds of the Oregon desert: The Auk, vol. 30, no. 1, pp. 29-39, 1. pl., January, 1913.

Discusses the synonymy of the fossil Meleagridæ and gives notes on fossil birds from Oregon.

1048. New and extinct birds and other species from the Pleistocene of Oregon: Science, new ser., vol. 37, pp. 306-307, February 21, 1913.

1049. Extinct ostrich birds of the United States: Aquila, Bd. 20, pp. 411-422, 5 pls., 1913.

1050. Review of the fossil fauna of the desert region of Oregon, with a description of additional material collected there: Am. Mus. Nat. Hist., Bull., vol. 32, pp. 123-178, 35 pls., 1913.

1051. Further studies of fossil birds with descriptions of new and extinct species: Am. Mus. Nat. Hist., Bull., vol. 32, pp. 285-306, 9 pls., 1913.

1052. Fossil feathers and some heretofore undescribed fossil birds: Jour. Geology, vol. 21, no. 7, pp. 628-652, 12 figs., October-November, 1913.

Siebenthal, C. E.

1053. Lead; zinc; cadmium: U. S. Geol. Survey, Mineral Resources, 1912, pt. 1., pp. 335-416, 1061-1063, 4 figs., 1913.

Singewald, Joseph T.

1054. The microstructure of titaniferous magnetites: Econ. Geology, vol. 8, no. 3, pp. 207-214, 7 pls., 1913; (abstract), Geol. Soc. America, Bull., vol. 24, no. 4, p. 704, December 23, 1913.

1055. Ein Titaneisenerzvorkommen kontaktmetamorpher Entstehung: Zeitschr. prakt. Geologie, Jg. 21, pp. 279-280, 1 fig., June, 1913.

Describes an occurrence of titaniferous iron ore of contact metamorphic origin in the Cebolla district, Colorado.

1056. The relations of ilmenite to magnetite in titaniferous magnetite (abstract) ; Washington Acad. Sci., Jour., vol. 3, no. 7. p. 199, April 4, 1913 . 
Slocom, Arthur Ware.

1057. New trilobites from the Maquoketa beds of Fayette county, Iowa:

Field Mus. Nat. Hist., Pub. 171, Geol. ser., vol. 4, no. 3, pp. 43-83, 6 pls., 1 fig., October, 1913.

Smith, Eugene A.

Portland cement materials and industry; Alabama. See Eckel, no. 342 .

Smith, F. C.

1058. Field and office methods in the preparation of geological reports: Econ.

Geology, vol. S, no. 4, pp. 383-386, 191.3.

Smith, H. D.

A selected list of the more important contributions to the investigation of the origin of metalliferous ore deposits. See Irving, Smith and Ferguson, no. 549.

Smith, Howard D.

1059. Progress in the Cat Canyon oil field [Santa Barbara County, California] : Western Eng., vol. 3, no. 4, pp. 264-266, 3 figs., October, 1913.

Smith, George Otis.

1060. Thirty-fourth annual report of the Director of the United States Geological Survey to the Secretary of the Interior for the fiscal year ended June 30, 1913. 183 pp., 2 maps. Washington, 1913.

An administrative report summarizing the activities of the Survey during the fiscal year 1912-1913.

1061. The United States Geological Survey and ore deposits: Min. and Sci. Press, vol. 106, p. 22, January 4, 1913.

1062. Field and office methods in the preparation of geological reports : Econ. Geology, vol. 8, no. 3, pp. 264-265, 1913.

1063. Contributions to general geology: Science, new ser., vol. 38, pp. 78-79, JuIy 18, 1913.

Smith, George Otis, and others.

1064. The classification of the public lands: U. S. Geol. Survey, Bull. 537, 197 pp., 8 figs., 1913.

Smith, James Perrin.

1065. The biogenetic law illustrated in the development of fossil cephalopods (abstract) : Geol. Soc. America, Bull., vol. 24, no. 1, p. 129, March 24, 1913.

Smith, Lloyd B.

1066. A peridotite dike in Fayette and Greene counties [Pennsylvania]: Pennsylvania, Topog. and Geol. Survey, Rept. 1910-1912, pp. 151-155, 3 pls. (incl. map), $\dot{2}$ figs., 1912.

Smith, Philip S.

1067. Lode mining near Fairbanks: U. S. Geol. Survey, Bull. 525, pp. 153216, 1 pl., 6 figs., 1913.

1068. The Noatak-Kobuk region, Alaska: U. S. Geol. Survey, Bull. 536, 157 pp., 15 pls. (incl. maps, 2 in pocket), 1 fig. (map), 1913.

Describes the geographic features, the occurrence, character, and relations of Paleozolc, Mesozoic, and Cenozolc sedimentary rocks and of igneous rocks, the gold placers, and other mineral deposits.

1069. Lode mining near Fairbanks [Alaska]: U. S. Geol. Survey. Bull. 542, pp. 137-202, map, 7 figs., 1913.

Describes the geology and the occurrence and character of gold deposits. 
Smith, Philip S.-Continued.

1070. A sketch of the geography and geology of Seward Peninsula, Alaska: U. S. Geol. Survey, Water-Supply Paper 314, pp. 13-15, 32-51, 1 pl. (geol. map), 5 figs., 1913.

1071. The Noatak River, Alaska: Assoc. Am. Geog., Annals, vol. 2, pp. 65-72, 1 fig., [1913].

1072. Field and office methods in the preparation of geological reports (discussion) : Econ. Geology, vol. 8, no. 4, pp. 392-397, 1913.

1073. The fineness of gold in the Fairbanks district, Alaska : Econ. Geology, vol. 8, no. 5, pp. 449-454, pl. (map), 1913.

Smith, Sumner $\mathbf{S}$.

1074. Lode mining in the Willow Creek district [Alaska]: Min. and Sci. Press, vol. 107, pp. 335-337, 4 figs., August 30, 1913.

Smyth, C. H., jr.

1075. The relative solubilities of the chemical constituents of rocks: Jour. Geology, vol. 21, no. 2, pp. 105-120, February-March, 1913.

1076. The chemical composition of the alkaline rocks and its significance as to their origin: Am. Jour. Sci., 4th ser., vol. 36, pp. 33-46, July, 1913.

Snider, L. C.

1077. Petroleum and natural gas in Oklahoma. 1.96 pp., 37 figs., 6 pls. (maps). Oklahoma City, Okla., The Harlow-Ratliff Company, 1913.

1078. The gypsum and salt of Oklahoma: Oklahoma Geol. Survey, Bull. no. 11, 214 pp., 67 figs. (incl. maps), July, 1913.

1079. Rock asphalts of Oklahoma and their use in paving: Oklahoma Geol. Survey, Circ. no. 5, 22 pp., 7 figs., 1913.

1080. Rock asphalt deposits of Oklahoma: Min. and Eng. World, vol. 38, pp. 577-580, 7 figs., March 22, 1913.

1081. Oklahoma gypsum deposits and industry : Eng. and Min. Jour., vol. 95, no. 18, pp. 931-933, 4 figs. (incl. map), May 10, 1913.

Sollas, Igerna B. J.

1082. On Onychaster, a Carboniferous brittle-star: Roy. Soc. London, Phil. Trans., ser. B, vol. 204, pp. 51-62, 2 pls., 5 figs., May 15, 1913.

Describes the structure of Onychaster flexilis Meek and Worthen from the Keokuk beds of Crawfordsville, Ind.

Sosman, R. B., and Merwin, H. E.

1083. Data on the intrusion temperature of the Palisade diabase: Washington Acad. Sci., Jour., vol. 3, no. 14, pp. 389-395, August 19, 1913.

Spearman, Charles.

1084. Ore deposits of the Kirkland Lake district [Ontario] : Canadian Min. Jour., vol. 34, pp. 599-601, 3 figs., October 1, 1913.

Spencer, Arthur C.

1085. The magmatic origin of vein forming waters in southeastern Alaska [reprinted from Am. Inst. Min. Eng., Trans., vol. 36, pp. 364-371, 1906]. In Emmons, S. F., Ore deposits, pp. 582-589, published by the American Institute of Mining Engineers, New York, 1913.

1086. [Notes on the] Ely [district], Nevada: U. S. Geol. Survey, Bull. 529, pp. 189-191, 1913.

Discusses the geology and the character and occurrence of the ores.

1087. Chalcocite enrichment: Econ. Geology, vol. 8, no. 7, pp. 621-652, October, 1913; Washington Acad. Sci., Jour., vol. 3, no. 3, pp. 70-75, February 4, 1913. 
Spencer, Joseph William Winthrop.

1088. Postglacial earth movements about Jake Ontario and the Saint Lawrence River: Geol. Soc. America, Bull., vol. 24, no. 2, pp. 217-228, 1 fig. (map), June 7, 1913.

1089. Relationship of the Great Lake basins to the Niagara limestone: Geol. Soc. America, Bull., vol. 24, no. 2, pp. 229-232, 1. fig. (map), June 7, 1913.

1080. Relationship between terrestrial gravity and observed earth movements of eastern Americal Am. Jour. Sci., 4th ser., vol. 35, pp. 561-573, 1 map, June, 1913.

1091. Outline of the evolution of the Falls of Niagara; contrast with the falls of the Zambesi. (For the Intern. Geol. Cong., Twelfth, Canada.) 8 pp., 2 pls., map. Washington, D. C., Judd \& Detweiler, 1913. [Private publication, copyright, 1913, by author.]

1092. Postglacial earth movements about Lake Ontario and the Saint Lawrence River (discussion by D. W. Johnson and J. W. Spencer): Geol. Soc. America, Bull., vol. 24, no. 4, pp. 714-715, December 23, 1913.

1093. Postglacial changes of level versus recent stability of the Lake Region of America (abstract) ; British Assoc. Adv. Sci., Rept. 82d meeting, pp. $476-477,1913$.

See also Berkey, no. 70 ; Grabau, no. 432 ; and lorre, no. 1167.

Spilsbury, E. Gybbon.

1094. Geological notes on La Luz district of Guanajuato [Mexico] : Mexican Min. Jour., vol. 16, no. 1, p. 22, January, 1913.

Springer, Frank.

1095. Crinoid genus Scyphocrinus and its bulbous root Camarocrinus (abstract) : Geol. Soc. America, Bull., vol. 24, no. 1, pp. 110-111, March 24, 1913.

Springer, J: F.

1096. Sulphur and iron deposits of Virginia: Min. and Eng. World, vol. 38, pp. 528-530, 2 figs., March 15, 1913.

Spurr, J. E.

1097. A consideration of igneous rocks and their segregation or differentiation as related to the occurrence of ores (with discussion by $\mathrm{A} . \mathrm{N}$. Winchell) [reprinted from Am. Inst. Min. Eng., Trans., vol. 33, pp. 288-340, 1063-1064, 1903]. In Emmons; S. F., Ore deposits, pp. 251-304, published by the American Institute of Mining Engineers, New York, 1913.

1098. Genetic relations of the western Nevada ores [reprinted from Am. Inst. Min. Eng., Trans., vol. 36, pp. 372-402, 1906]. In Enmons, S. F., Ore deposits, pp. 590-620, published by the American Institute of Mining Engineers, New York, 1913.

Spurr, J. E., Garrey, G. H., and Fenner, Garence N.

1099. Study of a contact-metamorphic ore-deposit, the Dolores mine, at Matehuala, S. L. P., Mexico (abstract) : Washington Acad. Scl., Jour., vol. 3, no. 4, p. 116, February 19, 1913.

Stalder, J. W.

See also Taff, no. 1144. 
Stansfield, J.

1100. Mineral deposits of the Ottawa district: Intern. Geol. Cong., Twelfth, Guide Book no. 3 (issued by the Canada Geol. Survey), pp. 81-115, maps, pls., figs., 1913.

Stanton, Timothy W.

1101. Some variations in Upper Cretaceous stratigraphy: Washington Acad. Sci., Jour., vol. 3, no. 3, pp. 55-70, February 4, 1913.

Stauffer, Clinton $\mathrm{R}$.

1102. Geology of the region around Hagersville [Ontario]: Intern. Geol. Cong., Twelfth, Guide Book no. 4 (issued by the Canada Geol. Survey), pp. 82-99, 1 map, 1 pl., 1913.

1103. Geology of the region around Port Colborne [Ontario] : Intern. Geol. Cong., Twelfth, Guide Book no. 5 (issued by the Canada Geol. Survey), pp. 47-55, 1 map, 2 pls., 1913.

Stebinger, Eugene.

1104. Control for geologic mapping in the absence of a topographic base map: Econ. Geology, vol. 8, no. 3, pp. 266-271, 1 fig., 1913.

1105. The coal fields of Montana: Am. Inst. Min. Eng., Bull. no. 81, pp. 2329-2359, 3 figs., September, 1913.

Pre-Wisconsin glacial drift in the region of Glacier National Park, Montana. See Alden and Stebinger, no. 11.

Sterrett, Douglas B.

1106. Mica in Idaho, New Mexico, and Colorado: U. S. Geol. Survey; Bull. 530, pp. 375-390, 3 figs., 1913.

1107. Gems and precious stones; mica: U. S. Geol. Survey, Mineral Resources, 1912, pt. 2, pp. 1023-1060, 1079-1091, 1913.

Stevens, Blamey.

1108. The ultimate source of metals: Am. Inst. Min. Eng., Bull. no. 75, pp. 331-343, 1 fig., March, 1913 ; Trans., vol. 44, pp. 663-675, 1913.

1109. The nature of replacement (discussion of paper by W. Lindgren): Econ. Geology, vol. 8, no. 4, pp. 397-398, 1913.

Stevens, E. A.

1110. Basaltic zones as guides to ore deposits in the Cripple Creek district, Colorado [reprinted from Am. Inst. Min. Eng., Trans., vol. 33, pp. 686-698, 1903]. In Emmons, S. F., Ore deposits, pp. 411-423, 4 figs., published by the American Institute of Mining Engineers, New York, 1913.

Stevenson, John J.

1111. The formation of coal beds; IV: Am. Philos. Soc., Proc., vol. 52, pp. 31-162, 1913.

1112. Formation of coal beds [reprinted from Am. Philos. Soc., Proc., vol. 50, pp. 1-116, 519-643, 1911; vol. 51, pp. 423-553, 1912; vol. 52, pp. 31-162, 1913. 529 pp. Lancaster, Pa., The New Era Printing Company, 1911-1913.

Stewart, Charles A.

1113. Magmatic differentiation at Silverbell, Arizona: Science, new ser., vol. 37, pp. 338-340, February 28, 1913.

1114. The formation of the secondary silicate zone in contact-metamorphic ore deposits: Econ. Geology, vol. 8, no. 5, pp. 501-507, 1913.

1115. The extent of the Cordilleran ice sheet: Jour. Geology, vol. 21, no. 5, pp. $427-430,1$ fig., 1913. 
Stewart, R. B.

1116. The outlying cobalt-silver areas [Ontario]; the Shining Tree silver area: Ontario, Bureau of Mines, Rept., vol. 19, pt. 2, pp. 187-193, 5 figs., 1913.

1117. The West Shining Tree gold area [Ontario]: Ontario, Bureau of Mines, Twenty-second Ann. Rept., vol. 22, pt. 1, pp. 233-237, 1. sketch map, Toronto, 1913.

Stock, Chester. Describes the geology and the occurrence of gold deposits.

1118. Nothrotherium and Megalonyx from the Pleistocene of southern California: California, Univ., Dept. Geology, Bull., vol. 7, no. 17, pp. 341-358, 18 figs., September 19, 1913.

Stone, Ralph W.

1119. Sand and gravel; gypsum; lime: U. S. Geol. Survey, Mineral Resources, 1912, pt. 2, pp. 621-668, 1913.

Stoner, Reginald C.

1120. Recent observations on the mode of accumulation of the Pleistocene bone deposits of Rancho La Brea: Callifornia, Univ., Dept. Geology, Bull., vol. 7 , no. 20, pp. 16-21, 6 pls., October 31., 1913.

Monterey series on the south side of Mount Diablo, California (abstract). See Kew and Stoner, no. 597.

Stopes, Marie C.

1121. Excursion in eastern Quebec and the maritime provinces; fern ledges [at St. John, New Brunswick]: Intern. Geol. Cong., Twelfth, Guide Book no. 1 (issued by the Canada Geol. Survey), pp. 390-395, map, 1913.

1122. Palaebotany versus stratigraphy in New Brunswick (abstract) : British Assoc. Adv. Sci., Rept. 82d meeting, p. 471, 191.3.

Storms, William H.

1123. Persistence of ore in depth: Min. and Sci. Press, vol. 106, 1p. 349-351, March 1, 1913.

1124. Is geology a success as guide to ore deposits?: Min. and IEng. World, vol. 38, pp. 427-428, March 1, 1913.

1125. The Trinity-Balaklala-Vulcan mines, Shasta County, California: Min. and Sci. Press, vol. 107, pp. 408-411, 3 figs., September 13, 1913.

Includes notes on the geology of the Shasta copper belt.

1126. Geology of the Woody copper district, California : Eng. and Min. Jour., vol. 96 , p. 635 , October $4,1913$.

Stose, George W.

1127. Geology of the salt and gypsum deposits of southwestern Virginia: U. S. Geol. Survey, Bull. 530, pp. 232-255, 5 figs., 1913; Virginia Geol. Survey, Bull. no. 8, pp. 51-73, 5 figs., 1913; (abstract), Washington Acad. Sci., Jour., vol. 3, no. 4, pp. 117-118, February $19,1913$.

1128. Field and office methods in the preparation of geological reports; a method of geologic mapping and note taking: Econ. Geology, vol. 8, no. 4, pp. 389-392, 1913.

1129. Apishapa, Colo., folio (abstract) : Washington Acad. Sci., Jour., vol. 3, no. 4, p. 117, February 19, 1913.

Stow, Audley H.

1130. Mining in the Pocahontas [coal] field: Coal Age, vol. 3, no. 16, pp. 594-600, 11 figs., April 19, 1913. 
Surr, Gordon.

1131. Lapis lazuli in southern California: Min. and Eng. World, vol. 39, pp. 1153-1154, December 27, 1913.

Swartz, Charles K.

1132. Lower Devonian; introduction, general relations of the Devonian: Maryland Geol. Survey, Lower Devonian, pp. 23-33, map, 2 figs., 1913.

1133. Correlation of the Lower Devonian: Maryland Geol. Survey, Lower Devonian, pp. 96-132, 2 pls., 1913.

1134. Systematic paleontology of the Lower Devonian deposits of Maryland; Coelenterata: Maryland Geol. Survey, Lower Devonian, pp. 195227, 3 figs., 16 pls. . (in plates volume), 1913.

1135. Correlation of the Upper Devonian: Maryland Geol. Survey, Middle and Upper Devonian, pp. 410-444, 1 fig., 1 pl., 1913.

1136. Local sections of the Upper Devonian [of Maryland] : Maryland Geol. Survey, Middle and Upper Devonian, pp. 445-534, 1 pl. (in pocket), 1913.

1137. Systematic paleontology of the Upper Devonian deposits of Maryland; Pisces: Maryland Geol. Survey, Middle and Upper Devonian, pp. 700-701, 1 pl. (in plates volume), 1913.

Systematic paleontology of the Upper Devonian deposits of Maryland. See Clarke and Swartz, no. 214.

The Upper Devonian deposits of Maryland. See Prosser and Swartz, no. 936.

The Middle Devonian deposits of Maryland. See Prosser, Kindle, and Swartz, no. 937.

The Lower Devonian deposits of Maryland. See Schuchert and others, no. 1029.

Swartz, C. K., and others.

1138. Lower Devonian; introduction : Maryland Geol. Survey, Lower Devonian, pp. 23-66. 2 figs., 10 pls., 1913.

1139. Local sections of the Lower Devonian [of Maryland]: Maryland Geol. Survey, Lower Devonian, pp. 133-190, 1 pl. (in pocket), 1913.

Sweezey, R. 0.

1140. Molybdenite deposit at Turn Back Lake, Quebec: Canadian Min. Jour., vol. 34, pp. 190-191, March 15, 1913.

Taber, Stephen.

1141. Geology of the gold belt in the James River basin, Virginia: Virginia Geol. Survey, Bull. no. 7, 271 pp., 10 pls., 23 figs., 1913.

1142. The South Carolina earthquake of January 1, 1913: Seism. Soc. America, Bull., vol. 3, no. 1, pp. 6-13, 1 fig.; March, 1913.

1143. Earthquakes in Buckingham County, Virginia: Seism. Soc. America, Bull., vol. 3, no. 3, pp. 124-133, 1 pl., 1 fig., 1913.

Explains the earthquakes as due to faulting in the Arvonia slate belt in the Piedmont/ region of Virginia.

Geology of the titanium and apatite deposits of Virginia. See Watson and Taber, no. 1247.

Magmatic names proposed in the quantitative system of classification for some new rock types in Virginia. See Watson and Taber, no. 1248.

Igneous complex of high titanium-phosphorus-bearing rocks of Amherst-Nelson counties, Virginia (abstract). See Watson and Taber, no. 1249. 
Taff, J. A.

1144. Eocene of the Coalinga-Cantua district, Fresno County, California (abstract, with discussion by F. M. Anderson, A. C. Lawson, and W. Stalder) : Geol. Soc. America, Bull., vol. 24, no. 1, pp. 127128, March 24, 1913.

Portland cement materials and industry; Texas. See Eckel, no. 342. See also Ruckman, no. 1000 .

Tarr, Ralph Stockman.

1145. Glaciers and glaciation of Alaska: Assoc. Am. Geog., Aunals, vol. 2, pp. 3-24, 1 pl., [1913].

Tarr, R. S., and Martin, Lawrence.

1146. Glacial deposits of the continental type in Alaska: Jour. Geology, vol. 21 , no. 4, pp. 289-300, 4 figs., 1913.

1147. An effort to control a glacial stream: Assoc. Am. Geog., Annals, vol. 2, pp. 25-40, 11 pls., [1913].

Includes various notes on glaciers of Kenal Peninsula, Alaska.

Taylor, Frank Bursley.

1148. The glacial and postglacial lakes of the Grent Lakes region: Smithsonian Inst., Ann. Rept. for 1912, pp. 291-327, 10 figs., 1913.

1149. Niagara Falls and gorge: Intern. Geol. Cong., Twelfth, Guide Book no. 4 (issued by the Canada Geol. Survey), pp. 8-70, 2 maps, 1 pl., figs., 1913.

1150. Moraines north of Toronto [Ontario]: Ontario, Bureau of Mines, 'Twenty-second Ann. Rept., vol. 22, pt. 1, pp. 25ti-260, 3 figs., Toronto. 1913 ; Intern. Geol. Cong., Twelfth, Guide Book no. 6. (issued by the Ontario Bur. Mines), pp. 35-42, 3 figs., 1913.

1151. The moraine systems of southwestern Ontario: Canadian Inst., Trans., vol. 10, pt. 1, pp. 57-79, 4 pls., 4 maps, November, 1913.

1152. Characters of the older sections of the Niagara gorge and their correlation with Great Lakes. history (abstract) : Geol. Soc. America, Bull., vol. 24, no. 4, pp. 702-703, December 23, 1.913.

1153. Map of the old distributaries of the St. Clair and Detroit rivers (abstract) : Michigan Acad. Sci., 14th Rept., p. 142, 1912.

Description of the Niagara quadrangle, New York. See Kindle and Taylor, no. 619 .

Teets, D. D., jr.

Cabell, Wayne, and Lincoln counties [West Virginia]. See Krebs and Teets, no. 640 .

Templeton, E. C.

1154. General geology of the San Jose and Mount Familton quadrangles (abstract) : Geol. Soc. America, Bull., vol. 24, no. 1, p. 96, March 24, 1913.

Thomas, A. O.

1155. The relation of the Lime Creek shales to the Cedar Valley limestones of Floyd County, Iowa (abstract): Science, new ser., vol. 37, p. 459, March 21, 1913.

Thomas, Kirby.

1156. Zinc ore deposits in Boone and Marion counties, Arkansas: Min. and Sci. Press, vol. 107, pp. 854-855, November 29, 1913.

$38416^{\circ}-$ Bull. 584-14-7 
Thompson, Arthur P.

1157. The relation of pyrrhotite to chalcopyrite and other sulphides: School of Mines Quar., vol. 34, no. 4, pp. 385-395, 3 pls., July, 1913.

Tight, Dexter J.

Drainage changes in the Moots Run area, Licking County, Ohio. See Nixon and Tight, no. 850 .

Tilton, John L.

1158. A new section south from Des Moines, Iowa : Science, new ser., vol. 38, pp. 133-135, July 25, 1913.

1159. The proper use of the geological name, Bethany (abstract) : Science, new ser., vol. 38, p. 241, August 15, 1913.

1160. A Pleistocene section from Des Moines south to Allerton (abstract) : Science, new ser., vol. 38, p. 241, August 15, 1913.

Todd, J. E.

1161. Evidence of Pleistocene crustal movements in the Mississippi Valley: Kansas, Univ., Sci. Bull., vol. 6, no. 4, pp. 375-379, January, 1912 [1913].

1162. More about septarian structure : Geol. Mag., dec. 5, vol. 10, pp. 361-364, 3 figs., August, 1913.

1163. The "moraines" of Kansas (abstract): Science, new ser., vol. 37, p. 457, March 21, 1913.

1164. 'Traces of an early Wisconsin flood (abstract): Science, new ser., vol. 37, p. 457, March 21, 1913.

Tolman, C. F.

1165. Secondary sulphide enrichment of ores: Min. and Sci. Press, vol. 106, pp. 38-43, 141-145, 178-181, 11 figs., January 4, 18, and 25, 1913.

Torre, C. de la.

1166. Comprobation de l'existence d'un horizon jurassique dans la région occidentale de Cuba (with discussion) : Intern. Geol. Cong., XI, Stockholm 1910, Compt. rend., pp. 1021-1022, 1912.

Confirms the occurrence of Jurassic strata in western Cuba.

1167. Restoration of Megalocnus rodens and discovery of a continental Pleistocene fauna in central Cuba (with discussion by J. W. Spencer) : Intern. Geol. Cong., XI, Stockholm 1910, Compt. rend., pp. 1023-1024, 1912.

Tovote, Wm. L.

Confirms the occurrence of Pleistocene Mammalia in central Cuba.

1168. Metallic minerals as precipitants of silver and gold (discussion): Econ. Geology, vol. 8, no. 7, p. 720, October, 1913.

Trowbridge, Arthur C.

1169. Some partly dissected plains in Jo Daviess County, Illinois: Jour. Geology, vol. 21, no. 8, pp. 731-742, 1 fig., November-December, 1913.

Laboratory exercises in structural and historical geology; a laboratory manual based on folios of the United States Geological Survey, for use with classes in structural and historical geology. See Salisbury and Trowbridge, no. 1002.

Trumbull, L. W.

1170. Prospective oil fields at Upton, Weston County, Buck Creek, Niobrara County, Rattlesnake Mountains, Natrona County, La Barge, Lincoln County [Wyoming]: Wyoming, Geologist's office, Ser. B, Bull. no. 5, 15 pp., 4 sketch maps, 1913. 
Turrentine, J. W.

1171. The occurrence of potassium salts in the salines of the United States:

U. S. Dept. Agr., Bur. Soils, Bull. no. 94, 96 pp., 1913.

Includes an account of the geology of saliferous deposits in the United States.

Twenhofel, W. H.

1172. Excursion in eastern Quebec and the maritime provinces; Arisaig (pp. 288-312) : Intern. Geol. Cong.; Twelfth, Guide Book no. 1 (issued by the Canada Geol. Survey), 1913.

Twitchell, M. W.

1173. The mineral industry of New Jersey for 1912 : New Jersey Geol. Survey, Bull. 11, 43 pp., 1 pl. (map), 1913.

Tyrrell, J. B.

1174. The gold of the Klondike: Roy. Soc. Canada, Proc. and Trans., 3d ser., vol. 6, sect. 4 , pp. 29-59, 2 pls., 1912.

Describes the geology and physlographic development of the district, and the occurrence, formation, and productiveness of the placer deposits.

1175. Hudson Bay exploring expedition, 1912: Ontario, Bureau of Mines, Twenty-second Ann. Rept., vol. 22, pt. 1, pp. 161-209, 36 figs., 2 folded maps, Toronto, 1913.

Includes observations on the geology of the region traversed in Manitoba and northern Ontario and descriptions of new species and notes on other species of Ordovician fossils (Manitoba) and Silurian fossils (Patricia; Ontario) by W. A. Parks.

1176. 'The occurrence of gold in Ontario: Inst. Min. and Metall., Bull. no. 110, pp. 1-12, 1 fig., November 13, 1913.

Gives an account of the geology of the gold-bearing districts of Ontario.

1177. The Patrician glacier south of Hudson Bay: Intern. Geol. Cong., Twelfth, Canada, 10 pp., 1913 (advance copy).

Describes drift deposits and glacial phenomena which indicate a northward flowing glacier south of Hudson Bay to which the term Patricia glacier is given.

1178. The Coppermine country: Canadian Min. Jour., vol. 34, pp. 117-121, 147-153, 5 figs. (incl. maps), February 15 and March 1, 1913.

1179. Silver veins in South Lorrain, Ont, Canadian Min. Jour., vol. 34, pp. 329-330, June 1, 1913.

Udden, J. A.

1180. On the trail of a catastrophe: The Texas Magazine, vol. 7, no. 3, pp. 242-244, 1 fig., January, 1913.

Describes a deposit of volcanic ash in Kent County, Texas.

1181. Blocks and segments: Science, new ser., vol. 37, pp. 709-710, May 9, 1913.

1182. The effect of leaching on drift pebbles: Jour. Geology, vol. 21, no. 6, pp. 564-567, September-October, 1913.

Uglow, W. L.

1183. Port Arthur to Winnipeg via Canadian Northern Railway: Intern. Geol. Cong., Twelfth, Guide Book no. 8 (issued by the Canada Geol. Survey), pp. 37-69, maps, figs., 1913.

1184. A review of the existing hypotheses on the origin of the secondary silicate zones at the contacts of intrusives with limestones: Econ. Geology, vol. 8, nos. 1 and 3, pp. 19-50, 215-234, 2 figs., 1913.

1185. Hydrothermal alteration (discussion): Econ. Geology, vol. 8, no. 8, pp. 797-800, December, 1913. 
Ulrich, E. O.

1186. Index to "Revision of the Paleozoic systems": Geol. Soc. America, Bull., vol. 24, no. 4, pp. 625-668, December 26, 1913.

The "Revision of the Paleozoic systems" was printed in vol. 22, pp. 281-680 of the Bulletin of the Geological Society of America.

1187. The Ordovician-Silurian boundary: Intern. Geol. Cong., Twelfth, Canada, 50 pp., 1913 (advance copy).

1188. The Medina problem (abstract) : Geol. Soc. America, Bull., vol. 24, no. 1, pp. 107-108, March 24, 1913.

1189. Nomenclature, structure, and classification of the Cremacrinidæ (abstract) : Geol. Soc. America, Bull., vol. 24, no. 1, pp. 109-110, March 24, 1913.

Portland cement materials and industry; Tennessee. See Eckel, no. 342.

Ulrich, E. O., and Bassler, R. S.

1190. Systematic paleontology of the Lower Devonian deposits of Maryland; Bryozoa, Ostracoda: Maryland Geol. Survey, Lower Devonian, pp. 259-290, 513-542, 16 pls. (in plates volume), 1913.

1191. Systematic paleontology of the Middle Devonian deposits of Maryland; Bryozoa: Maryland Geol. Survey, Middle and Upper Devonian, pp. 123-124, 1 pl. (in plates volume), 1913.

Ulrich, E. O., and Butts, Charles.

1192. [Geologic sections in southeastern Tennessee]: Tennessee State Geol. Survey, Bull. 16, pp. 32-43, 1913.

Umpleby, Joseph B.

1193. Geology and ore deposits of Lemhi County, Idaho: U. S. Geol. Survey, Bull. 528, 182 pp., 23 pls., 24 figs., 1913.

1194. A preliminary account of the ore deposits of the Loon Creek district, Idaho: U. S. Geol. Survey, Bull. 530; pp. 66-74, 1 fig., 1913.

1195. Some ore deposits in northwestern Custer County, Idaho: U. S. Geol. Survey, Bull. 539, 104 pp., 10 pls., 4 figs., 1913.

1196. The old erosion surface in Idaho: Jour. Geology, vol. 21, no. 3, pp. 224-231, 1913.

Recent literature on economic geology. See Knopf and Umpleby, no. 631.

Umpleby, J. B., Schaller, W. T., and Larsen, E. S.

1197. Custerite; a new contact metamorphic mineral: Am. Jour. Sci., 4th ser., vol. 36, pp. 385-394, October, 1913.

Ungemach, $\mathrm{H}$.

1198. Contribution à la minéralogie du Mexique: Soc. Cient. "Antonio Alzate," Mem. y Rev., t. 31, nos. 7-12, Rev. pp. 1-36, 26 figs., January, 1912.

Describes the crystallographic features of some minerals of Mexico.

United States Geological Survey.

1199. Contributions to economic geology (short papers and preliminary reports), 1911; Part I, Metals and nonmetals except fuels: U. S. Geol. Survey, Bull. 530, 400 pp., 7 pls., 51 figs., 1913.

The papers in this bulletin have been entered under the individual authors. Interspersed are lists of the Survey publications on various economic products. 


\section{United States Geological Survey-Continued.}

1200. Contributions to economic geology (short papers and preliminary reports), 1911; Part II, Mineral fuels: U. S. Geol. Survey, Bull. 531, 361 pp., 24 pls., 10 figs., 1913.

The papers in this bulletin have been entered under the individual authors.

1201. Miscellaneous analyses of coal samples from various fields of the United States: U. S. Geol. Survey, Bull. 531, pp. 331-335, 1913.

1202. Mineral resources of the United States, Calendar year, 1912; Part I, Metals, 1079 pp., 3 pls., 13 figs.; Part II, Nonmetals, 1218 pp., 8 pls., 11 figs., 1913.

Upham, Warren.

1203. Fields of outflow of the North American ice sheet: Intern. Geol. Cong., Twelfth, Canada, 8 pp., 1913 (advance copy).

1204. The Sangamon interglacial stage in Minnesota and westward: Intern. Geol. Cong., Twelfth, Canada, 11 pp., 1913 (advance copy).

a Discusses the occurrence and relations of drift deposits and phenomena assigned to the Sangamon interglacial stage and the length and cause of the ice age.

1205. The Sangamon interglacial stage in Minnesota (abstract): Science, new ser., vol. 37, p. 457, March 21, 1913.

1206. The relation of the Keewatin and Labrador areas of glaciation (abstract) : Science, new ser., vol. 37, p. 457, March 21, 1913.

Urbina, $\mathrm{F}$.

Informe acerca de los recursos naturales de la parte Norte de la Baja California, especialmente del Delta del Río Colorado. See Bonillas and Urbina, no. 84 .

Van Hise, Charles Richard.

1207. The influence of applied geology and the mining industry upon the economic development of the world: Intern. Geol. Cong., XI, Stockholm, 1910, Compt: rend., pp. 259-261, 1912.

Van Horn, Frank R.

1208. A new occurrence of silver, copper, and cobalt minerals in Mexico:

Am. Jour. Sci., 4th ser., vol. 35, pp. 23-30, 3 figs., January, 1913.

Describes minerals from the Veta Rica mine, Sierra Mojada, Coa. huila. Mexico.

1209. New occurrence of pisanite and some large staurolites from Ducktown, Tennessee (abstract): Geol. Soc. America, Bull., vol. 24, no. 4, p. 686, December 23, 1913.

Van Ingen, G. See Woodman, no. 1323.

Van Orstrand, C. E.

The determination of the order of agreement between observation and theory in mineral analyses. See Wright and Van Orstrand, no. 1343.

Vaughan, Thomas Wayland.

1210. Studies of the geology and of the Madreporaria of the Bahamas and of southern Florida: Carnegie Inst. Washington, Yearbook no. 11, 1912, pp. 153-162, [1913].

1211. Remarks on thë geology of the Bahama Islands, and on the formation of the Floridan and Bahaman oolites (abstract): Washington Acad. Sci., Jour., vol. 3, no. 10, pp. 302-304, May 19, 1913. 
Vaughan, Thomas Wayland-Continued.

1212. Investigations of the geology and geologic processes of the reef tracts and adjacent areas in the Bahamas and Florida: Carnegie Inst. Washington, Yearbook no..12, pp. 183-184, 1913.

A deep boring in Bermuda Island. See Pirsson and Vaughan, no. 921.

Victorin, Frère Marie.

1213. Les "galets"; observations sur la géologie et "la flore des terrains désertiques aux environs de St.-Jérôme, P. Q.: Soc. Géog. Québec, Bull., vol. 7, no. 1, pp. 7-22, 6 figs., 1913.

Includes notes on the geology of the vicinity of St. Jerome, Quebec.

Villafaña, Andres.

1214. Estudio de la infiltración de aguas en las minas de la región Noroeste del Mineral de Zacatecas: Soc. Cient. "Antonio Alzate," Mem. y Rev., t. 32, nos. 1-3, pp. 21-26, 1 pl. (map), February, 1912.

Discusses water in the mines of the mineral district of Zacatecas, Mexico. Includes notes on the rocks.

1215. Algunos datos acerca de la Sierra Madre Occidental en el Estado de Durango (abstract) : Soc. Geol. Mexicana, Bol., t. 8, pt. 1, pp. vii-viii, 1912.

Gives notes on the geology of the Sierra Madre Occidental, State of Durango, Mexico.

Visher, S. S.

1216. The history of the bajadas of the Tucson bolson of Arizona (abstract) : Science, new ser., vol. 37, p. 459, March 21, 1913.

Von Engeln, O. D.

1217. Dynamic geology (with references to structural phenomena in their relation to processes); a recitation text. 160 pp., 50 figs. [Private publication]. Copyright, 1913.

W,, R. C.

1218. The Twelfth International Geological Congress: Nature, vol. 92, pp. $7-9,1913$.

Wade, W. Rogers.

1219. Minerals of the Tres Hermanas district [New Mexico] : Eng. and Min. Jour., vol. 96, pp. 589-590, September 27, 1913.

Includes notes on the geology and the occurrence of zinc ores.

Wadsworth, M. E.

1220. Microscopy in economic geology: Eng. and Min. Jour., vol. 96, p. 31, July 5, 1913.

Waggaman, William Henry.

1221. A report on the phosphate fields of South Carolina: U. S. Dept. Agr., Bull. no. 18, 12 pp., 3 pls., 1913.

Waitz, Paul.

1222. Excursion geologica a la parte poniente de la Sierra de Santa Catarina: Soc. Geol. Mexicana, Bol., t. 8, pt. 1, pp. 1-8, 5 pls., 1912.

Describes the geology of the western part of the Sierra de Santa Catarina, Mexico, D. F.

Waitz, Paul, and Hijar y Haro, L.

1223. Algunos datos geológicos sobre la región minera de Yesca (Tepic) de los alrededores de la mina "Nueva Buenavista y Anexas": Soc. Geol. Mexicana, Bol., t. 8, pt. 1, pp. 71-96, 10 pls., 1912

Gives geologic data on the mineral district of Yesca, Tepic, Mexico. 
Walcott, Charles D.

1224. Cambrian geology and paleontology, II ; no. 11, New Lower Cambrian subfauna: Smithsonian Misc. Coll., vol. 57, no. 11, pp. 309-326, 5 pls., July 21, 1913.

Describes new species mainly from the Robson Peak district, Alberta.

1225. Cambrian geology and paleontology, II ; no. 12, Cambrian formations of the Robson Peak district, British Columbia and Alberta, Canada: Smithsonian Misc. Coll., vol. 57, no. 12, pp. 327-343, 5 pls., July 24, 1913.

1226. The monarch of the Canadian Rockies; the Robson Peak district of British Columbia and Alberta: Nat. Geog. Mag., vol. 24, no. 5, pp. 626-639, 11 figs., 1913.

Includes notes on the physiographic features and on the occurrence of Cambrian fossils.

1227. Cambrian fossils from British Columbia (abstract) : Science, new ser., vol. 37, pp. 724-725, May 9, 1913.

Walker, Bryant.

1228. The Unione fauna of the Great Lakes: Nautilus, vol. 27, pp. 18-23, $29-34,40-47,56-59$, 5 figs., 1913.

Includes notes on the preglacial distribution.

Walker, T. L.

1229. The pre-Cambrian of Parry Island and vicinity: Intern. Geol. Cong., Twelfth, Guide Book no. 5 (issued by the Canada Geol. Survey), pp. 98-100, 1 map, 1 fig., 1913.

Wallace, R. C.

1230. Pseudobrecciation in Ordovician limestones in Manitoba: Jour. Geology, vol. 21, no. 5, pp. 402-421, 7 figs., 1913.

Shows that the appearance of brecciation is due to partial dolomitlzation of the limestone contemporaneously with its formation.

1231. A physico-chemical contribution to the study of dolomitization : Intern. Geol. Cong., Twelfth, Canada, 10 pp., 6 figs., 1913 (advance copy).

Waring, Clarence A.

1232. Structural geology south of the Santa Susana district [California]: Western Eng., vol. 3, no. 6, pp. 470-471, 1. fig., December, 1.913.

Waring, Gerald A.

1233. Geology and water resources of a portion of south-central Washington: U. S. Geol. Survey, .Water-Supply Paper 316, 46 pp., 1 pl., 1. fig. (maps), 1913.

Warren, Charles H.

1234. Petrology of the alkali-granites and porphyries of Quincy and the Blue Hills, Mass., U. S. A. : Am. Acad. Arts and Sci., Proc., vol. 49, no. 5, pp. 203-331, 6 figs., 2 pls., September; 1913.

Washington, Henry $\mathrm{S}$.

1235. The distribution of the elements in igneous rocks [reprinted from Am. Inst. Min. Eng., Trans., vol. 39, pp. 735-764, 1909]. In Emmons, S. F., Ore deposits, pp. 729-758, published by the American Institute of Mining Engineers, New York, 1913.

1236. Relations of the feldspars, lenads, and zeolites (abstract) : New York Acad. Scl., Annals, vol. 22, p. 345, April 20, 1913. 
Washington, H. S., and Larsen, E. S.

1237. Magnetite basalt from North Park, Colorado: Washington Acad. Sci., Jour., vol. 3, no. 17, pp. 449-452, October 19, 1913.

Watkins, Joel H.

1238. Bauxite near Elizabethtown, Tennessee: Eng. and Min. Jour., vol. 95, no. 12, pp. 604-605, 2 figs., March 22, 1913.

1239. New occurrence and use of halloysite [Chattooga County, Georgia]: Min. and Eng. World, vol. 38, pp. 721-722, 3 figs., 1913.

Watson, Thomas Leonard.

1240. Biennial report on the mineral production of Virginia during the calendar years 1911 and 1912: Virginia Geol. Survey, Bull. no. 8, 76 pp., 2 pls., 8 figs., 1913.

1241. The mineral resources of Virginia: Min. and Sci. Press, vol. 106, pp. 898-900, 947-949, 5 figs., June 14; vol. 107, pp. 14-15, July 5, 1913.

1242. A meteoric iron from Paulding County, Georgia: Am. Jour. Sci., 4th ser., vol. 36, pp. 165-168, 2 figs., August, 1913.

Watson, Thomas L., and Cline, Justus H.

1243. Petrology of a series of igneous dikes in central western Virginia: Geol. Soc. America, Bull., vol. 24, no. 2, pp. 301-334, 3 pls., 5 figs., June 16, 1913; (abstract), Geol. Soc. America, Bull., vol. 24, no. 4, pp. 682-683, December 23, 1913.

1244. Normal faulting in the Cambrian of northern Piedmont, Virginia: Virginia, Univ., Pub., Philos. Soc., Bull., Sci. Ser., vol. 1, no. 16, pp. 341-347, 3 figs. (incl. map), May, 1913.

1245. Drainage changes in the Shenandoah Valley region of Virginia: Virginia, Univ., Pub., Philos. Soc., Bull., Sci. Ser., vol. 1, no. 17, pp. 349-363, 7 pls. (incl. map), 5 figs., July, 1913.

Watson, Thomas L., and Hess, Frank L.

1246. Zirconiferous sandstone near Ashland, Virginia: U. S. Geol. Survey, Bull. 530, pp. 165-171, 1913. Virginia Geol. Survey, Bull. no. 8, pp. 40-50, 2 pls., 2 figs., 1913.

Watson, Thomas Leonard, and Taber, Stephen.

1247. Geology of the titanium and apatite deposits of Virginia: Virginia Geol. Survey, Bull. no. 3-A, 308 pp., 37 pls. (pl. 1, map in pocket), 22 figs. (incl. maps), 1913.

1248. Magmatic names proposed in the quantitative system of classification for some new rock types in Virginia: Virginia, Univ., Philos. Soc., Bull., Sci. Ser., vol. 1, no. 14, pp. 331-333, February, 1913.

1249. Igneous complex of high titanium-phosphorus-bearing rocks of Amherst-Nelson counties, Virginia (abstract) : Geol. Soc. America, Bull., vol. 24, nò. 4, p. 682, December 23, 1913.

Watts, A. S.

1250. Mining and treatment of feldspar and kaolin in the southern Appalachian region: U. S. Bur. Mines, Bull, 53, 170 pp., 16 pls., 12 figs., 1913.

Weaver, Charles E.

1251. Geology and ore deposits of the Covada mining district: Washington Geol. Survey, Bull. no. 16, 87 pp., 5 pls., 3 figs., 1913.

1252. Preliminary report on the Tertia:y paleontology and stratigraphy of southwestern Washington (abstract): Geol. Soc. America, Bull., vol. 24, no. 1, pp. 131-132, March 24, 1913. 
Weed, Walter Harvey.

1253. Influence of country rock on mineral veins [reprinted from Am. Inst. Min. Eng., Trans., vol. 31, pp. 634-653, 1902]. In Emmons, S. F., Ore deposits, pp. 216-234, 8 figs., publshed by the American Institute of Mining Engineer's, New York, 1913.

1254. Ore deposits near jgneous contacts (with discussion by W. L. Austin) [reprinted from Am. Inst. Min. Eng., Trans., vol. 33, pp. 715-746, 1070-1077, 1903]. In Emmons, S. F., Ore deposits, pp. 364-402, published by the American Institute of Mining Engineers, New York, 1913.

1255. Ore deposition and vein enrichment by ascending hot waters [reprinted from Am. Inst. Min. Eng., Trans., vol. 33, pp. 747-754, 1903]. In Emmons, S. F., Ore deposits, pp. 403-410, published by the American Institute of Mining Engineers, New York, 1913.

1256. Geology of the copper mines of Butte, Montana : Min. and Eng. World, vol. 38, pp. 110-112, 1 map, January 18, 1913.

1257. "Chimney" or "pipe" deposits in the porphyries: Min. and Eng. World, vol. 38, pp. 375-378, 5 figs., February. 22, 1913.

Gives notes on copper deposits of Arizona.

1258. Geology and ore deposits of the Butte district, Montana (abstract) : Washington Acad. Sci., Jour., vol. 3, no. 12, pp. 363-364, June 19, 1913.

Portland cement materials and industry; Montana. See Eckel, no. 342.

Wegemann, Carroll $\mathrm{H}$.

1259. The Barber coal field, Johnson County, Wyoming: U. S. Geol. Survey, Bull. 531, pp. 262-2\$4, 3 pls. (map and sections), 1913.

Weidman, Samụel.

1260. The Pleistocene succession in Wisconsin (abstract) : Science, new ser., vol. 37, pp. 456-457, March 21, 1913 ; Geol. Soc America, Bull., vol. 24, no. 4, pp. 697-698, December 23, 1913.

Wells, Horace L.

1261. Note on artificial sperrylite: Am. Jour. Sci., 4th ser., vol. 35, pp. 171172, February, 1913.

Wells, Roger C.

1262. Electrochemical activity between solutions and ores: Econ. Geology, vol. 8 , no. 6, pp. 571-577, September, 1913.

1263. A new occurrence of cuprodescloizite: Am. Jour. Sci., 4th ser., vol. 36 , pp. 636-638, December, 1913.

Describes the characters and composition of cuprodescloizite from Bisbee, Ariz.

Westcott, Henry P.

1264. Handbook of natural gas. 529 pp., 156 figs. Published by the Metric Metal Works, Erie, Pennsylvania, 1913.

Westgate, Lewis G., and Branson, E. B.

1265. The later Cenozoic history of the Wind River Mountains, Wyoming: Jour. Geology, vol. 21, no. 2, pp. 142-159, 9 figs., February-March, 1913. 
Wherry, Edgar T.

1266. North border relations of the Triassic in Pennsylvania: Acad. Nat. Sci., Philadelphia, Proc., vol. 65, pt. 1, pp. 114-125, 1 pl. (map), 1. fig., 1913.

1267. Zur Nomenklatur der. Mineralvarietäten und Kolloidmineralien: Centralbl. Mineralogie, no. 17, pp. 51S-519, September 1, 1913.

Proposes a method for designating colloid minerals.

Whinery, s.

Clinton iron ore deposits in Kentucky and Tennessee (with discussion by G. MacFarlane) : Am. Inst. Min. Eng., Trans., vol. 44, pp. 25-26, 889,1913 . See no. 1192 of the bibliography for 1912, U. S. Geol. Survey, Bull. 545.

Whitbeck, Ray Hughes.

1268. The geography and industries of Wisconsin: Wisconsin Geol. and Nat. Hist. Survey, Bull. no. 26, 94 pp., 48 figs., 19 pls., 1913.

1269. Mammoth Cave: Jour. Geography, vol. 11, pp. 327-341, 4 figs., June, 1913.

White, David.

1270. Excursion in eastern Quebec and the maritime provinces; the flora of the Gaspe sandstone (pp. 108-110) ; the Horton flora (pp. 144146); note on the flora of the Coal Measures (pp. 250-251): Intern. Geol. Cong., Twelfth, Guide Book no. 1 (issued by the Canada Geol. Survey), 1913.

1271. The fossil flora of West Virginia: West Virginia Geol. Survey, vol. 5 (A), pp. 390-453, 1913.

\footnotetext{
A list of the known fossil plants of West Virginia from the Carbo. niferous and Pleistocene.
}

1272. Roots in the underclays of coals (abstract) : Geol. Soc. America, Bull., vol. 24, no. 1, pp. 114-115, March 24, 1913.

1273. Pottsville-Allegheny boundary in the interior province (abstract) : Geol. Soc. America, Bull., vol. 24, no. 4, p. 716, December 23, 1913.

1274: Roots in the underclays of coal (abstract): Geol. Soc. America, Bull., vol. 24, no. 4, p. 719, December 23, 1913.

White, I. C.

1275. Petroleum fields of northeastern Mexico between the Tamesi and 'Tuxpan rivers: Geol. Soc. America, Bull., vol. 24, no. 2, pp. 253274, 2 pls., June 10, 1.913.

1276. Note on a very deep well near McDonald, Pennsylvania: Geol. Soc. America, Bull., vol. 24, no. 2, pp. 275-282, June 10, 1913.

1277. Petroleum fields of northeastern Mexico between the Tamesi and 'I"uxpan rivers (discussion by F. W. De Wolf) : Geol. Soc. America, Bull., vol. 24, no. 4, p. 706, December 23, 1913.

See also Cushing, no. 273.

Whitlock, H. P.

1278. The Mount Morris meteorite: New York State Mus., Bull. 164, pp. 78-79, 2 figs., 1.913.

Whitman, Alfred $\mathbf{R}$.

1279. The vadose synthesis of pyrite: Econ, Geology, rol. s, no. 5, pp. 455468. 1 fig., 1913; Min. and Sci. Press, vol. 107, p. 928, December 13, 1913 . 
Whitney, Milton, and others.

1280. Field operations of the Bureau of Soils, 1910. U. S: Dept. Agr., Bur. Soils, Twelfth Report. 1772 pp., 29 pls., 52 figs., and 43 soil maps (in separate case). Washington, 1912.

Contains soll surveys of the following areas:

Alabama, Dale County, pp. 605-639.

Pike County, pp. 641-703.

Callfornia, Livermore area, pp. 1657-1716. Madera area, pp. 1717-1753.

Red Bluff area, pp. 1601-1658.

Colorado, Uncompahgre Valley area, pp. 1443-1489.

Florida; Jacksonville area, pp. 583-604.

Georgia, Bullock County, pp. 45:-500.

Sumter County, pp. 501-543.

Walker County, pp. 545-582.

Kansas, western, pp. 1345-1442.

Kentucky, Rockcastle County, pp. 1017-1.048.

Louisiana, Concordia Parish, pp. 827-857.

Mississippi, Adams County, pp. 705-732.

Lauderdale County, pp. 733-784.

Noxubee County, pp. 785-826.

Missouri, Cape Girardeau County, pp. 1217-1260.

Jackson County, pp. 1261-1293.

Marion County, pp. 1295-1316.

Pemiscot County, pp. 1317-1344.

New York, Monroe County, pp. 43-91.

Ontario County, pp. 93-143.

North Carolina, Cabarrus County, pp. 297-339.

Granville County, pp. 341-380.

Mecklenburg County, pp. 381-418.

Pennsylvania, Erie County, pp. 145-192.

south central, pp. 193-265.

Washington County, pp. 267-296.

South Carolina, Clarendon County, pp. 419-451.

Texas, central Gulf coast area, pp. 859-929.

Ellis County, pp. 931-960.

Panhandle region, pp. 961-1015.

Washington, western Puget Sound basin, pp. 1491-1600.

West Virginia, Clarksburg area, pp. 1049-1.076.

Point Pleasant area, pp. 1077-1122.

Wisconsin, Bayfield area, pp. 1123-1146.

Iowa County, pp. 1147-1171.

Waukesha County, pp. 1173-1216.

Wickham, H. F:

1281. Fossil Coleoptera from the Wilson ranch near Florissant, Colorado: Iowa, State Univ., Bull. Lab. Nat. Hist., vol. 6, no. 4, pp. 3-29, 7 pls., April 26, 1.913.

1282. Fossil Coleoptera from Florissant in the United States National Museum: U. S. Nat. Mus., Proc., vol. 45, pp. 283-303, 5 pls., June 13, 1913.

Wieland, G. R.

1283. The Liassic flora of the Mixteca Alta of Mexico: Am. Jour. Sci., 4th ser., vol. 36, pp. 251-281, 2 figs. (including map), September, 1.913.

1284. La flora fôsil de la Mixteca Alta (abstract) : Soc. Geol. Mexicana, Bol., t. 8, pt. 1, p. viii, 1912.

Willey, Day Allen.

1285. The world's greatest iron ore deposits: Tng. Mag., vol. 44, no. 6, pp. 867-883, 15 figs., March, 1913.

Gives data regarding the iron-ore deposits of Cuba.

Williams, Edward H., jr.

1286. Alleghany Valley erosion: Science, new ser., vol. 37, pp. 44i-450, March 21, 1913. 
Williams, F. E.

1287. The petrified forests of Arizona: Jour. Geography, vol. 11, pp. 329-332, 5 figs., June, 1913.

A manual of physical geography excursions. See Martin, Williams, and Bean, no. 762 .

Williams, Henry Shaler.

1288. Recurrent Tropidoleptus zones of the upper Devonian in New York: U. S. Geol. Survey, Prof. Paper 79, 103 pp., 6 pls., 18 figs., 1913.

1289. New species of Silurian fossils from the Edmunds and Pembroke formations of Washington County, Maine: U. S. Nat. Mus.; Proc., vol. 45, pp. 319-352, 3 pls., 1913.

1290. Correlation problems suggested by a study of the faunas of the Eastport quadrangle, Maine: Geol. Soc. America, Bull., vol. 24; no. 3, pp. 377-398, September, 1913.

Geology of the Eastport quadrangle. See Bastin and Williams, no. 56.

Williams, M. G.

1291. Revision of the Silurian of southwestern Ontario: Ottawa Naturalist, vol. 27, pp. 37-38, June-July, 1913.

Williams, Merton $\mathrm{Y}$.

1292. The Hamilton formation at Thedford and vicinity [Ontario]: Intern. Geol. Cong., Twelfth, Guide Book no. 4 (issued by the Canada Geol. Survey), pp. 101-110, map, pls., 1913.

1293. The Silurian of the eastern part of Manitoulin Island: Intern. Geol. Cong., Twelfth, Guide Book no. 5 (issued by the Canada Geol. Survey), pp. 89-98, 1 map, 1 pl., 1 fig., 1913.

Willis, Bailey.

1294. Index to the stratigraphy of North America; accompanied by a geologic map of North America, compiled by Bailey Willis and G. W. Stose (abstract) : Washington Acad. Sci., Jour., vol. 3, no. 4, pp. 118-11.9, February 19, 1913.

Williston, S. W.

1295. Ostodolepis brevispinatus, a new reptile from the Permian of Texas: Jour. Geology, vol. 21, no. 4, pp. 363-366, 2 figs., 1913.

1296. The primitive structure of the mandible in amphibians and reptiles: Jour. Geology, vol. 21, no. 7, pp. 625-627, 1 fig., October-November, 1913.

1297. The skulls of Araeoscelis and Casea, Permian reptiles : Jour. Geology, vol. 21, no. 8 , pp. 743-747, 3 figs., November-December, 1913.

1298. The pelycosaurian mandible: Science, new ser., vol. 38, p. 512, October 10, 1913.

1299. An ancestral lizard from the Permian of Texas: Science, new ser., vol. 3s, pp. S25-826, December 5, 1913.

Permo-Carboniferous vertebrates from New Mexico. See Case, Williston, and Mehl, no. 185.

Williston, S. W., and Moodie, Roy L.

1300. New plesiosaurian genus from the Niobrara Cretaceous of Nebraska (abstract) : Geol. Soc. America, Bull., vol. 24, no. 1, pp. 120-121, March 24, 1913.

Wilson, Alfred W. G.

1301. Report on mineral deposits in the vicinity of St. Mary Bay, Nova Scotia: Canada, Dept. Mines, Mines Branch, Summ. Rept. 1912, pp. 81-83, 1913. 
Wilson, Alice $\mathrm{E}$.

1302. A new brachiopod from the base of the Utica: Canada Geol. Survey, Victoria Memorial Mus., Bull. no. 1, pp. 81-84, 1 pl., October 23, 1913.

Describes Oxoplecia calhouni n. gen. and n. sp. from the Utica of Ottawa, Ontario.

Wilson, Morley E.

1303. 'The Cobalt series; its character and origin: Jour. Geology, vol. 21, no. 2, pp. 121-141, 3 figs., February-March, 1913.

1304. The significance of recent developments in the pre-Cambrian stratigraphy of the Lake Superior-Lake Huron region: Jour. Geology, vol. 21, no. 5. pp. 385-398, 1913.

1305. The banded gneisses of the Laurentian highlands of Canada: Am. Jour. Sci., 4th ser., vol. 36, pp. 109-122, August, 1913.

Describes the lithologic character, geologic relations, and structural features of the rocks, and discusses their origin.

Winnipeg to Cochrane via National Transcontinental Railway. See Collins and Wilson, no. 249.

Wilson, W. J.

1306. A new genus of dicotyledonous plant from the Tertiary of Kettle River, British Columbia : Canada Geol. Survey, Victoria Memorial Mus., Bull. no. 1, pp. 87-88, 1 pl., October 23, 1913.

1307. A new species of Lepidostrobus: Canada Geol. Survey, Victoria Memorial Mus., Bull. no. 1, pp. 89-92, 1 pl., October 23, 191.3.

Winchell, Alexander N.

1308. Rock classification on three co-ordinates: Jour. Geology, vol. 21, no. 3, pp. 208-223, 3 tables, 1913; (abstract), Science, new ser., vol. 37, p. 460, March 21, 1913.

See also Spurr, no. 1097.

Winchell, Horace V.

1309. Persistence of ore deposits in depth: Min. and Sci. Press, vol. 107, pp. 332-334, August 30, 1913.

The St. Helens mining district [Washington]: Am. Inst. Min. Jeng., 'Trans., vol. 44, pp. 580-587, 1 fig. (sketch map), 1913. See no. 1226 of the bibliography for 1912, U. S. Geol. Survey, Bull. 545.

See also Graton and Murdoch, no. 437.

Winchell, Newton $\mathrm{H}$.

1310. The iron ore ranges of Minnesota, and their differences: Minnesota Acad. Sci., Bull., vol. 5, no. 1, pp. 43-68, 24 figs., 1911.

1311. The weathering of aboriginal stone artifacts, no. 1 ; a consideration of the paleoliths of Kansas: Minnesota Hist. Soc., Coll., vol. 16, pt. 1, xiv, 186 pp., illus., 1913.

1312. The age of the Mesabi iron-bearing rocks of Minnesota (abstract) : Science, new ser., vol. 37, p. 457, March 21, 1913.

Winchester, Dean E.

1313. Cross-bedding in the White River formation of northwestern South Dakota: Jour. Geology, vol. 21, no. 6, pp. 550-556, 5 figs. (including map), September-October, 1913.

Winslow, A. See Emmons, no. 355 .

Winsted, Huldah ' $\mathrm{L}$ :'

1314. The seat caves at La Jolla, California: Jour. Geography, vol. 12, no, 4, pp. 125-126, 2 figs., December, 1913. 
Wittich, Ernesto.

1315. Observaciones sobre el postplioceno á lo largo de los ríos Papaloapam, Tezechoacan y Manso: Soc. Geol. Mexicana, Bol., t. 8, pt. 1, pp. ix, 41-46, 2 figs., 1912.

1316. Estudio de algunos minerales raros del Estado de Chihuahua: Soc. Geol. Mexicana, Bol., t. 8, pt. 1, pp. ix-x, 47-51, 1912.

Describes some rare minerals from the State of Chibuahua, Mexico. Informe relativo á la exploración de la región Norte de la costa occidental de la Baja California. See Böse and Wittich, no. 86.

Wittich, Ernesto, and Pastor y Giraud, Antonio.

1317. Reseña acerca de los topacios de México: Soc. Geol. Mexicana, Bol.,

t. $S$, pt. 1, pp. x-xi, 53-59, 1912.

An account of the topazes of Mexico.

1318. Unos cristales gigantes de yeso, procedentes de la mina Naica, Chihuahua: Soc. Geol. Mexicana, Bol., t. 8, pt. 1, pp. xi-xii, 61-70, 1 pl., 1912.

Describes giant crystals of gypsum from Naica, State of Chihuahua, Mexico.

Wolf, J. H. G.

1319. The Mother Lode of California : Min. and Sci. Press, vol. 106, pp. 934938, 983-986, 9 figs., June 21 and 28, 1913.

Gives notes on the geology and structural relations and on the

Wood, Harry O. character of the ore bodies.

1320. The Hawaiian volcano observatory: Seism. Soc. America, Bull., vol. 3, no. 1, pp. 14-19, March, 1913.

Wood, Robert H.

1321. Oil and gas development in north-central Oklahoma: U. S. Geol. Survey, Bull. 531, pp. 27-53, 1 pl. (map), 1913.

Woodman, J. Edmund.

1322. Forelands of the Bras d'Or Lakes, Cape Breton Island, Nova Scotia (abstract) : New York Acad. Sci., Annals, vol. 22, p. 351, April $20,1913$.

1323. The interbedded iron ores of Nova Scotia (abstract, with discussion by J. F. Kemp and G. Van Ingen) : Science, new ser., vol. 38, p. 281, August 22, 1913.

Woodruff, E. G,

1324. Measurement of the thickness of strata with the plane table and telescopic alidade : Econ. Geology, vol. 8, no. 3, pp. 291-297, 2 figs., 1913.

1325. Geology and petroleum resources of the De Beque oil field, Colorado: U. S. Geol. Survey, Bull. 531, pp. 54-68, 1 pl. (map), 1 fig., 1913.

1326. Cone in cone structure in coal from St. Anthony, Idaho (abstract) : Washington Acad. Sci., Jour., vol. 3, no. 8, p. 237, April 19, 1913.

Woodward, Arthur Smith.

1327. On a new specimen of the Cretaceous fish Porthens molossus, Cope [from Kansas]: Geol. Mag., new ser., dec. 5, vol. 10, no. 12, pp. 529-531, $1 \mathrm{pl}$., December, 1913.

Woodworth, J. B.

1328. Harvard seismographic station; fourth annual report for the year 1 August, 1911-31 July, 1912: Harvard Coll., Mus. Comp. Zool., Bull., vol. 55, no. 2 (Geol. ser., vol. 9, no. 2), pp. 27-51, February, 1913.

1329. Memoir of Ralph Stockman Tarr: Geol. Soc. America, Bull., vol. 24, no. 1, pp. 29-43, 1 pl. (port.), March 24, 1913.

Includes a list of his writings. 
Woodworth, J. B.-Continued.

1330. Dynamical and structural geology : Am. Year Book, 1912, pp. 605-607,

New York, 1913.

See also Goldthwait, no. 415.

Woodworth, J. B., and others.

1331. "The pre-Cambrian nomenclature": Econ. Geology, vol. 8, no. 3, p. $309,1913$.

Woolsey, W. J.

1332. Notes on asbestos veins and the mineral nephrite: Canadian Min. Jour., vol. 34, p. 519, 2 figs., August 15, 191.3.

Worcester, P. G.

Reconnaissance of the geology of the Rabbit Litrs region, Routt, Grand, and Jackson counties [Colorado]: See Grout, Worcester, and Henderson, no. 450.

Wright, Clarence A.

1333. Mining and treatment of lead and yinc ores in the Joplin district, Missouri; a preliminary report: U. S. Bur. Mines, Tech. Paper 41, 43 pp., 5 figs., 1913.

Wright, Fred. Engene.

1334. Oblique illumination in petrographic microscope work: Am. Jour. . Sci., 4th ser., vol. 35், pp. 63-82, 18 figs., January, 1913.

1335. The index ellipsoid (optical indicatrix) in petrographic microscope work: Am. Jour. Sci., 4th ser., vol. 35, pp. 133-138, February, 1913; (abstract), Washington Acad. Sci., Jour., vol. 3, no. 20, p. 503, December 4, 1913; (abstract and discussion by E. B. Mathews), Geol. Soc. America, Bull., vol. 24, no. 4, pp. 681-682, December $23,1913$.

1336. Mikroskopische Petrographie vom quantitativen Gesichtspunkte aus: Neus Jahrb., Beilage Bd. 35, pp. 735-775, 1913; (abstract), Washington Acad. Sci., Jour., vol. 3, no. 4, p. 115, February 19, 1913.

Discusses microscopic petrography from the quantitative standpoint.

1337. A new thermal microscope for the measurement of the aptical constants of minerals at high temperature: Washington Acad. Sci., Jour., vol. 3, no. 8, pp. 232-236, 3 figs., April 19, 1913.

1338. Yukon and Malaspina, Prince Rupert-Skagway section: Intern. Geol. Cong., Twelfth, Guide Book no. 10 (issued by the Canada Geol. Survey), pp. 41-51, maps, 1913.

1339. Graphical methods in microscopical petrography: Am. Jour. Sci., 4th ser., vol. 36 , pp. 509-539, 8 pls., 9 figs., November, 1913.

1340. A graphical plot for use in the microscopical determination of the plagioclase feldspars: Am. Jour. Sci., 4th ser., vol. 36, pp. 540-542, $1 \mathrm{pl} .$, November, 1913.

1341. The change in the crystal angles of quartz with rise in temperature: Washington Acad. Sci., Jour., vol. 3, no. 20, pp. 4S5-494, 2 figs., December 4, 1913.

1342. Experimental geology, one of the large subdivisions of geology (abstract, with discussion by A. W. Grabau) : Geol. Soc. America, Bull., vol. 24, no. 4, pp. 671-672, December 23, 1913.

Calcium vanadates from. Peru, Colorado, and Utah. See Hillebrand, Wright, and Merwin, no. 505.

Wright, Fred E., and Van Orstrand, C. E.

1343. The determination of the order of agreement between observation and theory in nineral analyses: Washington Acid. Sci., Jour., vol. 3, no. 8, pp. 223-231, April 19, 1913. 
Wright, G. Frederick.

1344. Work of natural forces in relation to time: Nature, vol. 92 , p. 346, November 20, 1913.

1345. Recent date of the attenuated glacial border in Pennsylvania: Intern. Geol. Cong., Twelfth, Canada, 3 pp., 1 map, 1913 (advance copy).

Yale, Charles G., and Gale, Hoyt S.

1346. Borax; magnesite: U. S. Geol. Survey, Mineral Resources, 1912, pt. 2, pp. 839-\$46, 1 map, 1071-1077, 1913.

Young, G. A.

1347. Excursion in eastern Quebec and the maritime provinces; geology (pp. 11-16) ; Rivière du Loup (pp. 56-66) ; Bic (pp. 69-77) ; Bathurst mines (pp. 125-129); the Riversdale-Union group at Truro and in the type section along the intercolonial railway east of Truro, introduction (pp. 215-220); the New Glasgow conglomerate (pp. 229-240) ; Sydney coalfield, introduction (pp. 242-249); George River (pp. 266-276) ; Moncton-Albert mines (pp. 351-363); St. John and vicinity (pp. 369-390); Grand Falls, St. John River (pp. 399-405) ; and annotated guide: Intern. Geol. Cong., Twelfth, Guide Book no. 1 (issued by the Canada Geol. Survey), maps, 1913.

Young, G. A., and others.

1348. Excursion in eastern Quebec and the maritime provinces: Intern. Geol. Cong., Twelfth, Guide Book no. 1 (issued by the Canada Geol. Survey), 2 pts., pp. 1-207, 209-407, pls., figs., and maps, 1913.

Youngs, L. J.

Some interesting changes in the optical properties of crystals with temperature (abstract). See Kraus and Youngs, no. 639.

Zalinski, Edward R.

1349. Ore occurrence at Prince Consolidated [mine, Pioche, Nev.]: Eng. and Min. Jour., vol. 95, no. 16, pp. 809-\$12, 7 figs., April 19, 1913.

1350. Occurrence of oxidized zinc ores at Tintic [Utah]: Eng. and Min. Jour., vol. 95, no. 25, pp. 1227-1228, 2 figs., June 21, 1913.

Zapffe, Carl, and Barrows, W. A., jr.

1351. The iron ores of the South Range of the Cuyuna district, Minnesota : Am. Inst. Min. Eng., Bull. no. 74, pp. 215-225, February, 1913; Trans., vol. 44, pp. 3-13, 1913.

Ziegler, Victor.

1352. The order of crystallization in igneous rocks: Jour. Geology, vol. 21, no. 2, pp. 181-185, February-March, 1913.

1353. Lithia deposits of the Black Hills: Eng. and Min. Jour., vol. 96, pp. 1053-1056, 4 figs., December 6, 1913.

Anonymous.

1354. Mastodon remains: Tennessee State Geol. Survey, The Resources of Tennessee, vol. 3, no. 2, p. 110, April, 1913.

Describes the finding of Mastodon remains near Nashville, Tenn.

1355. The Twelfth International Geological Congress: Canadian Min. Jour., vol. 34, pp. 455-472, 504-517, 60 figs., August 1 and 15, 1913.

1356. Prospecting for potash in Death Valley, California: Min. and Eng. World, vol. 38, pp. \$55-\$56, May 3, 1913. Translated by G. Bentz in Zeitschr. prakt. Geologie, Jg. 21, pp. 419-422, September, 1913.

1357. The Cape Breton, Nova Şcotia, coal fields: Coal Age, vol. 4, no. 22, pp. 805-806, 2 maps, November 29, 1913. 


\section{CLASSIFIED SCHEME OF SUBJECT HEADINGS.}

\section{GENERAI.}

Associations, meetings; Addresses; History; Philosophy; Biography ; Bibliography ; Educational; Text-books.

Classification ; Nomenclature; Cartography ; Technique; Field work ; Surveys ; Borings.

Geochemistry; Chemical analyses (list); Atmosphere; Raldioactivity.

Experimental investigations; Miscellaneous.

\section{REGIONAL.}

The States of the Union, Alabama, etc.; the Provinces of Canada, Alberta, etc.; Greenland; Mexico; the countries of Central America; the West Indies, and the single islands; the Hawaiian Islands.

\section{ECONOMIC.}

Ore deposits, origin; Contact phenomena.

Gold; Placers; Black sands; Silver; Quicksilver; Nickel; Cobalt; Copper; Lead; Zinc; Iron; Magnetite; Manganese; Tin; Aluminum; Bauxite; Antimony ; Bismuth; Tungsten; Wolframite; Vanadium; Uranium; Carnotite ores ; Molybdenum; Molybdenite; Titanium; Rutile; Platinum; Iridium; Rhodium; Palladium; Cadmium; Monazite; Rare earths; Tantalum; Selenium; Tellurium; Zircon.

Coal; Anthracite; Coke; Peat; Lignite; Bituminous rock; Natural gas; Petroleum; Oil shales; Asphalt; Albertite; Gilsonite; Grahamite; Ozokerite.

Stone; Building stone; Granite; Bluestone; Limestone ; Lime; Marble ; Onyx ; Sandstone; Clay; Kaolin; Bentonite; Fire clay ; Ganister ; Slate; Shale; Marl; Sand; Glass sand; Sand-lime brick; Gravel; Cement and cement materials; Concrete materials; Road materials; Trap; Steatite; Soapstone; Talc; Serpentine.

Precious stones; Diamonds; Sapphires; 'Iurquoise; T'ourmaline.

Abrasive materials; Corundum; Emery; Garnet; Diatomaceous earth ; 'Tripoli; Volcanic ash; Millstones; Novaculite.

Asbestos; Feldspar; Mica ; Quartz; Gypsum ; Graphite; Fuller's earth ; Infusorial earth; Magnesite; Mineral paint; Chromium; Chromite; Chromic iron ore; Fluorspar; Barite; Barytes; Strontium ; Arsenic; Pyrite; Sulphur; Sul. phate of soda; Cryolite; Phosphorus; Phosphate; Apatite; Potash; Alunite; Glauconite; Borax; Bromine; Salt; Natron deposits.

\section{DYNAMIC AND STRUCTURAL.}

Earth, genesis of ; Earth, age of ; Earth, interior of ; Earth, temperature of.

Volcanism; Volcanoes; Earthquakes; Seismology ; Seismographs; Mud volcanoes.

Isostasy; Orogeny; Changes of level.

$38416^{\circ}-$ Bull. $584-14-8$ 
Magmas; Intrusions; Dikes ; Laccoliths; Metamorphism ; Contact phenomena. Deformation; Folding; Faulting; Unconformities.

Conglomerates; Concretions; Stalactites; Jointing; Cleavage.

Sedimentation; Denudation; Erosion; Caves; Sink holes; Erratic bowlders; Weathering; Wind work; Dunes; Loess; Landslides.

Glaciers; Glacial erosion; Eskers; Kames; Moraines; Kettle holes.

Drainage changes.

\section{PHYSIOGRAPHIC.}

Geomorphy ; Relief maps.

Valleys; Cirques; Deserts; Dunes; Deltas; Alluvial fans; Eskers; Kames; Mounds, natural; Natural bridges; Sink holes; Karsts.

Lakes; Swamps; Marshes; Everglades; 'Terraces; Beaches; Shore lines; Rivers; Meanders; Falls; Springs.

\section{HISTORIC OR STRATIGRAPHIC.}

Geologic history; Geologic time; Paleogeography; Paleogeographic maps; Paleoclimatology.

Geologic maps; Geologic formations described (list).

Pre-Cambrian; Paleozoic (undifferentiated) ; Cambrian; Ordovician; Silurian; Devonian; Carboniferous; Triassic; Jurassic; Cretaceous; Tertiary; Quaternary; Recent; Glacial geology; Glaciation; Glacial lakes; Ice ages.

\section{PALEONTOLOGY.}

Geographic distribution; Evolution; Restorations.

Vertebrata ; Man, fossil ; Mammalia ; Aves; Reptilia ; Amphibia ; Pisces ; Footprints, fossil.

Invertebrata; Arthropoda ; Crustacea ; Trilobita ; Ostracoda ; Insecta ; Arachnida; Myriapoda.

Mollusca; Cephalopoda ; Gastropoda ; Pelecypoda.

Molluscoidea; Brachiopoda; Bryozoa; Vermes.

Echinodermata ; Echinoidea; Asteroidea; Crinoidea; Crystoidea.

Ooelenterata; Anthozoa; Hydrozoa; Graptolites.

Protozoa; Spongida; Foraminifera.

Paleobotany; Diatoms.

Problematicil.

\section{PETROLOGY.}

Rocks, origin; Rocks, structural features; Rocks described (list); Igneous and volcanic rocks; Rock-forming minerals; Lava; Oolite; Pebbles.

\section{MINERALOGY}

Minerals described (1ist); Crystallography; Pseudomorphism; Paragenesis of minerals; Rock-forming minerals; Meteorites.

\section{UNDERGROUND WATER.}

Mine waters; 'Thermal waters; Geysers; Springs; Mineral waters.

11. soILs. 


\section{INDEX.}

[The numbers refer to entries in the bibllography.]

Abrasive materials.

United States: Katz, 580.

Addresses.

Genetic theories of ore deposits, application to search for local enrichments: Collins, 243.

Geology : Marbut, 744 .

Glacier's and glaciation of Alaska : Tarr, 1145.

Influence of applied geology : Van Hise, 1207.

Pleistocene geology, New Iork: l'ailchild, 366 .

Pleistocene mollusks, significance: Shimek, 1044.

Variations in Upper Cretaceous stratigraphy: Stanton, 1101.

Alabama.

Economic.

Mineral production, 1911: Abele, 3.

Paleontology.

Tuscaloosa flora: Berry, 72 .

Zeuglodon: Gidley, 403 .

Alaska.

General.

Seward Peninsula: Smith, 1070.

Yentna district: Capps, 177.

Economic.

Big Bonanza copper deposits : 'Thompson, 1157.

Chisana district: Cairnes, 162.

Chitina Valley, copper and gold deposits : Moffit, 828 .

Circle quadrangle: Prindle, 930.

Coal, Bering River field: Crane, 260263.

Matanuska field: Crane, 264, 265.

Coal resources: Brooks and Martin, 110.

Ellamar district: Capps and Johnson, 178.

Fairbanks district, gold lodes: Smith, 1069.

Fairbanks quadrangle: Prindle, 929.

Gold, fineness in Fairbanks district: Smith, 1.073.

Grand Central quadrangle : Moffit, 827.

Innoko-Iditarod region, gold placers: Eakin, 337.
Alaska-Continued.

Economic-Continued.

Kodiak and neighboring islands: Martin, 750 .

Koyukuk-Chandalar region: Maddren, 739.

McKinley Lake district: Chapin, 196. Marble resources, Ketchikan and Wrangell districts: Burchard, 134.

Mineral resources, 1912 : Brooks et $a l$., 1.09.

Mining Industry, 1912 : Brooks, 108.

Noatak-Kobuk region: Smith, 1068.

Nome quadrangle: Moffit, 827.

Rampart quadrangle: Eakin, 335.

Ruby district, gold placer's : Eakin, 336 .

Willow Creek district, gold lodes: Smith, 1074.

Yentna district: Capps, $\mathbf{1 7 7}$.

Yukon-Ianana reglon, placer gold: Ellsworth and Davenport, 347 .

Dynamic and structurat.

Allen glacier: Martin, 758 .

Coastal glaciers, Frince William Sound and Kenal Feninsula: Grant and Higgins, 434 .

Glaciers, Prince William Sound: Martin, 759 .

variations: Reid, 962-964.

Katmal Volcano: Abbot and lowle, 2; Martin, 751.

Physiographic.

Arctlc slope: Leffingwell, 673.

Coastal glaciers, Prince William sound and Kenai Peniusula: Grant: and Higgins, 434.

Copper River Basin: 'Tarr and Martin, 1146.

Copper River canyon and deltas: Martin, 761 .

Glaciers: Martin, 760.

Kenai Peninsula : Tarr and Martin, 1147.

Glaciers and glaciation: Tarr, 1145 .

Tuneau-Yakutat section: Martin, 754.

Noatak River: Smith, 1.071.

Prince Rupert to Skigway: Wright, 1338.

Prince William Sound: Martin, 759.

Quaternary problems: Eakin, 335. 
Alaska-Continued.

Stratigraphic.

Arctic slope: Leffingwell, 673.

Circle quadrangle: Prindle, 930.

Copper River basin, glacial deposits: Tarr and Martin, 1146.

Fairbanks quadrangle: Priudle, 929.

Grand Central quadrangle: Moffit, 827.

Koyukuk-Chandalar region: Maddren, 739.

Noatak-Kobuk region: Smith, 1068.

Nome quadrangle: Moffit, 827.

Prince Rupert to Skagway: Wright, 1338.

Rampart quadrangle : Eakin, 335.

Yentna district: Capps, 177.

Yukon-Alaska boundary: Cairnes, 161. Paleontology.

Cretaceous and Tertiary floras: Hollick, 516 .

Equus, skull : Hay, 472.

Petrology.

Circle quadrangle: Mertie, 802.

\section{Alberta.}

General: Bryce, 131.

Stratigraphic.

General: Collins and Camsell, 248; Dowling, 326 ; Malcolm, 741.

Calgary to Tofield: Dowling, 327.

Coal fields: Leach, 666.

Dunmore to Burmis: Dowling, 327.

Edmonton area : MacLean, 736 .

Fleistocene deposits: Alden and Stebinger, 11.

Robson Peak district: Walcott, 1225.

Rocky Mountains: Allan, 13.

Tofield to Tete Jaune: Dowling, 327.

Paleontology.

Cambrian, Robson Peak region: Walcott, 1224.

Ceratopsia, Styracosaurus: Lambe, 651.

Dinosaur: Brown, 117.

Helodont teeth, Roche Miette: Lambe, 648.

Hypacrosaurus, Edmonton Cretaceous : Brown, 120.

Leurospondylus, Edmonton Cretaceous : Brown, 124.

Saurolophus, Edmonton Cretalceous: Brown, 119.

Spiriferoids, Lake Minnewanka section : Shimer, 1045.

Trachodon from Edmonton formation : Lambe, 649.

Algonkian. See Pre-Cambrian.

\section{Alluvial fans.}

General: Grabau, 427 ; Lawson, 662.

\section{Aluminum.}

General: Phalen, 917.

United States: Phalen, 916.

Alunite.

Arizona, Patagonia : Schrader, 1022.

Colorado, San Cristobal quadrangle: Larsen, 658.

Nevada, Bovard : Schrader, 1022.
Ammonites. See Cephalopoda.

Amphibia.

Crossopterygian ancestry: Gregory, 445.

Mandible, primitive structure: Williston, 1296.

New Mexico, Permo-Carboniferous : Case et al., 185.

Pennsylvanian, Illinois, Mazon Creek: Moodie, 831.

Skull elements, Permian Tetrapoda: Huene, 539 .

Stegocephala, Permian, Tex.: Broili, 104.

Stegocephalians: Broom, 114.

Analyses, chemical. See list, p. $16 \%$.

Angistorhinus: Mehl, 784.

Animikie. See Pre-Cambrian.

Antimony.

General: Hess, 488 .

British Columbia, Atlin district: Cairnes, 158.

United States: Hess, 488.

Apatite.

Quebec, Emerald mine: Stansfield, 1101.

Virginia: Watson and Taber, 1247.

Appalachians, newer and older: Emerson, 350.

Arachnida.

Paleozoic, ter'estrial: Petrunkevitch, 911.

Archean. See Pre-Cambrian.

Arctic regions.

Stratigraphic.

Ellesmere Land, Cambro-Ordovician beds of Bache Peninsula : Holtedahl, 518.

Puleontology.

Ellesmere Land, Devonian Brachiopoda: Meyer, 807.

\section{Arizona.}

General.

Canyon Diablo irons: Keys, 613.

Fossil forest: Merrill, 800.

Economic.

Alunite, Patagonia: Schrader, 1022.

Bisbee deposits : Notman, 853.

Copper deposits : Ransome, 945.

in porphyries: Weed, 1257.

Gold placers: Carter, 182.

Oro Blanco district: Milton, 823.

Silver at Globe: Tovote, 1168.

Tonto Basin oil district: Botsford, 88 .

Turquoise copper district: Ransome, 946.

Dynamic and structural.

Grand Canyon, angular amphitheaters :

Keyes, 607.

Physiographic.

Bajadas, Tucson bolson: Visher, 1216.

Graud Canyon: Davis, 296. 
Arizona-Continued.

Physiographic-Continued.

Meteor Crater: Margerie, $\mathbf{7 4 6}$; Niermeyer, 849 .

Petrified forests: Williams, 1287.

San Franciscan volcanic field: Robinson, 987 .

Sulphur Spring Valley: Meinzer and Kelton, 785 .

Stratigraphic.

San Franciscan volcanic field: Robinson, 987.

Shinarump conglomerate: Gregory, 440.

Sulphur Spring Valley: Meinzer and Kelton, 785 .

Turquoise copper district: Ransome, 946 .

raleontology.

Fossil forests: Innowlton, 684.

Petrology.

Magmatic differentiation, Silverbell : Stewart, 1.1.13.

San Franciscan volcanic field: Robinson, 987.

Mineralogy.

Cerusite twin, Mammoth mine, Pinal County: Pogue, 922.

Cuprodescloizite, Bisbee: Wells, 1263.

Delafossite from Bisbee: Rogers, 989.

Underground water.

Sulphur Spring Valley: Meinzer and Kelton, 785 .

\section{Arkansas.}

Economic.

Fuller's earth: Miser, 826.

Zinc deposits, Boone and Marion counties: Thomas, 1156.

Arsenic.

United States: Hess, 489.

Artesian waters and wells. See Underground water.

Arthropoda. See also Arachnida; Crustacen : Insecta.

Devonian, Illinois: Savage, 1009.

\section{Arthrodira.}

Kentucky, Devonian : Hussakof, 542.

Articulata.

Paleozoic Arachnida, scorpions and spiders: Petrunkevitch, 912.

Asbestos.

Nephrite in asbestos veins: Woolsey, 1332

Quebec: Harvie, 466.

United States: Diller, 321.

Asphalt. See also Grahamite.

Oklahoma : Snider, 1079, 1080.

United States: Day, 303.

Utah : Riter, 983.

Associations, meetings.

American Association Advancement Science, Section E, 1912-13: Kay, 581.
Associations, meetings-Continued.

Geological Society America, proceedings twenty-fifth meeting, 1912: Hovey, 528.

abstracts of papers: Hovey, 529.

Cordilleran section, proceedings thirteenth meeting, 1.912: Touderback, 704.

International Geological Congress, Twelfth : Hobson, 511, Penrose, 901 ; W., 1218; Anonymous, 1355.

Paleontological Society, proceedings fourth meeting, 1912: Bassler, 50.

Pacific Coast section, third meeting, 1912 : Dickerson, 315.

\section{Asteroidea.}

Onychaster, Crawfordsville, Indianu: Sollas, 1.082.

Protopalæaster narrawayi: Fudson, 536.

Stereograms: Hudson, 535.

Aves.

Fossil birds: Shufeldt, 1.051.

Fossil feathers: Shufeldt, 1052.

Meleagridæ: Shufeldt, 1047.

Oregon: Shufeldt, 1050.

Ostrich : Shufeldt, 1.049.

Pacific Coast: Miller, 812.

P'leistocene avifauna, Oregon : Shufeldt, 1048.

Bahama Islands.

General: Vaughan, 121.0-1212.

Bajadas, Tucson bolson: Visher, 1216.

Barbados.

Economic.

Oilfields: Cunningham-Craig, 270.

Barnesboro quadrangle, Pennsylvania: Campbell et al., 169.

Barytes. See also Barite.

United States: Hill, 501.

Rathyliths. See Intrusions.

Bathyopsis, Wind River uintathere: Osborn, 865 .

Batrachia. See Amphibia.

Bauxite.

General: Phalen, 917.

Tennessee, dilizabethtown: Watkins, 1238.

United States: Phalen, 916.

Feaches. See Shore lines; Terraces.

Bermuda Islands.

General: Peile, 897.

Boring: Pirsson and Vaughan, 921.

Bibliography.

Aluminum : Phalen, 916.

Barytes: HIll, 501.

Bauxite: Phalen, 916.

Buckley, E. R., writings : Buehler, 133.

Canada, 1908-1.911: Reinecke, 968.

Cement materials: Eckel, 342.

Colorado, Permian: Butters, 153 
Bibliography-Continued.

Cyclocystoides: Raymond, 953.

Dutton, C. E., writings: Diller, 319.

Economic geology, recent literature : Knopf and Umpleby, 631 ; Paige and Lloyd, 873.

Iowa : Keyes, 601.

Jouns Hopkins University, Department of Geology : Mathews and Reed, 765.

McGee, W J, writings: Knowlton, 635. Maine: Babb, 21.

Maryland, Devonian: Prosser, 933.

Mazon Creek shales fauna: Moodie, 831 .

Mica : Sterrett, 1107.

Mineral paints: Hill, 501.

New Madrid earthquake: Sampson, 1003.

New York, pre-Cámbrian: Kemp, 588.

Niagara Falls : Haskell, 467.

North American geology, 1912 : Nickles, 848.

Ore genesis: Irving et al, 549.

Phosphates, Florida: Sellards, 1036.

Potholes: Barker, 40

Tarr, R. S., writings: Woodworth, 1329.

Utah, Wasatch Mountains: Hint\%e, 507.

Washington : O'Donnell, 855.

Bighorn dolomite, origin: Blackwelder, 78 .

Biography.

Buckley, E. R. : Buehler, 135.

Dana, T. D. : Clarke, 212 ; Hadley, 454 ; Hovey, 530; Merrill, 797; Rice, 970.

Dutton, C. E. : Diller, 319.

Fmmons, S. F.: Becker, 59

Hall, Christopher Webber: Martin, 755.

Hyatt, Alpheus: Jackson, 550.

Teidy, Toseph: Minot, 824.

McGee, W J: Keyes, 605; Knowlton, 635.

Miller. W. G. : Lamb, 647.

Tarr, R. S.: Woodworth, 1329.

Ward, L. F.: Hollick, 515.

Birds. See Aves.

Bismuth.

United States: Hess, 488.

Bivalves. See Pelecypoda.

Blowing wells. See Underground water.

Blue Hills, Massachusetts, petrology: Wárren, 1234

Bolosaurus: Broom, 112.

Borax.

United States: Yale and Gale, 1346.

Borings.

Alberta : Malcolm, 741.

Bermuda Island: Pirsson and Vaughan, 921.

California, Cat Canyon oil field: Smith, 1059.

Delaware: Matson, 766 .

Mexico, northeastern: White, 1275.

Michigan, Detroit: Fry, 391.

Manistee region : Fry, 390.
Borings-Continued.

Nevada, Silver Peak Marsh, Dole, 323.

Timber Lake: Gale, 393.

Ohio, Findlay: Condit, 252.

Oklahoma : Wood, 1321.

Pennsylvania, McDonald deep well : White, 1276

Rotany, fossil. See Paleobotany.

\section{Brachiopoda.}

Cambrian, Alberta: Walcott, 1224.

Devonian, Ellesmere Land: Meyer, 807.

Maine, Silurian : Williams, 1289.

Maryland, Devonian: Clarke and Swartz, 214; Prosser and Kindle, 935; Schuchert and Maynard, 1028.

Oxoplecia, Utica of Ontario: Wilson, 1302.

Spirifer mucronatus, modifications; Grabau, 428.

Spiriferoids, Lake Minnewanka section, Alberta : Shimer, 1045.

Breathing wells. Sec Underground water. Breccia. See Rock structures.

\section{British Columbia.}

General.

Coast Range: Porter, 923.

Fuman skeleton in silt at Savona : Moncton, 829 .

Economic.

Atlin district: Cairnes, $\mathbf{1 5 8 .}$

Atlin gold fields: Atlin district: Board of Trade, 20 .

Coal fields, Queen Charlotte Islands: Clapp, 201.

Vancouver Island: Clapp, 200

Coast region: Bancroft, 35 .

Fire clay deposits, Clayburn: Camsell, 171.

Granby Bay: McConnell, 719 .

Iynn Creek district: Emmens, 351.

Peace River canyon, coal measures: Galloway, 394.

Report, Bureau of Mines, 1912 : Robertson, 986.

Tulameen district: Camsell, 1.70

Physiographic.

Asulkan Glacier: Ries, 982.

Coast region: Bancroft, 35 .

Contraposed shorelines: Clapp, 198.

Interior plateaus, Savona to Iytton : Drysdale, 331.

Similkameen district: Camsell, 1.72.

Vancouver Island : Clapp, 199.

Stratigraphic.

Atlin district: Cairnes, 158.

Coal fields: Leach, 666.

Coast Range, columnar sections : Bowen, 93.

Coast Range, Lytton to Vancouver : Camsell, 171

Coast region: Bancroft, 35 .

Cordillera, forty-ninth parallel: Daly, $278,279$. 
British Columbia_Continued. stratigraphic-Con tinued.

Elko to Kootenay Lake: Schofield, 1020.

Granby Bay: McConnell, 719.

Interior plateaus, Savona to Lytton: Drysdale, 331.

reace River canyon, coal measures: Galloway, 394.

Robson Peak district: Walcott, 1225.

Rocky Mountains: Allan, 13.

Similkameen district: Camsell, 172.

Skeena River district: McConnell, 719.

Tulameen district: Camsell, 170.

Vancouver Island: Clapp, 199.

West Kootenay and Boundary districts: LeRoy, 680 .

Paleontology.

Cambrian fauna at Field: Walcott, 1227.

Kettle River region, fossil plants: Penhallow, 898.

Jebephyllum, Tertiary, Kettle River: Wilson, 1306.

\section{Petrology.}

Coast region: Bancroft, 35.

Cordillera, forty-ninth pirallel: Daly, 278.

T'ulameen district: : Camsell, 170.

West: Kootenay and Boundary districts: LeRoy, 680.

Bromine.

United States: Fhalen, 915.

Bryozoa.

Maryland, Devonian : Ulrich and Bassler, 1.190, 1.191.

Building stone. See also Granite; Limestone; Sandstone; Stone.

Quebec: Parks, 885.

Cadmium.

United States : Siebenthal, 1053.

\section{California.}

Economic.

Anticlinal dome structure in oil fields: Hager, 456.

Cat Canyon oil field: Smith, 1059.

Colemanite deposits, origin: Gale, 392.

Copper, Shasta County: Gilbert and Pogue, 405 ; Whitman, 1279.

Gold lodes, Carrville district, Irinity County: MacDonald, 722.

Lapis lazuli, southern California: Surr, 11.31.

Mother lode: Eddy, 346; Wolf, 1319.

Petroleum : Prutzman, 938.

Santa Susanna district: Johnson, 563.

Potash, Death Valley: Anon., 1356.

Pyrites deposit, Plumas County : Bradley, 96 .

Searles Lake potash deposit: Dolbear, 322.

Shasta County, copper deposits : Storms, 1125.

Woody district, Kern County, copper : Storms, 1126.
California-Continued.

Dynamic and structural.

Earthquake registration at Berkeley station, 1912: Davis, 290.

Oil-bearing rocks, accumulation : Branner, 98 .

Rancho La Brea deposits: Mattlew, 779 .

accumulation : Stoner, 1120

Sea caves at La Jolla: Winsted, 1314.

Travertine, origin, Salton Sink: Jones, 572.

Physiographic.

Russian River: Holway, 51.9.

Yosemite Valley, El Capitan moraine and ancient Lake Yosemite; Matthes, 769 .

\section{Stratigraphic.}

Cahuilla Basin : Free, 389.

Eocene of Coalinga-Cantua district: Taff, 1144.

Eocene of San Pedro Point: Mickerson, 316.

Interglacial periods, Sierra Nevada Mountains: Manson, 743 .

Jurassic slates, Monterey County: Davis, 289.

Martinez and Tejon formations: Dickerson, 317.

Mohave region formations, correlation : Merriam and Pack, 796.

Monterey series: Kew and Stoner, 597 ; Louderback, 703.

Neocene deposits, San Luis Obispo County: Martin, 748 .

Neocene of Sargent oil fields: Martin, 749 .

Orindan and Siestan formations: Merriam, 792.

San Tose and Mount Hamilton quadrangles : Templeton, $\mathbf{1 1 5 4 .}$

Sin liablo formation: Buwalda, 156 ; Clark, 207.

Sunta Lucia Mountains: Davis, 289.

Santa Susanna district: Johnson, 563; Waring, 1.232.

Sierra Nevada, bedrock complex: Louderback, 705.

Unconformity in Coalinga field: Ruck$\operatorname{man}, 1000$.

\section{Paleontology.}

Avian paleontology: Miller, 81.2.

Bathytoma, Pleistocene, San Fedro: Rivers, 9S5.

Camel, Pleistocene, Rancho Ta Brea: Merriam, 789.

Eocene fauna, Marysville Buttes : Dickerson, 314.

Horn from Molnave Miocene : Merriam, 790.

Horses, Rancho Le Brea: Merriam, 793.

Tertiary, Mohave Desert: Merriam, $794,795$.

Jurassic fauna, Slate's Springs : Davis, 289. 
California-Continued.

Paleontology-Continued.

Nothrotherium and Megalonyx from Pleistocene: Stock, 1118.

Orindan and Siestan faunas: Merriam, 792.

Rancho La Brea fauna: Merriam, 787. Scutella norrisi and Scutaster andersonl : Pack, 869.

Sharks : Jordan and Beal, 574.

Tapir, Cenozoic: Merriam, 788.

Tephrocyon: Merriam, 791.

\section{Petrology.}

Trachytic perlite, Lone Hill, San Jose : Postma, 924.

Mineralogy.

Bloedite crystals : Schaller, 1012.

Underground water.

Underground reservoirs : Lee, 667.

\section{Cambrian.}

Stratigraphy.

Alberta : Malcolm, 741.

Robson Peak district: Walcott, 1225.

Arctic regions, Ellesmere Land: Holtedahl, 518.

British Columbia; Cordilleran formations: Daly, 279.

Elko to Kootenay Lake: Schofield, 1020.

Robson Peak district : Walcott, 1225.

Rocky Mountains: Allan, 13.

West Kootenay and Boundary districts: Le Roy, 680.

Colorado, Monarch and Tomichi dis. tricts : Crawford, 266.

Cordillera, forty-ninth parallel: Daly, 278.

Georgia, Ellijay quadrangle: La Forge and Phalen, 643.

Idaho, Lemhi County : Umpleby, 1193. Montana, Helena region: Knopf, 626.

Philipsburg quadrangle: Emmons and Calkins, 360.

New Brunswick, St. John area : Young, 1347.

New York, southern Adirondacks: Miller, 820 .

North Carolina, Ellijay quadrangle : La Forge and Phalen, 643.

Ohio, Findlay borings: Condit, 252.

Nova Scotia: Malcolm, 740.

Cape Breton' Island, George River area : Young, 1347.

Pennsylvania, York Valley: Jandorf, 551.

Quebec: Young, 1347.

Gaspe Peninsula: Clarke, 213.

New Quebec territory: Denis, 309.

Tennessee, Ellijay quadrangle: La Forge and Phalen, 643.

Utah, Randolph quadrangle: Richardson, 977 .

San Francisco district: Butler, 147. Wasatch Mountains: Hintze, 507; Loughlin, 706 .
Cambrian-Continued.

Stratigraphy-Continued.

Vermont, Taconic Mountains: Keith, 583.

Virginia, James River basin: Taber, 1141.

Piedmont region: Watson and Cline, 1244.

Paleontology.

Arctic regions, Ellesmere Land: HoltedahI, 518.

Brachiopoda, habitat: Burling, 139.

British Columbia, Field : Walcott, 1227.

Eldonia, restoration: Clark, 204.

Fauna, origin : Matthew, 7.73.

Holothurians: Clark, 205.

Olenellus fauna: Matthew, $\mathbf{7 7 3}$.

Canada (general). See also names of Provinces.

General.

Bibliography, 1908-1011: Reinecke, 968.

Gulf of St. Lawrence, origin : Clarke, 210.

Mines Branch, Summary report, 1912 : Canada, M. B., 174.

Economic.

Coal : Dowling, 329

Coal fields, western Canada: Lakes, 645 .

Economic minerals : Canada, M. B., 173.

Fire-clay deposits : Ries, 981.

Mineral production 1911: McLeish, 738.

Petroleum and natural gas: Clapp and Huntley, 203.

Physiographic.

Gulf of St. Lawrence, origin : Clarke, 210.

Stratigraphic.

Geological map: Canada, G. S., 176.

Pre-Cambrian stratigraphy: Wilson, 1304.

Paleontology.

Asaphide: Raymond, 955.

Tetradium : Raymond, 956.

Trilobites: Raymond, 954.

Canal Zone. See Panama.

Carboniferous.

Stratigraphy.

General: Schuchert, 1027.

Black shale: Butts, 155

Alaska, Circle quadrangle: Prindle, 930.

Fairbanks quadrangle: Prindle, 929.

Koyukuk-Chandalar region: $\mathrm{Mad}$ dren, 739

Noatak-Kobuk region: Smith, 1068.

Alberta : Malcolm, 741.

Lake Minnewanka: Shimer, 1045.

Rocky Mountains: Allan, 13.

British Columbia, Coast Range : Camsell, 171.

Elko to Kootenay Lake: Schofield, 1020.

West Kootenay and Boundary districts : LeRoy, 680. 
Carboniferous-Continued.

Stratigraphy-Continued.

Colorado, foothills, Permian : Butters, 153.

Monarch and Tomichi districts : Crawford, 266.

Cordillera, forty-ninth parallel: Daly, 278.

Idaho, Lemhi County : Umpleby, 1193. southeastern: Schultz and Richards, 1030.

Illinois, Tallula, and Springfield quadrangles: Shaw and Savage, 1042.

Iowa : Keyes, 604.

Mexico, Coahuila: Haarman, 453.

Michigan, Arenac County: Gregory, 442.

Missouri: Keyes, 604.

Montana, Helena region : Knopf, 626.

Philipsburg quadrangle; Emmons and Calkins, 360.

western : Prardee, 880 .

New Brunswick, Moncton, Albert mines : Young, 1347.

St. John area: Young, 1347.

New Mexico: Case et al., 185.

Nova Scotia : Hyde, 543 ; Malcolm, 740.

Cape Breton Island, George River area : Young, 1347.

Joggins section: Bell, 63.

New Glasgow area: Young, 1347.

Sydney coal field: Hudson, 537; Young, 1347.

Windsor-Horton: Bell, 63.

Ohio, Bedford and Berea formations: Burroughs, 140.

Conemaugh formation : Condit, 251 ; Mark, 747.

Oklahomn, Red beds: Snider, 1078.

Penusylvania, anthracite fields, sections: Griffith, 448.

Barnesboro and Patton quadrangles : Campbell et al., 169.

Panther Creek Valley : Richards, 975.

Pottsville-Allegheny boundary, interior province: White, 1273.

Quebec, Gaspe Feninsula: Clarke, 213.

Red beds, Kansas-Oklahoma-Texas : Gould, 420 .

Texas, Wichita region: Gordon, 416.

Utah, Randolph quadrangle: Richardson, 977.

San Francisco district: Butler, 147. Wasatch Mountains: Hintze, 507; Loughlin, 706.

Virginia, southwestern: Stose, 1127.

Washington, Covada district: Weaver, 1251.

West Virginia, Cabell, Wayne, and Lincoln countles: Krebs and Teets, 640.

Marion, Monongalia, and Taylor counties: Hennen and Reger, 479 .
Carboniferous-Continued.

Paleontology.

Alberta, Lake Minnewanka spiriferoids : Shimer, 1045.

Bolosaurus, 'Texas: Broom, 112.

Canada, eastern, fossil plants: Holden, 514.

Ctenoptychius, Permian, Kansas : Martin, 753.

Illinois, Mazon Creek, Amphibla: Moodie, 831.

Indiana, Crawfordsville, Onychister : Sollas, 1082.

New Brunswick, fern ledges at st. John : Stopes, 1121.

New Mexico, Permo-Carboniferous vertebrates: Case et al., 185.

Nova Scotia, Horton flora: White, 1271.

Joggins section: Bell, 63.

Sydney coal field flora: White, 1271

Ohio, Conemaugh fauna: Mark, 747.

Paleozoic Arachnida: Petrunkevitch, 911.

Permian leptile, Texas: Williston, 1295.

Rhode Island, Pawtucket, Crustacea : Haynes, 475.

West Virginia, Conemaugh faunn : Beede, 61.

fossil flora: White, 1271 .

Wyoming, Amsden fauna : Blackwelder, 76.

Embar fauna : Blackwelder, 76.

Carnotite.

Colorado: Curran, 271; Moore and Kithil, 835.

Utah: Curran, 271; Moore and Kithll, 835.

Green River: Hess, 485.

Cartography.

Earthquakes, map for locating: Joerg, 558.

Geologic map of world: Ahlburg, 10.

Geologic mapping: Barnett, 43 ; Smith, 1058 ; Stebinger, 1104.

Planetable mapping: Higgins, 496.

Recording field work: Clapp, 197 ; Kemp, 591.

Caverns. See Caves.

Caves.

Ice caves: Miller, 809 .

Mammoth Cave: Whitbeck, 1269.

Occurrence and origin: Barck, 38.

Cement and cement materials.

Alabama : Eckel, 342.

Arizona : Eckel, 342.

Arkansas: Eckel, 342.

California : Eckel, 342.

Colorado: Eckel, 342.

Connecticut: Eckel, 342.

Delaware : Eckel, 342.

Florida : Eckel, 342.

Georgia : Eckel, 342.

Idaho: Eckel, 342. 
Cement and cement materials-Continued. Illinois : Eckel, 342.

Indiana : Eckel, 342.

Iowa : Eckel, 342 .

Kansas : Eckel, 342.

Kentucky : Eckel, 342.

Ionisiana : Eckel, 342.

Maine : Eckel, 342.

Maryland : Wckel, 342.

Massachusetts : Eckel, 342.

Michigan : Eckel, 342.

Minnesota : Eckel, 342.

Mississippi : Eckel, 342.

Missouri : Eckel, 342.

Montana : Eckel, 342.

Nebraska : Eckel, 342.

Nevada : Eckel, 342.

New Hampshire: Eckel, 342.

New Jer'sey : EckeI, 342.

New Mexico: Eckel, 342.

New York: Eckel, 342 ; Newland, 844.

North Carolina: Eckel, 342.

North Dakota: Eckel, 342.

Ohio: Eckel, 342.

Oklahoma : Eckel, 342.

Oregon: Eckel, 342.

Pennsylvania : Iickel, 342.

Rhode Island: Eckel, 342.

South Carolina : Eckel, 342.

South Dakota: Eckel, 342.

Tennessee : Eckel, 342.

Texas: Eckel, 342.

United States : Burchard, 137 ; Eckel, 342 .

Utah : Eckel, 342.

Vermont: Eckel, 342.

Virginia: Eckel, 342.

Washington : Eckel, 342.

West Virginia: Eckel, 342.

Central America. See also Costa Rica; Guatemala, etc.

Volcanoes: Sapper, 1.006.

Cephalopoda, See also Mollusca. Biogenetic law: Smith, 1065.

Devonian, catalog of: Frech, 387.

Maryland Devonian: Clarke and Swartz, 214; Ohern and Maynard, 858; Prosser and Kindle, 935.

Chalcocite enrichment: Spencer, 1087.

Changes of level. See also Beaches; Shore lines; Terraces.

Cause: Baker, 27 ; Spencer, 1090.

Chamæcyparis bog, Woods Hole, Massachusetts: Johnson, $\mathbf{5 6 0}$.

Coastal subsidence: Johnson, 561.

Great Lakes region: Spencer, 1093 .

New York, postglacial: Spencer, 1088 .

Ontario, postglacial : Spencer, 1088.

Pleistocene crustal movements in Mississippi Valley: Todd, 1161.

Quebec: Goldthwait, 411. postglacial : Spencer, 1088.

Chemical analyses. See list, p. 162.
Chert. S'ee Flint.

Chromite.

British Columbia, Tulameen district: Camsell, 170.

Quebec: Harvie, 466.

Chromium.

General: Phalen, 918.

Cirques.

New Hampshire, White Mountains: Goldthwait, 410.

Classification.

Faulting: Reid et al., 967 .

Mineralogical, of gradational rocks: Lincoln, 690 .

Sand dunes: Haltenberger, 459.

Clay. See also Fire clay.

General: Hance, 461.

British Columbia, Clayburn, fire-clay deposits : Camsell, 171.

Delaware: Matson, 766.

Florida, analysis: Hall, 458.

Maine, Portland region: Katz, 579.

New York: Newland, 844.

Ontario, 'Torontó : Baker, 29.

Oregon: Geijsbeek, 397.

United States: Middleton, 808.

Climate, Geologic. See Paleoclimatology.

Coal. See also Anthracite; Lignite.

General: McInnes et al., 733.

Analyses: Lord et al., 702 ; U. S. G. S., 1201.

Classification : Gordon, 419.

Formation of : Jeffrey, 554 .

Formation of coal beds: Stevenson, 1109, 1111.

Sand classification: Smith et al., 1064.

Origin : Burroughs, 143.

sapropelic hypothesis: Jeffrey, 553.

Roots in underclays: White, 1272, 1274.

Alaska: Brooks and Martin, 110.

Bering River field: Crane, 260-263.

Circle quadrangle: Prindle, 930.

Kodiak Island: Martin, 750.

Matanuska field: Crane, 264, 265.

Noatak-Kobuk region: Smith, 1068.

Alberta, western: Leach, 666.

British Columbia, Peace River canyon : Galloway, 394.

Queen Charlotte Islands : Clapp, 201.

Tulameen district: Camsell, 170.

Vancouver Island: Clapp, 199. southern : Clapp, 200.

Canada: Dowling, 329.

western: Lakes, 645.

Idaho, Goose Creek district, Cassia County : Bowen, 92

Horsëshoe Bend and Jerusalem VaJley: Bowen, 91.

southeastern: Schultz and Richards, 1030.

Illinois : Bement, 65.

Tallula and Springfield quadrangles : Shaw and Savage, 1042. 
Coal-Continued.

Kentucky, Harlan field: Peck and Sampson, 895 .

Mexico: Hill, 502 ; Schwar\%, 1031.

Montana: Stebinger, 1105.

Little Sheep Mountain field: Rogers, 995.

southwestern: Pardee, 881.

New Brunswick: Gray, 438.

Newfoundland: Howley, 532.

New Mexico, Cerrilios field, Santa Fe County : Lee, 670.

North Dakota, Williston lignite field: Ferald, 481

Nova Scotia: Gray, 438; Lawson, 664.

Cape Breton: Anon., I357.

Sydney coal fields, Cape Breton: Hudson, 537.

Ohto: Burroughs, 142

Oklahoma, McAlester field: Brown, 125.

Pennsylvania, Barnesboro and Patton quadrangles: Campbell et al., 169.

Panther Creek Valley: Richards, 975.

'Tennessee, north of Tennessee Central Railload: Glenn, 409.

south of 'Tennessee Central Railroad : Nelson, 842.

Texas, Webb County: Miller, s1.1.

ITrinidad: Catherall, 186.

United States : Campbell, 168 ; Parker, 883.

Washington, Cowlitz River valley : Collier, 242.

West Vilginia, Cabell, Wayne, and Lincoln counties: Krebs and 'l'eets, 640.

Marion, Monongalia, and T'aylor counties: Hennen and Reger 479.

Pocahontas field: Stow, 1130.

Wyoming, Barbour coal field, Johnson County : Wegemann, 1259.

Yukon, Tantalus area : Cairnes, 159.

Coal beds, formation of: Stevenson, 1109, 11.1.

Coal measures. Sce Carboniferous.

\section{Cobalt.}

Idaho, Lemhl County: Umpleby, 1193.

Ontario, Cobalt area: Miller, 815,817 .

United Stutes: Hess, 488.

Cobalt series: Wilson, 1303.

Celenterata. See also Anthozoa ; Hydrozon. Maryland, Devonian: Clarke and Swartz, 214; P'rosser, 834 ; Swartz, 1134.

Polyphyletic genera: Grabau, 428. T'etradium, Canada : Raymond, 956.

\section{Colemanite.}

Origin : Gale,392.

\section{Colorado.}

General.

Cripple Creek district, topographic model: Byler and Davis, 157.

Geology of Moffat tunnel: Bancroft, 34.

Economic.

Alunite, San Cristobal quadrangle: Larsen, 658.

Brush Creek region: George, 399.

Carnotite: Curran, 271. Moore and Kithil, 835.

Creede district: Emmons and Iarsen, 362.

Cripple Creek district, replacement deposits: Colburn, 229.

De Beque oil field: Woodruff, 1325.

Iron ore, titaniferous, Cebolla: Singewald, 1055.

Leadville deposits : Rose, 999.

zinc ores: Butler, 152.

Mica deposits, Mesa County: Sterrett, $\mathbf{1 . 1 0 6 .}$

Monarch and 'Tomichi districts : Crawford, 266.

Mosquito district, lark County : Moore, 834.

]itchblende, Gilpin County: Rickard, 978.

Rico district: Ritter, 984 .

Sulphur deposits, Mineral County Larsen and Funter, 659.

'Tungsten, Boulder County: P'almer, 879.

Vanadium deposits, Placerville, Hess, 486.

Wagon Wheel Gap, mineral deposits Emmons and Larsen, 363 .

Physiographic.

Golden district: Schneider, 1019.

Monarch and Tomichi districts : Crawford, 266

Stratigraphic.

Brush Creek region: George, 399.

Creede district: Emmons and Larsen, 362.

Monarch and Tomichi districts : Crawford, 266 .

Permian, foothills : Butters, 153.

Rabbit Ears region: Grout et al., 450 .

Raton Mesa region: Knowlton, 632; Lee, 671 .

Red Beds: Henning, 480.

Paleontology.

Birds, fossil, Florissant: Shufeldt, 1052 .

Dinosaurs, Tertiary: Lee, 671.

Florissant fauna: Cockerell, 228. insects: Cockerell, 220, 221, 226. Anthomyid fly: Cockerell, 217. Asilid fly: Cockerell, 225. Coleoptera: Wickham, 1281, 1282. Isoptera : Cockerell, 216. Mydaid fly: Cockerell, 224. Odonata: Calvert, 165. Phryganea : Cockerell, 222. 
Colorado-Continued.

Paleontology-Continued.

Fossil flowers and fruits: Cockerell, 218.

Ordovician(?) fish remains: Cockerell, 219.

Tertiary dinosaurs: Lee, 671.

Petrology.

Magnetite basalt, North Park: Washington and Larsen, 1237.

Monarch and Tomichi districts : Crawford, 266.

Rabbit Ear's region: Grout et al., 450 . Mineralogy.

Calcium vanadates: Hillebrand et $a l$, 505.

Hetærolite, Leadville : Ford and Bradley, 384.

Minerals and rocks: George, 398.

Underground water.

Hot Springs, Wagon Wheel Gap : Iimmons and Larsen, 363.

Mineral springs, Manitou: Shedd, 1043.

Combretanthites eocenica : Berry, 72.

Concretions.

Formation, Mexico: Whfte, $\mathbf{1 2 7 5}$.

Conglomerate: Lawson, 662.

Conglomerates.

Paleozolc, origin: Brown, 124.

Congresses. See Associations.

Connecticut.

Dynamic and structural.

Peat deposit, New Haven : Davis, 288.

\section{Contact phenomena.}

Colorado, Monarch and. Tomichi districts: Crawford, 266.

Silicate zones, origin: Uglow, 1184.

Virginia, middle western: Watson and Copper. Cline, 1243.

General: Thompson, 1157.

Chalcocite, origin: MacCallum, 742.

Chalcocite enrichment: Spencer, 1087.

Disseminated replacement deposits : Botsford, 89.

Enrichment: Graton, 435.

Sulphide ores, microscopic study: Graton and Murdoch, 437.

Sulphide ores, microscopic study: Read, 960.

Alaska, Chitina Valley: Moffit, 828.

Ellamar district: Capps and Johnson, 178.

Noatak-Kobuk region: Smith, 1068.

Arizona : Ransome, 945; Weed, 1.257.

Bisbee district: Notman, 853.

Oro Blanco district: Milton, 823 .

Turquoise district: Ransome, 946 .

British Columbia, Atlin district: Cairnes, 158.

coast region: Bancroft, 35 .

Granby Bay: McConnell, 719.

Lynn Creek district: Emmens, 351.

'Tulameen district: Camsell, 170.

Copper-Continued.

California, Shasta County: Gilbert and Pogue, 405 ; Storms; 1125 ; Whitman, 1279.

Woody district: Storms, 1126.

Colorado, Monarch and Tomichi districts : Crawford, 266.

Rico district: Ritter, 984.

Idaho, Custer County: Umpleby, 1195.

Lembi County : Umpleby, 1193.

Loon Creek district: Umpleby, 1194.

Mexlco, Jalisco, Magistral district: Ordóñez, 860.

Puebla, Sierra Magistral district: Brinsmade, 103.

Montana, Butte: Rogers, 992; Sales, 1001 ; Weed, 1256.

Helena region : Knopf, 626.

New Mexico, Bent: Ball, 31.

Ontario, Massey mine area: Coleman, 233.

Whiskey Lake area: Coleman, 232.

Pennsylvania, York County: Jandorf, 552.

Tennessee, Ducktown: Gilbert and Pogue, 405.

Ellijay quadrangle: La Forge and Phalen, 643 .

Virginia, James River basin: Taber, 1141.

United States: Butler, 150.

Utah, San Francisco district: Butler, 147.

Coral reefs and islands.

General: Grabau, 425 ; Vaughan, 1210.

Dana's confirmation of Darwin's theory : Davis, 293, 297.

Cuba: Corral, 258.

Corals. See Anthozoa.

Cordillera: Schofield, 1020.

Correlation. See Stratigraphic.

Costa Rica.

Earthquake, Sarchi, 1912: Sapper, 1.005.

Volcanic rocks: Alfaro, 12.

Covada district, Washington : Weaver, 1251.

Crater Lake: Martin, 756.

Cretaceous.

Stratigraphy.

General.

Variations in Upper Cretaceous stratigraphy : Stanton, 1101.

Alaska, Circle quadrangle: Prindle, 930.

Fairbanks quadrangle: Prindle, 929.

Koyukuk-Chandalar region: Maddren, 739 .

Noatuk-Kobuk region: Smith, 1068.

Alberta : Dowling, 327; Malcolm, 741.

Edmonton area: MacLean, 736.

Rocky Mountains: Allan, 13.

western : Leach, 666.

Arizona, Sulphur Spring Valley: Meinzer and Kelton, 785 . 
Cretaceous-Continued.

Stratigraphy-Continued.

British Columbia, Coast Range: Camsell, 171.

eastern : Leach, 666

Peace River canyon: Galloway, 394.

Skeena River district: McConnell, 71.9 .

Colorado, Rabbit Ears region: Grout et al., 450 .

Raton Mesa region: Knowlton, 632.

Cordillera, forty-ninth parallel: Daly, 278.

Delaware: Matson, 766.

Idaho, southeastern : Schultz and Richards, 1030.

Iowa: Keyes, 609.

Manitoba: Malcolm, 741.

Mexico, Coahulla: Haarman, 453. northeastern: White, 1275.

Montana: Stebinger, 1105.

Helena region: Knopf, 626.

Little Sheep Mountain fleld: Rogers, 995.

Philipsburg quadrangle: Emmons and Calkins, 360 .

New Mexico, Cerrillos field, Santa Fe County : Lee, 670.

Raton Mesa region: Knowlton, 632 .

North Dakota: Leonard, 678.

Saskatchewan: Malcolm, 741.

Texas, Wichita region: Gordon, 416.

Virginia, Coastal Plains: Sanford, 1004.

\section{Paleontology.}

Alabama, Tuscaloosa flora: Berry, 72.

Alberta, Ceratopsia : Lambe, 651.

Trachodon from Edmonton formation: Lambe, 649.

British Columbia, Kettle River region, plants: Penhallow, 898.

Kansas, fish: Woodward, 1327.

T.eurospondylus, Alberta : Brown, 124.

Mexico, Coahuila: Böse, 85.

New Jersey, Cliffwood, Pityoxyla: Holden, 513.

sponge: Shimer and Powers, 1046.

Wyoming, Glelchenia: Knowlton, 633.

Crinoidea. See also Echinodermata.

Cremacrinidæ: Ulrich, 1189.

Maryland, Devonian : Ohern, 857.

Merocrinus : Bather, 57.

Ottawacrinus: Bather, 57.

Plicatocrinidæ, systematic position: Clark, 206.

Scyphocrinus and Camarocrinus : Springer, 1.095.

Scyphocrinus slab : Bassler, 51.

Cross-bedding, White River formation, South Dakota : Winchester, 1313.

\section{Crustacea.}

Coal Measures, Pawtucket, Rhode Island : Haynes, 475.

Panama, Gatun fauna: Brown and Pilsbry, 115.
Cryolite.

United States: Burchard, 137.

Cryptogams. See Paleobotany.

Crystallography.

General.

Model to illustrate symmetry: Phillips, 919.

Monoclinic crystals, conventional position: Gill, 406

Delafossite : Rogers, 989

Hodgkinsonite, Franklin Furnace, New Jersey: Palache and Schaller, 876.

Natramblygonite: Schaller, $\mathbf{1 0 1 5}$.

Willemite: Palache and Graham, 875.

Cuba. See also West Indies:

General.

Isle of Pines: Jennings, 556.

Economic.

Batabano phosphates: Corral, 258.

Iron ores: Willey, 1285.

Stratigraphic.

Jurassic, western Cuba: Torre, 1.166.

Paleontology.

Mammalia: Matthew, $\mathbf{7 8 0 .}$

Pleistocene Mammalia: Torre, 1167.

Quaternary fossils: Brown, 118.

Cyclocystoides: Raymond, 953.

Cystoidea.

Cyclocystoldes: Raymond, 953.

Maryland, Devonian: Schuchert, 1024.

Decomposition of rocks. See Weathering.

Definitions. See Nomenclature.

\section{Deformation.}

General: Leith, 676.

Deformations, excavation : Mac1Donald, 727.

Delaware.

Economic.

Clay deposits: Matson, 766 .

Deltas.

General: Grabau, 425.

Faleozoic: Grabau, 427.

Upper Devonian, Appalachian geosyncline : Barrell, 45.

Deposition. See also Sedimentation.

Continental deposits: Keyes, 612.

Deposition of ores. See Ore deposits, origin.

Devonian.

Stratigraphy.

General: Schuchert, 1.027.

Black shale: Butts, 155.

Onondilyil, unconformity at base: Kindle, 616.

Upper Devonfan delta of Appalachian geosyncline: Barrell, 45.

Alaska, Circle quadrangle: Prindle, 930.

Fairbanks quadrangle: Prindle, 929.

Koyukuk-Chandalar region: Mad. dren, 739 .

Alberta: Malcolm, 741.

Lake Minnewanka: Shimer, 1045.

Rocky Mountuins: Allan, 13. 
Devonian-Continued. Stratigraphy-Continued.

British Columbia, Elko to Kootenay Lake: Schofield, 1020.

Colorado, Monarch and Tomichi districts : Crawford, 266.

Cordillera, forty-ninth parallel: Daly, 278.

Idaho, Lemhi County: Umpleby, 1193.

Iowa: Keyes, 604, 610 .

Floyd County : Thomas, 1155.

Maine, Eastport quadrangle: Bastin and Williams, 56.

Manitoba : Malcolm, $\mathbf{7 4 1}$.

Snake Island and Lake Winnipego. sis: MacLean, 736.

Maryland: Md. G. S., 764; Prosser ot al., 937 ; Schuchert et al., 1029 ; Swartz, 1132 .

correlation: Swartz, 1133.

Devonian, Lower, sections: Swartz et $a l ., 1139$.

Upper: Prosser and Swartz, 936; Swartz, 1135, 1136.

Michigan, Detroit River area, Anderdon limestone: Nattress, 840 .

Missouri : Keyes, 604.

Montana, Helena region : Knopf, 626.

Philipsburg quadrangle: Emmons and Calkins, 360.

New Hampshire, Littleton area: La hee, 644 .

New York, Niagara quadrangle: IKindle and Taylor, 619.

Tropidoleptus zones: Williams, 1288.

Nova Scotia : Malcolm, 740.

Ohio, northern, Huron and Cleveland shales: Prosser, 932.

Ontario : Parks, 886.

Hagersville district: Stauffer, 1102.

F'ort Colborne region: Stauffer, 1103.

Quebec, Dalhousie: Clarke, 213.

Gaspe Peninsula: Clarke, 213.

Saskatchewan: Malcolm, 741.

'Tennessee, eustern : Burchard, 135.

Utah, Randolph quadrangle: Richardson, 977.

San Francisco district: Butler, 147

Wasatch Mountains: Hintze, 507.

Paleontology.

Alberta, Lake Minnewanka spiriferoids : Shimer, 1045.

Roche Miette, helodont teeth : Lilmbe, 648.

Arctic regions, Ellesmere Latnd : Meyer, 807.

Illinois, arthropods: Savage, 1009.

Maryland: Md.G. S., 764 .

Devonian, Clarke and Swartz, 214.

Brachiopoda: Schuchert and Maynard, 1028.

Brachiopoda, Pelecypoda, Gastropoda, Cephalopoda, Trilobita : Prosser and Kindle, 935.

Bryozoa: Ulrich and Bassler, 1191.

Devonian-Continued.

Paleontology-Continued.

Maryland-Continued.

Devonian-Continued.

Cephalopoda: Ohern and Maynard, 858.

Cœlenterata : Prosser, 934 ; Swartz, 1134.

Crinoidea : Ohern, 857 .

Cystoidea: Schuchert, 1024.

Gastropoda: Ohern and Maynard, 858.

Ostracoda: Ulrich and Basier, 1191.

Pelecypoda: Ohern and Maynard, 858.

Pisces: Swartz, 1137.

Trilobita: Ohern and Maynard, 858.

Vermes: Kindle, 614; Ohern, 857.

Missouri, fishes: Branson, 99.

New Hampshire, Littleton area : Lahee, 644.

New York, Tropidoleptus zones: Williams, 1288

Quebec, Percé, trilobite: Clarke, 211.

Diamonds.

British Columbia, Tulameen district: Camsell, 170.

United States: Sterrett, 1107.

Diastrophism : Chamberlin, 191-194.

Dikes.

Arkansas, southwest-central : Miser, 826.

Pennsylvania, Fayette and Green coun- ties: Smith, 1066.

Virginia, middle western: Watson and Cline, 1243.

Shenandoah Valley: Watson and Cline, 1243.

Dinosauria.

Alberta : Brown, 117.

Hypacrosaurus: Brown, 120.

Saurolophus: Brown, 119.

Tertiary, Colorado: Lee, 671.

'Trachodon, manus: Brown, 122.

Wyoming: Gilmore, 408.

Dip, detcrmination of : Moon, S33.

Dip, graphical determination of: Cameron, 166.

Dislocations. See Fululting:

Distribution. See Geographic distribution.

Dolomite.

General.

formation of : Wallace, 1231.

Bighorn dolomite, Wyoming, origin : Blackwelder, 78 .

Dolomitization: Wallace, 1230.

Drainage changes.

Ohio, Licking County, Moot's Run area : Nixon and Tight, 850.

Pennsylvania: Hice, 494; Ortmann, 861.

Susquehanna River: Darton, 283. 
Drainage changes-Continued.

St. Clair and Detroit rivers, former distributaries: Taylor, 1.153.

Virginia, Shenandoah Valley: Watson and Cline, 1245.

Drift deposits. See also Glacial geology. General: Norton, 852 .

Drift pebbles, leaching of: Udden, 1182.

Dynamic and structural (general). For regional, see names of States. See also list of subject headings on p. 113.

Gencral: Grabau, 425; Leith, 676 ; Von Eugeln, 1217.

Atmospheric agencies: Chamberlin, 195.

Cone in cone structure in coal: Woodruff, 1326.

Cross-bedding, White River formation, South Dakota: Winchester, 1313.

Diastrophism : Chamberlin, 191-194. shelf-seas: Chamberlin, 192. later creep: Chamberlin, 193. rejuyenation of the continents: Chamberlin, 194.

Excavation deformations: Macloonald, 727 .

Flow of rocks: Adams, 5.

Frost crystals formed underground : Neiswender, 841.

Pelitic sediments and magmatic differentiation: Hobbs, 51.0.

Rock-boring shells, geologic significance: Barrow, 48 .

Pre-Cambrian ocean: Daly, 280.

Pseudobrecciation in Ordovician limestones: Wallace, 1230.

Soil flow: Hobbs, 509.

Submarine slide: Hahn, 457.

Waves: Cornish, 256.

Dynamic geology: Von IEngeln, 1.217.

Earth, temperature.

Ohio, Findlay borings: Tohnston, 561.

Earth movements. Sec Landslides.

Earthquakes, See also Seismology.

General: Branner, 97.

Rainfall, relition to: Sayles, 1011.

California, registration at Berkeley station, 1912 : Davis, 290.

Costa Rica, Sarchi: Sapper, 1005.

Mexico, Guadalajara: Ordoñez, 859.

Talisco, June 7, 1911: Miranda y Marron, 825.

Missouri, New Madrid: Sampson, 1003.

Nova Scotia, Cape Breton: McIntosh, 734.

Ontario, April 28, 1913 : Klotz, 622.

South Carolina: Taber, 1142.

Tennessee, eastern : Gordon, 418.

Virginia, Buckingham County: Taber, 1143.
Echinodermata. Sce also Asteroidea; Blastoiden ; Crinoidea ; Cystoidea ; Echinoidea.

Cambrian holotburians: Clark, 205.

Maryland, Devonian: Clarke and Swaltz, 21.4.

Echinoidea.

California, Scutella and Scutaster : Pack, S69.

Economic (general). For regional sce names of States. Sce also Ore deposits, origin; and the particular products.

General: Storms, 1124.

Contact zones: Kemp, 594.

Fineness of gold : Knopf, 629.

Investigation of copper enrichment Graton, 435.

Jiterature, recent: Knopf and Umpleby, 631; Paige and Lloyd, 873.

Microscopical petrography: Wadsworth, 1220.

Microscopy in economic geology : Beck, 58.

Mineral deposits: Lindgren, 698.

Mineral fuels: Campbell, 167.

Ore, definition: Ireele, 896.

Ore bodies at Cripple Creek: Colburn, 230.

Ore deposits: Emmons, 352.

influence of depth : Kemp, 596.

Precipitation of gold and silver: Palmer and Bastin, 877.

Protore: Ransome, 947.

Secondary enrichment in silver: Bastin, 53.

Sulphides, order of origin : 'T'hompson, 1157.

Textbook: Richardson, 976.

.. Titaniferous magnetite, structure: Singewild, 1056.

Educational. See also Textbooks.

Laljoratory exercises in structural and historical geology: Salisbury and 'Il'rowbridge, 1002 .

Study of minerals and rocks: Holt, 517.

jolevation and subsidence. Scc Changes of level.

Ellijay quadrangle: Lal Forge and Platen, 643.

Emery.

New York: Newland, 844.

Enchodus, teleostean : Green, 439.

Intomolestes: Gregory, 447.

Eocene. Sce Tertiary

Eolation. See Wind work.

Folian action. See Wind work.

Eomoropus: Oshorn, 863.

Eotitanops: Osborn, 864

Eozoon, Côte St. Pierre, Quebec: Stans. field, 1101. 
Erosion. See also Glacial erosion; Sedimentation.

Cycle of erosion: Davis, 295.

Glacial erosion: Davis, 292.

Sea caves at La Jolla: Winsted, 1314.

Tennessee, western: Purdue, 942.

Eruptive rocks. See Igneous and volcanic rocks.

IEssays. See Addresses.

Eurypterids: Grabau, 427; distribution and occurrence: O'Connell, 854.

Evolution.

General: Matthew, 774 .

Excavation deformations: MacDonald, 727.

Experimental investigations:

General: Wright, 1342.

Vadose synthesis of pyrite: Whitman, 1279.

Fairbanks quadrangle, Alaska: Prindle, 929.

Fanglomerate: Lawson, 662 .

Faulting.

General: Leith, 676 .

Graphics applied to fault problems : Rice, 969.

Nomenclature: Reid et al., 967.

Nomenclature of surface forms: Davis, 295.

Colorado, Monarch and Tomichi districts: Crawford, 266.

Idaho, southeastern, Bannock fault: Richards and Mansfield, 974.

Mexico, Coahuila: Haarman, 453.

Montana, Butte district: Sales, 1001. overthrust fault in nearly flat strata: Rogers, 997.

Philipsburg quadrangle: Emmons and Calkins, 360 .

Utah, Wasatch Mountains: Hintze, 507 ; Loughlin, 706.

Virginia, Piedmont region: Watson and Cline, 1244.

Feldspar.

Appalachians, southern: Watts, 1.250.

New York: Newland, 844.

Ontario: Schmid, 1018.

Kingston district: Baker, 28 .

Quebec: Schmid, 1018.

United States: Katz, 580.

leldspars, melting phenomena : Bowen, 95.

Field work.

General: Anderson, 17; Ball, 30 ; Irving, 547, 548; Hartley, 464; Ohern, 856; Richards, 971; Smith, 1072.

Fossils in stratigraphic work: Schuchert, 1026.

Geologic mapping: Barnett, 43 ; Smith, 1058; Stebinger, 1104.

Glacial geology : Leverett, 682.

Measuring dip: Mosier, 837.

Measuring strata: Blackwelder, 76; Woodruff, 1324 ,
Field work-Continued.

Measurements: Barrell, 44.

Note taking: Purdue, 944.

Penfield protractor: Calkins, 163.

Planetable mapping: Gardner, 396.

Recording data: Clapp, 197; Crawford, 267 ; Kemp, 591; Smith, 1062 ; Stose, 1128.

Fire clay.

Canada: Ries, 981.

Fishes. See Pisces.

Fissures. See Faulting.

Florida.

General: Vaughan, 1210, 1212.

Administrative report, State survey: Sellards, 1035.

Soils, classification: Sellards, 1034.

leconomic.

Clay, analysis : Hall, 458.

Phosphates, origin: Sellards, 1036, 1037.

D.ynamic and structural.

Oolite, formation of: Vaughan, 1211.

Physiographic.

General: Matson and Sanford, 768.

stratigraphic.

General: Matson and Sanford, 768.

Underground water.

General: Matson and Sanford, 768 .

Artesian water supply, eastern and southern Florida: Sellards and Gunter, 1038.

Florissant, Colorado, fauna : Cockerell, 228.

Fluorspar.

United States: Burchard, 137.

Folding.

Idaho, southeastern: Richards and Mansfield, 973.

Mexico, Coahuila: Haarman, 453.

Montana, Philipsburg quadrangle: Emmons and Calkins, 360.

New York, Trenton Falls: Habn, 457.

Footprints.

Liansas, vertebrate: Moodie, 830 .

Fossil forest, Arizona: Merrill, 800.

Fossils. S'ee Paleontology.

Franklin.

Mineralogy.

Prehnite from Adams Sound: Johnston, 567.

Fuller's earth.

General: Parsons, 893.

Arkansas: Miser, 826.

United States: Middleton, 808.

Gallina quadrangle, New Mexico : Case, 183.

Garnet.

New York: Newland, 844.

Warren County: Miller, 821.

Gas. See Natural gas. 
Gastropoda. See also Mollusca.

Bathytoma, Pleistocene, San Pedro: Rivers, 985.

Martinique, Miocene Mollusca : Cossmann, 259.

Maryland, Devonian: Clarke and Swartz, 214; Ohern and Maynard, 858; Prosser and Kindle, 935.

Panama, Miocene Mollusca : Cossmann, 259.

Goms. See Precious stones.

Genesis of ores. See Ore deposits, origin.

\section{Geochemistry.}

General: Hartzell, 465.

Analysis of rocks: Connor, 253.

Calcium vanadates: Hillebrand et al., 505.

Chalcocite enrichment: Spencer, 1087.

Contact zones: Uglow, 11.84.

Electrochemical activity between solutions and ores: Wells, 1262.

Metallic minerals as precipitants of silver and gold: Palmer and Bastin, 878.

Mineral analyses: Wright and Van Orstrand, 1343.

Mineral separations by heavy solutions: Hillebrand, 503.

Precipitation of gold and silver : Palmer and Bastin, 877.

Pyrite, vadose synthesis: Whitman, 1279.

Silver, enrichment: Cooke, 254.

Solubflity of constituents of rocks: Smyth, 1075.

Sulphide enrichment: Emmons, 358; Grout, 449

Sulphides of zinc, cadmium, and mercury: Allen and Crenshaw, 14.

Geologic climate. See Paleoclimatology.

Geologic formations described. See list p. 165.

Geologic history, See also Paleoclimatology ; Paleogeography.

Alaska, Circle quadrangle: Prindle, 930.

Fairbanks quadrangle: Prindle, 929.

Noatak-Kobuk region: Smith, 1068.

Nome and Grand. Central quadrangles : Moftit, 827.

Rampart quadrungle : Eakin, 335.

Appalachians, northern, post-Jurassic : Barrell, 47.

Arizona, San Franciscan field: Robinson, 987.

Sulphur Spring Valley : Meinzer and Kelton, $\mathbf{7 8 5}$.

British Columbia, Fraser delta : Camsell, 171.

interior plateau region: Drysiale, 331.

Tulameen district: Camsell, 170.

$88416^{\circ}-$ Bull, $5 \$ 4-14-9$
Geologic history-Continued.

California, southern, Tertiary : Louderback, 703 .

Canada, Gulf of St. Lawrence : Clarke, 21.0.

Colorado, Monarch and Tomichl districts: Crawford, 266.

Cordillera, Canada: Schofield, 1020.

forty-ninth parallel: Daly, 278.

Florida: Matson and Sanford, 768.

Georgia, Ellijay quadrangle: La Forge and Phalen, 643.

Glacial : Fairchild, 366.

Great Lakes region: Taylor, 1148, 1149.

Idaho, Lemhi County: Umpleby, 1193.

Illinois, Tallula and Springfield quadrangles: Shaw and Savage, 1042.

Maine, Portland and Casco Bay quadrangles: Katz, 578.

Mexico, Coahuila: Haarman, 453.

Montana, F'hilipsburg quadrangle : Emmons and Calkins, 360.

southwestern : Pardee, 881.

New York, Adirondacks, soutbern : Miller, 820.

glacial : Fairchild, 366 .

Niagara Falls and gorge: Taylor, 1149.

Niagara quadrangle: Kindle and Taylor, 619.

Niagara Falls: Spencer, 1091.

Niagara gorge and Great Lakes history : Taylor, 1152.

Nova Scotia: Malcolm, 740.

Ontario, Niagara Falls and gorge: Taylor, 1149.

Pleistocene: Taylor, 1150.

Oregon, Tertiary: Arnold and Hanntbal, 18.

Pennsylvania, Barnesboro and Patton quadrangles: Campbell et al., 169.

'Tertiary, southern California : Louderback, 703 .

Utah, Boxelder and Tooele countles: Carpenter, 181.

San Francisco district: Butler, 147.

Virginia, James River basin: Taber, 1141.

Washington, Covada distrlct: Weaver, 1251.

south central: Waring, 1233.

Tertiary: Arnold and Hannibal, 18.

Wyoming, Wind River Mountains, Cenozoic history: Westgate and Branson, 1265.

Geologic maps.

Alabama : Eckel, 342.

Alaska, Circle quadrangle: Prindle, 930.

Ellamar distrlet: Capps and Johnson, 178.

Fairbanks quadrangle: Prindle, 029.

Grand Central quadrangle: Moffit, 827. 
Geologic maps-Continued.

Alaska: Kodiak and neighboring islands: Martin, 750.

Koyukuk-Chandalar region: Maddren, 739 .

Noatak-Kobuk region: Smith, 1068.

Nome quadrangle: Moffit, 827.

Rampart and Hot Springs districts : Eakin, 335 .

Ruby, Innoko, and Iditarod districts : Eakin, 336.

Seward Peninsula: Moffit, 827; Smith, 1070.

southeastern, Prince Rupert to Skagway: Wright, 1338.

Yentna district: Capps, 177.

Alberta : Bryce, 131 ; Malcolm, 741.

Banff-Golden : Allan, 13.

Blairmore-Frank coal fields: Dowling, 329 .

coal fields: Dowling, 329.

Crowsnest Mountain : Leach, 666.

Laggan-Field : Allan, 13.

Arizona, Elden Mountain: Robinson, 987.

San Franciscan field: Robinson, 987.

Sulphur Spring Valley: Meinzer and Kelton, 785.

Turquoise district: Ransome, 946.

Arkansas: Eckel, 342.

southwest-central : Miser, 826.

British Columbia, Agassiz-Vancouver : Camsell, 171.

Albert Canyon area: Daly, 279.

Atlin district, Taku Aı'm: Cairnes, 158.

coal fields: Dowling, 329.

coast region: Bancroft, 35 .

Crows Nest coal fields: Dowling, 329.

Crowsnest Mountain : Leach, 666.

Ducks-Lytton: Drysdale, 331.

Elko to Kootenay Lake: Schofield, 1020.

Glacier area: Daly, 279.

Golden-Revelstoke: Daly, 279.

Laggan-Field : Allan, 13.

Lytton-Agassiz: Camsell, 171.

Midway to Princeton: Camsell, 1.72.

Prairie Hills and Dogtooth Mountains: Daly, 279.

Procter to Midway: LeRoy, 680 .

Prince Rupert to Telkwa: McConnell, 719.

Princeton to Spence Bridge: Camsell, 1.72 .

Revelstoke-Ducks : Daly, 279.

Tulameen district: Camsell, 170.

Vancouver Island, southern : Clapp, 200.

Victoria area : Clapp, 199.

California: Eckel, 342.

Marysville Buttes region: Dickerson, 314.

Trinity and Siskiyou counties: MacDonald, 722 .
Geologic maps--Continued.

Canada, coal areas: Dowling, 329.

economic minerals: Canada M. B., 173.

Canada and Newfoundland: Canada G. S., 176 ; Young, 1347.

Colorado, De Beque field: Woodruff, 1325.

Eagle County: George, 399.

Monarch and Tomichi districts : Crawford, 266.

Rabbit Ears region: Grout et al., 450.

Cordillera, forty-ninth parallel : Daly, 278.

Florida: Eckel, 342 ; Matson and Sanford, 768 .

Georgia: Eckel, 342.

Ellijay quadrangle: La Forge and P'halen, 643.

Idaho: Bell, 63.

Custer County: Umpleby, 1195.

St. Joe-Clearwater region: Calkins and Jones, 164.

southeastern: Schultz and Richards, 1030.

Illinois: Eckel, 342.

Tallula and Springfield quadrangles: Shaw and Savage, 1042.

Indiana : Eckel, 342.

Iowa : Eckel, 342.

Kansas: Eckel, 342.

Kentucky : Eckel, 342. northeastern : Munn, 838 .

Manitoba : Bryce, 131 ; Malcolm, 741. coal fields: Dowling, 329 .

Dawson Bay : MacLean, 736 .

Winnipeg to Malachi : Collins, 246.

Maryland: Eckel, 342.

Devonian: Swartz, 1132.

Mexico, Zacatecas district: Villafaña, 1214.

Michigan : Fckel, 342.

Arenac County: Gregory, 442.

Mississippi : Eckel, 342.

Missouri : Eckel, 342.

Montana, coal fields : Stebinger, 1105.

Glacier National Park, Pleistocene deposits: Alden and Stebinger, 11.

Helena region : Knopf, 626.

Philipsburg quadrangle: Emmons and Calkins, 360.

southwestern: Pardee, 881 .

Nevada, Antelope district: Schrader, 1021.

New Brunswick, coal fields: Dowling: 329.

Moncton, Albert mines, Young, 1347.

St. John area : Young, 1347.

New Jersey, mineral industries: Twitchell, 1173.

New York: Eckel, 342.

Mohawk Valley: Roorbach, 998.

Niagara quadrangle: Kindle and Taylor, 619 . 
Geologic maps-Continued.

New York: North Creek quadrangle: Miller, 822.

St. Lawrence and Jefferson counties: McDonald, 728.

North America, ice age: Chamberlin, 189.

North Carolina, Ellijay quadrangle: La Forge and Phalen, 643.

North Dakota: Leonard, 678.

Nova Scotia: Malcolm, 740 .

Arisaig area: 'Twenhofel, 1172.

Cape Breton Island, George River area : Young, 1347.

Coal fields: Dowling, 329. -

New Glasgow area: Young, 1347.

Oldham gold district: Faribault, 367.

Sydney coal field: Young, 1347.

Union-Riversdale area : Young, 1347.

Windsor-1Horton area: Bell, 63.

Ohio: Eckel, 342.

Oklahoma: Eckel, 342 ; Snider, 1077.

Arbuckle Mountains: Buttram, 154.

Ontario, Bucke to Lake Nipigon: Collins, 246.

Cobalt area: Miller, 817.

Collingwood: Parks, 890 .

Credit River area : Parks, 888.

Gowganda mining division: Collins, 244.

Grenville sheet: Adams, 7.

Hagersville district: Stauffer, 1102.

Haliburton-Bancroft area: Adams and Barlow, 8.

Hamilton area : Parks, 887.

Lake Nipigon to Lake Abitibi : Burrows, 145.

Lake of the Woods: Parsons, 891.

Loon Lake district: Parsons, 892.

Madoc area: Knight, 625.

Malachi to Richan: Collins, 246.

Manitoulin Island: Foerste, 378; Williams, 1293.

Massey mine area: Coleman, 233.

Parry Island: Walker, 1229.

Port Colborne region: Stauffer, 1103.

Queensboro pyrite area: Knight, 625.

Rainy Lake, Bears Passage: Uglow, 1.183.

Rainy River district, Golden Star mine: Uglow, 1183.

Richan to Bucke: Collins, 246.

southwestern, moraines: Taylor, 1151.

Steeprock Lake district: Uglow, 1183.

Sudbury region: Coleman, 231.

Sudbury - Cobalt - Porcupine region : Gibson, 400 ; Miller, 814.

Toronto region: Coleman, 236 ; Taylor, 1150.

Whiskey Lake area : Colęman, 232.
Geologic maps-Continued.

Pennsylvanla: Eckel, 342.

Barnesboro and Patton quadrangles : Campbell et ar., 169.

Boyertown region: Bliss, 81.

Panther Creek Valley: Richards, 975.

Triassic area: :Wherry, 1266.

Quebec, asbestos district: Harvie, 466.

Bathurst: Young, 1347.

Bic : Young, 1347.

Chaleur Bay: Clarke, 213.

Côte St. Pierre: stansfield, 1101.

Dalhousie : Clarke, 213.

Dominion mine: Stansfield, 1101.

Emerald mine: Stansfield, 1101.

Gaspe Peninsula : Clarke, .213.

Greenville sheet: Adams, 7.

Harricanaw region: Bancroft, 36 .

Levis : Raymond, 946.

Monteregian Fllls: Adams, 7.

Montmorency Falls: Raymond, 946.

Montreal: Adams, 7.

Mount Johnson : Adams, 7 .

Nellis mine, Cantley: Stansfield, 1101.

Quebec and vicinity: Raymond, 946 .

Rivière du Loup: Young, 1347.

Scaumenac Bay: Clarke, 213.

Walker mine: Stansfield, 1101.

Saskatchewan: Bryce, 131; Malcolm, 74.1.

coal fields: Dowling, 329.

Tennessee: Eckel, 342.

Ellijay quadrangle: La Forge, and Phalen, 643.

I'exas : Eckel, 342.

Wichita region: Gordon, 416.

United States, coal fields: Campbell, 168.

Utah, San Francisco region: Butler, 147.

Virginia: IEckel, 342.

Arvonia slate belt: Taber, 1143.

Arvonia-New Canton area: Taber, 1141.

Fauquier-Culpeper counties: Watson and Cline, 1244.

Holston Valley, Saltville area : Stose, 1127.

middle western: Watson and Cline, 1243.

Washington, Covada district: Weaver, 1251.

south central : Waring, 1233.

West Virginia : Eckel, 342.

Cabell, Wayne, and Lincoln counties: Krebs and Teets, 640.

Wyoming, oil fields: Trumbull, 1170.

Geologic thermometer: Johnston and Niggli, 566.

Geologic time.

General: Schuchert, 1027 ; Wrigbt, 1344.

Metẹor dụst: Lane, 653 , 
Geologic time--Continued.

Niagara Falls and gorge: Spencer, 1091.

Pleistocene: Fairchild, 366; Upham, 1204.

Geological reports, illustrations: Ridgway, 980 .

Geological surveys. See Surveys.

Geomorphogeny. See Physiographic.

Geomorphology. See Physiographic.

Geophysics.

Feldspars, melting phenomena: Bowen, 95.

Figh pressures, effects: Johnston and Adams, 565.

Lava maculæ: Hobbs, 508.

\section{Georgia.}

Economic.

Ellijay quadrangle: La Forge and Phalen, 643.

Gold : McCallie, 713.

Halloysite: Watkins, 1239.

Mineral springs: McCallie, 712.

Ocher deposits: McCallie, 714.

Slates, green: Maynard, 782 .

Physiographic.

Ellijay quadrangle: La Forge and Phalen, 643.

Stratigraphic.

Ellijay quadrangle: La Forge and Phalen, 643 .

Paleontology.

Pliocene Mollusca: Dall, 277.

Mineralogy.

Meteorite, Pauiding County: Watson, 1242.

Underground water.

Mineral springs: McCallie, 712 .

Geothermal data: Darton, 286.

Glacial erosion: Davis, 292.

Glacial geology.

General: Manson, 743 ; Taylor, 1151.

Field work: Leverett, 682.

Iowan drift: Leverett, 687.

Keewatin and Labrador glaciation areas: Upham, 1206

Lake Iroquois: Coleman, 235.

Map of North America during great ice age: Chamberlin, 189.

Niagara gorge and Great Lakes history: Taylor, 1152.

Pleistocene ice sheet, felds of outflow: Upham, 1203.

Pleistocene mollusks, significance : Shimek, 1044.

Pleistocene succession, Wisconsin : Weidman, 1260

Alaska, Copper River basin: Tarr and Martin, 1146.

Alleghany Valley erosion: Williams, 1286.

British Columbia, Vancouver Island : Clapp, 199.

California, Sierra Nevada Mountains : Manson, 743 ,
Glacial geology-Continued.

Cordillera, forty-ninth parallel: Daly, 278.

Great Lakes region: Leverett, 684; Taylor, 1148.

Idaho, Cordilleran ice sheet: Stewart, 1115.

Iowa, Iowa City, post-Kiansan glaciation: Leighton, 674.

south from Des Moines: 'Tilton, 1158.

Kansas: Todd, 1163

Wisconsin deposits: Todd, 1164.

Minnesota : Upham, 1204.

Sangamon interglacial stage: Upham, 1205 .

Montana, Glacier National Park: Al den and Stebinger, 11.

New Hampshire, Mount Washington: Gold thwait, 415.

White Mountains: Goldthwait, 410, 411.

New York: Fairchild, 366

Crown Point, glacial potholes: Barker, 40

interglacial deposits : Baker, 24.

Niagara quadrangle: Kindle and Taylor, 619 .

Ohio, Bellevue quadrangle: Carney, 180.

Ontario, Algonquin beach: Jóhnston, 568.

Patricia district: Tyrrell, 1175.

Patrician glacier: Tyrrell, 1177.

southwestern, moraines: Taylor, 1151.

Toronto: Coleman, 234, 236.

Toronto region: Taylor, 1150.

Toronto, moraines: Taylor, 11.50 .

Pennsylvania: Hice, 494

glacial border, recent date: Wright, 1345.

Luzerne County : Darton, 283

South Dakota, Wisconsin drift-plain : Carman, 179.

Washington, Cordilleran . ice sheet: Stewart, 1115.

Puget Sound region: Bretz, 101.

Wisconsin, Pleistocene succession : Weidman, 1260 .

Glacial lakes. See also Beaches; Shore lines; Terraces.

Great Lakes region: Leverett, 683, 684 ; Taylor, 1148, 1.149.

Lake Agassiz: Leverett, 683,685 .

Lake Iroquois: Coleman, 236.

New York: Fairchild, 366.

Niagara quadrangle: Kindle and Taylor, 619

Obio, Bellevue quadrangle: Carney, 180.

Ontario, sonthwestern: Taylor, 1151

Time relations in Great Lakes region: Leverett, 684 .

Washington, Puget Sound region: Bretz, 101 
Glacial period. See Glacial geology.

Glacier National Park: Martin, 757.

\section{Glaciers.}

Alaska : Tarr, 1145.

Allen glacier: Martin, 758 .

Glacier Bay: Martin, 754 .

Prince William Sound: Martin, 759. and Kenai Peninsula: Grant and Higgins, 434.

Yakutat Bay region: Martin, 754.

Greenland, variations, 1912: Mercanton, 786 .

United States, variations, 1912: Reld, 965.

Variations: Reid, 962-964

Washington, Mount Rainier: Matthes, 770 .

Glass sand.

Oklahoma: Buttram, 154.

Gold.

General.

Associated minerals: Nicholson, 847.

Fineness of gold: Knopf, 629; Smith, 1073.

Manganese in superficial alteration : Eddingfield, 345 .

Metallic precipitants: Palmer and Bastin, 878.

Persistence of ore in depth: Maclaren, 735 .

Enrichment: Brokaw, 105.

Alaska, Circle quadrangle: Prindle, 930.

Chisana district: Cairnes, 162.

Chitina Valley : Mottit, 828.

Ellamar district: Capps and Johnson, 178

Fairbanks district: Smith, 1.069, 1073.

Falrbanks quadrangle: Prindle, 929. Innoko-Iditarod region: Eakin, 337.

Kodiak and neighboring islands : Martin, 750 .

Koyukuk-Chandalar region: Maddren, 739.

McKinley Iake district: Chapin, 196.

Noatak-Kobuk region : Smith, 1068.

Nome and Grand Central quadrangles: Moffit, 827.

Rampart quadrangle: Dakin, 335.

Ruby district: Eakin, 336.

Seward Peninsula: Smith, 1070.

Willow Creek district: Smith, 1074.

Yentna district: Capps, 177.

Yukon-Tanana region: Ellsworth and Davenport, 347 .

Arizona, Oro Blanco district: Milton, 823.

placers: Carter, 182

British Columbia, Atlin district: Atlin District Board of Trade, 20.

Atlin district: Cairnes, 158

Tulameen district: Camsell, 170.
Gold-Continued.

Californla, Trinity County, Carrville district: MacDonald, 722 .

Colorado, Monarch and Tomichi districts : Crawford, 266.

Mosquito district, Park County, Moore, 834.

Georgia: McCallie, 713.

Ellijay quadrangle: La Forge and Phalen, 643.

Idaho, Buffalo Hump district: Flagg, 373.

Custer County: Umpleby, 1195.

Elk City district: Flagg, 372.

Lemhi County: Umpleby, 1198.

Loon Creek district: Umpleby, 11.94

southeastern : Schultz and.Richards, 1030 .

Montana, Georgetown district: Billingsley, 75 .

Helena region: Knopf, 626.

Philipsburg quadrangle: Emmons and Calkins, 360 .

Nevada, Antelope district: Schrader, 1021.

Kennedy district: Klopstock, 621 .

Nova Scotia: Brown, 124; Lawson, 664 ; Malcolm, 740.

gold-bearing series: Faribault, 367 .

Ontario : Bell, 62 ; Lett, 681 ; Tyırell, 1176.

Kirkland Lake district: Hore, 525; Spearman, 1084

Porcupine district: Burrows, 144 ; Dulieux, 333; Hore, 521, 526.

West Shining Tree area: Stewart, 1.117 .

Whiskey Lake area: Coleman, 232.

United States: McCaskey, 71.7.

Utah, Grand County, La Sal Mountains: Fill, 500.

Paria, in Shinarump clay: Lawson, 663.

San Francisco district: Butler, 147.

Virginia, James River basin: Taber. 1141.

Yukon, Klondike area: Cairnes, 1.59; MacLean, 737: Tyrrell, 1174.

Giand Canyon of Colorado: Davis, 296

Grand Canyon, angular amphitheaters: Keyes, 607

Grand Central quadrangle, Alaska: Moffit, 827.

Granites, origin : Lane, 656.

Graphical plot for plagioclase feldspars: Wright, 1340.

\section{Graphite.}

New Mexico, Raton district: Lee, 669 .

New York: Newland, 844.

Pennsylvania : Miller, 810.

Quebec, Dominion mine: Stansfield, 1101.

Walker mine : Stansfield, 1101.

United States: Bastin, 55. 
Gravel.

New York: Newland, 844.

Pennsylvania, anthracite region: Darton, 282.

United States: Stone, 1119.

Great Basin ranges, deformation: Baker, 23.

\section{Great Lakes.}

General: Spencer, 1089, 1093.

\section{Greenland.}

Dynamic and structural.

Glaciers, variations, 1912 : Mercanton, 786.

Gulf of St. Lawrence, origin: Clarke, 210.

Gypsum.

New Brunswick, Hillsborough : Kramm, 636.

New York: Newland, 844.

Oklahoma : Snider, 1078, 1081

United States: Stone, 1119.

Utah, San Rafael Swell: Lupton, 711. Virginia, southwestern: Stose, 1127.

\section{Halloysite.}

Georgia : Watkins, 1239.

\section{Hawailan Islands.}

Dynamic and structural.

Kilauea : Curtis, 272; Day and Shepherd, 300 .

ejectamenta: Perret, 906.

floating islands of Halemaumau : Perret, 903.

formations in crater: Perret, 907.

lava: Brun, 129.

lava fields: Heim, 477.

lava fountains: Perret, 902.

lava lake: Perret, 904.

subsidence phenomena: Perret, 905.

Magmatic gases, Kilauea: Day and Shepherd, 301.

Volcanic research at Kilauea, 1911: Perret, 909.

Volcano observatory: Wood, 1320.

Physiographic.

Kilauea, lava fields: Heim, 477.

Petrology.

Lavas : Cross, 269.

Holothuroidea.

Cambrian: Clark, 205.

Eldonia, restoration: Clark, 204.

Fypacrosaurus: Brown, 120.

Ice age, cause: Upham, 1204.

Ice ages, cause: Humphreys, 540 .

Ice ages (ancient).

General: Manson, 743; Wilson, 1303.

Climatic changes due to volcanic dust: Humphreys, 540.

Huronian : Coleman, 241.

Ice beds.

Alberta, Nome, and Grand Central quadrangles, Alaska : Moffit, 827.

Ice caves: Miller, 809
Idaho.

Economic.

Buffalo Hump district: Flagg, 373.

Coal at Horseshoe Bend and Jerusalem Valley: Bowen, 91.

Cceur d'Alene district: Ingalsbe, $\mathbf{5 4 5}$.

origin of lead, zinc, and silver deposits: Hershey, 483

enrichment: Shannon, 1039.

Elk City district, Idaho County : Flagg, 372 .

Lead-silver deposits, Gilmore, Lemhi County : Nichols, 846.

Lemhi County: Umpleby, 1193.

Lignite, Goose Creek district, Cassia County : Bowen, 92.

Loon Creek district: Umpleby, 1194.

Mica deposits, Latah County: Sterrett, 1106.

Mining industry, 1912: Bell, 63.

Ore deposits, Custer County: Umpleby, 1195.

Phosphate deposits: Jones, 569.

St. Joe-Clearwater region: Calkins and Jones, 164.

Southeastern Idaho: Schultz and Richards, 1030.

Dynamic and structural.

Bannock fault: Richards and Mansfield, 974 .

Cone in cone structure in coal : Woodruff, 1326.

Southeast Idaho, structural features: Richards and Mansfield, 973.

Physiographic.

Erosion surface, Eocene: Umpleby, 1196.

Lemhi County : Umpleby, 1193.

stratigraphic.

Cordillera, forty-ninth parallel: Daly, 278.

Cordilleran ice sheet: Stewart, 1115.

Custer County: Umpleby, 1195.

Goose Creek district, Cassia County: Bowen, 92.

Horseshoe Bend and Jerusalem Valley : Bowen, 91.

Lemhi County : Umpleby, 1193.

St. Joe-Clearwater region: Calkins and Jones, 164.

Southeastern Idaho: Schultz and Richards, 1030.

Paleontology.

Ordovician graptolites, Wood River valley: Blackwelder, 76.

Petrology.

Cordillera, forty-ninth parallel: Daly, 278.

Mineralogy.

Custerite : Umpleby et al., 1197.

Plattnerite, Cœur d'Alene: Shannon, 1040. 
Igneous and volcanic rocks, See also Intrusions; Magmas.

General: Grabau, 425 ; Iddings, 544. Alkaline rocks, origin: Smyth, 1076. Classification, quantitative: Cross, 268.

Crystallization, order of : Bowen, 95 . Crystallization, order of : Zieglec, 1352.

Petrogenesis: Daly, 281.

Quantitative mineralogical classification of gradational rocks : Lincoln, 690 .

Textbook: Finlay, 371.

Alaska, Circle quadrangle: Mertie, 802 .

Fairbanks quadrangle: Prindle, 929.

Noatak-Kobuk region: Smith, 1068.

Nome and Grand Central quadrangles: Moffit, 827 .

Seward Peninsula: Smith, 1070.

Arizona, San Franciscan field: Robinson, 987.

Sulphur Spring Valley: Meinzer and Kelton, 785 .

Arkansas, southwest-central: Miser, 826.

British Columbia, Atlin district: Calrnes, 158.

coast region : Bancroft, 35.

Cordilleran formations: Daly, 279.

Vancouver Island: Clapp, 199.

California, Trinity County, Carrville district ; MacDonald, 722.

Cordillera, forty-ninth parallel: Daly, 278.

Colorado, Creede district: Emmons and Larsen, 362.

Monarch and Tomichi districts : Crawford, 266.

Rabbit Ears region: Grout et al., 450.

Costa Rica : Alfaro, 12.

Georgia, Ellijay quadrangle: La Forge and Phalen, 643.

Iduho, Custer County: Umpleby, 1195.

Lembi County: Umpleby, 1193.

Loon Creek district: Umpleby, 1194.

St. Joe-Clearwater region: Calkins and Jones, 164.

Mortana, Helena region: Knopf, 626.

Philipsburg quadrangle: Emmons and Calkins, 360.

Nevada, Antelope district: Schrader, 1021.

New Hampshire, Hanover district: Merritt, 801.

New Mexico, Raton Mesa region: Mertie, 803.

New York: Kemp, 588.

Northumberland volcanic plug: Cusining, 273.

Nova Scotia: Malcolm, 740 .

Panama Canal Zone: MacDonald, 723.

Quebec, asbestos district: Farvie, 466.

Laurentian highlands: Wilson, 1305.

Monteregfan Fills: Adams, 7.
Igneous and volcanic rocks-Continued.

Utah, Grand County, La Sal Mountains: Hill, 500.

San Francisco district: Butler, 147. Virginia: Watson and Taber, 1247.

Amherst-Nelson counties: Watson and 'Taber, 1249.

central western: Watson and Cline, 1243.

James River basin : Taber, 1141.

Washington, Covada district: Weaver, 1251.

Igneous intrusion. See Intrusion.

Illinois.

Economic.

Coal : Bement, 65.

Springfield quadrangle: Shaw and Savage, 1042.

Tallula quadrangle: Shaw and Savage, 1042.

Physiographic.

Jo Daviess County, partly dissected plains : Trowbridge, 1169.

Springfield quadrangle: Shaw and Savage, 1042.

Tallula quadrangle: Shaw and Savage, 1042.

Stratigraphic.

Alexandrian series: Silvage, 1.007, 1008.

Springfield quadrangle: Shaw and Savage, 1042.

Tallula quadrangle: Shaw and Savage, 1042.

Paleontology.

Alexandrian serles, fauna: Savage, 1.008.

Amphibia, Mazon Creek: Moodie, 831.

Arthropods, Devonian: Savage, 1.009.

Indiana.

Physiographic.

Wabash Valley : Dryel, 330.

Stratigraphic.

Kokomo limestone age: Kindle, 618.

Unconformity at base of Onondaga : Kindle, 61.6.

Paleontology.

Eurypterids, Kokomo limestone, age : Kindle, 618 .

Kokomo fauna: Kindle, 618.

Onychaster, Crawfordsville: Sollas, 1082.

Insecta.

General: Cockerell, 223.

Colorado, Florissant: Cockerell, 220, 221, 226 ; Wickhnm, 1282.

Anthomyid fly : Cockerell, 217.

Asilld fly : Cockerell, 225.

Coleoptera: Wickham, 1281.

Isoptera : Cockerell, 216.

Mydaid fly: Cockerell, 2

Odonata : Calvert, 165.

Fhryganea: Cockerell, 222. 
Intrusions. See also Dikes; Igneous and volcanic rocks; Laccoliths; Magmas.

General: Uglow, 1184.

Colorado, Monarch and Tomichi districts : Crawford, 266.

Cordillera, forty-ninth parallel: Daly, 278.

Palisade diabase, intrusion temperature: Sosman and Merwin, 1083.

Invertebrata (general). See also Anthozoa ; Brachiopoda ; Crustacea ; Echinodermata ; Foraminifera ; Insecta ; Mollusca ; Problematica ; Spongida; Vermes.

Alexandrian series, Illinois and Missouri: Savage, 1008.

Ohio, Conemaugh fauna: Mark, 747.

Virginia, Walker Mountain, Bays fauna: Grabau, 427.

Iowa.

General.

Bibliography of geology and mining: Keyes, 601 .

\section{Stratigraphic.}

Bethany limestone: Tilton, 1159.

Cretaceous sequence: Keyes, 609.

Devonian formations: Thomas, 1155.

Devonian succession: Keyes, 610.

Devonian-Carboniferous unconformity : Keyes, 604.

Glaciation, post-Kansan, Iowa City : Leighton, 674.

Loess, so-called: Gow, 422.

Pleistocene section south of Des Moines : Tilton, 1158.

'Tertiary Riverside sands: Keyes, 611.

Paleontology.

Trilobites, Maquoketa beds, Fayette County : Slocum, 1057.

Iridium.

United States: Day, 302.

Iron.

General.

Appalachian interbedded ores, genesis : Earle, 339.

Brown iron ores as cavity fillings: Eckel, 343.

Chromic iron ore, United States: Diller, 320.

Future of iron industry: Kemp, 587.

Titaniferous magnetites: Brunton, 130 ; Newland, 845.

microstructure: Singewald, 1054, 1056.

British Columbia, Granby Bay : Mc. Connell, 719.

Colorado, Cebolla district: Singewald, 1055.

Georgia, Ellijay quadrangle: La Forge and Phalen, 643.

Lake Superior region: Engelbach, 364. Michigan iron ranges: MaDonald, 729 .
Iron-Continued.

Minnesota: Winchell, 1310.

Cuyuna district, South Range: Zapffe and Barrows, 1351.

Cuyuna Range: Kellogg, 585.

Montana, Elkhorn deposits: Knopf, 628.

Nevada, Barth: Jones, 570.

New Brunswick, Austin Brook district: Lindeman, 692.

New York: Newland, 844. northern: McDonald, 728.

Nova Scotia: Woodman, 1323.

Ontario: Lindeman, 693.

Moose Mountain iron range: Coleman, 237 ; Lindeman; 694.

Quebec: Dulieux, 332.

Bathurst mines: Young; 1347.

Tennessee: Gordon, 417. . . :

Clinton ore: MacFarlane, 730 .

eastern: Burchard; 135.

Texas: Linton, 701.

United States: Burchard, 136.

Virginia : Springer, 1096.

Jointing.

Laws of: Grammer, 433.

Jurassic.

Stratigrapluy.

Alaska, Noatak-Kobuk region: Smith, 1068.

Alberta : Malcolm, $\mathbf{7 4 1 .}$

Rocky Mountains : Allan, 13.

British Columbia, Atlin district : Cairnes, 158.

coast region: Bancroft, 35 .

Elko to Kootenay Lake: Schofield, - 1020 .

Skeena River district: McConnell, 719 .

Tulameen district: Camsell, 170.

Vancouver Island: Clapp, 199.

West Kootenay and Boundary districts: LeRoy, 680.

California, Monterey County: Davis, 289.

Santa Lucia Mountains: Davis, 289

Colorado, Rabbit Ears region: Grout et $a l ., 450$.

Cuba, western: Torre, 1166.

Idaho, southeastern : Schultz and Richards, 1.030

Mexico, Mixteca Alta: Wieland, 1.283.

Montana, Felena region: Knopf, 626.

Philipsburg quadrangle: Emmons and Calkins, 360.

Paleontology.

California, Santa Lucia Mountains : Davis, 289.

Mexico, Mixteca Alta, Liassic flora : Wieland, 1283.

Mollusca, boreal types in Mexico: Burckhardt, 138. 
Kansas.

General.

Paleoliths: Winchell, 1311.

Economic.

Petroleum and natural gas, southeast-

Stratigraphic. ern Kansas : Gould, 421.

"Moraines": : Todd, 1163.

Pleistocene crustal movements in Mississippi Valley: Todd, 1.161.

Wisconsin deposits : Todd, 1164.

Paleontology.

Castoroides skull : Martin, 752.

Cretaceous fish, Portheus molossus: Woodward, 1327.

Ctenoptychius, Permian: Martin, 753 Enchodus, teleostean: Green, 439.

Pleistocene molluscan fauna, Phillips

County: Hanna and Johnston, 462.

Vertebrate footprints, Permian: Moodie, 830 .

Mineralogy.

Meteorite, Cullison, Pratt County : Merrill, 798.

Kaolin.

Appalachians, southern: Watts, 1250 .

Kennedy mining district, Nevada: Klopstock, 621 .

\section{Kentucky.}

Economic.

Coal, Harlan fleld : Peck and Sampson, 895.

Menifee gas field: Munn, 838 .

Ragland oil field: Munn, 838.

Dynamic and structural.

Mammoth Cave: Whitbeck, 1269.

Stratigraphic.

Unconformity at base of Onondaga:

Paleontology. Kindle, 616.

Fishes, Paleozoic: Hussakof, 542.

Palæoniscid fishes, Boyle County : Eastman, 341 .

Keweenawan fault: Lane, 657.

Keweenawan series, age: Lane, 655.

Iaccoliths.

General: Daly, 281.

Form of: Paige, 872 .

Lakes, glacial. See Glacial lakes.

Lambdotherlum : Osborn, \$64.

Lamellibranchiata. See Pelecypoda.

Land classification: Heroy, 482; Smith et al., 1064.

\section{Landslides.}

General: Howe, 531.

Panama Canal Zone, Culebra cut: Cornish, 257 ; MacDonald, 720, $721,727$.

Lapis lazuli.

Callfornia : Surr, 1131.

Laurentian : Lane, 652.
Lava.

Arizona, San Franciscan field: Robinson, 987.

Hawail, Kllauea: Brun, 129; Cross, 269 ; Heim, 477.

Iead.

Arizona, Bisbee district: Notman, 853.

British Columbia, Lynn Creek district : Emmens, 351.

Colorado, Creede district: Emmons and Larsen, 362.

Monarch and Tomichi districts : Crawford, 266.

Mosquito district, London mine : Moore, 834.

Rico district: Ritter, 984.

Idaho, Cœur d'Alene district: Hershey, 483; Ingalsbe, 545.

Custer County: Umpleby, 1195.

Lemhi County: Nichols, 846 ; Umpleby, 1193.

Loon Creek district: Umpleby, 1194.

Missouri, Joplin district: Wright, 1333 .

southwestern : Heap, 476.

Montana, Elkhorn deposits: Knopf, 628.

Helena region: Knopf, $626,627$.

Nevada, Yellow Pine district: Hill, 500.

New Mexico, Grant County: Larsh, 658.

United States: Siebenthal, 1.053.

Utah, San Francisco district: Butler, 147

Lignite. Sce also Coal.

North Dakota, Williston lignite field: Herald, 481.

Lime.

United States: Stone, 1119.

Limestono.

General.

I.imestone, pre-Silurian, origin : Daly, 278.

Californta: Eckel, 342.

Kentucky : Isckel, 342.

Maryland : Eckel, 342.

Oklahoma: Eckel, 342.

Pennsylvania: Eckel, 342.

York Valley : Jandorf, 551.

I'ennessee: Eckel, 342.

Texas: Eckel, 342.

Virginia: Iickel, 342.

West Virginia: Eckel, 342.

Lithium.

South Dakota, Black Hills: Ziegler, 1358.

Louisiana.

Dynamic and structural.

Mud lumps, Mississippi Delta: Shaw, 1041.

Paleontology.

Pliocene Mollusca: Dall, 277.

l.ower Silurian. See Ordovician. 
McDonald deep well, Pennsylvania: White, 1276.

\section{Mackenzie.}

General.

Coppermine country: Tyrrell, 1178.

Magmas. See also Intrusions.

General: Daly, 281.

Crystallization, order of : Bowen, 95 ; Ziegler, 1352.

Gases, magmatic: Day and Shepherd, 301 .

Lava maculæ: Hobbs, 508.

Palisade diabase, intrusion temperature: Sosman and Merwin, 1083.

Arizona, Silverbell : Stewart, 1113.

Cordillera, forty-ninth parallel: Daly, 278.

\section{Magnesite.}

United States: Yale and Gale, 1346.

Maine.

General.

Bibliography : Babb, 21.

\section{Economic.}

Clay, Portland region: Katz, 579.

\section{Stratigraphic.}

Eastport quadrangle: Bastin and Williams, 56.

Fortland and Casco Bay quadrangles :

\section{Paleontology.} Katz, 578 .

Eastport quadrangle, Silurian fauna: Williams, 1290.

Silurian, Edmunds and Pembroke formations, Washington County: Williams, 1289.

\section{Mammalia.}

General: Scott, 1032.

Alabama, Zeuglodon: Gidley, 403.

Alaska, Equus skull : Hay, 472.

Asphalt group of fossil skeletons: Matthew, 779 .

Bathyopsis, Wind River uintathere: Osborn, 865 .

Bison: Hay, 473.

Camel, Pleistocene, Rancho La Brea, California: Merriam, 789.

Camelops: Hay, 474.

Castoroides: Martin, 752.

Cervalces antler from Toronto interglacial: Bensley, 66 .

Cuba, Pleistocene: Torre, 1167.

Eomoropus: Osborn, 563 .

Equidæ: Hay, 471.

Horns, phylogeny and ontogeny : Osborn, 866 .

Horses, Mohave Desert, California : Merriam, 794

Rancho La Brea, California: Merriam, 793 .

Tertiary, Mohave Desert, California: Merriam, 795 .

Walker Lake, Utah : Merriam, 794.

Yale collection: Lutl, 709 .

Maryland, eland: Gidley, 402.
Mammalia-Continued.

Merycodus horn, Miocene, Mohave, California: Merriam, 790.

Mylodon, Nebraska : Allen, 15.

Nothrotherium and Megalonyx from Fleistocene of California : Stock, 1118.

Orindan fauna, California: Merriam, 792.

Pleistocene, Maryland: Gidley, 404.

Siestan fauna, California: Merriam, 792.

Skull measurements: Osborn, 867.

Tapir, Cenozoic, Pacific coast region: Merriam, 788.

Tennessee, mastodon remains: Anon., 1354.

Tephrocyon: Merrîam, 791.

Titanotheres, Lambdotherium, Eotitanops: Osborn, 864 .

Tupaiidæ and Notharctus: Gregory, 447.

Zalambdodont insectivore, Eocene, New Mexico: Matthew, 776.

Mammoth Cave: Whitbeck, 1269.

Man, fossil.

British Columbia, Savona, skeleton in silt: Moncton, 829 .

Glacial man: Lull, 708.

Kansas paleoliths: Winchell, 1311.

Manganese.

Georgia, Ellijay quadrangle: La Forge and Phalen, 643.

United States : Hewett, 492.

Manitoba.

General: Bryce, 131.

Dynamic and structural.

Pseudobrecciation in Ordoviclan limestones: Wallace, 1230.

Stratigraphic.

General: Collins and Camsell, 248; Dowling, 326 ; Malcolm, 741.

Devonian, Snake Island and Lake Winnipegosis: MacLean, 736.

Hayes River region, Ordovician deposits : Tyrrell, 1175.

Ordovician: Wallace, 1230.

and Silurian, Stony Mountain and Stonewall: MacLean, 736 .

Winnipeg to Cochrane: Collins and Wilson, 249.

Winnipeg to Malacht: Collins, 246.

Paleontology.

Hayes River region, Ordovician depos. its: Tyrrell, 1175.

Ordovician fossils, Shamattawa River : Parks, 884.

Map making. See Cartography.

Maps See Geologic maps.

Marble.

Alaskan, Ketchikan and Wrangell districts : Burchard, 134

Georgia, Ellijay quadrangle: La Forge and Phalen, 643. 
Martinique.

General: Guppy, 451.

Paleontology.

Mollusca, Miocene : Cossmann, 259.

Maryland.

Stratigraphic.

Devonian, Lower: Schuchert et al., 1029 ; Swartz, 1132.

correlation: Swartz, 1133.

historical review and bibliography: Prosser, 933.

paleogeography: Schuchert, 1023.

Devonian, Middle: Prosser et al., 937.

Devonian, Upper : Barrell, 45 ; Prosser and. Swartz, 936.

correlation : Swartz, 1135.

local sections: Swartz, 1136.

Paleontology.

Devonian: Md. G. S., 764 .

Brachlopoda: Schuchert and Maynard, 1028.

Brachiopoda, Pelecypoda, Gastropoda, Cephalopoda, Trilobita : Prosser and Kindle, 935 .

Bryozoa: Ulrich and Bassler, 1190, 1191.

Cephalopoda: Ohern and Maynard, 858.

Cœlenterata : Prosser, 934; Swartz, 1134.

Crinoidea: Ohern, 857.

Cystoidea: Schuchert, 1024.

Gastropoda: Ohern and Maynard, 858.

Ostracoda: Ulrich and Bassler, 1190.

Pelecypodal : Ohern and Maynard, 858.

Pisces : Swartz, 1137.

Trilobita: Ohern and Maynard, 858.

Vermes: Kindle, 614 ; Ohern, 857.

Eland: Gidley, 402.

Pleistocene cave deposit, near Cumberland: Gidley, 404.

Massachusetts.

Dynamic and structural.

Frarvard seismographic station, fourth annual report: Woodworth, 1328.

stratigraphic.

Blue Hills area: Warren, 1.234 .

petrology.

Alkali-granites and porphyries of Quincy and the Blue Hills: Warren, 1.234 .

\section{Mastodon.}

Tennessee: Anon., 1354.

Medusae. See Hydrozoa.

Meetings. See Associations.

Mercury. See Quicksilver.

\section{Metamorphism.}

General: Bastin, 52 ; Grabau, 425.

Grenville limestone: Julien, $\mathbf{5 7 5}$.

Hydrothermal alteration: Uglow, 1185.

Pre-Cambrian, Ontario: Coleman, 239.

Pre-Cambrian schists: Adams, 4.
Metamorphism-Continued.

General-Continued.

Principles . underlying metamorphic processes : Johnston and Niggli, 566.

Pseudo-diorite: Keith, 584.

Silicate zones at contacts: Uglow, 1184.

Montana, Phllipsburg quadrangle: Emmons and Çalkins, 360.

Utah, San Francisco district: Butler, 147.

Virginia, James Ríver basín: Taber, 1141.

Metasomatism in downward sulphide enrichment: Bastin, 52.

Meteorites.

General.

Factors in exchange value: Foote, 382.

Minor constituents : Merrill, 799.

Canyon Diablo irons: Keyes, 613 .

Carthage, Tennessee : Kaemmerer, 576, 577.

Cullison, Pratt County, Kansas : Merrill, 798.

Mount Morris, New York: Whitlock, 1278.

Paulding, Georgia: Watson, 1242.

Mexico.

General.

Coahuila: Haarman, 453.

Lower California: Bonillas and $\mathrm{Ur}$ bina, 84; Böse and Wittich, 86 ; Engerrand and Paredes, 365 ; Flores and Gonzalez, 376 ; Mexico, Inst. Geol., \$06.

Sierra de Santa Catarina, Mexico, D. F.: Waitz, 1.222.

Sierra Madre Oceldental, Durango: Villafaĩa, 1215.

Economic.

Cananea ore deposits, Sonora: Elsing, 349 .

Chihuahua: Paredes, 882.

Coal fields: Hill, 501; Schwarz, 1031.

Guanajuato, La Lu\% district: Spilsbury, 1094.

Guerrero, Bravos district: Flores, 375.

Juan Casiano oil field, Vera Cruz: Hornaday, 527.

Magistral district, .Talísco: Ordoñez, 860.

Petroleum fields, northeastern Mexico: White, 1275 .

Puebla, Sierra Magistral, copper deposits : Brinsmade, 103.

Santa Eulalia, Chihuahua: Brinker, 102.

Yesca, Tepic: Wattz and Hijar y Haro, 1223.

Dynamic and structural.

Earthquake, June 7, 1911: Miranda y Marron, 825.

Earthquakes, Guadalajara: Ordoñez, 859 . 
Mexico-Continued.

Stratigraphic.

Coahuila: Haarman, 453.

Cretaceous, Coabuila : Böse, 85.

Mixteca Alta, Jurassic: Wieland, 1283.

Post-Pliocene deposits, Papaloapam district: Wittich, 1315.

Paleontology.

Cretaceous faunas, Coahuila: Böse, 85 .

Liassic flora, Mixteca Alta: Wieland, 1.283.

Mollusca, boreal types in Jurassic:

Mineralogy. Burckhardt, 138.

Chihuahua: Wittich, 1316.

Coahuila, Sierra Mojada, Veta Rica mine: Van Horn, 1208.

Gypsum crystals, Chihuahua: Wittich and Pastor y Giraud, 1318.

Naica: Dégoutin, 305.

Minerals, crystallography: Ungemach, 11.98 .

Topaz: Wittich and Pastor y Giraud, 1317.

Underground water.

Zacatecas district: Villafaña, 1214.

Mica.

Colorado, Mesa County: Sterrett, 1106.

Idaho, Latah County: Sterrett, 1106.

New Mexico, Rio Arriba County: Sterrett, 1106 .

Ontario, Kingston district: Baker, 28.

Quebec, Nellis mine, Cantley: Stansfield, 1101.

United States: Sterrett, 1107.

\section{Michigan.}

General.

Boring, salt well : Fry, 391.

Progress of survey: Allen and Ruthven, 16.

Economic.

Arenac County: Gregory, 442.

Physiographic.

General: Lane, 654.

St. Clair and Detroit rivers region, drainage changes: Taylor, 1153.

\section{Stratigraphic.}

Arenac County: Gregory, 442.

Borings, Manistee region: Fry, 390.

Detroit River area : Nattress, 840.

Paleontology.

Organic remains in iron-bearing rocks: Cayeux, 187.

Postglacial Mollusca, Emmet County : Baker, 25.

Underground water.

Arenac County: Gregory, 442.

Mine waters.

Composition: Emmons, 358; Emmons and Harrington, 361 .

Mineral deposits: Lindgren, 698.

Mineral paints.

United States: Hill, 501.

Mineral resources (general). See Economio under the names of States.
Mineral waters.

Georgia: McCallie, 712.

New York: Newland, 844.

United States: Matson, 767 .

Mineralogy (general). See also Meteorites; Technique. For regional, see names of States. For particular minerals, see list p. 163.

Albite, composition: Foote and Bradley, 380 .

Colloid minerals, nomenclature: Wherry, 1267.

Color plate photographs: Levison, 6S3.

Crystals, change in optical properties with temperature: Kraus and Youngs, 639.

Determination of minerals of nonmetallic luster: Moses, 836.

Determination of soil-forming minerals: McCaughey and Fry, 718 .

Determinative, with tables: Lewis, 689.

Feldspars: Rogers, 990.

plagioclase, melting phenomena: Bowen, 95.

Glauberite, variations of optic angle of axis: Kraus, 637.

Graphical 'plot for plagioclase feldspars: Wright, 1340.

Indices of crystal faces: Rogers, 993.

Lens for interference figures: Johannsen, 559 .

Mineral formulas: Schaller, 1013.

Nomenclature: Rogers, 991.

Pseudomorphs of limonite after marcasite: North, 851.

Quartz, change in angles with temperature: Wright, 1341.

Refractive indices, strengite: Schaller, 1017.

Silica minerals, stability relations : Fenner, 369.

Solid solution: Foote and Bradley, 381 . Sperrylite, artificial: Wells, 1261.

Minerals described. Sce list p. 163.

Minnesota.

Economic.

Iron ores, Cuyuna district, South Range: Zapffe and Barrows, 1351.

Cuyuna Range : Kellogg, 585.

Iron ranges: Winchell, 1310.

Stratigraplic.

Mesabi rocks, age: Winchell, 131.2.

Sangamon interglacial stage: Upham, 1204,1205

Paleontology.

Organic remains in iron-bearing rocks : Cayeux, 187.

Miocene. See Tertiary.

Miscellaneous. See also Addresses.

Geological reports, illustrations : Ridgway, 980 .

Geology and engineering: Purdue, 941. 
Mississippl.

Paleontology.

Petrified forest: Brown, 123.

Mississippian formations, cooperative investigation of: De Wolf, 313.

Mississippian. See Carboniferous.

\section{Missouri.}

Economic.

Lead and zinc ores, Joplin district: Wright, 1333.

Miami district: Heap, 476.

Mineral resources: Buehler, 132.

Dynamic and structural.

New Madrid earthquake: Sampson, 1003.

Stratigraphic.

Alexandrian serles: Savage, 1007, 1008.

Columbia section: Branson, 100.

Devonian-Carboniferous unconformity : Keyes, 604.

Paleontology.

Alexandrian series, fauna: Savage, 1008.

Devonian fishes: Branson, 99.

Scyphocrinus slab: Bassler, 51.

Mollusca. See also Cephalopoda; Gastropoda ; Felecypoda.

California, Eocene, Marysville Buttes: Dickerson, 314.

Jurassic: Davis, 289.

Cretaceous, Mexico, Coahuila : Böse, 85 .

Jurassic, boreal types in Mexico: Burckhardt, 138.

Maine, Silurian : Williams, 1289.

Panama, Gatun fauna: Brown and Pilsbry, 115.

Panama, Pleistocene: Brown and Pilsbry, 11.6.

Pleistocene, Kansas : Hanna and Johnston, 462 .

Pliocene, Constal Plain: Dall, 277.

South Dakota, interglacial: Baker, 26.

Molluscoidea. See Brachiopoda; Bryozoa.

\section{Molybdenite.}

British Columbia, 'Tulameen district: Citmsell, 170 .

Quebec, Turn Back Lake: Sweezey, 1140.

\section{Molybdenum.}

United States: Hess, 488.

Monarch and Tomichi districts, Colorado: Crawford; 266.

Monazite.

North Carolina: Fratt, 926 .

\section{Montana.}

Economic.

Butte, ore deposits: Graton, 436 ; Sales, 1001.

sulphide enrichment and chalcocite formation: Rogers, 992.

Butte mines, applied geology in : Linforth, 700 .

\section{Montana-Continued.}

Economic-Continued.

Coal fields: Stebinger, 1105.

Coal in Tertiary lake beds of southwestern Montana: Pardee, 881.

Copper, Butte: Weed, 1256.

Elkhorn ore deposits: Knopf, 628.

Georgetown, Southern Cross mine: Billingsley, 75 .

Helena region: Knopf, 626.

silver-lead deposits: Knopf, 627.

Little Sheep Mountain coal field, Dawson, Custer, and Rosebud counties: Roger's, 995.

Niter near Melrose: Rlchards, 972.

rhilipsburg quadrangle: Emmons and Calkins, 360

Phosphate, westèn Montana: Pardee, 880.

Southern Cross mine, Georgetown : Blllingsley, 75.

Dynamic and structural.

Fault, overthrust: Rogers, 997.

Stratigraphic.

Coal fields: Stebinger, 1105.

Cordillera, forty-ninth parallel: Daly, 278.

Glacier National Park, pre-Wisconsin glacial drift: Alden and Stebinger, 11.

Helena region: Knopf, 626.

Lebo shale member of Fort Union formation : Rogers, 996.

Little Sheep Mountain coal fleld, Dawson, Custer, and Rosebud counties : Rogers, 995.

P.hilipsburg quadrangle: Emmons and Calkins, 360.

Tertiary lake beds of southwestern Montana : Pardee, 881.

Petrology.

Coldillera, forty-ninth parallel: Daly, 278.

Mineralogy.

Butte district: Bard and Gidel, 39.

Philipsburg quadrangle: Emmons and Calkins, 360.

Vanadiferous agirites from Libby: Larsen and Hunt, 659.

Monterey series in California : Louderback. 703.

Moraines.

New York, Niagara quadrangle: Kindle and 'Taylor, 619.

Ontario, southwestern: 'Taylor, 1151.

Toronto region: Taylor, 1150.

Mottling of limestones: Wallace, 123n.

Mount Mazama: Martin, 756.

Mud lumps, Mississippi delta: Shaw, 1041.

Natural bridges.

Indiana, Parke County, Mansfield: Dryer, 330. 
Natural gas.

General: Westcott, 1264.

Outline of geology : Clapp, 202.

Alberta : Malcolm, 741.

Canada : Clapp and Huntley, 203.

Kansas, southeastern: Gould, 421.

Kentucky, Menifee field: Munn, 838.

New York: Newland, 844.

Oklahoma : Snider, 1077 ; Wood, 1321. eastern: Gould, 421.

Ohio, Oberlin field: Hubbard, 533.

Pittsfield : Burroughs, 141.

Pennsylvania, Barnesboro and Patton quadrangles: Campbell et al., 169.

Punxsutawney quadrangle: Ashley and Campbell, 19.

United States: Clapp, 202 ; Hill, 498.

West Virginia, Cabell, Wayne, and Lincoln counties: Krebs and Teets, 640 .

Marion, Monongaria, and Taylor counties: Hennen and Reger, 479.

Nebraska.

Paleontology.

Mylodon garmani : Alten, 15.

Ogmodirus martini, from Niobrara: Williston and Moodie, 1300.

\section{Nevada.}

Economic.

Alunite, Bovard : Schrader, 1022.

Antelope district: Schrader, 1021.

Barth iron ore deposit: Jones, 570.

Coaldale coal field, Esmeralda County : Hance, 460.

Ely district: Spencer, 1086.

Pioche, Prince Consolidated mine: Zalinski, 1349.

Prince Consolidated mines: Jessup, 557.

Gold deposits, Goldfield: Barnes and Byler, 42.

Iron-ore deposit, Barth : Jones, 570.

Kennedy mining district: Klopstock, 621.

Potash, Railroad Valley : Free, 388.

search for: Gale, 393.

Rochester district: Jones, 571.

Salines, Silver Peak Marsh : Dole, 323.

Zinc-lead deposits, Yellow Pine district: Hill, 500 .

Physiographic.

Alluvial fans: Lawson, 662.

Stratigraphic.

Antelope district: Schrader, 1021.

Paleontology.

Tephrocyon: Merriam, 791.

\section{Mineralogy.}

Gypsum and anhydrite, Ludwig mine, Lyon County: Rogers, 994.

Iodyrite, Tonopah, crystal form : Kraus and Cook, 638.

Triplite from eastern Nevada: Hess and Hunt, 490 .

\section{New Brunswick.}

Economic.

Austin Brook iron-bearing district : Lindeman, 692 .

Coal fields: Gray, 438.

Hillsborough gypsum deposit: Kramm, 636.

Physiographic.

General: Ganong, 395 ; Goldthwait, 411.

Stratigraphic.

General: Young, 1347.

Carboniferous: Stopes, 1122.

Grand Falls area: Young, 1347.

Hillsborough gypsum deposit: Kramm, 636.

Moncton, Albert mines: Young, 1347.

St. John area : Young, 1347.

Southern New Brunswick: Matthew, 772 .

Paleontology.

Fern ledges, St. Jonn : Stopes, 1121.

Lepidostrobus: Wilson, 1307.

Plants, fossil : Holden, 514.

Silurian flora: Matthew, $\mathbf{7 7 2}$.

Mineralogy.

Topaz, crystal habit: Ellsworth, 348.

Newfoundland.

Economic.

Coal: Howley, 532.

Stratigraphic.

Geological map : Canada G. S., 176.

New Hamphire.

Physiographic.

Glacial cirques near Mount Washington: Goldthwait, 410, 415 .

Lost River, history : Sayles, 1010.

White Mountains, Presidential Range: Goldthwait, 411.

Stratigraphic.

Hanover district: Merritt, 801.

Littleton area : Lahee, 644.

Paleontology.

Littleton area: Lahee, 644.

New Jersey.

General.

Report State geologist, 1912, Kümmel, 642.

Soils, Sussex area : Blair and Jenning, 80.

Economic.

Mineral industry, 1912: 'Twitchell, 1173.

Watchung Mountain, copper: Bond, 82.

Dynamic and structurat.

Palisade diabase, intrusion temperature: Sosman and Merwin, 1083.

Stratigraphic.

Upper Devonian : Barrell, 45.

Paleontology.

Cretaceous Pityoxyla from Cliffwood: Holden, 513, 
New Jersey-Continued.

Paleontology-Continued.

Cretaceous sponge: Shimer and Powers, 1046.

Pbytosaur, Palisades: Huene, 538. Mineralogy.

Hodgkinsonite, Franklin Furnace: Palache and Schaller, 876.

Princeton minerals: Hawkins, 470.

Willemite: Palache and Graham, 875.

New Madrid earthquake: Sampson, 1003.

\section{New Mexico.}

General.

Carbonaceous deposit near Putnam : Foster, 385.

Economic.

Cerrillos coal field, Sinta Fe County: Lee, 670 .

Copper deposits, Bent: Ball, 31.

Graphite, Raton district: Lee, 669 .

Lead-vanadium ores, Grant County : Larsh, 658.

Mica deposits, Rio Arriba County : Sterrett, 1106.

Tres Hermanas district: Wade, 1.219.

Vanadium, Sierra de los Caballos: Hess, 484

Physiographic.

Gallina quadrangle: Case, 183.

stratigraphic.

Cerrillos coal. field, Santa Fe County: Lee, 670 .

Jemez Platean: Kelly and Anspach, 586.

Raton Mesa region: Knowlton, 632. Igneous rocks: Mertie, 803.

Red beds: Case, 184.

Rio Grande region: Henderson, 478.

Paleontology.

Permo-Carboniferous vertebrates: Case et al., 1.85.

Zalambdodont insectivore, Eocene : Matthew, 776 .

Underground water.

Jemez Plateau, springs: Kelly and Anspach, 586 .

\section{New York.}

General.

Hudson River, fault control : Berkey, 69.

Report director science: Clarke, 209.

Report State geologist, 1912: Clarke, 209.

Economic.

Garnet deposits, Warren County: Miller, 821 .

Mineral resources, 1912 : Newland, 844

Mining and quarry industry, 1912: Newland, 844.

Northern New York: McDonald, 728.

Dynamic and structural.

Glacial potholes, Crown Point: Barker, 40.

Submarine slide at Trenton Falls: Hahn, 457.
New York-Continued.

Physiographic.

Mohawk Valley, fault-block topography, Roorbach, 998.

Niagara Falls: Spencer, 1091.

Niagara Falls and gorge : 'Taylor, 11.49.

Niagara quadrangle: Kindle and TayIor, 619

Northern New York: Spencer, 1088.

Paleozoic, southern. Adirondacks: Miller, 820.

Stratigraphic.

Adirondacks, southern, Paleozoic physiography: Miller, 820 .

Cataract formation: Schuchert, 1025.

Interglacial deposits: Baker, 24.

Nlagara quadrangle: Kindle and 'Iaylor, 619 .

Pleistocene : Fairchild, 366.

Pre-Cambrian : IKemp, 588.

Saratoga County, Northumberland volcanic plug: Cushing, 273.

Uncomformity at base of Onondaga:

Kindle, 616.

Unconformity at Catskill: Chadwick, 1.88.

Upper Devonian : Barrell, 45.

J'aleontology.

Tropidoleptus zones, Devonlan: Williams, 1288.

Petrology.

Adirondack basic intrusives: Miller, 822.

Saratoga County, Northumberland vol-

Mineralogy. canic plug: Cushing, 273.

Mount Morris meteorite: Whitlock, 1278.

Niagara Falls.

General: Grabau, 429; Kindle and Taylor, 619 ; Spencer, 1091 ; Taglor, 1149.

Bibliography: Haskell, 467.

Niagara quadrangle, New York: Kindle and Taylor, 619.

Nickel.

Idaho, Lemhi County, Umpleby, 11.93.

Ontario, Sudbury area: Coleman, 231, 237.

United States: Hess, 488.

Niter.

Montana, Melrose : Richards, 972.

Noatak-Kobuk region, Alaska : Smith, 1068.

Nome quadrangle, Alaska: Moffit, 827.

Nomenclature. See also Stratigraphic.

Algonkian : Leith, .677.

Alluvial formations: Lawson, 662 .

Blocks and segments : Udden, 1181.

Faulting: Reid et al., 967.

Minerals, colloid: Wherry, 1267.

Ore, definition: Peele, 896.

Paleontology : Matthew, $\mathbf{7 7 5}$.

Physiographic forms: Davis, 295.

Pre-Cambrian: Woodworth et $a l,, 1331$. 
Nomenclature-Continued.

Rock types, Virginia: Watson and Taber, 1248.

Segment and segmentation: Adams, 9.

Trilobita : Raymond, 949.

Cryptolithus versus Trinucleus: Raymond, 950.

\section{North Carolina.}

General.

Geological history of western North Carolina : Pratt, 927.

Report, State geologist, 1911-12 : Pratt, 925.

\section{Economic:}

Copper deposits: Thompson, 1157.

Monazite : Pratt, 926.

Pyrophyllite: Hafer, 455.

\section{Stratigraphic.}

Ellijay quadrangle: La Forge and Phalen, 643.

Mineralogy.

Monazite: Pratt, 926.

\section{North Dakota.}

\section{Economic.}

Williston lignite field, Williams County: Herald, 481.

\section{Stratigraphic.}

Geologic map: Leonard, 678.

Notharctus: Gregory, 447.

\section{Nova Scotia.}

\section{Economic.}

Coal, Cape Breton fields: Anon., 1357.

Coal fields: Gray, 438.

Gold and coal deposits : Lawson, 664 .

Gold deposits: Brown, 124.

Gold fields: Malcolm, $\mathbf{7 4 0}$.

Gold-bearing series : Faribault, 367 .

Iron ores: Woodman, 1323.

Oldham gold district: Faribault, 367 .

Mineral deposits, St. Mary Bay: Wilson, 1301.

Sydney coal fields, Cape Breton: Hudson, 537.

Tungsten : Hills, 506.

Dynamic and structural.

Earthquake, Cape Breton: McIntosh, 734.

Physiographic.

General: Goldthwait, 411.

Cape Breton Island, forelands of Bras d'Or Lakes: Woodman, 1322.

Shoreline, Cascumpeque Harbor, Prince Edward Island: Johnson, 562.

Windsor-Horton: Bell, 63.

\section{stratigraphic.}

General: Young,.1347.

Arisaig area: Twenhofel, 1172 .

George River area, Cape Breton Island: Young, 1347.

Gold fields: Malcolm, 740.

Gold-bearing series: Faribault, 367.

Joggins section: Bell, 63.

Riversdale-Union group, Truro: Hyde, 543 ; Young, 1347.

Nova Scotia-Continued.

Stratigraphic-Continued.

Sydney coal field: Hyde, 543; Young, 1347.

Windsor-Horton : Bell, 63.

Paleontology.

Horton flora : White, 1271.

Sydney coal field flora: White, 1271. Mineralogy.

Opal, Lunenburg County : Piers, 920.

Ocean, pre-Cambrian: Daly, 280.

Ocher.

Georgia: McCallie, 714.

Ohio.

General.

Findlay borings, temperature: Johnston, 561 .

Economic.

Berea sandstone : Burroughs, 140.

Coal fields: Burroughs, 142.

Gas, Oberlin : Hubbard, 533.

Oil, Oberlin : Hubbard, 533.

Petroleum and natural gas, Oberlin field : Hubbard, $\mathbf{5 3 3}$.

Pittsfield oil field: Burroughs, 141.

Physiographic.

Bellevue quadrangle, proglacial lake shorelines: Carney, 180

Glaciation, early : Hubbard, 534.

Moot's Run area, Licking County, drainage changes: Nixon and Tight, 850 .

\section{Stratigraphic.}

Conemaugh formation: Condit, 251.

Findlay, deep borings: Condit, 252.

Huron and Cleveland shales: Prosser, 932.

Unconformity at base of Onondaga : Kindle, 616 .

Paleontology.

Conemaugh fauna: Mark, 747.

Oll. See Petroleum.

Oil shales.

New Brunswick, Albert mines: Kramm, 636

\section{Oklahoma}

Economic.

Coal, McAlester field : Brown, 125.

Glass sands: Buttram, 154.

Gypsum and salt: Snider, 1078.

Gypsum deposits: Snider, 1081.

Natural gas: Snider, 1077.

Oil and gas development: Wood, 1321

Petroleum : Snider, 1077.

Petroleum and natural gas, eastern Oklahoma: Gould, 421.

Petroleum in red beds: Gould, 420.

Rock asphalts : Snider, 1079, 1080.

Paleontology.

Fishes, Caney shales: Eastman, 341.

Oligocene. See Tertiary. 
Ontario.

General

Patricia district: Tyrell, 1175.

Whiskey Lake area: Coleman, 232.

Economic.

Clay deposits: Baker, 29.

Cobalt district: Colvocoresses, 250 ; Hore, 522, 524; Miller, 815, 817,818 .

Gold, occurrence of : Bell, 62 ; Lett, 681 ; Tyrrell, 1176.

Forcupine district: Hore, 521.

Gowganda mining division: Collins, 244.

Kingston mineral deposits: Baker, 28.

Kirkland Lake gold district: Hore, $5.5 ;$ Spearman, 1084.

Lake Superior silver deposits: Miller, 817.

Madoc area, Hastings County : Kuight, 625.

Magnetite along Central Ontario Rallway : Lindeman, 693.

Massey copper mine area: Coleman, 233.

Moose Mountain iron range: Coleman, 237 ; Lindeman, 694.

Phosphate and feldspar deposits: Schmid, 1018.

Porcupine area: Burrows, 144; Dulieux, 333.

Porcupine gold deposits, origin: Hore, 526.

Report Bureau of Mines, 1913: Gibson, $400^{-}$.

Silver, Cobalt district: Hore, 523.

South Lorrain : Tyrrell, 1179.

Sudbury area: Coleman, 231, 237.

Sudbury - Cobalt - Polcupine region: Miller, 814 ; Miller and Knight, 819.

Timiskaming cobalt-nickel and silver deposits: Miller, 817.

West Shining Tree gold area: Stewart, 1117.

Dynamic and structurul.

Earthquake of April 2s, 1913: Klotz, 622.

Metamorphism in pre-Cambrian : Coleman, 239

Physiographic.

Iroquois beach : Coleman, 235.

Niagara Falls: Spencer, 1091.

Niagara Falls and gorge: Taylor, 1149.

Stratigraphic.

General: Collins and Camsell, 248.

Algonquin beach, glacial phenomena : Johnston, 561.

Classification, Archean : Coleman, 240 .

Cataract formation: Schuchert, 1025.

Cobalt area: Miller, 815, 817.

Cobalt series, Timiskaming region: Wilson, 1303.

Glacial phenomena, Toronto: Coleman, 234.

Gold districts: Tyrrell, 1176.

$3 \$ 416^{\circ}-$ Bull. $584-1.4-10$
Ontario-Contiuued.

Strutigraphic-Continued.

Gowganda area: Collins, 244.

Hagersville district: Stauffer, 1102.

Faliburton-Bancroft area: Adams and Barlow, 8.

Familton formation at Thedtord : Willians, 1292.

Iron Spur district: Uglow, 1183.

Lake Nipigon to Lake Abitibi: Burrows, 145.

Lake of the Woods region: Parsons, 891,892

Loon Lake district, pre-Cambrian : Parsons, 892.

Lowville limestone, Lake Simcoe district: Johnston, 561.

Madoc area, Hastings County : Knight, 625.

Malachi to Lake Nipigon: Collins, 246. Manitoulin Island: Foerste, 377.

Mohawkian, Manitoulin Island and northeast: Foerste, 378.

Moraines, north of Toronto: Taylor, 1150.

southwestern Ontario: Taylor, 1151.

Muskoka lakes region: Lindsey, 694.

Ordovician, Credit River: Parks, 889.

Ottawa: Raymond, 952.

Paleozoic section, Familton: Farks, 887.

Patrician glacier, Tyrrell, 1177.

Porcupine area: Burrows, 144.

Port Arthur district, pre-Cambrian : Parsons, 892.

Port Colborne region: Stauffer, 1103.

Port Coldwell area, nepheline and alkali syenites: Barlow, 41.

Pre-Cambrian : Collins, 247.

Parry Island: Walker, 1229.

Rainy Lake, Coutchlching series: Uglow, 1183.

Silurian: Williams, 1291.

Credit River : Parks, 888.

Manitoulin Island: Williams, 1293.

Steeprock Lake distrlct: Uglow, 1183.

Sudbury area: Coleman, 231., 237.

Sudbury-Cobalt-1'orcupine region: Miller, 814 .

Superficlal deposits near Ottawa : Keele and Johnston, 582.

Temagami area : Miller, 816.

Toronto: Coleman, 236.

moraines: 'l'aylor, 1150.

Unconformity at base of Onondaga : Kindle, 616.

Western Peninsula: r'arks, 890.

West Shining Tree gold area: Stewart, 1117.

Winnipeg to Cochrane: Collins and Wilson, 249.

Paleontology.

Brachlopod, Oxoplecia: Wilson, 1302.

Cervalces antler from Toronto interglacial: Bensley, 66. 
Ontario-Continued.

Paleontology - Continued.

Guelph, Onondaga, and Hamilton faunas: Parks, 886.

Hagersville district, Oriskany and Onondaga faunas: Stauffer, 1102.

Hamilton fauna at Thedford : Williams, 1292.

Silurian fossils, Fawn and Severn rivers: Parks, 884.

Petrology.

Haliburton-Bancroft area : Adams and Barlow, 8.

Port Coldwell area, nepheline and alMineralogy. kali syenites: Barlow, 41.

Oolite.

Cobalt area: Miller, 817.

Formation of : Vaughan, 1210, 1211.

Origin : Brown, 124

Ordovician.

Stratigraphy.

General: Schuchert, 1027.

Correlation of beds: Grabau, 427 .

Subdivisions: Grabau, 423.

Alaska, Fairbanks quadrangle: Prindle, 929.

Alberta, Robson Peak district: Walcott, 1225.

Arctic regions, Ellesmere Land: Holtedabl, 518.

British Columbia, Cordilleran formations: Daly, 279.

Robson Peak district : Walcott, 1225.

Rocky Mountains: Allan, 13.

Colorado, Monarch and Tomichi districts: Crawford, 266.

Idaho, Lemhi County: Umpleby, 1193.

Manitoba: Malcolm, 741 .

Hayes River region: Tyrrell, 1175.

Stony Mountain : MacLean, 736.

New Brunswick, St. John area: Young, 1347.

New York, southern Adirondacks: Miller, 820.

Trenton Falls: Hahn, 457.

Nova Scotia, Arisaig area: Twenhofel, 1172.

Ohio, Findlay borings: Condit, 252.

Ontario, Collingwood: Parks, 890.

correlation: Raymond, 958.

Credit River area: Parks, 889.

Hamilton area: Parks, 887.

Lake Simcoe district, Lowville limestone: Johnston, 561.

Manitoulin Island : Foerste, 377, 378.

Toronto: Coleman, 234, 236.

Quebec: Young, 1347.

correlation : Raymond, 958.

Gaspe Peninsula : Clarke, 213.

Montreal: Raymond, 952.

Ottawa : Raymond, 952.

Quebec and vicinity : Raymond, 946; Stansfield, 1101.

Richmond formations: Foerste, 379.
Ordovician-Continued.

Stratigraphy-Continued.

Saskatchewan: Malcolm, 741.

Silurian-Ordovician boundary: Ulrich, 1187.

Tennessee, eastern: Burchard, 135. southeastern: Ulrich and Butts, 1192.

Utah, Randolph quadrangle: Richardson, 977 .

San Francisco district: Butler, 147.

Wasatch Mountains: Hintze, 507.

Vermont, Sudbury, Ordovician outlier : Dale, 276.

Taconic Mountains: Keith, 583.

Virginia, Buckingham County: Taber, 1143.

James River basin: Taber, 1141.

Wyoming, Bighorn dolomite: Blackwelder, 78 .

\section{Paleontology.}

Arctic regions, Ellesmere Land: Holtedahl, 518.

Asaphidæ, Canada: Raymond, 955.

Ceraurinus: Barton, 49.

Ceraurus, revision: Raymond and Barton, 959 .

Cy.clocystoides : Raymond, 953 .

Idaho, Wood River valley: Blackwelder, 76.

Iowa, Fayette County : Slocum, 1057.

Manitoba, Shamattawa River: Parks, 884

Ontario, Ottawa, brachiopod: Wilson, 1302.

Toronto : Coleman, 234.

Tetradium, Canada : Raymond, 956.

Trilobites, Canadian : Raymond, 954.

Walker Mountain, Virginia, Bays fauna: Grabau, 427.

Ore deposits, origin. For ore deposits in general, see Economic (general).

General: Collins, 243; Emmons and Larsen, 363 ; Lindgren, 698.

Artificial vein formation, Telluride, Colorado: Kemp, 593.

Brown iron ores as cavity fillings : Eckel, 343.

Chalcocite, origin: MacCallum, 712.

Chalcocite enrichment: Spencer, 1087.

Contact zones: Kemp, 594.

Depth of ore deposits : Kemp, 596.

Depth of enrichment: Emmons, 359.

Electrochemical activity between solutions and ores: Wells, 1262.

Enrichment : Brokaw, 105; Graton, 435; Palmer and Bastin, S78.

Cœur d'Alene district, Idaho: Shannon, 1039.

in silver: Bastin, 53.

Exodus of ore deposits : Bancroft, 33.

Gel ores: Krusch, 641.

Ground-water : Kemp, 592.

Hydrothermal alteration: Uglow, 1185. 
Ore deposits, origin-Continued.

General-Continued.

Joints, influence on location of ore shoots: Bond, 82.

Manganese in superficial alteration: Eddingfield, 345.

Metasomatism in downward sulphide enrichment: Bastin, 52.

Mine waters and hot springs: Emmons and Harrington, 361.

Ore bodies at Cripple Creek: Colburn, 230 .

Ore deposits: Emmons, 352.

influence of depth: Kemp, 596.

Persistence of ore in depth: Maclaren, 735 ; Storms, 1123 ; Winchell, 1309.

Precipitation of gold and silver by minerals: Palmer and Bastin, S77.

Replacement, nature of: Stevens, 1109.

Replacement deposits, Cripple Creek district, Colorado: Colburn, 229.

Silicate zones: Stewart, 1115.

Sulphide enrichment: Emmons, 358 ; Grout, 449; Tolman, 1165; Whitman, 1279

upward, Butte, Montana: Rogers, 992.

Synthesis of pyrite: Whitman, 1279 .

Ultimate source of metals: Stevens, 1108.

Water in veins: Kemp, 595; Rickard, 979 .

Colemanite deposits, California: Gale, 392.

Colorado, Leadville : Rose, 999.

Monarch and Tomichi districts : Crawford, 266.

Wagon Wheel Gap, mineral deposits : Emmons and Larsen, 363.

Copper, disseminated replacement deposits: Botsford, 89 ; Clifford, 215.

Montana, Butte district: Bard and Gidel, 39 ; Sales, 1001.

sulphide ores, microscopic study: Graton and Murdoch, 437.

Virginia, James River basin: Taber, 1141.

Garnets, New York : Miller, 821.

Gold; general : Palmer and Bastin, 878.

Montana, Georgetown district: Billingsley, 75 .

Nevada, Goldfield: Batnes and Byler, 42.

Nova Scotia: Faribault, 367 .

Ontario, Porcupine district: Hore, 521, 526.

Virginia, James River basin: Taber, 1141.
Ore deposits, origin-Continued.

Iron, Appalachian ores: Earle, 339.

Nevada, Barth: Jones, 570.

Tennessee : Gordon, 417.

Lead, Idaho, Cœur d'Alene district: Hershey, 483.

Montana, Elkhorn deposits: Knnopf, 628.

Georgetown, Southern Cross mine: Billingsley, 75.

Nickel,'Sudbury region, Ontario : Cole man, 231.

Pyrite, vadose synthesis: Whitman, 1279.

Silver, enrichment: Cooke, 254

general : Palmer and Bastin, 878.

Idaho, Cœur d'Alene district: Hershey, 483.

Mexico, Guerrero, Blivos district: Flores, 375.

Ontario, Cobalt area : Miller, 81.5.

SuIphur, Colorado, Mineral County : Larsen and Hunter, 659.

Wyoming, Sunlight Basin : Hewett, 491.

Tourmalinic silver-lead deposits : Knopf, 627.

Utah, San Francisco district: Butler, 147.

Vanadium, Colorado: Hess, 486.

Zinc, Colorado, Leadville: Butler, $\mathbf{1 5 2}$.

Idaho, Cœur d'Alene district: Hershey, 483 .

Zircon, Virginia, Ashland: Watson and Hess, 1246.

Ore Shoots. See Economic geologs, and Ore deposits, origin.

Oregon,

Economic.

Clay deposits: Geijsbeek, 397.

Physiographic.

Crater Lake: Margerle, 746. .

Stratigraphic.

Tertiary, marine: Arnold and Hannibal, 18 .

Paleontology.

Birds of Oregon desert: Shufeldt, 1047 .

Desert region fauna: Shufeldt, 1050 .

Pleistocene avifauna: Shufeldt, 1048.

Tapir, Cenozoic: Merriam, 788.

Tephrocyon: Merriam, 791.

Orogeny.

Basin range structure: Keyes, 599; Paige, 871.

Deformation in Great Basin ranges: Baker, 23.

Oscillation. See Changes of level.

Ostracoda. Sec also Crustacea.

Maryland, Devonian, Upper: Clarke and Swart\%, 214.

Middle: Kindle, 614.

Lower : Ulrich and Bassler, 1190. 
Ostodolepis brevispinatus: Williston, 1295. Ozokerite.

Utah: Higgins, 497.

Paint. See Mineral paints.

\section{Paleobotany.}

Alabama, Tuscaloosa flora: Berry, 72.

Alaska, Cretaceous and Tertiary floras :

Hollick, 516.

Arizona, fossil forests: Knowlton, 634 .

British Columbia, Kettle River region: Penhallow, 898.

Colorado, Florissant, flowers and fruits: Cockerell, 218.

Coralline algæ in Ordovician dolomite : Blackwelder, $\mathbf{7 9}$.

Eocene flower, Tennessee : Berry, 72.

Fossilization in Paleozoic lycopods : Kindle, 615.

Forton flora, Carboniferous, Nova Scotia: White, 1271.

Lebephyllum, Tertiary, British Columbia: Wilson, 1306.

Lepidostrobus, New Brunswick: Wilson, 1307.

Lycopodiales, catalog of ; Jongmans, 573.

Mexico, Mixteca Alta, Liassic, flora : Wieland, 1283.

Mississippi, flora, petrified logs : Brown, 123.

New Brunswick: Holden, 514.

Carboniferous plants: Stopes, 1122.

fern ledges at St. John: Stopes, 1121.

Silurian flora: Matthew, 772.

New Jersey, Cliffwood, Cretaceous Pityoxyla: Holden, 513.

Nova Scotia, Sydney coal field flora: White, 1271.

Prince Edward Island: Holden, 514.

Quebec, Gaspe sandstone flora: White, 1271.

Roots in underclays of coals: White, 1272.

West Virginia: White, 1271.

Wyoming, Cretaceous Gleichenia Knowlton, 633.

\section{Paleoclimatology.}

General: Manson, 743.

Arctic fossil plants : Nathorst, 839.

Climatic changes: Huntingdon, 541.

Upper Devonian: Barrell, 45.

Volcanic dust: Humphreys, 540.

\section{Paleogeographic maps.}

Devonian: Schuchert, 1023.

close: Barrell, 45.

North America, Silurian and Ordovician: Grabau, 423.

Tertiary: Scott, 1032.

Paleogeography. See also Geologic history ; Paleoclimatology ; Paleogeographic maps.

General: Grabau, 430 ; Schuchert, 1027.

Devonian: Kindle, 616 ; Schuchert, 1027.
Paleogeography-Continued.

Devonian : Appalachian region : Swartz, 1132.

Geologic periods, delimitation: Schuchert, 1027.

New York, southern Adirondacks : Miller, 820.

Ordovician: Grabau, 427.

Paleozoic, Arctic regions: Frech, 386.

Quebec, Gaspe Peninsula: Clarke, 213.

Shelf-seas : Chamberlin, 192.

Silurian: Grabau, 427.

Tertiary: Scott, 1032.

Paleontology (general). See also the classes of animals and Paleobotany. For stratigraphic see the differ. ent systems. For regional see the names of States.

Cambrian Brachiopoda, habitat: Burling, 139.

Cambrian fauna, origin : Matthew, $\mathbf{7 7 3}$.

Correlation problems: Williams, 1290.

Fossilization in Paleozoic lycopods: Kindle, 615.

Fossils, first appearance: Daly, 278.

Nomenclature, laws of : Matthew, 775.

Phylogeny and correlation: Matthew, 774.

Pre-Cambrian ocean: Daly, 280.

Stereograms, use in paleobiology : Hudson, 535.

Stratigraphic work: Schuchert, 1026.

Textbook: Eastman, 340.

Paleozoic (undifferentiated).

Alaska, Circle quadrangle: Prindle, 930.

Fairbanks quadrangle: Prindle, 929.

Noatak-Kobuk region: Smith, 1068.

Nome and Grand Central quadrangles: Moffit, 827.

British Columbia, Atlin district: Cairnes, 158.

coast region: Bancroft, 35.

Maine, Portland and Casco Bay quadrangles: Katz, $\mathbf{5 7 8 .}$

Mexico, Coabuila : Haarman, 453.

Palladium.

United States: Day, 302.

Panama (including Canal Zone).

General: MacDonald, 725 .

Culebra cut: MacDonald, $\mathbf{7 2 0 .}$

Dynamic and structural.

Chiriqui Volcano: MacDonald, 724.

Gravitation waves in Culebra cut : Cornish, 257.

Slides: MacDonald, 721, 727.

Stratigraphic.

General: MacDonald, 721.

Geologic succession: MacDonald, 726.

Geology of the Isthmus: MacDonald, 723.

Paleontology.

Gatun fauna: Brown and Pilsbry, 115.

Mollusca, Miocene: Cossmann, 259.

Pleistocene: Brown and Pilsbry, 116. 
Pantylus, colylosaurian : Broom, 113.

Paragenesis of minerals.

Montana, Butte district: Bard and Gidel, 39 .

New Jersey, Princeton minerals : Hawkins, 470.

Patton quadrangle, Pennsylvania: Campbell et al., 169.

Peat.

Connecticut, New Haven: Davis, 288.

United States: Davis, 287.

Pelecypoda. Sec also Mollusca.

Maine, Silurian: Williams, 1289.

Maryland, Devonian: Clarke and Swartz, 214; Ohern and Maynard, 858; Prosser and Kindle, 935.

Unione fauna of Great Lakes: Walker, 1228.

Pelitic sediments and magmatic differentiation: Hobbs, 510.

Peneplains.

Criteria for peneplains: Trowbridge, 1169.

Peneplanation : Chamberlin, 194.

\section{Pennsylvania.}

General.

McDonald deep well: White, 1276.

Report Geological Survey, 1910-1912 : Pa. G. S., 899.

York County: Demming, 307.

Economic.

Anthracite, Panther Creek Valley: Richards, 975 .

Barnesboro quadrangle: Campbell et $a l ., 169$.

Copper, York County : Jandorf, 552.

Graphite: Miller, 810 .

Mineral production: Hice, 495.

Patton quadrangle: Campbell et al., 169.

Sand in anthracite basin: Darton, 282.

York Valley limestone belt: Jandorf, 55.1 .

Dynamic and structural.

Alleghany Valley erosion: Williams, 1286.

Cambrian and Ordovician rocks, origin: Brown, 124.

Paleozolc sediments, origin, Center County: Brown, 128.

Peridotite dike, Fayette and Green counties: Smith, 1066.

Punxsutawney, Curwensville, Houtzdale, Barnesboro, and Patton quadrangles, geologic structure : Asbley and Campbell, 19.

Physiographic.

Barnesboro quadrangle : Campbell et al., 169.

Buried valley, Susquehannil River, Luzerne County : Darton, 283.
Pennsylvania-Continued.

rhysiographic-Continued.

Drginage changes : Hice, 494 ; Ortman, 861.

Patton quadrangle: Campbell et al., 169.

Stratigraphic.

Alleghany Valley erosion: Williams, 1286.

Anthracite, northern, field: Darton, 284.

Anthracite fields, sections: Griffith, 448.

Barnesboro quadrangle: Campbell et el., 169.

Devonian, upper : Barrell, 45.

Glacial border, recent date: Wright, 1345.

McDonald deep well : White, 1276.

Fanther Creek Valley: Richards, 975.

Patton quadrangle: Campbell et al., 169.

Silurian limestone of Milesburg Gap, Bellefonte: Brown, 127.

Triassic: Wherry, 1266.

Paleontology.

Cambrian: Walcott, 1224.

Mineralogy.

Glaucophane, eastern P'ennsylvania : Bliss, 81.

Pennsylvanian. See Carboniferous.

rentremites. See Blastoldea.

Iermian. See Carboniferous.

Petrified forests of Arizona: Williams, 1287.

Petroleum.

General.

Accumulation: Munn, 838. .

Land classification: Smithet al.,1064.

Oil-bearing rocks, accumulation : Branner, 98.

Alberta : Malcolm, $\mathbf{7 4 1}$.

Arizona, Tonto Basin: Botsford, 88.

Barbados: Cunningham.Craig, 270.

California, anticlinal dome structure: Hager, 456.

Cat Canyon field: Smith, 1059.

Santa Susanna district: Johnson, 563.

southern: Prutzman, 938.

Canada: Clapp and Huntley, 203.

Colorado, De Beque field: Woodruff, 1325.

Kansas, southeastern : Gould, 421.

Kentucky, Ragland field: Munn, 838.

Mexico, northeastern: White, 1275 .

Vera Cruz, Juan Casiano fleld: Hornaday, 527.

New York: Newland, 844.

Ohio, Oberlin field: Hubbard, 533.

Pittsfield : Burroughs, 141.

Oklahoma : Gould, 420; Snider, 1077 ; Wood, 1321.

eastern: Gould, 4213.

United States: Day, 303 
Petroleum-Continued.

West Virginia, Cabell, Wayne, and Lin. coln counties: Krebs and 'Teets, 640.

Marion, Monongalia, and Taylor counties: Hennen and Reger, 479.

Wyoming: Trumbull, 1170.

Byron field: Roger's, 988 .

Cody : Hewett, 493.

Philosophy, etc.

Speculative nature of geology: Davis, 298.

Petrology (general). See also Igneous and volcanic rocks; Technique. For regional see names of states. For rocks described, see list, p. 164.

Analysis of rocks : Connor, 253.

Chemical composition as a criterion in identifying metamorphosed sediments: Bastin, 52.

Classification, quantitative, of igneous rocks : Cross, 268.

Classification on three coordinates: Winchell, 1308.

Components of rocks, relative volumes: Lincoln and Rietz, 691.

Composition, general : Hobbs, 508 .

Diorite produced by metamorphism : Keith, 584.

Feldspars, lenads, and zeolites: Washington, 1236.

Flow of rocks: Adams, 5.

Grain of rocks : Lane, 652.

Granites, origin : Lane, 656.

Graphical methods in microscopical petrography : Wright, 1339.

Graphical plot for plagioclase feldspars: Wright, 1340.

Index-ellipsoid in petrographic-microscopic work: Wright, 1335.

Lava maculæ: Hobbs, 508.

Microscopic petrography from the quan. titative standpoint: Wright, 1333.

Microscopic petrography: Wadsworth, 1220.

Oblique illumination in microscope work: Wright, 1334.

Petrogenesis: Daly, 281.

Petrographic description: Berkey, 67, 71.

Quantitative microscopic petrography: Wright, 1336.

Quantitative mineralogical classification of gradational rocks: Lincoln, 690 .

Quantitative physico-chemical investigations : Day, 299.

Sedimentary rocks: Rogers, 996.

Solubility of chemical constituents of rocks: Smyth, 1075 .

Phase rule: Johnston and Niggli, 566.

l'hilipsburg quadrangle, Montana: Emmons and Calkins, 360 .
Phosphate.

General.

Land classification: Smith et al., 1064.

Cuba, Batabano: Corral, 258.

Florida: Sellards, 1036.

origin : Sellards, 1037.

Idaho, southeastern: Jones, 569 ; Schultz and Richards, 1030.

Montana, western : Pardee, 880.

Ontario: Schmid, 1018.

Kingston district: Baker, 28.

Quebec: Schmid, 1018.

South Carolina: Waggaman, 1221.

Tennessee, Decatur County: Maynard, 783.

United States: Brown, 126; Phalen, 915.

Utah, northeastern: Jones, 569.

Wyoming, western: Jones, 569.

Physiographic (general). For regional see names of. States. See also Drainage changes.

General: Davis, 294; Grabau, 425.

Appalachians, newer and older: Emerson, 350 .

northern, post-Jurassic history : Barrell, 47.

Basin range structure: Keyes, 599 ; Butler, 147 ; Paige, 871.

Contraposed shorelines: Clapp, 198.

Criteria for peneplains: Trowbridge, 1169.

Enisled relief : Keyes, 608.

Great Basin ranges, deformation : Baker, 23.

Great Lake basins: Spencer, 1089.

Mesas, wind-graved: Keyes, 598.

- Nomenclature of surface forms on faulted structures: Davis, 295.

Original streams and desert-leveling: Keyes, 602.

Piedmont terraces of northern Appala. chians, origin : Barrell, 46 .

Textbook: Martin et al., 762.

Piedmont terraces of northern Appalachians, origin : Barrell, 46.

Pisces.

Brain structures : Eastman, 341.

Colorado, Ordovician (?): Cockerell, 219.

Ctenoptychius, Permian, Kansas : Martin, 753.

Devonian, Missouri : Branson, 99.

Enchodus, teleostean: Green, 439.

Helodont teeth, Alberta : Lambe, 648.

Kentucky, Devonian and Waverlyan: Hussakof, 542.

Maryland, Devonian, Upper : Swartz, 1137.

Paleozoic: Hussakof, 542.

Portheus molossus, from Cretaceous of Kansas: Woodward, 1327.

Scales: Cockerell, 195.

Sharks, California: Jordan and Beal, 574. 
Pitchblende.

Colorado, Gilpin County: Rickard, 978.

Pityoxyla from Cliffwood, New Jersey: Holden, 513.

Plecers. See also Gold.

General: Brooks, 106.

Alaska, Koyukuk-Chandalar region : Maddren, 739.

Seward Peninsula: Smith, 1070.

Plains.

Illinois, Joe Daviess County: Trowbridge, 1169.

Planetable mapping: Higgins, 496.

Platinum.

British Columbia, Tulameen district Camsell, 170.

United States: Day, 302.

Pleistocene. See Glacial geology; Quaternary.

Pliocene. Sce Tertiary.

Porcupine gold fields. Sce Ontarlo.

Portland cement. See Cement.

Potash.

General.

Exploration for, Nevada: Dole, 323.

Land classification: Smith et at., 1064.

Occurrence in bitterns: Phalen, 914. Occurrence in sillines: Turrentine, 1171.

California, Death Valley: Anon., 1356. Searles I.ake: Dolbear, 322.

Nevada, Rallroad Valley: Free, 388.

Timber Lake: Gale, 393.

United States: Phalen, 915.

Potholes:

New York, Crown Point : Barker, 40.

Pottsville-Allegheny boundary, interfor province : White, $\mathbf{1 2 7 3 .}$

\section{Pre-Cambrian.}

Stratigraphy.

General.

Classification: Miller, 813.

'limiskaming region: Collins, 247.

Metamorphism of pre-Cambrian schists: Adams, 4.

Nomenclature: Leith, 677; Woodworth et al., 1331.

Alberta, Rocky Mountains: Allan, 13.

British Columbia, Cordilleran formations: Daly, 279.

Elko to Kootenay Lake: Schofield, 1020.

West Kootenay and Boundary dlstricts: LeRoy, 680.

Colorado, Monarch and Tomichl districts : Crawford, 266

Rabbit Ears region: Grout et al., 450.

Cordillera, forty-ninth parallel: Daly, 278.

Georgia, Ellijay quadrangle: La Forge and Phulen, 643.
Pre-Cambrian-Continued.

Stratigraphy-Continued.

Idaho, Custer County : Umpleby, 1195.

St. Toe-Clearwater region: Calkins and Jones, 164.

Keweenawan fault: Lane, 657.

Keweenawan series, age: Lane, 655.

Lake Superior region: Collins, 247; Lawson, 665.

Laurentian : Lane, 652.

Manitoba: Collins and Wilson, 249.

Winnipeg to Malachi : Collins, 246.

Mesabi rocks, age: Winchell, 1312.

Montana, Helena region: Knopf, 626.

Philipsburg quadrangle: Emmons and Calkins, 360 .

New Brunswick, St. John area : Young, 1347

New York: Kemp, 588.

Adirondack region : Miller, 822.

Nova Scotia: Malcolm, 740.

Cape Breton Island, George River area: Young, 1347.

Gold-bearing series: Faribault, 367 :

Ontario: Coleman, 240; Collins and Wilson, 249 ; Tyrrell, 1176.

Cobalt area: Miller, $815,817$.

Cobalt series, 'Timiskaming region : Wilson, 1303.

Gowganda area: Collins, 244.

Haliburton-Bancroft area : Adams and Barlow, 8.

Iron Spur district: Uglow, 11.83.

Lake Nipigon to Lake Abitibi : Búrrows, 145.

Lake of the Woods: Parsons, 891, 892.

Loon Lake district: Parsons, 892.

Madoc area : Knight, 625.

Malachi to Lake Nipigon: Collins, 246.

Muskoka lakes region: Lindsey, 694.

northern : Coleman, 239.

Parry Island: Walker, 1229.

Patricia district: 'Tyrrell, 1175.

Porcupine area: Burrows, 1.44.

Port Arthur district: Parsons, 892

Steeprock Lake district: Uglow, 1183.

Sudbury area: Coleman, 231, 937.

Sudbury - Cobalt-Porcupine region : Miller, 814.

Sudbury, Cobalt, and Porcupine: Miller and Knight, 819.

Temagami area : Miller, 816 .

Timiskaming region, correlation: Collins, 247.

West Shining Tree area: Stewart, 1117.

Whiskey Lake area : Coleman, 232.

Quebec, asbestos district: Harvie, 460.

Harricanaw region : Bancroft, 36.

Laurentian highlands: Witson, 1305.

New Quebec territory: Denis, 309.

Ottawa district: Stansfield, 1100. 
Pre-Cambrian-Continued.

stratigraphy-Continued.

South Dikota, Black Hills: Paige, 870 .

Utah, Wasatch Mountains: Hintze, 507.

Virginia, James River basin: 'Taber, 1141.

Paleontology.

Lake Superior region, iron-bearing rocks : Cayeux, 187.

Precious stones. See also Diamonds; Sapphires; Turquoise.

United States: Sterrett, $\mathbf{1 1 0 7 .}$

Primates. See Mammalia.

Prince Edward Island.

Paleontology.

Plants, fossil : Holden, 514.

Protopalæaster narrawayi: Hudson, 536.

Protore: Ransome, 947.

Pseudomorphs.

Limonite after marcasite: North, 851.

Public lands, classification: Smith iet al., 1064.

Pyrite.

California, Plumas County: Bradley, 96.

New York: Newland, 844.

northern: McDonald, 728 .

Ontario, Queensboro area : Knight, 625.

United States: Phalen, 915.

Pyrophyllite.

North Carolina: Hafer, 455.

Pyrrhotite, Wisconsin, origin : Bagg, 22 .

Quartz.

United States: Katz, 580.

Quaternary. See also Glacial geology. stratigraphy.

Alaska, Noatak-Kobuk region: Smith, 1068.

Yentna district: Capps, 177.

Arizona, Sulphur Spring Valley : Meinzer and Kelton, $\mathbf{7 8 5}$.

British Columbia, coast region : Bancroft, 35 .

Vancouver Island: Clapp, 199.

Florida: Matson and Sanford, T6S.

Glacial period: Norton, 852.

Illinois, Tallula and Springfield quadrangles; Shaw and Savage, 1042.

Michigan, Arenac County: Gregory, 442.

New York: Fairchild, 366 .

Niagara quadrangle: Kindle and Taylor, 619.

North American and European drift deposits : Deeley, 304

North Dakota: Leonard, 678.

Ontario, Muskoka lakes region: Lindsey, 694

Toronto: Coleman, 236.

Toronto, moraines: Taylor, 1150.

Panama Canal Zone: MacDonald, 726.
Quaternary-Continued.

Strutigraphy-Continued.

J'exas, Wichita region: Gordon, 416.

Washington, Puget Sound region : Bret\%, 101.

Puleontology.

Alaska, Equus skull: Hay, 472.

California, Mohave Desert, horses : Merriam, 794.

Rancho La Brea deposits: Matthew, 779.

Rancho La Brea fauna: Merriam, 787.

horses: Merriam, 793.

camel: Merriam, 789.

San Pedro, Pleistocene Bathytoma: Rivers, 985.

tapir, Cenozoic: Merriam, 788.

Castoroides: Martin, $\mathbf{7 5 2}$.

Cuba : Brown, 118 ; Torre, 1167.

Kansas, Phillips County, Pleistocene Mollusca: Hanna and Johnston, 462.

Maryland, Cumberland, Pleistocene cave deposit: Gidley, 404.

Nebraska, Mylodon garmani : Allen, 15.

Ontario, Cervalces antler from Toronto interglacial: Bensley, 66.

Toronto: Coleman, 234.

Oregon, avifauna: Schufeldt, $\mathbf{1 0 4 8}$

tapir, Cenozoic: Merriam, 788.

Panama: Brown and Pilsbry, 116.

Pleistocene mollusks, significance: Shimek, 1044.

Postglacial Mollusca, Michigan and Wisconsin : Baker, 25.

South Dakota, interglacial mollusks: Baker, 26.

Utah, Walker Lake, horses: Merriam, 7.94 .

Quebec.

General.

Covey Hill, upper marine limit: Goldthwait, 414.

Eozoon, Côte St. Pierre: Stansfield, 1101.

IIarricanaw region: Bancroft, 36 .

Montreal, upper marine limit: Goldthwait, 413.

New Quebec: Denis, 309.

St. Jerome region: Victorin, 1213

Economic.

Asbestos deposits : Harvie, 466.

Bathurst mines: Young, 1347.

Building and ornamental stones: Parks, 885

Capelton copper deposits: Thompson, 1157.

Iron deposits: Dulieux, 332.

Mineral deposits, Ottawa district: Stansfield, 1101.

Mineral production, 1912 : Denis, 308.

Molybdenite, Turn Back Lake : Sweezey, 1140.

Phosphate and feldspar deposits : Schmid, 1018 . 
Guebec-Continued.

Uconomic-Continued.

Thetford-Danville asbestos deposits: Woolsey, 1832.

l'hysiographic.

General: Goldthwait, 411; Young et al., 1348.

Bic: Goldthwait, 411.

Chaleur Bay: Goldthwait, 411.

Quebec and vicinity: Goldthwait, 411.

Rivière du Loup: Goldthwait, 411.

Stratigraphic.

General: Young, 1347; Young et al., 1348 .

Asbestos deposits : Harvie, 466.

Black Cape Silurian section: Clarke, 213.

Cobalt series, Timiskaming region: Wilson, 1303.

Dalbousie region: Clarke, 213.

Gaspe Peninsula: Clarke, 213.

Laurentian highlands, banded gneisses: Wilson, 1305.

Morin anorthosite area: Adams, 6.

Monteregian Hills: Adams, 7.

Mount Johnson: Adams, 7 .

Ordovician, Montreal: Raymond, 952.

Quebec and vinicity: Raymond, 946.

St. Helen Island: Adams, 7.

raleontology.

Gaspe sandstone flora, Quebec: White, 1271.

Trilobite from Percé: Clarke, 211.

Petrology.

Monteregian Hills: Adams, 7.

Quicksilver.

United States: McCaskey, 717.

Radioactivity.

Colorado, Manitou springs: Shedd, 1043.

Radium.

General: Moore and Kithil, 835.

Colorado, Gilpin County : Rickard, 978.

Rare earths.

Idaho: Bell, 63.

Red beds : Case, 184 ; Henning, 480.

Relief maps.

Colorado, Cripple Creek district, topographic model: Byler and Davis, 157.

Replacement: Stevens, 1109.

Reptilia.

Angistorbinus, Triassic Phytosaur, Wyoming: Mehl, 784.

Aræoscelis and Casea, skulls: Williston, 1297.

Bolosaurus: Broom, 112.

Ceratopsia, Styracosaurus : Lambe, $\mathbf{6 5 1}$

Dinosaur, crested, Alberta: Brown, 117.

Hypacrosaurus, Edmonton Cretaceous : Brown, 120

Lacrimal and alisphenoid: Gregory, 446.
Reptilia-Continued

f.aurospondylus, Edmonton Cretaceous : Brown, 124.

Lizard from lermian of. Texas: Walliston, 1299.

Mandible, primitive structure: Williston, 1296.

New Mexico, Permo-Carboniferous: Case ct $a l$., 185 .

Ogmodirus martini, from Niobrara of Nebraska: Williston and Moodie, 1300.

Ostodolepis brevispinatus, Texas Permian : Williston, 1295.

Pantylus, colylosaurian: Broom, 113.

Pelycosaurian mandible: Williston, 1298.

Fermian, Texas: Williston, 1297.

Phytosaur, Palisades: Huene, 538.

Saurolophus, Edmonton Cretaceous : Brown, 119.

Skull elements, Permian Tetrapoda: Huene, 539.

Squamosal bone, mosasaurs: Broom, 111.

Trachodon, manus: Brown, 122; Lambe, 649.

Turtles from Wyoming Oligocene : Lambe, 650 .

Tyrannosaurus, restoration: Osborn, 862.

Wyoming : Gilmore, 408.

\section{Restorations.}

General: Scott, 1033.

Eldonia, Middle Cambrian holothurian : Clark, 204.

Horses, Yale collection: Lull, 709.

Permo-Carboniferous vertebrates, New Mexico: Case et al., 185.

Rancho La Brea quadrupeds : Matthew, 779 .

Tertiary mammals: Scott, 1032.

Tyrannosaurus: Osborn, 862.

Rhode Island.

Paleontology.

Crustacea, coal measures near Pawtucket: Haynes, 475.

Rio Grande region, New Mexico: Hender. son, 478 .

Rivers.

Noatak, Alaska : Smith, 1071.

Californin, Russian River: Holway, 519.

Roal materials.

Petrographic range: Berkey, 68.

Rocks, structural features.

General: Leith, 676.

Breccia : Lawson, 662.

Flow of rocks: Adams, 5.

Magmas, origin from pelitic rocks: Hobbs, 510.

Rocks described. See list p. 164. 
Rutile.

Virginia: Watson and 'Taber', 1247.

Salines.

Nevada, Silver Peak Marsh : Joole, 323. Salt.

General: Turrentine, 1171.

Origin of salt deposits: Grabau, 426.

New York: Newland, 844.

Oklahoma : Snider, 1078.

United States: Phalen, 915.

Virginia, southwestern: Stose, 1127.

Salt deposits, origin: Grabau, 426.

Sand, See also Glass sand; Silica.

New York: Newland, 844.

Pennsylvania, anthracite region: Darton, 282.

United States: Stone, 1119.

Sand dunes, genetic system: Haltenberger, 459.

Saskatchewan.

General: Bryce, 131.

Stratigraphic.

General: Collins and Camsell, 248; Dowling, 326 ; Malcolm, 741.

Saurolophus: Brown, 119.

Sedimentation. See also Erosion.

General: Grabau, 425.

Brown iron ores as cavity fillings: Eckel, 343.

California, Rancho La Brea asphalt bone beds: Stoner, 1120:

Conglomerates, oolites, and sandstones, origin : Brown, 124.

Cross-bedding, White River formation, South Dakota: Winchester, 1313.

Delta deposits, Paleozoic: Grabau, 427.

Marine deposits, classification: Grabau, 431 .

Seismograph, determination of constants : Reid, 961.

Seismology. See also Earthquakes.

General: Gutiérrez Lanza, 452.

Harvard seismographic station, fourth annual report: Woodworth, 1328.

Horizontal pendulum: Denison, 309.

Map for locating earthquakes: Joerg, 558.

Marvin strong-motion seismograph : Davis, 291.

Seismograph, determination of constants: Reid, 961.

Seismographs, vertical motion: Perret, 908.

Undagraph : Klotz, 623.

Selenium.

United States : Hess, 488.

Septaria : Todd, 1162.

Seward Peninsula, Alaska: Smith,.1.070.

Shinarump conglomerate: Gregory, 440.
Shore lines. See also Beaches; Terraces.

Algonquin Beach, deformation: Leverett, 686 .

Contraposed: Clapp, 198.

Ontario, Algonquin beach: Johnston, 561.

Iroquois beach : Coleman, 235.

Ottawa : Keele and Johnston, 582.

Quebec, Covey Hill: Goldthwait, 414.

Montreal: Goldthwait, 413.

Silica : Fenner, 370.

Silurian. For Lover Silurian see Ordovi. cian.

Stratigraphy.

General: Schuchert, 1027.

Correlation of beds: Grabau, 427 .

Ordovician-Silurian boundary: [i]rich, 1187.

Subdivisions: Grabau, 423.

Alaska, Fairbanks quadrangle: Prindle, 929.

Noatak-Kobuk region: Smith, 1068.

Alexandrian series, Illinois and Missouri : Savage, 1007, 1008.

British Columbia, Rocky Mountains : Allan, 13.

Cataract formation: Schuchert, 1025.

Idaho, Lemhi County: Umpleby, 1193.

Illinois, Alexandrian series: Savage, 1007.

Maine, Eastport quadrangle: Bastin and Williams, 56.

Manitoba: Malcolm, $\mathbf{7 4 1 .}$

Stonewall : MacLean, 736 .

Medina : Ulrich, 1188.

Missouri, Alexandrian series: Savage, 1007.

Montana, Philipsburg quadrangle: Emmons and Calkins, 360.

New York, Niagara quadrangle: Kindle and Taylor, 619 .

Niagara Falls and gorge: Taylor, 1149.

Nova Scotia, Arisaig area : Twenhofel, 1172.

Ohio, Findlay borings: Condit, 252.

Ontario: Parks, 886.

Cobalt area : Miller, 817 .

Collingwood: Parks, 890.

Credit River area: Parks, 888.

Hamilton area : Parks, 887.

Manitoulin Island: Williams, 1293.

Niagara Falls and gorge: Taylor, 1149.

Patricia district: Tyrrell, 1175.

southwestern : Williams, 1291.

Pennsylvania, Milesburg Gap, Bellefonte: Brown, 127.

Quebec, Gaspe Peninsula : Clarke, 213.

Richmond formations: Foerste, 379.

Salt deposits, origin: Grabau, 426.

Tennessee, eastern: Burchard, 135.

southeastern: Ulrich and Butts, 1192. 
Silurian-Continued.

stratigraphy-Continued.

Utah, Randolph quadrangle: Richardson, 977.

San Francisco district: Butler, 147 .

Wasatch Mountains: Hintze, 507.

Wyoming, Bighorn dolomite: Blackwelder, 78 .

\section{Paleontology.}

Alexandian series, Illinois and Missouri : Savage, 1008.

Maine, Eastport quadrangle: Williams, 1290.

Washington County, Edmunds and Pembroke formations: Williams, 1289.

Missouri, Alexandrian series: Savage, 1007.

New Brunswick, southern, flora: Matthew, 772 .

Nova Scotia, Arisaig area : Twenhofel, 1172.

Ontario, Patricia district: Parks, 884. Silver.

General, metallic precipitints: Palmer and Bastin, 878 .

Enrichment: Bastin, 53 ; Cooke, 254.

Arizona, Globe district: Tovote, 1168.

Oro Blanco district: Milton, 823 .

British Columbia, Atlin district: Cairnes, 158.

Lynn Creek district: Emmens, 351.

Colorado, Creede district: Emmons and Larsen, 362.

Monarch and Tomichi districts: Crawford, 266.

Mosquito district, Jondon mine: Moore, 834.

Idaho, Custer County: Umpleby, 1195.

Cœur d'Alene district: Hershey, 483 ; Ingalsbe, $\mathbf{5 4 5}$.

Lemhi County: Nichols, 846 ; Umpleby, 1198.

Loon Creek district: Umpleby, 1194.

Mexico, Guerrero, Brabos' district: Flores, 375.

Montana, Elkhorn deposits: Knopf, 628.

Felena region: Knopf, 626,627 .

Phtlipsburg quadrangle: Emmons and Calkins, 360.

Nevada, Antelope district: Schrader, 1021.

Kennedy district: Klopstock, 621 .

Ontario, Cobalt district: Fore, 523; 524 ; Miller, 815, 817.

Gowganda area : Collíns, 244.

South Lorrain : Tyrrell, 1179.

United States: McCaskey, 717.

Utah, San Francisco district: Butler, 147.

Washington, Covada district: Weaver, 1251.
Slate.

Georgia : Maynard, 782.

Tennessee, Pigeon slates: Mayuard, 781.

United States: Coons, 255 ; Dale; 274.

Soapstone.

United States: Diller, 321.

Soil flow: Hobbs, 509.

Solls. .

Filorida : Sellards, 1034.

New Jersey, Sussex aren: Blatr and Jenning, 80.

United States: Marbut et al., 745; Whitney et $a l, 1280$.

Solifluction : Hobbs, 509.

\section{South Carolina.}

Economic.

Phosphate deposits: Waggaman, 1221.

Dynamic and structural.

Earthquake of January 1, 1913 : 'Taber, 1142.

Mineralogy.

Pyroxmangite and skemmatite, Anderson County: Ford and Bradley, $383,384$.

\section{South Dakota.}

Economic.

Homestake ore body : Paige, 870 .

Lithia deposits, Black Hills: Ziegler, 1353.

Dynamic and structural.

Cross-bedding in White River formation : Winchester, 1313.

Physiographic.

Wisconsin drift-plaln, Sloux Falls: Carman, 179.

Stratigraphic.

Black Hills: Paige, 870.

Paleontology.

Interglacial mollusks: Baker, 20.

Spongida.

Cretaceous, New Jersey: Shimer and Powers, 1046.

Springfield quadrangle, Illinois: Shaw and Savage, 1042.

Stegocephalians: Broom, 114.

Stone, See also Building stone.

New York: Newland, 844.

United States: Burchard, 137.

Stratigraphic (general). For regional, see names of States. See also the different systems.

General.

Appalachians, newer and older: Emerson, 350 .

Classification, pre-Cambrian: Miller, 813.

Continental formations in Paleozole: Grabau, 424.

Geologic perlods, delimitation: Sch1chert, 1027. 
Stratigraphic-Continued.

General-Continued.

Laboratory exercises in structural and historical geology: Salisbury and Trowbridge, 1002.

Ordovictan-Silurian boundary: Ulrich, 1187.

Ordovician subdivisions: Grabau, 423.

Ire-Cambrian, Lake Superior region: Lawson, 665 .

Principles of stratigraphy: Grabau, 425.

Red Beds: Henning, 480.

Revision of Paleozoic systems, index to: Ulrich, 1186

Silurian subdivisions: Grabau, 423.

Silurian-Ordovician boundary: Ulrich, 1187.

Correlation.

California, Mohave region: Merriam and Pack; 796.

Carboniferous, Ohio and Kansas: Mark, 747.

Cordillera, forty-ninth parallel: Daly, 278 .

Devonịan: Prosser et al, 937.

Maryland: Swartz, 1133, 1135.

Maryland, Devonian, Upper: Prosser and Swartz, 936.

North America, weștern, and France: Depéret, 311.

Ordovician: Grabau, 427.

Ontario and Quebec: Raymond, 958.

Philipsburg quadrangle: Emmons and Calkins, 360 .

Pre-Cambrían: Cóleman, 240 ; Lawson, 665.

Canada: Wilson, 1304.

Timiskaming region, Ontario: Collins, 247.

Principles: Matthew, 774 ; Ulrich, 1187.

Quaternary, drift deposits, Europe and America : Deeley, 304.

Silurian: Grabau, 427.

Pennsylvania, Bellefonte region: Brown, 127.

'Tertiary, North Pacific coast: Arnold and Hannibal, 18.

Utah, Wasatch Mountains: Hintze, 507.

Tables of formations.

Alaska, Circle quadrangle: Prindle, 930.

Alberta, Rocky Mountains: Allan, 13.

Arizona, San Franciscan field: Robinson, 987.

British Columbia, coast region: Bancroft, 35 .

Cordilleran formations: Daly, 279.

interior plateau region: Drysdale, 331.

Rocky Mountains : Allan, 13.

Tulameen district: Camsell, 170.

Vancoiver Island: Clapp, 199.

Cordillera. forty-ninth parallel: Daly, 278.
Stratigraphic-Continued.

Tables of formations-Continued.

Devonian, Appalachian region: Swartz, 1132.

Florida: Matson and Sanford, 768.

Maryland, Devonian : Swartz, 1132.

Michigan, Arenac County : Gregory, 442.

Montana, Philipsburg quadrangle : Emmons and Calkins, 360 .

New York, Niagara quadrangle: Kindle and Taylor, 619.

Nova Scotia, Arisaig area: Twenhofel, 1172.

Ontario, Gowganda area : Collins, 244. Haliburton-Bancroft area; pre-Cam. brian: Adams and Barlow, 8.

Hamilton area: Parks, 887.

Ordovician: Grabau, 423.

Pre-Cambrian, Lake Superior region: Lawson, 665.

Silurian: Grabau, 423.

Tertiary, North Pacific coast: Arnold and Hannibal, 18.

Virginia, middle western: Watson and Cline, 1243.

Strike, graphical determination of : Cameron, 166.

Study and teaching. See Educational.

Stylolites: Todd, $\mathbf{1 1 6 2 .}$

Subsidence. See Changes of level.

Subterranean water. See Underground water.

Sulphur.

Colorado, Mineral County : Larsen and Hunter, 659.

United States: Phalen, 915.

Utah, San Rafael Canyon: Hess, 487.

Virginia : Springer, 1096.

Wyoming, Sunlight Basin: Hewett, 491.

Surveys

Florida, administrative report: Sellards, 1035 .

Missouri, Report 1911-12; Buehler, 132 .

New Jersey, Report 1912: Kümmel, 642.

North Carolina, Report 1911-12: Pratt, 925.

United States Geological Survey, 34th Annual Report: Smith, 1060

Talc.

New York: Newland, 844.

northern : McDonald, 728.

Ontario, Madoc area : Knight; 625.

United States: Diller, 321.

Tallula quadrangle, Illinois: Shaw and Savage, 1042.

Tantalum.

General : Hess, 488.

Technique.

Analysis of rocks: Connor, 253.

Color plate photographs of rocks: Levison, 683 . 
Technique-Continued.

Determination of minerals of nonmetallic luster : Moses, 836 .

Geologic field methods: Irving, 547; Moon, 833.

Geologic reports : Irving, 548.

Graphical methods in microscopical petrography : Wright, 1339.

Graphical plot for plagioclase feldspars : Wright, 1340.

Index-ellipsold in petrographic-microscopic work: Wright, 1335.

Lens for interference figures: Johannsen, 559.

Oblique illumination in petrographic microscope work: Wright, 1334.

Petrographic description: Berkey, 67.

Petrographic microscope work, index ellipsoid : Wright, 1335.

Plane-table mapping: Higgins, 496.

Refractive indices: Merwin, 805.

Rock sections, preparation of : Flagg, 374.

Rocks, composition: Lincoln and Rietz, 691.

Selsmographs, vertical motion: Perret, 908.

Stereograms in paleobiology: Hudson. 535.

Thermal microscope: Wright, 1333.

\section{Tennessee.}

General.

Etowab, McMinn County : Furdue, 940.

\section{Economic.}

General: Purdue, 943.

Bauxite, Elizabethtown : Watklns, 1238.

Clinton iron ore: MacFarlane, 730.

Coal north of Tennessee Central Railrond: Glenn, 409.

Coal field south of Tennessee Central Railroad: Nelson, 842.

Copper, Ducktown: Gilbert and Pogue, 405.

Ellijay quadrangle: La Forge and Phalen, 643.

Iron deposits: Gordon, 417.

Iron ores, east Tennessee: Burchard, 135.

Mineral products along Tennessee Central Rallroad: Nelson, 843.

Phosphates, Decatur County: Maynard, 783.

Pigeon slates: Maynard, 781.

Dynamic and structural.

Earthquakes in east Tennessee: Gordon, 418 .

Gullied lands, west Tennessee : Purdue, 942.

Stratigraphic.

Ellijay quadrangle: Ia Forge and Fhalen, 643 .

Geologic sectlons in southeastern Tennessee: Ulrich and Butts, 1192.
Tennessee-Continued.

Paleontology.

Eocene flower: Berry, 72.

Mastodon remains: Anon., 1354.

Mineralogy.

General: Purdue, 943.

Meteorite, Carthage : Kaemmerer, 576, 577.

Pisanite, Ducktown : Van Horn, 1209.

Terraces. See also Beaches; Shore lines.

Indiana, Wabash Valley: Dryer, 330.

New York, Mohawk Valley: Spencer, 1088.

Terrestrial gravity and earth movements: Spencer, 1090.

Tertlary.

Stratigraphy.

Alaska, Circle quadrangle: Prindle, 930.

Fairbanks quadrangle: Prindìc, 929.

Koyukuk-Chandalar region: Maddren, 739 .

Noatak-Kobuk region: Smith, 1.068.

Rampart quadrangle: Eakin, 335.

Yentna district : Capps, 177.

Alberta : Malcolm, $\mathbf{7 4 1 .}$

British Columbia, Atlin district : Cairnes, 158.

Coast range: Camsell, 171.

Tulameen district: Camsell, 170.

Vancouver Island: Clapp, 199.

West Kootenay and Boundary districts: LeRoy, 680.

California, Marysville Buttes region: Dickerson, 314.

Mohave region: Merriam and Pack, 796.

Monterey series: Louderback, 703.

Cordillera, forty-ninth parallel: Daly, 278.

Colorado, Creede district : Emmons and Larsen, 362.

De Beque field: Woodruff, 1325.

Rabbit Ears region: Grout et al., 450.

Raton Mesa region: Knowlton, 632.

Florida: Matson and Sanford, 768; Sellards and Gunter, 1038.

Idaho, Custer County: Umpleby, 1195.

Goose Creek district, Cassia County : Bowen, 92.

Horseshoe Bend and Jerusalem Valley: 'Bowen, 91.

Lemhi County : Umpleby, 1193.

southeastern: Schultz and Richards, $\because$ mistit030.

iow̄á,: Rtvèrside sands : Keyes, 611.

Martin̈itue :Guppy, 451.

Mexico, Coáhuila : Haarman, 453.

. northeastern : Whitc, 1275 .

Montana: Stebinger, 1105.

Felena region: Knopf, 626.

Little Sheep Mountain field: Rogers, 995.

southwestern : Pardee, 881. 
Tertiary-Continued.

Stratigraphy-Continued.

Nevada, Antelope district: Schrader, 1021.

New Mexico, Raton Mesa region: Knowlton, 632.

Rio Grande region: Henderson, $47 \mathrm{~s}$.

North Dakota: Leonard, 678.

Williston lignite field: Herald, 481.

Panama, Canal Zone: MacDonald, 723, 726.

Utah, Wasatch Mountains: Loughlin, 706.

Virginia, Coastal Plain: Sanford, 1004.

Washington, south central: Waring, 1233.

southwestern: Weaver, 1252.

Wyoming, Barber coal field, Johnson County: Wegemann, 1259.

\section{Paleontology.}

British Columbia, Kettle River region, plants: Penhallow, 898.

Lebephyllum: Wilson, 1306.

California, Marysville Buttes Eocene fauna : Dickerson, 314.

Mohave Desert, horses: Merriam, 795.

Scutella and Scutaster: Pack, 869. Colorado, Florissant, Coleoptera: Wickham, 1281, 1282.

flowers and fruits : Cockerell, 218. insects: Cockerell, 216, 220, 221. Odonata : Calvert, 165.

Dinosaurs, Colorado: Lee, 671 .

Martinique, Miocene Mollusca: Cossmann, 259.

Panama, Gatun fauna: Brown and Pilsbry, 115.

Miocene Mollusca : Cossmann, 259.

Pliocene, Coastal Plain: Dall, 277.

Tennessee, Eocene flower: Berry, 72.

Wyoming, turtles from oligocene : Lambe, 650 .

Texas.

General.

Southwestern 'Texas: Bosworth, 87.

Volcanic ash: Udden, 1180.

Economic.

Coal, Webb County : Miller, 811 .

Iron deposits: Linton, 701.

\section{Stratigraphic.}

Red beds: Case, 184.

Wichita region: Gordon, 416.

\section{Paleontology.}

Bolosaurus : Broom, 112.ndtrit

Lizard from Permian: Williston, 1299.

Permian reptile: Williston;:1295,

Pliocene Mollusca: Dall, 277. .*

Stegocephala : Broili, 104.

Vertebrate fossils, Panhandle region: Lull, 710 .

Underground water.

Artesian water, southwest Texas: Deussen, 312.

Wichita region: Gordon, 416.

\section{Textbooks.}

Economic geology : Richardson, 976 .

Igneous rocks : Finlay, 371.

Laboratory exercises in structural and historical geology: Salisbury and Trowbridge, 1002.

Mineralogy, determinative: Lewis, 689.

Mineralogy of Colorado: George, 398.

Paleontology : Eastman, 340.

Physical geography : Martin et al., 762.

Structural geology: Leith, 676 .

Thescelosaurus neglectus: Gilmore, 408.

Tin.

Idaho, Lemhi County : Umpleby, 1193.

United States: Hess, 488.

Titaniferous magnetites, microstructure: Singewald, 1054.

Titanium. Sce also Rutile.

United States: Hess, 488.

Virginia: Watson and Taber, 1247.

Titanotheres: Osborn, 864.

Tomichi district, Colorado: Crawford, 266. Topaz.

Mexico: Wittich and Pastor y Ciraud, 1317.

Travertine.

California, Salton Sink: Jones, 572.

Triassic.

Stratigraphy.

Alaska, Noatak-Kobuk region: Smith, 1068.

British Columbia, coast region: Bancroft, 35 .

Skeena River district: McConnell, 719.

Cordillera, forty-ninth parallel: Daly, 278.

Idaho, southeastern: Schultz and Richards, 1030.

Pennsylvania : Wherry, 1266.

Shinarump conglomerate: Gregory, 440.

Sininarump group, Utah: Lawson, 663.

Utah, San Francisco district: Butler, 147.

Virginia, James River basin: Taber, 1141.

Paleontology.

Arizona, fossil forests : Knowlton, 634. Canada, eastern, fossil plants: Holden, 514.

Phytosaur, Palisades: Huene, 538.

Trilobites. See also Crustacea:

Asaphidæ, Canada: Raymond, 955.

Bathyurus: Raymond, 957.

Cambrian, Alberta : Walcott, 1224.

Canadian: Raymond, 954.

Ceraurinus: Barton, 49.

Ceraurus, revision: Raymond and Barton. 959 .

Cryptolithus versus Trinucleus : Raymond, 950.

Devonian. Illinois : Savage. 1009.

Homalonotus ( .-m.) perceensis, I'erce, Quebec: Clarke, 211. 
Trilobites-Continued.

Maryland, Devonian: Clarke and Swartz, 214; Ohern and Maynard, 858; Prosser and Kindle, 935.

Nomenclature: Raymond, 949 .

Ordovician, Maquoketa beds, Iowa : Slocum, 1057.

Trinidad.

Economic.

Coal fields: Catherall, 186.

stratigraphic.

General: Guppy, 451.

Paleontology.

Tertiary: Guppy, 451.

Tungsten.

Colorado, Boulder County: Palmer, 879.

Idaho, Lemhi County: Umpleby, 1193. Nova Scotia: Hills, 506.

United States : Hess, 488.

Tupaida : Gregory, 447.

Turtles. See Reptilia.

Tyrannosaurus, restoration: Osborn, 862." Unconformities:

Carboniferous-Devonian, upper Mississippl valley: Keyes, 604.

Ohio, Bedford-Berea: Burroughs, 140. Onondaga, base : Kindle, 616 .

Paleozolc-pre - Cambrian, on t a rio: Baker, 28.

Rock-boring shells, geologic signiffcance: Barrow, 48.

Underground water (general). Sce also Geysers; M in e r a l waters ; Springs; Thermal waters. For refrional see names of States.

General: McGee, 731.

Ground-water : Kemp, 588.

Mine waters and hot springs: Emmons and Hilrrington, 361.

United States: McGee, 731 .

Upper Silurian. See Silurian.

Uranium. See also Carnotite.

General: Moore and Kithil, 835 .

United States: Hess, 488.

Utah.

Economic.

Asphalt and rare hydrocarbons: Riter, 983.

Carnotite deposits: Curran, 271; Moore and Kithil, 835.

Green River: Hess, 485.

Gold of Shinarump group at Paria : Lawson, 663.

Gypsum, San Rafael Swell: Lupton, 711.

Ozokerite: Higgins, 497.

l'hosphate deposits: Jones, 569.

San Francisco district: Butler, $14 \overline{\mathbf{i}}$, 148.

Sulphates and sulpharsenates as ore minerals : Butler, 149.
Utah-Continued.

Economic-Continued.

Sulphur deposit, San Rafael Canyon: Hess, 487.

Tintic, zinc ores: Zalinski, 1350.

Dynamic-and structural.

Wasatch Mountains: Fintze, 507.

Physiographic.

Wasatch Mountains: Hintze, 507.

Stratigraphic.

La Sal Mountains, Grand County : Hill, 500.

Northern Utah, Randolph quadrangle: Richardson, 977.

San Francisco district: Butler, 147.

Shinarump group: Lawson, 663 .

Wasatch Mountains: Hintze, 507 ; Loughlin, 706.

Paleontology.

Horses, Walker Lake: Merriam, 794. Mineralogy.

Calclovolborthite: Hillebrand and Merwin, 504.

Calcium vanadates: Hillebrand $c t a l$, 505.

San Francisco district: Butler, 147.

Sulphates and sulpharsenates as ore minelals: Butler, 149

Underground water.

Ground water in Box Elder and Tooele counties: Carpenter, 181.

Sulphur Springs, Sat Rafael Canyon: Hess, 487.

Valleys, submerged: Davis, 297.

Vanadium.

General: Moore and Kithll, 835.

Colorado, Placerville: Hess, 486.

New Mexico, Grant County: Larsh, 658.

Sierra de los Caballos: Hess, 484.

United States: Hess, 488.

Vermes. See also Annelida.

Maryland, Devonlan: Clarke and Swartz, 214; Kindle, 614; Ohern, 857.

Vermont.

Economic.

Vershire copper deposits: Thompson, 1157.

Strutiyraphic.

Ordoviclan outlier, Sudbury: Dale, 276.

Taconic Mountains, stratigraphic features: Kelth, 583.

Vertebrata (general). See also Amphibia; Aves; Mammalia ; Pisces; Reptilia.

American Museum expeditions: Matthew, 778 .

Dinosaurs, 'Tertiary : Lee. 671.

Footprints, Kansas Permian: Moodie, 830.

Nomenclature: Matthew, 775 .

Oregon: Shufeldt, 1050.

Recent advances: Moodie, 832. 
Virginia.

Economic.

Apatite deposits: Watson and Taber, 1247.

Brown iron ores as cavity fillings: Eckel, 343.

Gold belt, James River: Taber, 1141.

Mineral production, 1911-1912 : Watson, 1240 .

Mineral resources: Watson, 1241.

Salt and gypsum deposits : Stose, 1127.

Sulphur and iron deposits: Springer, 1096.

Titanium deposits : Watson and Taber, 1247.

Zirconiferous sandstone, Ashlańd : Watson and Hess, 1246.

Dynamic and structural.

Earthquakes, Buckingham County : Taber, 1143 .

Faulting, Piedmont Cambrian: Watson and Cline, 1244.

Physiographic.

Gold belt, James River: Taber, 1141.

Shenandoah Valley, drainage changes : Watson and Cline, 1245.

Stratigraphic.

Central western Virginia: Watson and Cline, 1243.

Gold belt, James River: Taber, 1141.

Petrology.

Central western Virginia: Watson and Cline, 1243.

Dikes, Shenandoah Valley: Watson and Cline, 1243.

Gold belt, James River: Taber, 1141.

Igneous complex, Amherst-Nelson counties:- Watson and Taber, 1249.

New rock types: Watson and Taber, 1248.

Underground water.

Coastal Plain province: Sanford, 1004.

Volcanic ash.

Texas, Kent County : Udden, 11.80.

Volcanic dust, relation to ice ages: Hum. phreys, 540.

Volcanic rocks. See Igneous and volcanic rocks.

\section{Volcanism.}

General: Stevens, 1108.

Ascent of lava : Perret, 910 .

Research at Kilauea, 1911: Perret, 909.

Water and volcanic activity: Day and Shepherd, 300 .

\section{Volcanoes.}

General: Abbot and Fowle, 2.

Climate affected by eruptions?: Abbot, 1 .

Alaska, Katmai Volcano: Martin, 751.

Central America: Sapper, 1006.
Volcanoes-Continued.

Hawaii : Wood, 1320.

Kilauea: Curtis, 272; Day and

Shepherd, 300 .

ejectamenta: Perret, 906.

floating islands: Perret, $90 \mathrm{~B}$

formations in crater : Perret, 907. lava fields: Heim, 477.

lava fountains: Perret, 90\%.

lava lake: Ferret, 004.

subsidence phenomena: Perret, 905 .

Volcanoes, extinct.

Arizona, San Franciscan field: Robinson, 987 .

New Mexico, Raton Mesa region : Mertie, 803.

Panama, Chiriqui : MacDonald, 724.

\section{Washington.}

General.

Bibliography : O’Donnell, 855.

Economic.

Coal, Cowlitz River valley: Collier, 242.

Covada district: Weaver, 15.5.

Dynamic and structural.

Glaciers, Mount Rainier: Matthes, 770.

Mount Rainier, glaciation: Matthes, 771.

Physiographic.

Puget Sound region, glaciation: Bretz, 101.

Stratigraphic.

Cordillera, forty-ninth parallel: Daly, 278.

Cordilleran ice sheet: Stewart, 1115.

Covada district: Weaver, 1251.

Puget Sound region, glaciation : Bretz, 101.

South central Washington: Waring, 1233 .

Tèrtiary :' Weaver, 1252.

marine: Arnold and Hannibal, 18.

Petrology.

Cordillera, forty-ninth parallel: Daly, 278.

Underground water.

South central Washington: Waring, 1233.

Water, constitution: Smyth, $107 \overline{5}$.

Water, underground. See Underground.

Water supply of public lands: Heroy, 482.

Waves: Cornish, 256.

Well records. See Borings.

West Indies. See names of islands.

West Virginia.

Economic.

Cabell, Wayne, and Lincoln counties: Krebs and Teets, 640.

Coal, Pocahontas field : Stow, 1130.

Marion, Monongalia, and Taylor counties: Hennen and Reger, 479 . 
West Virginia-Continued.

Stratigraphic.

Cabell, Wayne, and Lincoln counties: Krebs and Teets, 640.

Marion, Monongalia, and Taylor counties: Hennen and Reger, 479.

I'cleontology.

Conemaugh fauna: Beede, 61.

Fossil flora: White, 1271.

Wind River Mountains, Cenozoic history: Westgate and Branson, 1265.

Wind work.

General: Keyes, 602, 606 .

Antigravitational gradation: Keyes, 603.

Enisled. relief: Keyes, 608 .

Erosional work: Keyes, 600.

\section{Wisconsin.}

General: Dopp, 325.

Geography and industries: Whitbeck, 1268.

Bconomic.

Mineral resources: Holden, 5.12.

Pyrrhotite deposit: Bagg, 22.

Zinc field: Fulsifer, 939.

Stratigraphic.

Pleistocene succession : Weidman, 1260.

Paleontology.

Organic remains in tron-bearing rocks: Cayeux, 1.87.

Postglacial Mollusca, Waukesha County : Baker, 25.

Mineralogy.

Pseudomorphs, limonite after marcasite: North, 851.

Pyrrhotite deposit: Bagg, 22.

Wolframite. See Tungsten.

Wyoming.

Economic.

Barber coal ficld, Tohnson County :

Wegemann, 1.259.

Byron oil field: Rogers, 988 .

Oil fields: Trumbull, 11.70.

Petroleum near Cody: Hewett, 493.

Phosphate deposits: Tones, 569.

Sulphur deposits, Sunlight Basin : Hewett, 491.

Physiographic.

Wind River Mountains, Cenozoic history: Westgate and Branson, 1265.

Stratigraphic.

Barber coal fleld, Johnson County : Wegemann, 1259.

Bighorn dolomite, origin : Blackwelder, 78.

Paleontology.

Angistorhinus, Triassic phytosaur : Meh1, 784.

Amsden fauna: Blackwelder, 76 .
Wyoming-Continued.

paleontolog!l-Continued.

Bathyopsis, Wind River wintuthere: Osborn, 865.

Bird remains: Shufeldt, 1052.

Coralline alga in Ordovician dolonite: Blackwelder, 79.

Dinosaur from Lance formation: Gilmore, 408.

Eomoropus: Osborn, $\cdot 86: 3$.

Gleichenia, Cretaceous : Knowlton, (633.

IIitanotheres: Osborn, 864.

Turtles from Oligocene: Lambe, 650.

Yellowstone National Park: Fenneman, 368 ; Martonne, 763.

Yentna district, Alaska: Capps, 17.

Yosemite Valley, El Capitan morilne: Matthes, 769 .

Yukon.

Economic.

Coal fields: Cairnes, 160.

Gold of Klondike: Tyrrell, 1174.

Klondike, gold lode deposits: MacLean, 737.

physiographic.

Klondike district: Tyrrell, 1174.

Skagway-Whitehorse-Dawson section : Cairnes, 159.

Stratigraphic.

Section, Yukon-Alaska boundury: Cairnes, 161.

Skagway-Whitehor'se-Dawson section: Catrnes, 159.

Paleontology.

Pleistocene camel: Gidaley, 401.

Zeuglodon, Alabama: Gidley, 403.

Zinc.

Arkansas, Boone and Marion counties : Thomas, 1156.

British Columbia, Lynn Creek distr.ct : Emmens, 351.

Colorado, Leadville: Butler, 152.

Monarch and Tomichl districts: Crawford, 266.

Rico district: Ritter, 984 .

Idaho, Cœur d'Alene district: Hershey, 483.

Missouri, Joplin aistrict: Wright, 1333.

southwestern: Heap, 476.

Nevada, Yenow Pine district: Illi, 500.

New Mexico, 'Tres Hermanas district: Wade, 1219.

New York: Nowland, $84 t$.

United States: Siebenthal, 1058.

Utah, Tintic district: Kalinski, 1350.

Wisconsin : Pulsifer, 939.

Zircon.

Virginia, Ashland: Watson and Hess, 1246.

$3 \$ 416^{\circ}-\mathrm{Bull} .5 \$ 4-14-11$ 


\section{LISTS.}

\section{CHEMICAL ANALYSES, 1}

['The numbers refer to entries in the bibliography.]

Abriachanite, 81.

Agririne, $\tau, 659$.

Avgirine-augite, 659 .

Avgirite, 659.

Asgirite, vanadiferous, 659.

AEgirite-augite, vanadiferous, 659.

Albite, 380.

Alkali syenite, 8 .

Alnoite, 7.

Alunite, 1022.

Amphibolite, 8, 199, 1184.

Analcite, $\mathbf{7}, \mathbf{4 7 0}$.

Analcite basalt, 1243 .

Andesine, 8.

Andesite, 266, 570, 987.

Andesite-basalt, 987.

Andose, 8, 273.

Aplite, 244, 360.

A porhyolite, 1234.

Arapahite, 1237.

Argillite, 1303.

Augite, 987.

Augite andesite, 987.

Augite andesite-basalt, 987.

Augite basalt, 987 .

Augite latite, 278.

Augite minette, 278.

Augite porphyrite, 680 .

Augite syenite, 170.

Auvergnose, 8, 1243.

Basalt, 450, 987.

Beaverite, 149.

Biotite, 987.

Biotite dacite, 987.

Biotite-hornblende dacite, 987.

Biotite rhyolite, 987.

Biotite-soda granite porphyry, 987.

Biotite-soda rhyolite, 987.

Bitumen, 1079.

Bloedite, 1012.

Bostonite, 7 .

Breccia, 817.

Calciovolborthite, 488, 504.

Camptonite, 7, 1243.

Carnotite, 488.

Carposiderite, 1316.

Cement materials, 342.

Chalk, 342.

Chert, 158.

Chrysocolla, 381.

Clay, 132, 342, 343, 479, 640, 663, 1303.
Coal, 132, 169, 170, 242, 394, 460, 537, 666, $669,750,930,1068,1201$.

Comendite, 987.

Congressite, 8.

Corundum, 8.

Craigmontite, 8.

Crocidolite, 81.

Crossite, 81.

Cuprodescloizite, 1263.

Custerite, 1197.

Dacite, 987.

Diabase, $244,273,815,817,819,822,987$.

Diallage, 987 .

Diorite, $8,278,750$.

Diorite-andesite, 987.

Diorite-andesite-gabbro-basalt, 987.

Diorite porphyry, 52.

Dolomite, 78, 278, 1078.

Dungannonite, 8 .

Dunite, 278.

Dunose, 170.

Essexite, 7.

Feldspar, 1250.

Felsophyre, 1243.

Gabbro, 8, 244, 278, 822.

Gabbro-basalt, 987.

Gabbro-diorite, 199.

Gastaldite, 81.

Garnet-diopside-epidote rock, 199.

Glaucophane, 81.

Gneiss, 8, 199.

Granite, $8,170,266,278,360,817,1141$, 1234.

Granite felsophyre, 1243.

Granite porphyry, 266, 360, 1234, 1243.

Granite-rhyolite, 987 .

Granite-rhyolite-diorite-andesite, 987.

Granite-rbyolite-syenite-trachyte, 987 .

Granodiorite, 158, 170, 199, 278, 360.

Granophyre, 815, 817, 81.9.

Graphite, 669.

Graphitic anthracite, 669.

Greisen, 627.

Greywacke, 817.

Gypsum, 711.

Halzburgite, 278.

Hessose, 170.

Hetærolite, 384.

Hornblende, 7, 987, 1243.

Hornblende dacite, 987 .

Hornblende-soda andesite-basalt, 087. 
Hornblende-soda dacite, 987.

Hydrozincite, 1316.

Hypersthene dacite, 987.

Hypersthene-hornblende-soda dacite, 987.

Hypersthene-soda dacite, 987.

Igneous rocks, 1076.

Iron ore, $8,132,135,136,322,343,570$, $693,694,1237$.

Jade, 1068 .

Kaolin, 1250.

Kersantite, 278 .

Lassenose, 170.

latite, 987.

Laurvikose, 7 .

Lava, 278, 300, 987.

Lepidomelane, 7 .

Lignite, 481.

Limestone, 132, 199, 266, 278, 342, 479, $551,640,987,1127,1184$.

Magnetite basalt, 1237.

Malignite, 278.

Marble, 134, 987.

Marl, 342 .

Meteorites, 798, 1242.

Miaskose, 1243.

Microperthite, 8.

Micro-granlte, 1234 .

Mine waters, 254, 358, 361, 1087.

Missourite, 278 .

Monchiquite, 7 .

Monchiquose, 1243.

Montrealite, 7 .

Monzonite, 278, 627, 680.

Natrolite, 7.

Nelsonose, 1248.

Nepheline aplite, 7.

Nepheline syenite, 7, 278, 1243.

Nordmarkite, 7 .

Norite, $815,817,819$.

Olivine diabase, 987, 1243.

Oolite, 768

Ourose, 1243.

Palsanite, 987, 1234.

Peridotite, 170.

Peridotite dike rock, 1066.

Petroleum, 1077, 1325.

Phosphate, 126, 783.

Phosphate rock, 880 .

Pledmontose, 1248.

Plumbojarosite, 149 .

Porphyry, 278.

Prehnite, 567.

Pulaskite, 7, 680.

Pulaskite porphyry, 278.
Pyroxene, 987.

Pyroxene andesite, 987.

Pyroxene dacite, 987.

Fyroxene latite, 987.

Fyroxene-hornblende latite, 987.

Pyroxenite, 170.

Pyroxmangite, 383, 384.

Quartz diorite, 266.

Quartz gabbro, 1243.

1 Quartz latite porphyry, 266.

Quartz monzonite, 266, 627, 628.

Quartz monzonite gneiss, 266.

Quartz monzonite porphyry, 266.

Quartzite, 278.

Raglanite, 8.

Rhodusite, 81 .

Rhombenporphyry, 1234 .

Rhyolite, 626, 658, 987.

Riebeckite, 81.

Riebeckite-soda granite porphyry, 987.

Riebeckite-soda rhyolite, 987.

Roselandose, 1248.

Salt brine, 323, 914, 1127.

Sandstone, $\cdot 140,987$.

Schackanite, 278.

Schist, 52.

Shale, 342 .

Silt, 1041.

Skemmatite, 383.

Slate, $342,817$.

Sodalite syenite, 7 .

Stonose, 170.

Sulphur ore, 659 .

Syenite, 8, 278.

Syenite-trachyte, .987 .

Syenite-trachyte-diorite-andesite, 987.

Teschenite, 1243.

Theralite, 7 .

Tinguaite, 7 .

Tonalose, $\mathbf{1 2 4 3 .}$

Toscanose, 1243.

Trachyte, 1243 .

Trachyte-rhyolite, 987 .

Travertine, 363

Triplite, 490.

Tuff, 785 .

Umptekite, 7, 8.

Uraninite, 488 .

Virginose, 1248.

Volcanic ash, 342.

Volcanic gases, 300 .

Water, 132, 361, 363, 785, 1004, 1043.

Zinc ore, 152.

\section{MINERALS DESCRIBED, 1}

Actinolite, 266.

ADgirine-augite, 659 .

Firite, 659.

Agirite, vanadiferous, 659 .

Albite, 380, 990.

Analcite, 470 .

Anglesite, 149.

Annabergite, 817 .
Apatite, 817.
Apophyllite, 1198.
Aragonite, 817.
Argentite, 1208
Argyrite, 1.198 .
Aurichalcite, 1316.
Azurite, 1208.
Barite, 470, 1208. 
Beaverite, 149.

Beudantite, 149.

Bloedite, 1012.

Bornite, 1001.

Brookite, 470.

Calamine, 1198.

Calcivolborthite, 504.

Calcite, 470, 1208.

Carposiderite, 1316.

Cerusite, 922, 1208.

Chalcedony, 369 .

Chalcocite, 1001, 1208.

Chalcopyrite, 231, 1001, 1198.

Chessylite, 1198.

Chlorite, 470.

Chrysocolla, 381 .

Copper, 1208.

Corkite, 149.

Covellite, 1001, 1208.

Cristobalite, 369 .

Cuprite, 1208.

Cuprodescloizite, 1263.

Custerite, 1197.

Datolite, 1198.

Delafossite, 989.

Dyscrasite, 817.

Embolite, 1208.

Enargite, 1001.

Erythrite, 817, 1208.

Galena, 1001, 1208.

Glauberite, 637.

Glaucophane, 81.

Gypsum, 305, 1208, 1318.

Hematite, 1198.

Hetærolite, 384.

Hodgkinsonite, 876 .

Hydrozincite, 1316.

Iodyrite, 638 .

Jarosite, 149 .

Labradorite, 990.

Leverrierite, 996.
Cobaltite, 817.

Ferroprehnite, 567.

Ilmenite, 470, 1054:

Magnetite, 231, 1054.

Malachite, 1208.

Marcasite, 231.

Matildite, 817.

Millerite, 231.

Mimetite, 1198.

Mispickel, 817.

Natramblygonite, 1015.

Nephrite, 1332.

Opal, 920.

Pearceite, 1013, 1208.

Pentlandite, 231.

Perthite, 990

Plagioclase, 990.

Plattnerite, 1040.

Plumbojarosite, 149.)

Polybasite, 1198.

Polydymite, 231.

Prehnite, 567.

Proustite, 1198, 1208.

Pyrargyrite, 817, 1198 .

Pyrite, 231, 470, 1001.

Fyromorphite, 1198.

Pyroxmangite, 383, 384 .

Pyrrhotite, 22, 231.

Quartz, 369, 470.

Roscoelite, 486.

Silver, native, $817,1208$.

Skemmatite, 383.

'Sphalerite, 1001.

Stephanite, 817, 1198.

Strengite, 1017.

Sulphur, 1208.

Tennantite, 1001.

Tetrahedrite, 817, 1001, 1198.

'Topaz, 348, 1198.

Tourmaline, 1016

'Tremolite, 266.

Tridymite, 369.

Triplite, 490.

-Utahite, 149.

Willemite, 875 .

Xanthocanite, 817.

\section{ROCKS DESCRIBED. 1}

Alaskite, 802, 1113.

Alnoite, 7 .

Amphibole granite, 802 .

Amphibolite, 8.

Analcite basalt, 1243.

Andesite, 266, 450, 987, 1195.

Andesite porphyry, 266, 450 .

Andose, 8, 273.

Anorthosite, 6, 8 .

Aplite, 244, 360, 1251.

Aporhyolite, 1234.

Arapahite, 1237.

Arapahose, 1237.

- Augite andesite. 987.

Augite andesite-basalt, 987.

Augite basalt, 987.

Augite porphyrite, 680 .

Augite syenite, 41, 170 .

Auvergnose, 8, 1243.
Basalt, 170, 278, 450, 802, 987.

Biotite dacite, 987.

Biotite granite, 1113.

Biotite granulites, 1101.

Biotite-hornblende dacite, 987.

Biotite monchiquite, 826 .

Biotite-quartz monzonite gneiss, 1247.

Biotite rhyolite, 987.

Biotite-soda granite porphyry, 987 .

Biotite-soda rbyolite, 987 .

Bostonite, 7.

Breccia, 266, 450.

Camptonite, 7, 41, 1243.

Congressite, 8.

Craigmontite, 8 .

Dacite, 626, 802, 987 .

Dacite porphyry, 450.

Diabase, 170, 244, 27:3, :810, flifi. 802,822 , 1141, 1247.

1 The rocks described in Iddings, 544, have not been included in this list. 
J)lopside, 266.

Diorite, 8, $360,1141,1195$.

Diorite-andesite, 987 .

Diolite-andesite-gabbro-basalt, 987.

Dungannonite, 8.

Dunite, 278.

Dunose, 170.

Essexite, 7, 41.

Essexose, 8.

Felsophyre, 1243.

Gabbro, 8, 278, 466, 802, 822, 1101, 1247.

Gabbro-basalt, 987.

Gneiss, 8, 360, 578, 1101.

Granite, $170,244,266,278,360,450,578$, $802,1141,1195,1234$.

Granite felsophyre, 1243.

Granite gneiss, 802 :

Granite porphyry, 170, $266,360,987,1234$.

Granite-rhyolite, 987.

Granlte-rhyolite-diorite-andesite, 987.

Granite-rhyolite-syenite-trachyte, 987.

Granodiorite, 170, 172, 360, 680, 802, 1251.

Greywacke, 244.

Hessose, 170.

Hornblende dacite, 987 .

Hornblende nelsonite, 1247.

Hornblende-soda andesite-basalt, 987.

Hornblende-soda dacite, 987.

Hornblende syenite, 41.

Hypersthene dacite, 987 .

Hypersthene-hornblende-soda dacite, 987.

Hypersthene-soda dacite, 987.

Ilmenite nelsonite, 1247.

Jaspilyte, 1310.

Lamprophyre, 170.

Lassenose, 170 .

Latite, 266, 987, 1.195.

Latite porphyry, 266.

Latite quartz monzonite porphyry, 266 .

Lava, 987.

Laurvikite, 41.

Limestone, 8.

Magnetite basalt, 1237 .

Marble, 266.

Miaskose, 1243.

Monchiquite, 7.

Monchiquose, 1243.

Monmouthite, 8.

Montrealite, 7 .

Monzonite, 627, 680 .

Monzonite gneiss, 1247.

Monzonite porpbyry, 266.

Muscovite granite, 802 .
Nelsonite, 1247.

Nepheline, 8 .

Nepheline aplite, 7 .

Nepheline syenite, 7, 41, 1243.

Olivine diabase, 1243 .

Olivine gabbro, 41.

Ouachitite, 826.

Ourose, 1243.

Pegmatite, 1141.

Peridotite, 170, 1066.

Picrite, 41.

Pitchstone porphyry, 266.

Plumasite, 8.

Porphyrite, 466 .

Porphyry, 1141.

Pulaskite, 7, 680.

Pyroxene dacite, 987 .

Pyroxene-hornblende latite, 987 .

Pyroxene latite, 987 .

Pyroxenite, 170, 466, 1251.

Quartz diabase, 244.

Quartz diorite, 266, 802, 1195.

Quartz gabbro, 1243.

Quartz latite, 450 .

Quartz latite porphyry, 266.

Quartz monzonite, 266, 1195.

Quartz monzonite gneiss, 266.

Quartz syenite, 41.

Quartzite, 8, 266, 1141.

Raglanite, 8 .

Rhyolite, 244, 266, 626; 802, 987, 1141.

Rhyolite porphyry, 266.

Riebeckite-soda granite porphyry, 987 .

Riebeckite-soda rhyolite, $\mathbf{9 8 7}$.

Rutile nelsonite, 1247 .

Schist, 360, 450, 578, 1141.

Shale, 266.

Sillimanite gneiss, 1101.

Slate, 244, 11.41.

Soda dacite, 987 .

Soda rhyolite, 987 .

Stonose, 170.

Syenite, 8, 266, 826, 1247.

Syenite porphyry, 170 .

Syenite trachyte, 987 .

Syenite-trachyte-diorite-andesite, 987.

'I'eschenite, 1243.

'Jinguaite, 7.

Tonalose, 1243.

Toscanose, 1243.

Tourmaline granite, 802 .

Tuff, 1141, 1195.

Umptekite, 8.

\section{GEOLOGIC FORMATIONS DESCRIBED.}

Abitibi group, pre-Cambrian, Canada: Wil. Aftonian beds, Pleistocene: Alden and Steson, 1304.

Acadian, Cambrian, New Brunswick : Young, 1347.

Acadian, Cambrian, Nova Scotia: Hyde, 543.

Adams Lake formation, pre-Cambrlan, British Columbia: Daly, 279 .

Admiralty epoch (glacial), Pleistocene, Washington: Bretz, 101

Admiralty till, Pleistocene, British Colum. bia : Clapp, 199.

\section{binger, 11.}

Aftonian drift, Quaternary : Deeley, 304.

Agassiz serles, Paleozoic, British Columbia : Bowen, 93.

Alachua clay, Pliocene, Florida: Matson and Sanford, 768 .

Albert Canyon division, pre-Cambrian, Brit. ish Columbia: Daly, 279.

Albert series, Carboniferous, New Brunswick: Young, 1347. 
Albertan drift, Pleistocene, Canada: Alden and Stebinger, 11.

Albion moraine, Quaternary, New York: Kindle and Taylor, 619 .

Albion sandstone, Silurian, New York : Kindle and Taylor, 619 .

Albion stage, Silurian: Ulrich, 1187.

Aldridge formation, pre-Cambrian, British Columbia : Schofield, 1020.

Alexandrian series, Silurian, Illinois and Missour : Savage, 1007, 1008.

Algoman, pre-Cambrian, Lake Superior region: Lawson, 665.

Algoman granite, pre-Cambrian, Ontario: Uglow, 1183.

Algonkian, pre-Cambrian, Lake Superior region: Lawson, 665.

Allegany drift, Quaternary: Deeley, 304.

Allegheny formation, Pennsylvanian, Pennsylvania : Campbell et al., 169.

Allegheny series, Carboniferous, West Virginia: Hennen and Reger, 479 ; Krebs and Teets, 640.

Allison Creek formation, Cretaceous, Alberta: Leach, 666 .

Alta shale, Cambrian, Utah: Hintze, 507.

Altyn formation, pre-Devonian, Montana and British Columbia: Daly, 278.

Alum Blufi formation, Oligocene, Florida : Matson and Sanford, 768; Sellards and Gunter, 1038.

Ames limestone, Carboniferous, Ohlo: Condit, 251; Mark, 747.

Ames limestones, Carboniferous, West Virginia : Hennen and Reger, 479.

Ames limestone member; Pennsylvanian, Pennsylvania ; Campbell et al., 169.

Ames or crinoidal limestone, Carboniferous, West Virginia: Krebs and Teets, 640.

Ames shale, Carboniferous, West Virginia : Hennen and Reger, 479.

Amsden formation, Carboniferous, Wyoming: Blackwelder, 76.

Anaktuvuk group, Cretaceous or Jurassic, Alaska: Smith, 1068.

Anarchist series, Washington, British Columbia: Daly, 278.

Anderdon beds, Silurian, Ontario: Parks, 890.

Anderdon limestone, Devonian, Michigan: Nattress, 840.

Andrews schist, Cambrian, Georgia: La Forge and Phalen, 643.

Animikie, pre-Cambrian, Canada: Wilson, 1304.

Animikie, pre-Cambrian, Lake Superior region; Lawson, 665.

Animikie, pre-Cambrian, Ontario: Coleman, 237 ; Parsons, 892.

Ankareh shale, Triassic, Idaho: Schultz and Richards, 1030.

Annabelle shale, Carboniferous, West Virginia: Hennen and Reger, 479.

Apalachicola group, Oligocene; Florida: Matson and Sanford, 768; Sellards and Gunter, 1038.
Appekunny formation, Cambrian, pre-Devonian, Montana and British Columbia : Daly, 278.

Aquia formation, Eocene, Virginia: Sanford, 1004 .

Arago formation, Eocene, Oregon: Arnold and Hannibal, 18.

Archean, pre-Cambrian, Lake Superior re gion: Lawson, 665.

Ardness formation, Mississippian, Nova Scotia : Twenhofel, 1172.

Arisaig series, Silurian, Nova Scotia : Twenhofel, 1172.

Arnoldsburg sandstone, Carboniferous, West Virginia: Hennen and Reger, 479; Krebs and Teets, 640 .

Ashnola gabbro, Carboniferous?, Washington, British Columbia: Daly, 278.

Astoria series, Oligocene, Washington and Oregon: Arnold and Hannibal, 18.

Athabasca sandstone, Cambrian or preCambrian, Saskatchewan: Malcolm, 741.

Attwood series, Carboniferous?, British Columbia: Le Roj, 680 .

Attwood series, Carboniferous?, Washington, British Columbia: Daly, 278.

Aubrey group, Pennsylvanian, Arizona : Robinson, 987.

Aylmer formation, Ordovician, Quebec, Ontario: Raymond, 952.

Badito formation, Colorado: Butters, 153.

Bald Eagle conglomerate, Ordovician, Pennsylvania : Grabau, 427.

Banff limestone, Carboniferous, Alberta : Malcolm, 741; Dowling, 326.

Banff (lower) limestone, Devonian, Alberta : Shimer, 1045.

Banff (lower) limestone, Mississippian, Alberta: Allan, 13.

Banff shales, Carboniferous, Alberta: Malcolm, 741 .

Banff (lower) shale, Mississippian, Alberta: Allan, 13; Shimer, 1045.

Banff (upper) limestone, Pennsylvanian, Alberta: Allan, 13; Shimer, 1045.

Banff (upper) shale, Permian, Alberta : Allan, 13 ; Shimer, 1045.

Bangor limestone, Carboniferous, Tennessee: Burchard, 135.

Barre moraine, Quaternary, New York: Kindle and Taylor, 619.

Bas Obispo folmation, pre-Tertiary, Panama Canal Zone: MacDonald, 723, 726.

Bastion schists, pre-Cambrian, British Columbia: Daly, 279.

Baxter's Brook formation, Ordovician, Nova Scotia: Twenhofel, 1172.

Bayonne batholith, Miocene?, Idaho, British Columbia: Daly, 278.

Bayport formation, Carboniferous, Michigan: Gregory, 442.

Bays sandstone, Ordovician, Tennessee, Virginia, West Virginia, Kentucky : Grabau, 427.

Bearpaw, Cretaceous, Alberta : Dowling, 326. 
Bearpaw formation, Cretaceous, Alberta, Saskatchewan, Manitoba: Malcolm, 741.

Bearpaw shale, Cretaceous, Montana : Stebinger, 1105.

Beauharnois formation, Ordovician, Quebec, Ontario: Raymond, 952.

Beaver group, Carboniferous, West Virginia: Krebs and Teets, 640.

Beaver Mountain group, Cretaceous?: Daly, 278.

Beckwith formation, Cretaceous and Jurassic, Idaho: Schultz and Richards, 1030.

Becraft member, Devonian, Maryland : Swartz et $a l ., 1138$.

Bedford formation, Devonian, Ohio: Prosser, 932 .

Bedford formation, Mississippian, Ohio: Burroughs, 140.

Beech Hill Cove formation, Silurian, Nova Scotia : 'Twenhofel, $\mathbf{1 1 7 2}$.

Beehive formation, Cambrian, Idaho and British Columbia: Daly, 278.

Beekmantown group, Ordovician, Quebec, Ontario: Raymond, 952.

Bellaire sindstone, Carboniferous, Ohlo: Condit, 251.

Belly River, Cretaceous, Alberta : Dowling, 326.

Belly River formation, Cretaceous, Alberta, Saskatchewan : Malcolm, 741.

Belly River series, Cretaceous, Alberta : Dowling, 327.

Belt series, Algonkian, Montana: Emmons and Calkins, 360 ; Knopf, 626.

Belt series, pre-Cambrian, British ${ }^{\bullet}$ Columbia and Alberta: Walcott, 1225.

Beltian system, pre-Cambrian, British Columbia : Daly, 279.

Benson formation, Cretåceous (Upper), British Columbia : Clapp, 199.

Benson limestone, Devonian, Utah : Hintze, 507.

Benton formation, Cretaceous, Alberta : Leach, 666 ; Malcolm, 741.

Benton formation, Cretaceous, Colorado: Grout et al., 450 .

Benton, Cretaceous, Manitoba, Saskatchewan: Dowling, 326.

Benton shale, Cretaceous, North Dakota: Leonard, 678.

Benwood limestone, Carboniferous, West Virginia: Hennen and Reger, 479.

Berea sandstone, Mississippian, Ohio : Burroughs, 140 ; Prosser, 932.

Bergman group, Cretaceous, Alaska : Smith, 1068.

Bertie limestone member, Silurian, New York: Kindle and Taylor, 619.

Bethany limestone, Iowa: Tilton, 1159.

Bighorn dolomite, Ordovician or Silurian, Wyoming: Blackwelder, 78.

Bighorn formation, Cretaceous, Alberta : Malcolm, 741.

Birch Creek schist, pre-Ordovician, Alaska: Maddren, 739; Prindle, 920, 930.
Birmingham shale, Carboniferous, Ohio: Condit, 251; Mark, 747.

Birmingham shale, Carboniferous, IVest Virginia : Krebs and Teets, 640.

Black River formation, Ordovician, Quebec, Ontario: Raymond, 952.

Black River group, Ordovician, Quebec, Ontario: Raymond, 952.

Black River limestones, Ordovician, Ontario: Foerste, 378.

Blacksmith limestone, Cambrian, Utah : Richardson, 975 .

Blackstone shales, Cretaceous, Alberta: Malcolm, 741.

Blaine formation, Permian, Oklahoma : Snider, 1078.

Bloomington formation, Cambrian, Utah : Richardson, 975 .

Bleomsburg red shale, Silurian, Pennsylvania: Grabau, 427.

Bloomsbury formation, Carboniferous, New Brunswick: Young, 1347.

Blueberry Mountain series, New Fampshire: Iahee, 644.

Bohto conglomerate, Oligocene?, Panama Canal Zone: MacDonald, 723, 726.

Bolivar fle clay, Carbontferous, West Vlrginla: Fennen and Reger, 479.

Bon Ami beds, Devonian, Quebec: Clarke, 213.

Bonaventure formation, Devono-Carboniferous, Quebec: Clarke, 21.3.

Bone Valley gravel, Pliocene, Florlda : Matson and Sanford, 768 .

Boss Point formation, Carbontferous, Nova Scotia: Bell, 64.

Boston Bar group, lower Mesozoic, British Columbia: Bowen, 93.

Bosworth formation, Cambrian (Upper:), British Columbia: Allan, 13.

Boulder granite, Turassic, British Columbia : Camsell, 170.

Bowling Green member, Silurian, Illinols and Missouri : Savage, 1007, 1008.

Bow River series, Cambrian, Alberta: Malcolm, 741 .

Braeburn limestone, Carboniferous(?), British Columbia : Calrnes, 158.

Brasstown schist, Cambrian, North Carolina, Georgia : La Forge and l'halen, 643.

Brazean formation, Cretaceous, Alberta : Malcolm, 741 .

Brazer limestone, Mississippian, Utah : Richardson, 975.

Bretonian, Cambrian, Nova Scotia : Hyde, 543.

Bretonian, Cambrian ana Ordovician, New Brunswick : Young, 1347.

Brigham quartzite, Cambrian, Utah : Hintze, 507 ; Richardson, 975.

Bristol llmestone, Carboniferous, West Vlrginia: Hennen and Reger, 479.

Brooklyn formation, Carboniferous?, British Columbia: I.eRoy, 680 . 
Brooklyn formation, Carboniferous and post-Carboniferous, British Columbia: IseRoy, 680 .

Broughton series, pre-Cambrian?, Quebec: Harvie, 466.

Brown's Mountain group, Ordovician, Nova Scotia: Twenhofel, 1172.

Brunswick shale, Trias, Pennsylvania: Wherry, 1266.

Brush Creek horizon, Carboniferous, Ohio: Condit, 251.

Brush Creek limestone, Carboniferous, Ohio: Mark, $\mathbf{7 4 7}$.

Brush Creek limestone, Carboniferous, West Virginia: Krebs and Teets, 640.

Brush Creek limestore and shale, Carboniferous, West Virginla: Hennen and Reger, 479 .

Buffalo sandstone, Carboniferous, Ohio: Condit, 251.

Buffalo sandstone, Carboniferous, West Virginia : Hennen and Reger, 479.

Buffalo sandstone, Carboniferous, West Virginia : Krebs and Teets, 640.

Buffalo sandstone member, Pennsylvanian, Pennsylvania : Campuell et al., 169.

Buffalo Hart moraine, Quaternary, Illinois : Slaw and Savage, 1042.

Burgess shale, Cambrian (Middle), AIberta, British Columbia: Allan, 13.

Burgoon sandstone member, Mississippian, Pennsylvania : Campbell et al., 169.

Burton sandstone, Carboniferous, West Virginia: Hennen and Reger, 479.

Cabots Head beds, Silurian, Ontario: Grabau, 427.

Câche Creek formation, Carboniferous, British Columbia: Drysdale, 331.

Cache Creek group, Paleozolc, British Columbia : Bowen, 93.

Caimito formation, Oligocene, Panama Canal Zone: MacDonald, $723,726$.

Caloosahatchee marl, Pliocene, Florida: Matson and Sanford, 768 .

Calvert formation, Miocene, Virginia : Sanford, 1004.

Cambridge limestone, Carboniferous, Ohio: Condit, 251 ; Mark, 747.

Campbells Creek limestone, Carboniferous, West Virginia : Krebs and T.eets, 640.

Canajoharie shale, Ordovician: Grabau, 427.

Canyon formation, Carboniferous, Texas: Gordon, 416.

Carbondale formation, Pennsylvanian, Illinois: Shaw and Savage, 1042.

Caribbean limestone, Pliocene, Panama Canal Zone: MacDonald, 723, 726.

Carlton moraine, Quaternary, New York: Kindle and Taylor, 619.

Carmack basalts, Tertiary or Pleistocene, British Columbia : Cairnes, 158.

Cascade gneissic batholith, Jurassic, Washington, British Columbia: Daly, 278.

Cassville plant shale, Carboniferous, West Virginia: Hennen and Reger, 479.
Castle Mountain group, Cambrian and Ordovician, Alberta: Malcolm, 741.

Castle Peak stock, Miocene, Washington, British Columbia: Daly, 278.

Cataract formation, Ordovician, Ontario: Parks, 887, 888, 890.

Cataract formation, Silurian, New York and Ontario: Schuchert, 1023, 1025.

Cataract formation, Silurian, Ontario: Williams, 1291, 1293.

Catarict (Medina) formation, New York and Ontario: Taylor, 1149.

Cataract sandstone, Silurian, Ontario: Parks, 888.

Cat Head limestone, Ordovician, Manitoba : Dowling, 326 ; Malcolm, 741; Wallace, 1230.

Cathedral batholith, Tertiary, Washington, British Columbia: Daly, 278.

Cathedral formation, Cambrian (Middle), Alberta, British Columbia: Allan, 13.

Catoctin schist, pre-Cambrian, Virginia : Watson and Cline, 1244.

Catskill formation, Devonian, Maryland : Prosser and Swartz, 936; Swartz, 1137.

Catskill formation, Devonian, New York to Virginia : Barrell, 45.

Cattaraugus formation, New York, Pennsylvania: Barrell, 45 .

Cayuga group, Silurian, New York: Kindle and Taylor, 619.

Cedar district formation, Cretaceous (Upper), British Columbia: Clapp, 199.

Cedar limestone, Devonian, Missouri, Iowa: Keyes, 604 .

Cedar volcanic series, Oligocene, British Columbia: Camsell, 170.

Cedar Valley formation, Devonian, Iowa : Keyes, 610.

Chagrin formation, Devonian, Ohio: Prosser, 932.

Chalky Mount group, Barbados: Cunningham-Craig, 270.

Chancellor formation, Cambrian (Upper), British Columbia: Allan, 13.

Channahon limestone, Silurian, Illinois : Savage, 1007, 1008.

Chase quartzite member, pre-Cambrian, British Columbia: Daly, 279.

Chattahoochee formation, oligocene, Florida: Matson and Sanford, 768; Sellards and Gunter, 1.038.

Chattanooga shale, Devonian, Tennessee: Burchard, 1.35 .

Chattanooga shale, Mississippian, Tennessee: Butts, 155.

Chazy, Ordovician, Quebec, Ontario: Raymond, 952 .

Chehalis formation, Eocene, Washington: Arnold and Hannibal, 1.8.

Chelmsford sandstone, pre-Cambrian, Ontario: Coleman. 231, 237.

Chemung formation, Devonian, New York, Pennsylvania: Barrell, 45.

Chemung sandstone member, Devonian, Maryland: Swartz, 1137. 
Chesapeake group, Miocene, Virginia: Sanford, 1004.

Chetang limestones, Cambrian, British Columbia and Alberta: Walcott, 1225.

Chickamauga limestone, Ordovician, Tennessee : Burchird, 135.

Chieftain Hill volcanics, Tertiary (?), British Columbia : Calrnes, 158.

Chilliwack series, Carboniferous, Washington, British Columbia: Daly, 278.

Chilliwack volcanic folmation, Carboniferous, Washington, British Columbia.: Daly, 278.

Chipola marl member, Oligocene, Florida: Matson and Sanford, 768.

Choctawhatchee marl, Miocene, Florida: Matson and Sanford, 768; Sellards and Gunter, 1038.

Chopaka basic intrusives, Carboniferous?, Washington: Daly, 278.

Choptank formation, Miocene, Virginia: Sanford, 1004.

Chouteau limestone, Carboniferous, Missouri : Keyes, 604.

Chugwater formation, Triassic, Wyoming: Blackwelder, 76.

Cisco formation, Carboniferous, Texas: Gordon, 416.

Claggett, Cretaceous, Alberta: Dowling, 326.

Claggett formation, Cretaceous, Alberta : Malcolm, 741.

Claggett shale, Cretaceous, Montana : Stebinger, 1105.

Clarksburg limestone, Carboniferous, West Virginia: Hennen and Reger, 479 ; Krebs and 'leets, 640 .

Clarksburg red shale, Carboniferous, West Virginia: Hennen and Reger, 479.

Clear Fork formation, Permian, 'Texas : Gordon, 416.

Cleawater shale, Cretaceous, Alberta : Malcolm, 741.

Cleveland shale, Devonian, Ohio; Prosser, 932.

Cleveland shale, Mississippian, Ohio: Burroughs, 140.

Clinch sandstone, Ordovician-Silurian, Virginia, West Virginia, Kentucky: Grabau, 427.

Clinton formation, Silurian, New York: Kindle and Taylor, 619 .

Clinton formation, Silurian, Ontario: Parks, 887, 888.

Clinton limestone, Silurian, New York and Ontario: Taylor, 1149.

Clinton lower limestones, Silurian, New York and Ontario: Schuchert, 1023.

Clinton shale, Silurian, New York and Ontario: Schucbert, 1023.

Clinton upper limestone, Silurian, New York and Ontario: Schuchert, 1023.

Coalburg sandstone, Carboniferous, West Virginia: Krebs and Teets, 640 .

Coast Range intrusives, Jurassic(?), British Columbia: Cairnes, 158.
Coast Range intrusives, upper Jurassic(?), British Columbia: Bancroft, 35.

Cobalt series, pre-Cambrian, Canada: Wilson, 1304.

Cobalt series, pre-Cambrian, Ontario: Burrows, 144; Collins, 244, 247; Miller, $815,817,820$.

Cobalt series, pre-Cambrian, Ontario and Quebec: Wilson, 1303.

Cobleskill dolomite, Silurian, New York: Kindle and Taylor, 619 .

Coconino sandstone, Pennsylvanian, Arlzona: Robinson, 987.

Coeymans member, Devonian, Maryland : Swartz et al., 1138.

Coldbrooktan Cambian, Nova Scotia, New Brunswick: Hyde, 543.

Coldbrookian, pre-Cambrian, New Brunswick: Young, 1347.

Coldwater group, Eocene?, British Columbia: Drysdale, 331.

Coldwater series, Oligocene, British CoJumbia : Camsell, 170.

Collingwood black shales, Ordovician, Ontario: Foerste, 378.

Collingwood formation, Ordovician, Ontario: Foerste, 378 ; Parks, 890.

Collingwood formation, Ordovician, Quebec, Ontario: Raymond, 952.

Colorado formation, Cretaceous, Montana: Emmons and Calkins, 360.

Colorado shale, Cretaceous, Montana: Stebinger, 1105.

Colquitz gneiss, Mesozoic, British Columbia : Clapp, 199.

Columbia group, Pleistocene, Virginla: Sanford, 1004.

Columbus limestone, Devonian, Ohio: Kindle, 616.

Colwood sands and gravels, Pleistocene, British Columbia: Clapp, 199.

Comanche serles, Cretaceous, Iexas: Gordon, 416.

Conemaugh formation, Carboniferous, Ohio : Condit, 251.

Conemaugh formation, Pennsylvanian, Pennsylvanta: Campbell et al., 169.

Conemaugh series, Carboniferous, West Virginia: Hennen and Reger, 479; Krebs and Teets, 640.

Connellsville sandstone, Carboniferous, Ohio: Condit, 251.

Connellsville sandstone, Carboniferous, West Virginia: Hennen and Reger, 479; Krebs and 'Teets, 640.

Connellsville (lower) sandstone, Carboniferous, West Virginia: Hennen and Reger, 479.

Connoquenessing sandstone, Pennsylvanian, Pennsylvania: Campbell et al., 169.

Connoquenessing (lower), Carboniferous, West Virginia: Hennen and Reger, 479.

Connoquenessing (upper) sandstone, Calboniferous, West Virginia: Hennen and Reger, 479. 
Copper Cliff arkose, pre-Cambrian, Ontarío: Coleman, 237.

Coralville formation, Devonian, Iowa : Keyes, 610.

Cordilleran glaciation, Pleistocene, Rocky

Mountains: Alden and Stebinger, 11.

Cordova sands and gravels, Pleistocene, British Columbia: Clapp, 199.

Corral Creek formation, pre-Cambrian, Alberta: Allan, 13.

Cortlandt series, pre-Cambrian, New York: Kemp, 588.

Coryell syenite batholith, . Washington, British Columbia: Daly, 278.

Cougar formation, pre-Cambrian, British Columbia : Daly, 279.

Coutchiching, pre-Cambrian, Lake Superior region: Làwson, 665.

Coutchiching, pre-Cambrian, Ontario: Uglow, 1183.

Coutchiching series, . pre-Cambrian, Canada: Wilson, 1304.

Covada formation, Carboniferous?, Washington: Weaver, 1251.

Cowrun sandstone, Carboniferous, Ohio: Condit, 251.

Cranberry formation, Cretaceous (Upper), British Columbia: Clapp, 199.

Creston formation, Cambrian and preCambrian, Idaho, Montana, and British Columbia: Daly, 278.

Creston formation, pre-Cambrian, British Columbia: Schofield, 1020.

Creston red. shale, Carboniferous, West Virginia: Hennen and Reger, 479.

Crill limestone, Cretaceous, Iowa : Keyes, 609.

Croasdale quartzite, Șilurian, New Jerses: Grabau, 427.

Crowsnest volcanics, Cretaceous, Alberta : Leach, 666 .

Cucuracha formation, Oligocene, Panama Canal Zone: MacDonald, 723, 726.

Culebra formation, Oligocene?, Panama Canal Zone: MacDonald, 723.

Culebra formation, Tertiary (Eocene or Oligocene), Pinama Canal Zone: MacDonald, 726.

Cultus formation, Triassic, Washington, British Columbia: Daly, 278.

Custer granite-gneiss, Jurassic?, Washington, British Columbia: Daly, 278.

Cutler formation, Permian, Colorado: Butters, 153 .

Cyrene member, Sllurian, Illinois and Missourf: Savage, 1007, 1008.

Dakota, Cretaceous, Manitoba, Saskatchewan : Dowling, 326.

Dakota formation, Cretaceous, Alberta : Leach, 666; Malcolm, 741.

Dakota? formation, Cretaceous, Colorado: Grout et al., 450 .

Dakota sandstone, Cretaceous, New Mexico: Lee, 671 .

Dakota sandstone, Cretaceous, North Dakota : Leonard, 678 .
Dawson arkose, Tertiary (Eocene), Colo. rado : Lee, 671

Day Creek dolomite, Permian, Oklahoma: Snider, 1078.

Decewsville formation, Devonian, Ontario: Kindle, 616.

De Courcy formation, Cretaceous (Upper), British Columbia : Clapp, 199.

Delicias beds, Paleozoic, Mexico : Haarman, 453.

Dennys formation, Silurian, Maine: Bastin and Williams, 56 ; Williams, 1289.

Denver formation, Eocene, Colorado: Knowlton, 632 .

Denver formation, Tertiary (Eocene), Colorado: Knowlton, 632 .

Departure Bay calcarenites, Cretaceous (Upper), British Columbia: Clapp, 199.

Jes Moines formation, Pleistocene, Iowa: Tilton," 1159

Dewdney formation, Cambrian, Idaho and British Columbia: Daly, 278.

Dog Creek shale member, Permian, Oklahoma : Snider, 1078.

Dolores formation, Triassic, Colorado: Butters, 153

Don beds, Pleistocene, Ontario: Coleman, $234,236$.

Double Mountain formation, Permian, Texas : Gordon, 416.

Dry Creek shale, Cambrian, Montana : Knopf, 626.

Dunkard series, Carboniferous, West Virginia: Hennen and Reger, 479; Krebs and Teets, 640 .

Dunnellon formation, Pliocene, Florida : Sellards, 1036.

Dunvegan beds, Cretaceous, Alberta: Malcolm, 741 .

Dunvegan sandstones, Cretaceous, British Columbia: Galloway, 394.

Eagle formation, Cretaceous, Alberta: Malcolm, 741 .

Eagle granodiorite, Jurassic, British Columbia: Camsell, 170.

Eagle sandstone, Cretaceous, Montana : Stebinger, 1105.

East Lynn sandstone, Carboniferous, West Virginia: Krebs and Teets, 640 .

Eastport formation, Silurian, Maine: Bastin and Williams, 56; Williams, 1289.

Eastwellington formation, Cretaceous (Upper), British Columbia: Clapp, 199.

Eden clays, Ordovician, Ontario: Foerste, 378.

Eden formation, Ordovician, Ontario : Parks, 890.

Eden limestone, Ordovician, Ontarlo: Foerste, 378 .

Edgewood limestone, Silurian, Illinois and Missouri : Savage; 1007, 1008.

Edmonton, Cretaceous, Saskatchewan, AIberta : Dowling, 326.

Edmonton formation, Cretaceous, Alberta: Dowling, 327 ; MacLean, 736; Malcolm, 741. 
Edmunds formation, Silurian, Maine: Bastin and Williams, 56; Williams, 1289.

Eldon formation, Cambrian (Middle), Alberta, British Columbia: Allan, 13.

Elephant limestone, Carboniferous (Pennsylvanian?), Utah: Butler, 147.

Elk conglomerates, Cretaceous, Alberta: Lench, 666.

Ilk Lick limestone, Carboniferous, West Virginia : Hennen and Reger, 479; Krebs and Teets, 640 .

Rlk River formation, Fliocene, Oregon : Arnold and Hannibal, 18.

Illensburg formation, Miocene, Washington: Waring, 1282.

Ellis formation, Jurassic, Montana: Emmons and Calkins, 360 ; Pardee, 880.

Nim Grove limestone, Carboniferous, West Virginia: Hennen and Reger, 479.

Nmbar formation, Permian?, Wyoming: Blackwolder, 76 .

Emperador limestone, Oligocene, Panama Canal Zone: MacDonald, $723,726$.

Empire formation, Miocene, Oregon: Arnold and Hannibal, 18.

Empire shale, Algonkian, Montana : Knopf, 626.

Inid formation, Permian, Oklahoma: Snlder, 1078.

Fparchean interval, pre-Cambrian, Lake Superlor region: Lawson, 665 .

Essex limestone, Silurian, Illinois and Missouri : Savage, 1007, 1008.

Etchemintan, Cambrian, New Brunswick : Young, 1347.

Etcheminian, Cambrian, Nova Scotia : Hyde, 543

Etna quartz monzonite porphyry: Crawford, 266 .

Nwing limestone, Carboniferous, Ohlo: Condit, 251; Mark, 747.

Ewing llmestone, Carboniferous, West VIrginfa: Hennen and Reger, 479.

Extension formation, Cretaceous (Upper) British Columbia: Clapp, 199.

Fabre series, pre-Cambrian, Ontario: Collins, 247.

Fairview formation, Cambrian (Lower), Alberta, British Columbla: Allan, 13.

Fayette formation, Devonian, Iowa: Keyes, 610.

Fernando formation, Tertiary, California : Iouderback, 703 .

Fernle formation, Jurassic, Alberta : Leach, 666.

Fernie shale, Jurassic, Alberta: Allan, 13; Malcolm, 741

Fernie shale, Jurassic, British Columbia, Alberta, Saskatchewan : Dowling, 326.

Fish Creek sandstone, Carboniferous, West Virginia: Hennen and Reger, 479.

Fish Haven dolomite, Ordovician, Utab : Richardson, 975.

Fitch Hill arkose, New Fampshire: Lahee, 644.
Fitch Fill granite gneiss, New Fampshire: Lahee, 644.

Flathead beds, Cretaceous, Alberta: Leach 666.

Flathead quartzite, Cambrian, Montana : Billingsley, 75; Emmons and Calkins, 360 ; Knopf, 626.

Fordham gneiss, pre-Cambrian, New York : Kemp, 588.

Fort Iayne formation, Carboniferous, Tennessee: Burchard, 135.

Fort St. John shales, Cretaceous, Alberta: Malcolm, 741

Fort St. John shales, Cretaceous, British Columbia: Galloway, 394.

Fort Union formation, Tertlary, Montana : Rogers, 995 ; Stebinger, 1105.

Fort Union formation, Tertiary (Focene), North Dakota: Herald, 481.

Fort Union formation, Tertlary, North Dakota : Leonard, 678.

Fort Union formation, Tertlary, Wyoming : Wegemann, 1259.

Fountain formation, Pennsylvanian, Colorado: Butters, 153.

Fox Fills sandstone, Cretaceous, North $\mathrm{Da}$ kota : Leonard, 678.

Freeport (lower) limestone, Carboniferous, West Virginia: Hennen and Reger. 479; Krebs and 'Teets, 640.

Freeport (lower) sandstone, Carboniferous, West Virginia: Hennen and Reger, 479.

Freeport (upper) limestone, Carboniferous, West Virginia: Hennen and Reger, 479.

Freeport (upper) sandstone, Carbonlferous, West Virginia; Hennen and Reger, 479. Krebs and Teets, 640.

Fulton green shale, Carboniferous, West Virginfa: Hennen and Reger, 4'i9.

Fulton shale, Ordovician, Cincinnati region: Grabau, 427.

Gabriola formation, Cretaceous (Upper), British Columbla: Clapp, 199.

Galisteo sandstone, Tertiary?, New Mexico : Lee, 671.

Galton series, Montana and British Columbia: Daly, 278.

Garden City limestone, Ordoviclan, Utah : Richardson, 975.

Garfield formation, Pennsylvanian, Colorado: Crawford, 266.

Gaspe sandstone, Devonian, Quebec : Clarke, 213.

Gasport limestone member, Sllurian, New York: Kindle and Taylor, 619.

Gateway formation, Cambrian?, British Columbia: Schofleld, 1020,

Gateway formation, Montana and British Columbia: Daly, 278.

Gatun formation, Oligocene, Panama Canal Zone: MacDonald, 723, 726.

Genesee black shale, Devonlan, Maryland: Swartz, 1137.

Geneva limestone, Devonian, Indiana: Kindle, 616. 
George River series, pre-Cambrian, Nova Scotia: Young, 1347.

Gilit conglomerate, Quaternary, Arizon:1: Meinzer, 785.

Gilboy -sitndstone, Carboniferous, West Virginia: Hennen and Reger, 479; Krebs and Tects, 640 .

Gilmore limestone, Carboniferous, West Virginia: Hennen and Reger, 479.

Gilmore sandstone, Carboniferous, West Virginia: Hennen and Reger, 479.

Girardeau limestone, Silurian, Illinois and Missouri : Savage, 1007, 1008.

Glacier division, pre-Cambrian, British Columbia: Daly, 279.

Gold-bearing series, pre-Cambrian, Nova Scotia : Faribault, 367.

Goldenville formation, Cambrian, or pre Cambrian, Nova Scotia : Malcolm, 740.

Goldenville formation, pre-Cambrian, Nova Scotia: Faribault, 367 .

Goodsir shales, Ordovician, British Columbia : Allan, 13.

Grafton sandstone, Carboniferous, West Virginia : Hennen and Reger, 479; Krebs and Teets, 640.

Grainger shale, Devonian and Carboniferous, 'Tennessee: Burchard, 135.

Grampian limestone, Cambrian? and Ordovician, Utah : Butler, 147.

Grand Forks schist, Washington, British Columbia: Daly, 278.

Grand Greve beds, Devonian, Quebec: Clarke, 213.

Grand Rapids sandstone, Cretaceous, Alberta: Malcolm, 741.

Grand Rapids (lower) formation, Carboniferous, Michigan: Gregory, 442.

Grand Rapids (upper) formation, Carboniferous, Michigan: Gregory, 442.

Grassy black shales, Carboniferous, Missouri, Iowa : Keyes, 604.

Great Smoky formation, Cambrian, North Carolina, Georgia: La Forge and Phalen, 643.

Greenbrier limestone, Mississippian, West Virginia : Hennen and Reger, 479.

Green Pond conglomerate, Silurian, New York, New Jersey : Grabau, 427.

Green River formation, Tertiary, Colorado : Woodruff, 1.325 .

Greer formation, Permian, Oklahoma : Snider, 1078.

Grenville series, pre-Cambrian, Canada : Wilson, 1305 .

Grenville series, pre-Cambrian, New York: Kemp, 588 ; Miller 822.

Grenville series, pre-Cambrian, Ontario: Adams and Barlow, 8; Coleman, 231, 237.

Grenville series, pre-Cambrian, Quebec: Stansfield, 1101.

Greyson(?) shale, Algonkian, Montana : Himmons and Calkins, 360.
Grinnell formation, Cambrian, pre-Dev" nian, Montina and British Columbla : Daly, 278.

Guelph formation, Silurian, Ontario : Parks, 887.

Halifax formation, Cambrian, Nova Scotia : Malcolm, 740 .

Halifax formation, pre-Cambrian, Nova Scotia : Faribault, 367.

Hamilton member, Devonian, Maryland : Prosser et al., 937.

Hamilton shales, Devonian, Ontario : Parks, 886, 887, 890 .

Hammond fire clay, Carboniferous, West Virginia: Hennen and Reger, 479.

Hannibal shales, Carboniferous, Missouri, Iowa : Keyes, 604.

Fardman fire clay, Carboniferous, West Virginia: Hennen and Reger, 479.

Farrington formation, Triassic, Utah : Butler, 147.

Haslam formation, Cretaceous (Upper), British Columbia: Clapp, 199.

Hasmark formation, Cambrian, Montana : Billingsley, 75; Emmons and Calkins, 360.

Hastings series, pre-Cambrian, Ontario: Adams and Barlow, 8 .

Hawarden shales, Cretaceous, Iowa : Keyes, 609.

Hawthorne formation, Oligocene, Florida : Matson and Sanford, 768.

Hawthorne formation, Oligocene, Florida: Sellards and Gunter, 1038.

Hazleton group, Cretaceous, British Columbia : McConnell, 719 .

Hector formation, pre-Cambrian, Alberta : Allan, 13.

Hefty formation, Montana and British Columbia : Daly, 278.

Helderberg formation, Devonian, Mary. land: Swartz et al., 1138.

Helena limestone, Algonkian, Montana : Knopf., 626.

High Falls shale, Silurian, New York: Grabau, 427.

Hitka formation, Cambrian, British Colum. bia and Alberta : Walcott, 1225.

Hodges shale member, Cambrian, Utah : Richardson, 975.

Homewood sandstone, Carboniferous, West Virginia: Hennen and Reger, 479; Krebs and Teets, 640 .

Homewood sandstone, Pennsylvanian, Pennsylvania : Campbell et al., 169.

Horsethief sandstone, Cretaceous, Montana : Stebinger, 1105.

Horton series, Carboniferous, Nova Scotia : Bell, 64.

Hota formation, Cambrian, British Columbia and Alberta: Walcott, 1225.

Fozomeen series, Carboniferous, Washington, British Columbia: Daly, 278.

Hudson series, Ordovician, New York, Pennsylvania: Grabau, 427. 
Hundred sandstone, Carboniferous, West Virginia: Hennen and Reger, 479.

Huntingdon formation, Eocene, Washington, British Columbia: Daly, 278.

Huron shale, Devonlan, Obio: Prosser, 932. Huronian, pre-Cambrian, Canada: Wilson, 1305.

Huronian, pre-Cambrian, Ontario: Collins, $244,247$.

Huronlan system, pre-Cambrian, Canadia : Wilson, $130^{4}$.

Huronian (lower), pre-Cambrian, Lake Superior region: Lawson, 665.

Huronian (lower), pre-Cambrian, Ontario: Coleman, 231, 237 ; Parsons, 892.

Huronian (upper), pre-Cambrian, Lake Superior region: Lawson, 665.

Huronian (upper) (Animikie), pre-Cambrian, Ontario: Passons, 892.

Huronian (upper) or Animikie, pre-Cam. brian, Ontario: Coleman, 231, 237.

Ice River intrusive complex, post-Cretaceous, Alberta: Allan, 13.

Illecillewaet quartzite, pre-Cambrian, British Columbia: Daly, 279.

Illinolan drift, Quaternary: Deeley, 304.

Illinoian drift, Quaternary, Illinois : Shaw and Savage, 1041.

Ingleside formation, Pennsylvanian, Colorado: Butters, 153.

Intermediate limestone, Devonian, Alberta: Allan, 13.

Intermedlate serles, Devonian, Alberta: Malcolm, 741 .

Inwood marble, pre-Cambrian, New York: Kemp, 588.

Ione formation, Miocene, Callfornia : Dickerson, 314.

Irene conglomerate formation, pre-Cambrian, Idaho and British Columbia : Daly, 278.

Irene volcanic formation, pre-Cambrian, Idaho and British Columbla: Daly, 278.

Irondequoit limestone member, Silurian, New York: Kindle and Taylor, 619.

Jackass Mountain series, Cretaceous, British Columbia: Bowen, 93.

Jacksonville formation, Miocene, Florida : Matson and Sanford, 768; Sellards and Gunter, 1038.

James River formation, Ordovician, Nova Scotia: Twenhofel, 1172.

Jefferson dolomite, Devonian, Utah: Richardson, 975 .

Jefferson limestone, Devonian, Montana Fmmons aud Calkins, 360 ; Knopf, 626.

Jefferson limestone, Devonian, Montana and British Columbia: Daly, 278.

Jefferson limestone, Devonian, Utah: Hintze, 507.

Jeffersonville limestone, Devonian, Kientucky : Findle, 616.

Jennings formation, Devonian, Maryland : Barrell, 45: Prosser and Swart\%, 936; Swartz, 1137

Jerseyenn drift, Quaternary: Deeley, 304.
Joggins formation, Carboniferous, Nova Scotia: Bell, 64.

Johannian, Cambrian, New Brunswick : Young, 1347.

Johannian, Cambrian, Nova Scotia : Hyde, 543.

Johnstown cement limestone, Carboniferous, West Virginia: Hennen and Reger, 479.

Jollytown Fmestone, Carboniferous, West Virginia: Hennen and Reger, 479.

Tollytown sandstone, Carboniferous, West Virginia: Hennen and Reger, 479.

Judith River formation, Cretaceous, Montana: Stebinger, 1105.

Juniata formation, Penusylvania : Grabau, 427.

Kagawong member, Silurian, Ontarto: Williams, 1291.

Kalibab limestone, Pennsylvanian, Arl\%ona: Robinson, 987.

Kamloops volcanic group, Miocene?, Isritish Columbia: Drysdale, 331.

Kamouraska formation, Cumbrian ?, Quebec: Young, 1347.

Kinnawha series, Carboniferous, West Virginia: Krebs and Ieets. 640.

Kangaroo formation, Permo-Pennsylvanian (?), Colorado: Crawford, 266.

Kansan drift, Quaternary: Deeley, 304.

Kansan (?) drift, Quaternary, Illinois : Shaw and Savage, 1042.

Kansan series, Pleistocene: Alden and Stebinger, 11.

Keefer sandstone, Silurian, Maryland, West Virginia: Grabau, 427.

Keewatin, pre-Cambrian, Canada: Wilson, 1304.

Keewatin, pre-Cambrian, Ontario : Burrows, 144 ; Coleman, 231, 237 ; Collins, 244; Miller, 815 ; Parsons, 892 ; Uglow, 118:3.

Keewatin, pre-Cambrian, Quebec: Bancroft, 36 .

Keewatin complex, pre-Cambrian, Ontario: Miller, 817.

Keewatin group, pre-Cambrian, Ontario: Collins, 247.

Keewatin series, pre-Cambrian, Lake Superior region: Lawson, 665.

Keewatin series, pre-Cambrian, Ontario: Miller, 787.

Keppel dolomites, Silurian, Ontario: Grabau, 427.

Kettle River formation, Oligocene, Washington, British Columbia: Daly, 278.

Kettle River formation, Tertiary (Oligocene), British Columbia : LeRoy, 680.

Keweenawan, pre-Cambrian, Canada: Wilson, 1304.

Keweenawan(?), pre-Cambrian, Ontario: Coleman, 237.

Keweenawan, pre-Cambrian, Ontario: Collins, 247 ; Parsons, 892.

Keweenawan, pre-Cambrian, Quebec: Bancroft, 36.

Keweenawan series, Cambrian or pre-Cambrian, Michigan: Laze, 655. 
Keweenawan (Nipigon), pre-Cambrian, Lake Superior region: Lawson, 665 .

Key Largo limestone, Pleistocene, Morida: Matson and Sanford, 768 .

Keyser member, Devonian, Maryland : Swartz et al., 1138.

Key West oolite, Pleistocene, Florida: Matson and Sanford, 768.

Kigluaik group, pre-Ordovician, Alaska : Moffit, 827 ; Smith, 1070.

Kintla formation, pre-Devonian, Montana and British Columbia: Daly, 278.

Kishenehn formation, Tertiary, Montana and British Columbia: Daly, 278.

Kitanning (lower) fire clay, Carboniferous, West Virginia: Hennen and Reger, 479.

Kitchener formation, Cambrian, Idaho, Montana, and British Columbia: Daly, 278.

Kitchener formation, pre-Cambrian, British Columbia : Schofleld, 1020.

Kitsalas formation, Trias (?), British Columbia : McConnell, 719.

Klusha intrusives, Tertiary (?), British Columbia : Cairnes, 158.

Knob Hill group, Carboniferous and postCarboniferous, British Columbia: LeRoy, 680.

Knox dolomite, Cambrian and Ordovician, Tennessee : Burchard, 135.

Knoydart formation, Devonlan, Nova. Scotia : Twenhofel, 1172.

Kokomo limestone, Silurian, Indiana: Kindle, 618.

Kootenai formation, Cretaceous, Alberta: Malcolm, $\mathbf{7 4 1 .}$

Kootenai formation, Cretaceous, Montana : Emmons and Calkins, 360 ; Pardee, 880 ; Stebinger, 1105.

Kootenay, Cretaceous, British Columbia, Alberta : Dowling, 326.

Kootenay coal measures, Cretaceous, Al. berta : Allan, 13.

Kootenay formation, Cretaceous, Alberta: Leach, 666.

Kootenay granite, Jurassic (?), British Columbia : Schofield, 1020.

Koyukuk group, Cretaceous or Jurassic, Alaska : Smith, 1068.

Kruger alkaline body, Tertiary?, Washington, British Columbia: Daly, 278.

Laberge series, Jura-Cretaceous, British Columbia : Cairnes, 158.

LaBiche shales, Cretaceous, Alberta: Malcolm, 741.

Lafayette (?) formation, Pliocene?, Florida: Matson and Sanford, 768.

Lafayette formation, Pliocene?, Virginia: Sanford, 1004.

Lafayette formation, Tertiary, Delaware: Matson, 766 .

Lake Agassiz silt, Quaternary, North Dakota: Leonard, 678.

rake Louise formation, Cambrian (Lower), Alberta, Britsh Columbia: Allan, 13.
Laketown dolomite, Silurian, Utah: Richardson, 975 .

Lance formation, Cretaceous or Tertiary, Montana: Rogers, 995.

Lance formation, Cretaceous or Tertiary, North Dakota: Leonard, 678.

Lance formation, Tertiary, Montana: Stebinger, 1105.

Langston limestone, Cambrian, Utah : Richardson, 975.

Las Cascadas agglomerate, Panama Canal Zone: MacDonald, 723, 726.

Lauientian, pre-Cambrian, Canada : Wilson, 1304, 1305.

Iaurentian, pre-Cambrian, Lake Superior region: Lawson, 665.

Laurentian, pre-Cambrian, Ontario: Burrows, 144 ; Coleman, 231, 237 ; Collins, 244, 247 ; Miller, 8115, 817, 820 ; Uglow, 1183.

Laurentian, pre-Cambrian, Quebec: Bancroft, 36 .

Laurentian system, pre-Cambrian, Ontario: Adams and Barlow, 8.

Laurie formation, pre-Cambrian, British Columbia : Daly, 279.

Lebo shale member, Tertiary, Montana : Rogers, 995, 996.

Leda clay, Pleistocene, Quebec: Stansfield, 1101.

Lennep sandstone, Cretaceous, Montana: Stebinger, 1105.

Leray member of Lowville formation, Ordovician, Ontario: Foerste, 378.

"Leroux formation," Triassic, Arizona : Robinson, 987.

Lévis formation, Ordovịcian, Quebec: Raymond, 951.

Lewis series, pre-Devonian, Montana and British Columbia: Daly, 278.

Lewistown limestone, Silurian, Pennsylvania: Grabau, 427.

Lightning Creek diorite, Miocene?, Washington, British Columbia: Daly, 278.

Lime Creek shales, Devonian, Missouri, Iowa : Keyes, 604.

Lisburne limestone, Carboniferous, Alaska : Smith, 1068.

Listmore formation, Pennsylvanian, Nova Scotia : Twenhofel, 117\%.

"Lithodendron formation," Triassic, Arizona : Robinson, 987.

Little River group, Carboniferous, New Brunswick: Young, 1347.

Lockatong (Gwynedd) shale, l'rias, Pennsylvania: Wherry, 1266.

Lockport dolomite, Silurian, New York: Kindle and Taylor, 619.

Lockport dolomite; Silurian, New York and Ontario: Schuchert, 1023.

Lockport dolomite, Silurian, Ontario: Parks, 887, 888.

Lockport formation, Silurian, ontario: Parks, 890 ; Williams, 1293.

Lockport (Niagara) limestone, Silurian, New York and Ontario: Taylor, 1149. 
I.ogan sills, pre-Cambrian, Ontario: Palsons, 892.

Lone Star formation, Cambrian, Idaho and British Columbia: Daly, 278.

Longwood shale, Silurian, New Jersey: Grabau, 427.

I oon River shales, Cretaceous, Alberta : Malcolm, 741.

Lorrain granite, pre-Cambrian, Ontarlo: Miller, 815, 817,820 .

Lorrain series, pre-Cambrian, Ontario: Collins, 244, 247.

Lorrain shale, Ordovician, Ontario: Cole$\operatorname{man}, 234,236$.

Lorraine, Ordovician, Ontario: Foerste, 378.

Iorraine formation, Ordovician, Ontario: Parks, 889, 890.

Lorraine group, Ordovlcian, Quebec, Ontario: Raymond, 952.

Lorraine (Frankfort) formation, Ordovician, Quebec: Raymond, 951.

Lostmans River limestone, Pleistocene, Flortda: Matson and Sanford, 768.

Loudoun formation, Cambrian, Virginla : Watson and Cline, 1244.

Louisiana limestone, Carboniferous, Missouri, Iowa : Keyes, 604.

rowerre quartzite, pre-Cambrian, New York: Kemp, 588.

Lowville formation, Ordovician, Ontario: Johnston, 568.

Lowville formation, Ordoviclan, Quebec, Ontario: Raymond, 952.

Lowville shales, Ordovician, Ontario: Foerste, 378.

L.oyalhanna limestone member, Mississipplan, Pennsylvania: Campbell et al., 169.

Iucas formation, Devonian, Iowa: Keyes, 610.

Lykins formation, Pennsylvanian and Permian, Colorado: Butters, $\mathbf{1 5 3 .}$

Lyman schists, New Hampshire: Lahēe, 644.

Lynx limestones, Cambrian, British Columbia and Alberta : Walcott, 1225.

I.yons formation, Pennsylvanian, Colorado: Butters, 153.

McAdam formation, Silurian, Nova Scotia : Twenhofel, 1172.

McAra's Brook formation, Mississippian, Nova Scotin: Twenhofel, 1172.

Maccrady formation, Carboniferous (Mississippian), Virginia: Stose, 1127.

MacDonald formation, Montana and British Columbia: Daly, 278.

McKenzie formation, Silurlan, Maryland, West Virginia: Grabau, 427.

McKim graywacke, pre-Cambrian, Ontario: Coleman, 237.

McLeansboro formation, Pennsylvanian, Illinois: Shaw and Savage, 1042.

McNaughton sandstones, Cambrian, British Columbia and Alberta: Walcott, 1225.
Madison limestone, Carboniferous, Montana : Knopf, 626.

Madison llmestone, Carboniferous (Mississippian), Montana : Pardee, 880.

Madison limestone, Mississipptan, Idaho: Schultz and Richards, 1030.

Madison limestone, Mississippian, Montana : Emmons and Calkins, 360.

Madison limestone, Mississippian, Utah : Richardson, 975.

Mahoning horizon, Carboniferous, Ohio: Condit, 251.

Mahonlng sandstone, Carboniferous, West Virginia: Hennen and Reger, 479; Krebs and Teets, 640 .

Mahoning sandstone member, Pennsylvanian, Pennsylvania : Campbell et al., 169.

Mahto sandstones, Cambrian, British $\mathrm{Co}$ lumbia and Alberta: Walcott, 1225.

Malden sandstone, Carboniferous, West Virglnia : Krebs and Teets, 640.

Malignant Cove formation, Ordoviclan?, Nova Scotia : Twenhofel, 1172.

Mancos shale, Cretaceous, New Mexico: Lee, 671.

Manhattan schist, pre-Camblian, New York : Kemp, 588.

Manitoba, Devonian, Manitoba: McLean, 736.

Manitoban, Devonian, Manitoba: Dowling, 326.

Manitoulin member, Silurian, Ontarlo : Williams, 1291.

Mannington sandstone, Carboniferous, West Virginia: Hennen nnd Reger, $479 ;$ Krebs and Teets, 640 .

Maquoketa beds, Ordovician, Iowa : Slocum, 1057.

Marble Bay formation, upper Paleozoic, British Columbia: Bancroft, 35.

Marble Canyon limestone, Carboniferous, British Columbia: Drysdale, 331.

Marcellus black shale member, Devonian, Maryland: Prosser et al., 937.

Marlanna limestone, Oligocene, Florida, Matson and Sanford, 768 .

Marietta (lower) sandstone, Carbonlferous. West Virginia: Hennen and Reger, 479; Krebs and Teets, 640 .

Marletta (upper) sandstone, Carboniferous, West VIrginla: Hennen and Reger, 479.

Marsh shale, Algonkian, Montana: Knopf, 626.

Martlnsburg shale, Ordovician, Pennsylvanila: Grabau, 427.

Matagami serles, pre-Cambrian, Quebec: Bancroft, 36 .

Mauch Chunk formation, Mississipplan, Pennsylvania: Barrell, 45; Campbell et al., 169.

Mauch Chunk series, Mississippian, West Virginia: Fennen and Reger, 479.

Maxfield formation, Ordovician, Utah : Hintze, 507.

Maxville limestone, Carboniferous, Michlgan : Gregory, 442, 
Maysville limestone, Wisconsin: Gribau, 427.

Maywood clays, Pleistocene, British Columbia : Clapp, 199.

Maywood formation, Silurian (?), Montana: Emmons and Calkins, 360.

Meagher limestone, Cambrian, Montana: Knopf, 626.

Medina beds, Silurian, Great Lakes region: Grabau, 427.

Medina formation, Ordovician, Ontario: Parks, 887, 888.

Medina formation, Silurian, New York and Ontario: Schuchert, 1023.

Medina group (lower part), Ordovician or Silurian, New York: Kindle and Taylor, 619.

Medina group (upper part), Silurian, New York: Kindle and Taylor, 619.

Medina sandstone, New York and Ontario: Taylor, 1149.

Mendez formation, Cretaceous, Mexico: White, 1275.

Nerced formation, Miocene, Pliocene, California, Oregon, Washington : Arnold and Hannibal, 18.

Mercer (lower) limestone, Carboniferous, West Virginia: Hennen and Reger, 479.

Mesaverde formation, Cretaceous, Colorado: Woodruff, 1325 .

Mesaverde formation, Cretaceous, New Mexico: Lee, 671.

Metchosin volcanics, Eocene, British Columbia: Clapp, 199.

Meteor granodiorite, Washington: Weaver, 1251.

Miami oolite, Pleistocene, Florida : Matson and Sanford, 768 .

Midway volcanic group, Miocene, Washington, British Columbia: Daly, 278.

Midway volcanic group, Tertiary (Miocene), British Columbia: LeRoy, 680 .

Miette sandstones, pre-Cambrian, British Columbia and Alberta: Walcott, 1225.

Millwood, Cretaceous, Manitoba: Dowling, 326.

Millwood shales, Cretaceous, Manitoba : Malcolm, 741.

Mispeck formation, Carboniferous, New Brunswick : Young, 1347.

Modelo formation, Tertiary, California: Louderback, 703 .

Moencopie formation, Permlan?, Arizona : Robinson, 987.

Monk formation, pre-Cambrian, Idaho and British Columbia : Daly, 278.

Monongahela series, Carboniferous, West Virginia : Hennen and Reger, 479; Krebs and Teets, 640.

Monroe beds, Silurian, Michigan: Grabau, 427.

Monroe formation, Silurian, Ontario : Parks, 886, 887, 890.

Moose metargillite, pre-Cambrian, British Columbia : Daly, 279.
Monterey formation, Oligocene-Miocene, California, Oregon, Washington : Arnold and Hannibal, 18.

Monterey series, California: Kew and Stoner, 597.

Monterey series, Tertiary, California : Louderback, 703.

Morehouse quartzite, Ordovician and Silurian?, Utah : Butler, 147.

Morgan formation, Utah: Hintze, 507.

Morgantown sandstone, Carboniferous, Ohio: Condit, 251.

Morgantown sandstone, Carboniferous, West Virginia: Hennen and Reger, 479 ; Krebs and Teets, 640 .

Morgantown sandstone member, Pennsylvanian, Pennsylvania: Campbell et al., 169.

Morrison formation, Jurassic, Colorado: Butters, 153 ; Grout et al., 450.

Mount Hope formation, Pleistocene, Panama: Brown and Pilsbry, 115.

Mount Morris limestone, Carboniferous, West Virginia: Hennen and Reger, 479.

Mount Roberts formation, Carboniferous?, British Columbia: LeRoy, 680.

Mount Roberts formation, Carboniferous and post-Carboniferous, British Columbia : LeRoy, 680.

Mt. Savage fire clay, Carboniferous, West Virginia : Hennen and Reger, 479.

Mount Stevens group, pre-Devonian, British Columbia: Cairnes, 158.

Mt. Whyte formation, Cambrian (Lower), Alberta, British Columbia: Allan, 13.

Mowitza shale, Devonian, Utah: Butler, 147.

Moydart formation, Silurian, Nova Scotia : Twenhofel, 1172.

Moyie formation, Cambrian, Idaho, Montana, and British Columbia : Daly, 278.

Moyie sills, Idaho, British Columbia: Daly, 278.

Mimm limestones, Cambrian, British Columbia and Alberta: Walcott, 1225.

Murphy marble, Cambrian, Georgia: La Forge and Phalen, 643.

Nakimu limestone, pre-Cambrian, British Columbia : Daly, 279.

Nanaimo series, Cretaceous, British Columbia: Clapp, 199.

Nanjemoy formation, Eocene, Virginia : Sanford, 1004.

Nantahela slate, Cambrian, North Carolina, Georgia : La Forge and Phalen, 643.

Napoleon sandstone, Carboniferous, Michigan: Gregory, 442.

Nashua marl, Fliocene, Florida: Matson and Sanford, 768 .

Nebraskan difift, Quaternary: Deeley, 304:

Neihart quartzite, Algonkian, Montana: Emmons and Calkins, 360 .

Nelson batholith, Jurassic?, British Columbia : LeRoy, 680.

Newcastle formation, Cretaceous (Upper), British Columbia: Clapp, 199. 
New Glasgow conglomerate, Nova Scotia: Young, 1347.

Newland formation, Algonkian, Montana : Emmons and Calkins, 360.

Newman limestone, Carboniferous, Tennessee : Burchard, 1.35 .

Newman limestone, Carboniferous (Mississippian), Virginia : Stose, 1127.

New Scotland member, Devonian, Maryland: Swartz et al., 1138.

Niagara Falls moraine, Quaternary, New York: Kindle and Taylor, 619.

Niagara group, Silurian, New York: Kindle and Taylor, 619.

Nicola formation, Jurassic-Triassic, British Columbia: Drysdale, 331.

Nineveh limestone, Carboniferous, West. Virginia: Hennen and Reger, 479.

Nineveh sandstone, Carboniferous, West Virginia: Hennen and Reger, 479.

Niobrara, Cretaceous, Manitoba, Saskatchewan : Dowllng, 326.

Niobrara formation, Cretaceous, Alberta, Manitoba, Saskatchewan: Malcolm, 741.

Niobrara formation, Cretaceous, Colorado: Grout et al., 450 .

Nlobrara formation, Cretaceous, North Dakota: Leonard, 678.

Niobrara limestones, Cretaceous, Iowa: lieyes, 609.

Nipigon, pre-Cambrian, Ontario: rarsons, 892.

Nipissing diabase, pre-Cambrian, Ontario : Collins, 247 ; Miller, 815, 817, 820.

Nishnabotna sandstones, Cretaceous, Iowa : Keyes, 609 .

Noatuk sandstone, Carboniferous, Alaska : Smith, 1068.

Noblesville dolomite, Silurian, Indiana : Kindle, 618 .

Noix oolite member, Silurian, Illinois and Missouri: Savage, $1.007,1.008$.

Nome group, Paleozoic, Maska : Moffit, 827.

Nora limestone, Devonian, Iowa: Thomas, 1.1 .55 .

Norian series, pre-Cambrian, Canada : Wilson, 1305.

Northumberland. formation, Cretaceous (Upper), British Columbia: Clapp, 199.

Nottely quartzite, Cambrian, North Carolina, Georgia : La Forge and Phalen, 643.

Nounan limestone, Cambrian, Utah: Richardson, 975 .

Nugget sandstone, Jurassic or Triassic, Idaho: Schultz and Richards, 1.030 .

Oak Grove sand member, Oligocene, Florida: Mitson and Sanford, 768.

Ocala limestone, Oligocene, Florida: Wat son and Sanford, 768 .

Oceanic beds, Barbados: Cunningham-Craig, 270.

Odanah, Cretaceous, Manitoba: Dowling, 326.

Odanah formation, Cretaceous, Manitoba : Malcolm, 741 .
Ogden quartzite, Algonquin and Cambrian, Utah : Hintze, 507.

Ogden quartzite, Cambrian, utah: Lough. lin, 706 .

Ohio sha'e, Devonian, Ohio: Prosser, 932.

Olequa formation, Eocene, Washington: Arnold and Fannibal, 18.

Oljato sandstone member, Triassic, Utah : Giregory, 446.

Onaping tuff, pre-Cambrian, Ontario: Coleman, 231. 237.

Oneida conglomerate, Sllurian, New York: Grabau, 427.

Oneonta formation, Devonian, New York: Barrell, 45.

Onondaga formation, Devonian, Ontario : Parks, 886, 887, 890

Onondaga limestone, Devonian, New York: Kindle, 616; Kindle and Taylor, 6.19.

Onondaga limestone, Devonian, Ontario: Stauffer, 1102, 1103.

Onondaga shale member, Devonian, Maryland: Prosser et al., 937.

Cntarian, pre-Cambrian, Lake Superior region: Lawson, 665.

Contarian system, pre-Cambrian, Canada: Wilson, 1304

Onwatin slate, pre-Cambrian, Ontario: Coleman, 231, 237.

Open Bay group, upper Paleozoic, British Columbia: Bancroft, 35 .

Orca group, l'aleozoic, Alaska: Capps and Johnson, 1.78 .

Orindan formation, Tertiary, California : Merriam, 792.

Oriskany formation, Jevonian, Maryland : l'rosser et al., 937 ; Swartz et al., 1138.

Oriskany sindstone, Devonjan, New York: Kinule, 616.

Oriskauy sandstone, Devonian, Ontario: Farks, 886, 887, 890 ; Stauffer, 1102.

Osoyoos batholith, Jurassic, Washington, British Columbia: Daly, 278.

Oswayo formation, Mississippian, New York: Barrell, 45.

Oswego sindstone, Ordovician, New York: Girabait, 427.

Ottawa gneiss, pre-Cambrian, Quebec: Stansfield, 1101.

Ottawa series, pre-Cambrian, Canada: Wilson, 1305.

Ottel: granite, Tertiary, British Columbia: Camsell, 170.

Ottertail Jimestone, Cambrian (upper), British Columbia: Allan, 13.

Ouray limestone, Devonian-Mississippian, Colorado: Crawford, 266.

l'aget formation, Cambrian (Upper), Brit. ish Columbia: Allan, 13.

Palm Beach limestone, Pleistocene, Florlda : Matson and Sanford, 768.

Pamelia formation, Ordovician, Quebec, Ontario : Raymond, 952.

Pamunkey group, Eocene, Virginia: San. ford, 1004

$$
38416^{\circ}-\text { Bull. } 584-14-12
$$


Panama formation, Oligocene, Panama Canal Zone: MacDonald, 723, 726.

Paradise limestone, Silurian, Utah : Hintze, 507.

Park granite stock, Tertiary, Washington, British Columbia: Daly, 278.

Park shale, Cambrian, Montana: Knopf, 626.

Park City limestone, Pennsylvanian or Permian, Utah : Hintze, 507.

Parkhead sandstone, Devonian; Maryland : Swartz, 1137.

Parma sandstone, Carboniferous, Michigan: Gregory, 442.

Parson Bay group, Triassic, British Columbia : Bancroft, 35.

Pasayten andesite, Cretaceous, Washington, British Columbia: Daly, 278.

Pasayten series, Cretaceous, Washington, British Columbia: Daly, 278.

Pasayten volcanic formation, Cretaceous, Washington, British Columbia : Daly, 278.

Paskapoo, Tertiary, Saskatchewan, Alberta: Dowling, 326.

Paskapoo series, Cretaceous, Alberta : Malcolm, 741.

Patapsco formation, Cretaceous, Delaware: Matson, 766 .

Patapsco formation, Cretaceous, Virginia : Sanford, 1004.

Fatton? shale member, Mississippian, Pennsylvania : Campbell et al., 169.

Patuxent formation, Cretaceous, Virginia : Sanford, 1004.

Payette formation, Tertiary, Idaho : Bowen, 01.

Peace River sandstones, Cretaceous, Alberta: Malcolm, 741 .

Pelican sandstone, Cretaceous, Alberta: Malcolm, 741.

Pelican shale, Cretaceous, Alberta: Malcolm, 741.

Pembroke formation, Silurian, Maine: Bastin and Williams, 56; Williams, 1289.

Pend d'Orellle group, Carboniferous?, Britist Columbia : LeRoy, 680.

Pend d'Oreille group, Washington, British Columbia: Daly, 278.

"Peninsular" limestone, Oligocene, Florida: Matson and Sanford, 768.

Perkins group, upper Paleozoic, British Columbia : Cairnes, 158.

Perry formation, Devonian, Maine: Bastin and Williams, 56.

Perry formation, Silurian, Maine: Williams, 1289.

Phillips formation, Cambrian?, British Columbia: Schofield, 1.020.

Phillips formation, Montana and British Columbia: Daly, 278.

Phoenix volcanic group, Mesozoic?, Washington, British Columbia : Daly, 278.

Phosphoria formation, Permian?, Idaho: Schultz and Richards, 1030.

Phosphoria formation, Permian?, Utah : Richardson, 975.
Pierre, Cretaceous, Manitoba, Saskatchewan : Dowling, 326.

Pier're formation, Cretaceous, Colorado: Grout et al., 450.

Pierre shale, Cretaceous, North Dakota: Leonard, 678.

Pierre shales, Cretaceous, Alberta: Dowling, 327.

Pilgrim limestone, Cambrian, Montana : Knopf, 626.

Pine Creek limestone, Carboniferous, West Virginia: Hennen and Reger, 479; Krebs and Teets, 640.

Pittsburg limestone, Carboniferous, Ohio: Condit, 251.

Pittsburgh limestone, Carboniferous, West Virginia: Krebs and Teets, 640.

Pittsburgh red shale, Carboniferous, West Virginia: Hennen and Reger, 479; Krebs and Teets, 640.

Pittsburgh sandstone, Carboniferous, West Virginia: Hennen and Reger, 479.

Pittsburgh (lower) limestone, Carboniferous, West Virginia: Hennen and Reger, 479 .

Pittsburgh (lower) sandstone, Carboniferous, West Virginia: Hennen and Reger, 479 ; Krebs and Teets, 640.

Pittsburgh (upper) sandstone, Carboniferous, West Virginia: Krebs and Teets, 640.

Pittsford shale, Silurian, New York: Grabau, 427.

Pocono formation, Mississippian, Pennsylvania: Campbell et al., 169.

Pocono sandstone, Mississippian, Appalachian region: Barrell, 45.

Pocono series, Mississippian, West Virginia: Hennen and Reger, 479.

Point Edward formation, Carboniferous (Pennsylvanian), Nova Scotia: Hyde, 543.

Pomeroy quartz monzonite, Colorado: Crawford, 266

Pomeroy sandstone, Carboniferous, IVest Virginia: Krebs and Teets, 640.

Ponca sandstone, Cretaceous, Iowa: Keyes, 609.

Pontiac group, pre-Cambrian, Quebec: Bancroft, 36.

Poquag quartzite, pre-Cambrian, New York: Kemp, 588.

Porcupine Hill beds, Cretaceous, Aiberta: Malcolm, 741 .

Portage formation, Devonian, New York: Barrell, 45.

Portersville horizon, Carboniferous, Ohio: Condit, 251.

Portersville limestone or shale, Carboniferous, Ohio: Mark, 747.

Potomac group, Cretaceous, Virginia : Sanford, 1004.

Potsdam sandstone, Cambrian, Quebec: Raymond, 952 .

Pottsville formation, Pennsylvanian, Illinois: Shaw and Savage, 1042. 
Pottsvllle formation, Pennsylvanian, Pennsylvania : Campbell et al., 169.

Pottsville series, Carboniferous, West Virginia: Hennen and Reger, 479; Krebs and Teets, 640.

Pottsville (upper), Carboniferous, West Virginia : Krebs and Teets, 640 .

Pre-Wisconsin drift, Quaternary, New York : Kindle and Taylor, 619.

Price sandstone, Carboniferous, Mississippian, Virginia: Stose, 1127.

Prichard quartzite, Algonkian, Montana: Emmons and Calkins, 360.

Priest River terrane, Idaho, Washington, British Columbia : Daly, 278.

Prince Rupert formation, upper Paleozole?, British Columbia: McConnell, 719.

Irinceton batholith, Colorado: Crawford, 266.

I'rinceton quartz monzonite, Colorado: Crawford, 266.

I'roctor sandstones, Carboniferous, West Virginia: Hennen and Reger, 470.

1 rotection formation, Cretaceous (Upper), British Columbia: Clapp, 199.

I'rout limestone, Devonian, Ohlo: Prosser, 932.

P.urcell lava, Cambrian?, British Columbia : Schofield, 1020.

l'urcell lava formation, Montana and British Columbial Daly, 278.

l'urcell series, Idaho, Montana, and British Columbia: Daly, 278.

Purcell sills, Cambrian?, British Columbia : Schofield, 1020

I'uyallup epoch (interglaclal), Pleistocene, Washington: Bretz, 101.

I'uyallup interglacial deposits, F'leistocene, British Columbia : Clapp, 199.

Quadrant formation, Pennsylvanian, Montana: Emmons and Calkins, 360 ; Pardee, $8 \mathrm{SO}$

Quadrant quartzite, Carboniferous, Montan: : Knopf, 626 .

Quartermaster formation, Fermian, Oklahoma : Snider, 1078

Quebec City formation, Ordovician, Quebec: Raymond, 951 .

Queen Charlotte Islands formation, Cretaceous, British Columbia: Drysdale, 331.

Queenston formation, Ordovician, New York and Ontario: Schuchert, 1023.

Queenston member, Ontario: Parks, 888.

Queenston shale, Ordovician or Silurian, New York: Kindle and Taylor, 619.

Queenston shales, New York: Grabiu, 427.

Quoddy shale, Silurian, Maine: Bastin and Williams, 56 ; Williams, 1289

Rapid formation, Devonian, Iowa: Keyes, 610.

IRamsay Lake quartzite, pre-Cambrian, Ontario : Coleman, 237.

Raritan formation, Cretaceous, Delaware: Matson, 766 .

Raton formation, lecene, Colorado and New Mexico: Knowlton, 632; Lee, 671.
Ravalli formation, Algonkian, Montana : Emmon's and Calkins, 360 .

Rawhide formation, Carboniferous?, British Columbia : LeRoy, 680.

Rawhide formation, Carboniferous and post. Carboniferous, British Columbia: LeRoy, 680

Reade formation, Mississippian, Utah : Hintze, 507.

Red Head formation, Carboniferous, New Brunswick: Young, 1347.

Red Lion formation, Cambrian, Montana : Billingsley, 75 ; Emmons and Calkins, 360 .

Redstone limestone, Carboniferous, West Virginia: Hennen and Reger, 479.

Redwall limestone, Missisipplan, Arjzona : Robinson, 987.

Red Warrior limestone, Silurian? and Do vonian?, Utah : Butler, 147.

Remmel batholith, Jurassic, Washington, British Columbia: Daly, 278.

Rensselaer grit, Devonian, New York, Massachusetts : Barrell, 45.

Rex chert member, Permian(?), Idaho: Schultz and Richards, 1030.

Richmond, Ordovician, Ontario: Foerste 378.

Richmond formation, Ordovician, Ontario Parks, 889, 890.

Richmond group, Ordovician, Quebec, On tario: Raymond, 952.

Richter Mountain hornblendite, Carboniferous?, Washington, British Columbla: Daly, 278.

Iidgely sandstone member, Devonian, Maryland: Swartz et al., 1138.

Ripple formation, Cambrian, Idaho and British Columbia: Daly, 278.

Riverdale formation, Nova Scotia: Hyde, 543.

Riverside sands, Tertlary, Iowa: Keyes, 611.

Robson llmestones, Ordovician, British Columbia and Alberta: Walcott, 1225.

Rochester shale, Silurian, New York and Ontario: Schuchert, 1023.

Rochester shale, Silurian, Ontario: Parks, 887,888 .

Rochester shale member, Silurian, New York: Kindle and Taylor, 619 .

Rock Creek chonolith, Jurassic, Washing. ton, British Columbia: Daly, 278.

"Rockwood" formation, Silurian, Tennessee: Burchard, 135.

Rocky Mountain quartzite, Pennsylvanian, Alberta: Allan, 13; Shimer, 1145.

Romney formation, Devonian, Maryland.: Prosser et al., 937.

Roosville formation, Cambrian?, British Columbia : Schofield, 1020.

Roosville formation, Montana and British Columbia : Daly, 278.

Ross quartzite, pre-Cambrian, Britisl Co lumbia : Daly, 279. 
Ross Brook formation, Silurian, Nova Scotia : Twenhofel, 1172.

Rossland alkali granite, Tertiary, British Columbia : LeRoy, 680.

Rossland group, Carboniferous and postCarboniferous, British Columbial LeRoy, 680.

Rossland monzonite, Washington; British Columbia : Daly, 278.

Rossland volcanic group, Washington, British Columbia: Daly, $27 \mathrm{~S}$.

Rossland Mountain group, Washington, British Columbia: Daly, 278.

Round Knob horizon, Carboniferous, Ohio: Condit, 251.

Rush Run sandstone, Carboniferous, West Virginia: Hennen and Reger, 479.

Rykert granite batholith, Jurassic?, Washington, Idaho, British Columbia: Daly, 278.

Saanich formation, Pleistocene, Washington and British Columbia: Arnold and Hannibal, 18.

Saanich granodiorite, Mesozoic, British Columbia : Clapp, 199.

Saginaw coal series, Carboniferous, Michigan : Gregory, 442.

St. Alban beds, Devonian, Quebec : Clarke : 213.

St. Charles limestone, Cambrian, Utah : Richardson, 975 .

St. Cloud sandstone, Carboniferous, West Virginia: Hennen and Reger, 479.

St. John group, Cambrian and Ordovician, New Brunswick: Young, 1347.

St. Mary River beds, Cretaceous, Alberta : Malcolm, 741.

St. Mary River series, Cretaceous or Tertiary?, Alberta : Dowling, 327.

St. Mary's formation, Miocene, Virginia : Sanford, 1004.

St. Piran formation, Cambrian' (Lower), Alberta, British Columbia: Allan, 13.

Salina beds, Silurian, Ontario: Stauffer, 1102.

Salina deposits, Silurian, New York, Michi. gan: Grabau, 427.

Salina formation, Silurian, New York: Kindle and Taylor, 619 .

Salina formation, Silurian, Ontario: Parks, 887.

Salmon Arm schist member, pre-Cambrian, British Columbia: Daly, 279.

Salmon River sandstone, Ordovician, New York: Grabau, 427.

Saltsburg sandstone, Carboniferous, West Virginia: Hennen and Reger, 479 ; Krebs and Teets, 640 .

Saltsburg sandstone member, Pennsylvanian, Pennsylvania : Campbell et al., 169.

San Felipe series, Cretaceous, Mexico: White, 1275.

Sangamon soil, Quaternary, Illinois: Shaw and Savage, 1042.

Sangamon soll and loess, Quaternary: Deeley, 304 .
San Lorenzo formation, Oligocene, Washington: Arnold and Hannibal, 18.

San Pablo formation, California: Clark, 207.

Santa Fe marls, Tertiary, New Mexico: Henderson, 478

Saverton shales, Carboniferous, Missouri, Iowa: Keyes, 604.

Sawatch quartzite, Cambrian, Colorado: Crawford, 266.

Sawback formation, Devonian, Alberta : Allan, 13.

Scarboro beds, Pleistocene, Ontario: Cole$\operatorname{man}, 234, \cdot 236$.

Scotland beds, Tertiary?, Barbados: Cunningham-Craig, 270.

Seattle formation, Oligocene, Washington and Oregon: Arnold and Hannibal, 18.

Seine series, pre-Cambrian, Ontario: Uglow, 1183

Selkirk series, Cambrian?, British Columbia : LeRoy, 680

Selkirk series, pre-Cambrian, British Columbia : Daly, 279.

Senecan group, Devonian, New York, Pennsylvania: Barrell, 45.

Sequatchie formation, Silurian, Appalachian Valley: Ulrich, 1187.

Sergeant shales, Cretaceous, Iowa: Keyes, 609.

Sespe formation, Tertiary, California : Louderback, 703.

Sevier shales, Ordovician, Tennessee: Grabau, 427 .

Sewickley limestone, Carboniferous, West Virginia: Hennen and Reger, 479

Sewickley (lower) sandstone, Carboniferous, West Virginia: Flennen and Reger, 479.

Sewickley (upper) sandstone, Carboniferous,' West Virginia: Hennen and Reger, 479.

Sexton Creek (Brassfield) limestone, Silurian, Illinois and Missouri: Savage, 1007, 1008.

Seymour formation, Pleistocene, Texas : Gordon, 416.

Sharon conglomerate, Carboniferous, West Virginia: Hennen and Reger, 479.

Shawangunk conglomerate, Silurian, -New York, Pennsylvania: Grabau, 427.

Sheppard formation, pre-Devonian, Montana and British Columbia: Daly, 278.

Sheppard granite, Eocene?: Daly, 278.

Sherbrooke formation, Cambrian (Upper), British Columbia: Allan, 13.

Shinarump clay, Triassic, Utah : Lawson, 663.

Shinarump conglomerate, Triassic, Arizona, Utah, Colorado, New Mexico: Gregory, 446.

Shinarump conglomerate, Triassic, Utah : Lawson, 663 .

Shinarump group, Triassic, Utah : Lawson, 663 . 
Shinarump group, Triassic and Permian, Arizona : Robinson, 987 .

Shoal River marl member, Oligocene, Florida: Matson and Sanford, 768.

Shriver chert member, Devonian, Maryland: Swartz et al., 1138.

Shulie formation, Carboniferous, Nova Scotia : Bell, 64.

Shuswap series, pre-Cambrian, British Columbia: Daly, 279; LeRoy, 680.

Sicamous limestone, pre-Cambrian, British Columbia: Daly, 279.

Siestan formation, Tertiary; California : Merriam, 792.

Sillery formation, Cambrian or Ordorician, Quebec: Young, 1347.

Silfery formation, Ordovician, Quebec: Raymond, 951 .

Silver IIill formation, Cambrian, Montana : Billingsley, 75; Emmons and Calkins, 360 .

Similkameen batholith, Tertiary, Washington, British Columbia: Daly, 278.

Sir Donald formation, Cambrian, Britis! Columbia : Daly, 279.

Siyeh formation, Cambrian?, British Columbia : Schofield, 1020.

Siyeh formation, Cambrian, Montana and British Columbia: Daly, 278.

Skagit harzburgite, Oligocene?, Washington, British Columbia : Daly, 278.

Skagit volcanic formation, Oligocene? Washington, British Columbia: Daly, 278.

Skecna formation, Cretaceous, British Columbia: McConnell, 719.

Skelley limestone, Carboniferous, Ohio: Condit, 251 ; Mark, 747.

Skunnemunk conglomerate, Devonian, New Jersey, New York: Barrell, 45.

Slesse diorite, Miocene?, Washington, British Columbia: Daly, 278 .

Slocan series, Carboniferous?, British Columbia : LeRoy, 680.

Smelter granite stock, .Turassic, Washington, British Columbia: Daly, 278 .

Smoky River shales, Cretaceous, Alberta : Malcolm, 741 .

Smoky River shales, Cretaceous, British Columbia : Galloway, 394.

Snyder shales, Devonian, Missouri, Iowa : Keyes, 604.

Sodus shale, Silurian, New York: Grabau, 427.

Sodus shale member, Silurian, New York: Kindle and Taylor, 619.

Soledad beds, Cretaceous, Mexico: Haarman, 453.

Solon formation, Devonian, Iowa: Keyes, 610.

Sooke formation, Oliogocene, Wașhington and British Columbia: Arnold and Hannibal, 18.

Spence shale member, Cambrian, Utah: Richaldson, 975.
Spence's Bridge volcanic group, Turassic. Cretaceous, British Columbia: Drysdale, 331.

Spokane formation, Algonkian, Montana : Emmons and Calkins, 360.

Spokane shale, Algonkian, Montana : Knopf, 626.

Spokane shale, pre-Cambrian, Montana: Billingsley, 75.

Springvale sindstone, Devonlan, Ontario: Stauffer, 1102, 1103.

Steeprock series, pre-Cambrian, ontario: Uglow, 1183.

Stephen formation, Cambrian (Middle), Alberta, British Columbia: Allan, 13.

Stockton (Norristown) sandstone, Jirias, Pennsylvania : Wherry, 1266.

Stonehouse formation, Sllurian, Nova Scotia : 'Twenhofel, $\mathbf{1 1 7 2 .}$

Stony Mountain formation, Ordovician, Manitoba: Dowling, 326 ; Malcolm, 741 ; Wallace, 1230.

Strawn formation. Carboniferous, Texas : Gordon, 41.6.

Sudbury norite, pre-Cambrian, Ontarlo: Collins, 247 ; Miller, 820.

Sudbury series, pre-Cambrian, Ontario: Coleman, 231, 237; Collins, 247.

Sumas granite and diorite, Turassic?, Wnshington, British Columbia: Daly, 278.

Summerfield limestone, Carboniferous, Ohio : Condit, 251.

Summit series, Cambrian and pre-Cambrian. Idaho and British Columbla: Daly, 278.

Sundance formation, Colorado: Butters, 153.

Sunderland formation, Pleistocene, Virginia: Sanford, 1004 .

Supai formation, Pennsylvanian, Arizona : Robinson, 987.

Sutton formation, Jurassic and Triassic?, British Columbia: Clapp, 199.

Swan Peak quartzite, Ordovician, Utah : Richardson, 975 .

Swift Water series, New Fampshire: Lahee, 644.

Sylvania sandrock, Silurian, Ontario: Parks, 890 .

Sylvania sandstone, Silurian, Ontario : Parks, 886, 887, 890.

Tah formation, Cambrian, British Columbia and Alberta: Walcott, 1225.

Taku group, Devonian (?), Britlsi Columbia: Cairnes, 158 .

Talbot formation, Pleistocene, Virginia Sanford, 1004.

Talisman quartzite. Carboniferous (Pennsylvanian?). Utah : Butler, 147.

Tamasopa limestone, Cretaceous, Mexico: White, 1275 .

Tamihy series, Cretaceous?, Washington, British Columbia: Daly, 278.

Tampa formation, Oligocene, Florida : Matson and Sanford, 768; Sellards and Gunter, 1038. 
Tantalus conglomerate, Jura-Cretaceous, British Columbia: Cairnes, 158.

- Tar sands, Cretaceous, Alberta: Malcolm, 741.

Tatalina group, Ordovician?, Alaska: Prindle, 929.

Tatay limestones, Cambrian, British Columbia and Alberta: Walcott, 1225.

Taylor sandstone, Carboniferous, West Virginia: Hennen and Reger, 479.

Tejon formation, Eocene, California : Dickerson, 314.

Tejon series, Eocene, Oregon and Washington: Arnold and Hannibal, 18.

Tellico sandstone, Ordovician, Tennessee: Burchard, 135.

Temiskaming. See Timiskaming.

Tensleep sandstone, Pennsylvanian, Wyoming: Blackwelder, 76 .

Thaynes limestone, Triassic, Idaho: Schultz and Richards, 1030.

Theresa formation, Ordovician, Quebec, Ontario: Raymond, 952.

Thetford series, pre-Cambrian?, Quebec: Harvie, 466.

Thornton fire clay, Carboniferous, West Virginia: Hennen and Reger, 479.

Thorold quartzite, Silurian, New York, Ontario: Grabau, 427.

Thorold sandstone, Silurian, New York: Kindle and Taylor, 619.

Threeforks limestone, Devonian, Utah : Richardson, 975.

Threeforks shale, Devonian, Montana: Inopf, 626.

Tigaraha schist, F'aleozoic, Alaska : Mofft, 827.

Timiskaming series, pre-Cambrian, Ontario : Burrows, 144; Coleman, 231; Collins, 247 ; Miller, 815, 817, 820 .

Titkana limestones, Cambrian, British Columbia and Alberta: Walcott, 1225.

Tomichi limestone, Ordovician, Colorado: Crawford, 266.

Tonkawatla formation, pre-Cambrian, British Columbia: Daly, 279.

Tonzona group, Devonian and Silurian?, Alaska : Prindle, 929.

Topache limestone, Carboniferous (Mississippian?), Utah : Butler, 147.

Topatopa formation, Tertiary, California : Louderback, 703.

Toronto formation, Pleistocene, Ontario: Coleman, 234, 236.

Totsen series, Silurian, Alaska : Maddren, 739.

Tranquille beds, Miocene?, British Columbia: Drysdale, 331.

Trenton, Ordovician, Ontario and Quebec: Raymond, 958.

Trenton formation, Ordovician, New York et al.: Grabau, 427.

Trenton formation, Ordovician, Ontario: Parks, 890

Trenton formation, Ordovician, Quebec: Raymond, 951.
Trenton group, Ordovician, Quebec, Ontario: Raymond, 952 .

Trenton (Curdsville), Ordovician, Ontario: Foerste, 378.

Trout Lake conglomerate, pre-Cambrian, Ontario: Coleman, 231, 237.

Tshinakin formation, pre-Cambrian, British Columbia: Daly, 279.

Tulameen group, Triassic?, British Columbia : Camsell, 170

Juscaloosa formation, Cretaceous, Alabama: Berry, 731 .

Tuscarora quartzite, Silurian, Pennsylvania: Grabau, 427.

Tusquitee quartzite, Cambrian, North Carolina, Georgia: La Forge and Phalen, 643.

Twin Creek limestone, Jurassic, Idaho: Schultz and Richards, 1030 .

Twin River formation, Oligocene; Washington: Arnold and Hannibal, 18.

Uffington shale, Carboniferous, West Virginia: Hennen and Reger, 479.

Union formation, Nova Scotia: Hyde, 543. Uniontown limestone, Carboniferous, West Virginia: Hennen and Reger, 479; Krebs and Teets, 640

Uniontown sandstone, Carboniferous, West Virginia: Hennen and Reger, 479; Krebs and Teets, 640 .

Ute limestone, Cambrian, Utah: Richardson, 975 .

Ute limestone, Mississippian, ljtah: Loughlin, 706 .

Ute limestone, Silurian, Utah: Hintze, 507.

Utica formation, Ordovician, Ontario: Parks, 890

Utica formation, Ordovician, Quebec: Raymond, 951

Utica formation, Ordovician, Quebec, Ontario: Raymond, 952.

Litica group, Ordovician, Quebec, Ontario : Raymond, 952.

Utica shale, Ordovician, New York et al.: Grabau, 427.

Valdes group, Triassic(?), British Columbia: Bancroft, 35.

Valdez group, Paleozoic, Alaska : Capps and Johnson, 178.

Valhalla granite, Tertiary, British Columbia : LeRoy, 680 .

Valleytown formation, Cambrian, Georgia : La Forge and Phalen, 643.

Vancouver group, Jurassic and Triassic?, British Columbia: Clapp, 199.

Vancouver series, Carboniferous and Triassic(?), Vancouver Island, B. C.: Arnold and Hannibal, 18.

Vanport (ferriferous) limestone, Carboniferous, West Virginia: Hennen and Reger, 479.

Vaqueros formation, Tertiary, California : Louderback, 703 .

Vashon drift, Pleistocene, British Columbia: Clapp, 1.99. 
Vashon epoch (glacial), Pleistocene, Washington: Bretz, 101.

Vedder greenstone, Carboniferous, Washington, British Columbia: Daly, 278.

Vermejo formation, Cretaceous, Colorado and New Mexico; Knowlton, 632.

Vermejo formation, Tertiary, Colorado and New Mexico: Lee, 671.

Vermilion Cliff sandstone, Triassic, Utah: Lawson, 663 .

Vernon shale, Silurian, New York: Grabau, 427.

Vicksburg group, Oligocene, Florida: Matson and Sanford, 768 ; Sellards and Gunter, 1038

Wapiabi shales, Cretaceous, Alberta : Malcolm, 741 .

Wapiti River sandstone, Cretaceous, Alberta: Malcolm, $\mathbf{7 4 1 .}$

Wapiti River sandstones, Cretaceous, British Columbia: Galloway, 394.

Wardner formation, Mississippian, British Columbia: Schofield, 1020.

Wark gneiss, Mesozoic, British Columbia: Clapp, 199.

Wasatch formation, Tertiary, Colorado: Woodruff, 1325 .

Wasatch limestone, Utah: Hintze, 507.

Washington fire clay shale, Carboniferous, West Virginia: Fennen and Reger, 479; Kr'ebs and Teets, 640.

Washington sindstone, Carboniferous, West Virginia: Hernnen and Reger, 479.

Washington (lower) limestone, Carboniferdus, West Virginia: Hennen and Reger, 479.

Washington (upper) limestone, Carboniferous, West Virginia: Hennen and Reger, 479 .

Waterton formation, pre-Devonian, Montana and British Columbia: Daly, 278.

Waynesburg limestone, Carboniferous, West Virginla : IIennen and Reger, 479.

Waynesburg sandstone, Carboniferous, West Virginia: Hennen and Reger, 479 ; Krebs and Teets, 640.

Weber quartzite, Pennsylvanian, Utah: Hintze, 507.

Wells formation, Pennsylvanian, Idaho: Schultz and Richards, 1030.

Wells formation, Pennsylvanian, Utah : Richardson, 975 .

Wheaton River volcanics, Tertiary or Pleistocene, British Columbia: Cairnes, 158.

Whillpool quartzite, Silurian, New York Grabau, 427.

Whillpool sandstone, New York and Ontario: Taylor, 1149.

Whirlpool sandstone member, Silurian, New York: Kindle and Taylor, 619.

Whitehorse sandstone member, I'ermian, Oklahoma : Snider, 1078.
White River beds, Tertiary, North Dakota: Leonard, 678.

White River formation, Oligocene, South Dakota : Winchester, 1313.

Whitewater series, pre-Cambrian, Ontario: Collins, 247.

Wichita formation, Permian, Texas, Gordon, 416.

Wicomico formation, Pleistocene, Virginia : Sanford, 1004

Wigwam formation, Cambrian, Montana and British Columbia: Daly, 278.

Willow Creek beds, Cretaceous, Alberta: Malcolm, 741 .

Windsor series, Carboniferous, Nova Scotia : Bell, 64.

Windsor series, Mississippian, Nova Scotia: Hyde, 543.

Winifrede (lower) sandstone, Carboniferous, West Virginta: Krebs and 'Teets, 640.

Winifrede (upper) sandstone, Carboniferous, West Virginia: Krebs and Teets, 640.

Winnipeg sandstone, Ordovician, Manitoba : Malcolm, 741. Wallace, 1230.

Winnipegosan, Devonian, Manitoba: Dowling, 326; Malcolm, 741.

Winnipegosan dolomite, Devonian, Manltoba: MacLean, 736 .

Wisconsin drift, Quaternary: Deeley, 304.

Wisconsin stage, Quaternary, New York: Kindle and 'Taylor', 619.

Wolcott limestone member, Silurian, New York: Kindle and 'Taylor', 619.

Wolf formation, pre-Cambrian, Idaho and British Columbia: Daly, 278.

Wolsey shale, Cambrian, Montana: Knopf, 626.

Woodbury shales, Cretaceous, Iowa: Keyes, 609.

Woodmont shale, Devonian, Maryland: Swartz, 1137.

Woodside shale, Triassic, Idaho: Schultz and Richards, 1030.

Woodward formation, Fermian, Oklahoma : Snider, 1078.

Worm Creek quartzite member, Cambrian, Utah: Richardson, 975.

Yaklma basalt, Miocene, Washington: Waring, 1232.

Yakinikak limestone, Mississippian, Montana: Daly, 278.

Yarmouth (?) soil, Quaternary, Illinois : Shaw and Savage, 1042.

Yarmonth soil and loess, Quaternary: Deeley, 304.

Iogo limestone, Cambrian, Montana : Knopf, 626.

Yonkers gneiss, pre-Cambrian, New York: Kemp, 588.

Forktown formation, Miocene, Virginia : Sanford, 1004. 